UNIVERSIDADE DE SÃO PAULO

Renata Cristina do Nascimento Antão

\title{
O DIREITO À EDUCAÇÃO DO ADOLESCENTE EM SITUAÇÃO DE PRIVAÇÃO DE LIBERDADE
}

Mestrado em Direito

São Paulo, 2013 


\title{
O DIREITO À EDUCAÇÃO DO ADOLESCENTE EM SITUAÇÃO DE PRIVAÇÃO DE LIBERDADE
}

\author{
Dissertação de Mestrado apresentada ao \\ Programa de Pós-graduação Strictu Sensu da \\ Faculdade de Direito da Universidade de São \\ Paulo. \\ Orientadora Professora Associada Nina \\ Beatriz Stocco Ranieri
}

Faculdade de Direito da Universidade de São Paulo - USP

Programa de Direitos Humanos

São Paulo, 2013 
Banca Examinadora 


\section{Agradecimentos}

À minha mãe Luzia, pelo amor e pelo exemplo de força, ao meu pai $\mathbf{L u i z}$, pelo exemplo de perseverança.

À minha tia e madrinha Maria Antonia, pelo estímulo aos estudos.

Aos três pelo apoio emocional e material, diário e incondicional e a minha família pela alegria da vida: Elza, Yuri, Gustavo e Jonas.

Agradeço a minha professora e orientadora, Nina Beatriz Ranieri Stocco, pela confiança e oportunidade, por aceitar me orientar recém saída da graduação e pelo exemplo de coerência que representa na área do direito à educação. Agradeço também às professoras Eunice Prudente e Monica Caggiano, pela participação em meu exame de qualificação, cujas contribuições trouxeram mais grandeza a este estudo.

A todos aqueles que passaram pelo Escritório Modelo Dom Paulo Evaristo Arns PUC/SP, que entre muito trabalho e indignações da luta diária pela afirmação de direitos, insistem, buscando um país melhor: Anna Claudia Vazzoler, Sabrina Durigon, Karen Cruz, Rose dos Santos, Fernanda Carpanelli, Carla Paixão e tantos outros colegas e estagiários que por lá passaram.

Às amigas de trabalho que se transformaram em companheiras da vida e da luta: Delana Corazza e Mariana Lins - Não nos afastemos muito, vamos de mãos dadas!

Aos colegas Defensores (populares ou não), aos participantes do NADIR, em especial à professora Ana Lucia Pastore, aos amigos do Centro Gaspar Garcia de Direitos Humanos, aos movimentos sociais e a todos aqueles que de alguma forma contribuíram para esta dissertação.

Pelos almoços, cafés e dramas compartilhados: Carolina Nascimento, Cibele Dione, Felipe Ocanha e Antonio Barbosa.

A todos aquelas crianças e jovens que excluídos por um perverso sistema, vendo seus sonhos e brincadeiras se transformarem pela dura realidade, dedico este trabalho. 
"Todos estavam silenciosos. Um operário que vinha pela rua, vendo a aglomeração dos meninos na praça, veio para o lado deles. E ficou também parado, escutando a velha música. Então a luz da lua se estendeu sobre todos, as estrelas brilharam ainda mais no céu, o mar ficou de todo manso (talvez que Iemanjá tivesse vindo também ouvir a música) e a cidade era como que um grande carrossel onde giravam em invisíveis cavalos os Capitães da Areia. Neste momento de música eles sentiram-se donos da cidade. E amaram-se uns aos outros, se sentiram irmãos porque eram todos eles sem carinho e sem conforto e agora tinham o carinho e o conforto da música." 


\section{RESUMO}

ANTÃO, Renata Cristina do Nascimento. O direito à educação do adolescente em situação de privação de liberdade. 2012. 228 p. Dissertação (Mestrado). Faculdade de Direito, Universidade de São Paulo, 2012.

A educação, tida como direito fundamental, ou seja, um direito público subjetivo, de aplicabilidade imediata, nos estabelecimentos de privação de liberdade muitas vezes acaba se limitando a figurar como uma garantia simbólica. Muitos dos adolescentes em conflito com a lei entram no sistema punitivo juvenil apresentando baixo grau de escolaridade, e, ao longo do cumprimento das medidas socioeducativas, permanecem apresentando déficit no ensino e com atitudes aquém da proposta ressocializadora e educacional da medida punitiva.

Sendo a educação um direito de todos, ela deve ser efetivada e assegurada sempre, principalmente porque a educação, em seu sentido amplo, possibilita a resignificação do jovem em conflito com a lei.

O presente estudo pretendeu analisar o direito à educação do adolescente em privação de liberdade, sua garantia e aplicação nos estabelecimentos de privação de liberdade nos quais são cumpridas medidas socioeducativas de internação e semiliberdade.

Para tanto, foi sistematizada e analisada a legislação referente ao direito à educação, ao direito da criança e do adolescente, e mais especificamente a juventude em conflito com a lei, para assim, confrontarmos o direito formulado em nossa legislação e literatura acadêmico-doutrinária a jurisprudência relativa à aplicação deste direito.

Palavras-chave: direito à educação, medida socioeducativa, conflito com a lei. 


\begin{abstract}
ANTÃO, Renata Cristina do Nascimento. The right to education of adolescents in situations of deprivation of freedom. 2012. 228 p. Thesis (Master). Faculty of Law, University of São Paulo, 2012.
\end{abstract}

Education is regarded as a fundamental right, ie a public right of immediate applicability. Establishments of deprivation of freedom, it often ends up limited to feature as guarantee symbolic. Many adolescents in conflict with the law go into punitive juvenile system presenting low educational level, and along the fulfillment of the socioeducational measures, they still present educational deficits and actions behind the proposal of re-socialize and educate of punitive measure.

Being education a right of everyone, it should be carried out and guaranteed always mainly because education in its widest sense, allows resignification of the youth in conflict with law. The aim of this study is to examine the right to education of adolescents deprived of freedom, security and application in their establishments of deprivation of liberty in which educational measures are met hospitalization and semifreedom.

Therefore, we analyzed the legislation concerning the right to education, the right of children and adolescents, and more specifically the youth in conflict with the law, thus confronting the law formulated in our legislation and academic literature-doctrinal rulings concerning under that law.

Keywords: Right to education, socioeducative measure, conflict with the law 


\section{LISTA DE SIGLAS}

CIDH - Comissão Interamericana de Direitos Humanos

CNE - Conselho Nacional de Educação

CNJ - Conselho Nacional de Justiça

ECA - Estatuto da Criança e do Adolescente

FEBEM - Fundação Estadual do Bem-Estar do Menor

IBGE - Instituto Brasileiro de Geografia e Estatística

LDB - Lei de Diretrizes e Bases da Educação

LEP - Lei de Execução Penal

MEC - Ministério da Educação

MSE - Medida Socioeducativa

OEA - Organização dos Estados Americanos

ONU - Organização das Nações Unidas

PEC - Projeto Educação e Cidadania

PEDH-SP - Programa Estadual de Direitos Humanos do Estado de São Paulo

PIA - Plano Individual de Atendimento

PIA - Plano Individual de Atendimento

PIDESC - Pacto Internacional sobre Direitos Econômicos, Sociais e Culturais

PNDH - Programa Nacional de Direitos Humanos

PNE - Plano Nacional de Educação

PRTE - Projeto Revitalizando a Trajetória Escolar

SINASE - Sistema Nacional de Atendimento Socioeducativo

UNESCO - Organização das Nações Unidas para a Educação, a Ciência e a Cultura VIJ - Varas de Infância e Juventude 


\section{REFLEXÕES INICIAIS}

\section{I - O DIREITO FUNDAMENTAL À EDUCAÇÃO: DIREITO SOCIAL FUNDAMENTAL AO ESTADO DEMOCRÁTICO DE DIREITO}

\section{O Estado Democrático de Direito e os Direitos Humanos}

a. Conceitos e definições preliminares

b. Os Direitos Humanos: Fundamentais e Sociais

2. O direito fundamental à educação
a. Definição e fundamento
b. Educação e ensino
c. Acesso à educação

3. Fontes Nacionais do Direito Educacional
a. Constituição da República Federativa do Brasil
b. Lei de Diretrizes e Bases da Educação Nacional
c. Plano Nacional de Educação
d. Conselho Nacional de Educação

4. Tratados e Declarações e o Direito à Educação

a. Declaração Universal de Direitos Humanos

i. Um "Direito Novo" e sua lógica

ii. A Declaração e o direito à educação

b. Pacto Internacional dos Direitos Econômicos, Sociais e Culturais

c. Declaração de Hamburgo

d. Declaração Mundial sobre Educação para todos

5. Políticas públicas educacionais e jurisprudência

\section{II - A CRIANÇA E O ADOLESCENTE}

\section{Direito da Criança e do Adolescente}

a. Concepções que orientam o direito da criança e do adolescente

i. Escorço histórico da infância no Brasil

ii. Definição de Criança e Adolescente 
b. Doutrina do respeito à peculiar condição de pessoa em desenvolvimento

c. Doutrina da prioridade absoluta

d. Doutrina da proteção integral

e. Direitos fundamentais especiais de criança e adolescente

i. Direito à educação

ii. Direito à liberdade (tutela especial da liberdade)

iii. Outros direitos individuais especiais da criança e do adolescente autor de crime.

\section{O adolescente em conflito com a lei}

a. O perfil do adolescente autor de infração

b. Trajetória de vitimização do adolescente autor de infração

\section{III - A LEI, A INFRAÇÃO E A PUNIÇÃO}

\section{A medida socioeducativa}

a. Definição

b. Tipos de medidas socioeducativas

c. A eficácia das medidas socioeducativas

2. O sistema de cumprimento de medidas socioeducativas

a. O espaço prisional destinado ao cumprimento de medidas socioeducativas de internação

b. O sistema de cumprimento de medida socioeducativa de internação

c. O Centro de Atendimento Socioeducativo ao Adolescente - Fundação CASA-SP

d. O fornecimento educacional na Fundação CASA: O Projeto Educação e Cidadania e outros projetos

\section{IV - DIREITO À EDUCAÇÃO DO ADOLESCENTE EM SITUAÇÃO DE PRIVAÇÃO DE LIBERDADE}

1. Fontes do direito à educação em situações de privação de liberdade

a. Legislação Nacional

i. Programa Nacional de Direitos Humanos

ii. Programa Estadual de Direitos Humanos do Estado de São Paulo

iii. Estatuto da Criança e do Adolescente 
iv. Resolução $n^{\circ} 46$ de 1996, do Conselho Nacional dos Direitos da Criança e do Adolescente

v. Resolução ${ }^{\circ} 02$ de 2010, do Conselho Nacional de Educação

b. Legislação Internacional

i. A Organização das Nações Unidas para a Educação a Ciência e a Cultura e seus desafios e estratégias para a educação

ii. Convenção das Nações Unidas sobre os Direitos das Crianças

iii. Convenção Relativa à Luta contra a Discriminação no Campo do Ensino.

iv. Resolução no 40/33 da Assembleia Geral, de 29.11.85 - Regras de Beijing

v. Regras Mínimas das Nações Unidas para a Elaboração de Medidas não Privativas de Liberdade - Regras de Tóquio

vi. Regras mínimas para o tratamento de prisioneiros

2. O fornecimento educacional do adolescente em conflito com a lei e a visão do Judiciário

\section{CONSIDERAÇÕES FINAIS}

\section{REFERÊNCIAS BIBLIOGRAFICAS}




\section{REFLEXÕES INICIAIS}

\section{A escolha do direito à educação juvenil em ambiente de privação de liberdade}

O direito à educação é um direito fundamental, público e subjetivo, que leva o individuo a desenvolver, com autonomia, as suas potencialidades como ser humano. Tanto que a Constituição estabelece em seu art. 205 que o direito à educação é "direito de todos e dever do Estado e da família".

Ao analisá-lo a partir do enfoque do adolescente, esta fundamentabilidade se amplia, pois sob o manto do Sistema Constitucional Especial de Proteção aos Direitos Fundamentais da Criança e do Adolescente, instituído pela Constituição Federal de 1988, distinguem-se as crianças e adolescentes dos outros grupos de indivíduos, considerando que os primeiros são seres em desenvolvimento que merecem tutela diferenciada e prioridade absoluta na efetivação de direitos. LIBERATI $^{1}$ entende por "absoluta prioridade" que a criança e o adolescente estejam "em primeiro lugar na escala de preocupação dos governantes", e, desta forma:

"[...] na área administrativa, enquanto não existirem creches, escolas, postos de saúde, atendimento preventivo e emergencial às gestantes, condições dignas de moradia e trabalho, não se deveriam asfaltar ruas, construir praças, sambódromos, monumentos artísticos, etc., porque a vida, a saúde, o lar, a prevenção de doenças são mais importantes que as obras de concreto que ficam para demonstrar o poder do governante".

O Sistema Constitucional Especial de Proteção deriva do disposto nos artigos 226, 227, 228 e 229 da Constituição Federal, tendo como noção fundamental e fundante a peculiar condição de seres humanos em processo de desenvolvimento ${ }^{2}$.

Tal previsão também se encontra no Estatuto da Criança e do Adolescente (Lei 8.069, de 13 de julho de 1990) que substituiu o antigo Código de Menores (Lei 6.697, de 10 de outubro de 1979), contemplando os seus direitos, regulamentando o artigo 227 da CF/88. O ECA, além de expressar resoluções da Convenção Internacional dos Direitos da Criança de 1989, proclamando uma doutrina de proteção integral, é claro ao dispor que a criança e o adolescente devem ter preferência na formulação e na execução das políticas sociais ${ }^{3}$.

\footnotetext{
${ }^{1}$ LIBERATI, Wilson Donizeti. "Conteúdo material do direito à educação (208-260)". In. LIBERATI, Wilson Donizeti (org.). Direito à educação: Uma questão de justiça. São Paulo: Malheiros, 2004. p. 1819).

${ }^{2}$ MACHADO, Martha de Toledo. A proteção constitucional de crianças e adolescentes e os direitos humanos. São Paulo: Manole, 2003.p. 135.

${ }^{3}$ BRASIL, 1990, art. $4^{\circ}$, alínea b.
} 
Muito se fala sobre os avanços da educação no Brasil: as reduções de taxas de analfabetismo, o crescimento da escolaridade média dos brasileiros, as expectativas sobre a ampliação do acesso e da qualidade na educação. Porém, pouco ou quase nada se fala sobre os avanços neste campo àqueles que se encontram cumprindo medidas socioeducativas de privação total ou parcial de liberdade sobre a tutela estatal.

A opção pelo estudo do direito à educação do adolescente que cumpre medida privativa de liberdade em razão de ato infracional justifica-se por ser esta uma questão não apenas de política educacional, mas de segurança pública, que exige maior compreensão a partir da análise sistemática da legislação e jurisprudência. O problema se amplia ao confrontarmos o direito à educação e a punição pelo ato infracional, para a verificação de desrespeito, ou não, eventual à sua garantia e aplicação.

Segundo dados oficiais, o número de adolescentes que cumpre medida socioeducativa em unidades de internação da Fundação Casa cresceu $18 \%$ entre agosto de 2010 e setembro de 2011, isto é, em pouco mais de um ano, esta população saltou de 484 para 572. Tais dados nos mostram a relevância da reflexão e análise acerca da educação fornecida nestes estabelecimentos.

Em nossa pesquisa, analisaremos, especificamente, a Fundação Centro de Atendimento Socioeducativo ao Adolescente (CASA) - instituição vinculada à Secretaria de Estado da Justiça e da Defesa da Cidadania do Estado de São Paulo ${ }^{4}$-, e sua relação de parceria e gestão compartilhada do fornecimento educacional com a Secretaria de Educação do Estado de São Paulo ${ }^{5}$ - responsável prioritário pelo fornecimento do ensino fundamental e médio no estado de São Paulo, inclusive nos estabelecimentos de cumprimento de medida socioeducativa de privação de liberdade.

\section{A doutrina especial de proteção integral e prioridade absoluta no Brasil}

A infância passou a ser identificada no tecido social $^{6}$ somente a partir do final do século XVII e início do século XVIII. No Brasil, a chamada doutrina menorista inaugura o período no qual os olhos do legislador se voltam para a criança, até então considerada objeto de direito, invisível à sociedade. Assim, com a promulgação do Código de Menores $^{7}$, em 1927, as crianças passam a ter alguns direitos e deveres

\footnotetext{
${ }^{4}$ http://www.justica.sp. gov.br/novo_site/ Acesso em: 10 de abril de 2012.

${ }^{5}$ http://www.educacao.sp. gov.br/ Acesso em: 10 de abril de 2012.

${ }^{6}$ MACHADO, Martha de Toledo. A proteção constitucional de crianças e adolescentes e os direitos humanos. São Paulo: Manole, 2003.p. 29.

${ }^{7}$ Decreto no $17.943-\mathrm{A}$ de 12 de outubro de 1927.
} 
legislados, como a proibição do trabalho $^{8}$ para os menores de 12 anos, bem como a adoção de medidas assistencialistas e protecionistas ao "menor" abandonado ou delinquente. $\mathrm{O}$ termo delinquência e sua noção acabam por adjetivar e estigmatizar o indivíduo. Assim, a criminologia crítica atual busca compreender a infração como um fenômeno transitório na vida do indivíduo, tirando o estigma do "delinquente". Porém, como a bibliografia internacional especializada utiliza o termo "delinquência juvenil" (juvenile delinquency) esta pode vir a ser utilizada ao longo do trabalho.

Crianças e adolescentes se tornam objeto da atenção de médicos, psicólogos, pedagogos e juristas que institucionalizaram a figura do menor abandonado através de casas públicas de custódia, nas quais era aplicado o modelo compaixãorepressão dominante na doutrina da situação irregular.

O Código de Menores deu suporte à chamada “escola menorista”, que considerava a criança pobre e desvalida e a criança autora de infração ou crime da mesma forma. Esta clara confusão conceitual, de forte influência positivista e determinista, acabou por permitir sérias violações aos direitos fundamentais tanto de crianças carentes quanto de crianças delinquentes; de modo que o binômio, historicamente construído, criança carente/delinquente, ou infância desviante, acabou por marcar o Estado, o Direito e todas as instâncias criadas para aplicação desta doutrina menorista, doutrina da situação irregular. Na Doutrina da situação irregular havia clara diferenciação entre os menores regulares, ou seja, aqueles nascidos em famílias com posses, podendo usufruir de educação, saúde e todo tipo de direito; e os menores irregulares, provenientes de famílias pobres, órfãos, ou que haviam cometido algum tipo de delito. Este segundo "tipo de menor" recebia tratamento jurídico diferenciado, podendo ser retirados arbitrariamente do convívio familiar, sendo levados a unidades de internação tanto órfãos ou crianças abandonadas, quanto as que cometiam crimes.

Foi a doutrina da proteção integral, sedimentada pela Convenção Internacional dos Direitos da Criança da ONU, de 1989, que rompeu com a doutrina menorista, fazendo, então, com que os "menores" fossem vistos como crianças e

\footnotetext{
${ }^{8}$ Art. 101. é prohibido em todo o territorio da Republica o trabalho nos menores de 12 annos. Art. 102. Igualmente não se póde ocupar a maiores dessa idade que contem menos de 14 annos. e que não tenham completando sua instrucção primaria. Todavia. a autoridade competente poderá autorizar o trabalho destes, quando o considere indispensavel para a subsistencia dos mesmos ou de seus paes ou irmãos, comtanto que recebam a instrucção escolar, que lhes seja possível.
} 
adolescentes sujeitos de direitos ${ }^{9}$ amparados por um sistema de proteção. O qual acaba por autorizar uma aparente quebra do princípio da igualdade, possibilitando uma diferenciação positiva feita às crianças e adolescentes, visto estes serem "portadores de uma desigualdade de fato" e permitindo-lhes atingir uma "igualdade jurídica material e não meramente formal" $" 10$.

A Constituição Federal do Brasil e o Estatuto da Criança e do Adolescente vêm, assim, romper com a antiga doutrina da situação irregular e sua nefasta tradição autoritária e excludente, que tinha na confusão conceitual entre "infância carente e infância delinquente" um instrumento jurídico extremamente poderoso à "manutenção do status quo e das desigualdades sociais" $" 11$.

\section{3. $O$ adolescente em conflito com a lei e o fornecimento educacional nos espaços de privação de liberdade}

No direito penal juvenil, a conduta análoga a crime ou contravenção penal praticada por adolescente é chamada ato infracional. O Sistema de Proteção Integral permite que o adolescente infrator seja sujeito de medida socioeducativa, prevista nos artigos 103, 104 e 212 do Estatuto da Criança e do Adolescente. As sanções previstas pelo ECA vão da advertência à aplicação de medidas socioeducativas (obrigação de reparar o dano, prestação de serviços à comunidade, liberdade assistida, semiliberdade e até internação). O Estatuto da Criança e do Adolescente ao tratar dos objetivos da ressocialização ${ }^{12}$ e educação dos adolescentes em conflito com a lei (que praticaram atos infracionais) $)^{13}$ é extremamente avançado, prevendo a aplicação de medidas

\footnotetext{
9 “(...) Crianças e adolescentes merecem, e receberam, do ordenamento brasileiro esse tratamento mais abrangente e efetivo porque, à sua condição de seres diversos dos adultos, soma-se a maior vulnerabilidade deles em relação aos seres humanos adultos.

É esta vulnerabilidade que é a noção distintiva fundamental, sob a ótica do estabelecimento de um sistema especial de proteção, eis que distingue crianças e adolescentes de outros grupos de seres humanos simplesmente diversos da noção do homo médio." MACHADO, Martha de Toledo. A proteção constitucional de crianças e adolescentes e os direitos humanos. São Paulo: Manole, 2003. p. 119.

${ }^{10}$ MACHADO, Martha de Toledo. A proteção constitucional de crianças e adolescentes e os direitos humanos. São Paulo: Manole, 2003. p. 119.

${ }^{11}$ MACHADO, Martha de Toledo. A proteção constitucional de crianças e adolescentes e os direitos humanos. São Paulo: Manole, 2003.p. 54.

${ }^{12}$ Há quem diga que estas visam "favorecer a reintegração e reeducação do adolescente", mas tal discurso não é aceito na criminologia crítica, já que o prefixo "re" tem conotação de repetição e muitas destas crianças e adolescentes em conflito com a lei, na maioria das vezes, não foram anteriormente nem integradas, nem educadas.

${ }^{13}$ A opção por tais expressões se dá "por apresentarem uma circunstância de vida e não uma categoria valorativa" como ocorre com a utilização do termo 'adolescente infrator', que torna o "o adjetivo mais importante que o substantivo, imprimindo um estigma irremovível” (VOLPI, 2001, p. 21)
} 
socioeducativas que devem buscar esta socialização e habilitação para a vida em sociedade.

As medidas socioeducativas, previstas no artigo 212 do Estatuto da Criança e do Adolescente, visam punir e educar. A educação e seu fornecimento dentro dos estabelecimentos de cumprimento destas medidas é, assim, de extrema importância, devendo estar comprometida com valores e com a "vocação ontológica do homem" de ser sujeito, tal qual nos ensina Paulo Freire, auxiliando estes adolescentes na construção de novos caminhos, e contribuindo para a "construção da autonomia dos sujeitos de modo que eles possam visualizar alternativas para a própria vida, inclusive - e de preferência, fora do crime." ${ }^{14}$.

\section{Justificativa da escolha}

$\mathrm{O}$ interesse por este tema de pesquisa foi motivado por anseios em investigar durante o trabalho de conclusão de curso (tese de láurea) a questão educacional dentro dos encarceramentos femininos. $\mathrm{O}$ trabalho desenvolvido voltou-se a análise de relatórios e pesquisas realizadas por instituições da sociedade civil e órgãos governamentais, como a Secretaria Especial de Políticas para as Mulheres ${ }^{15}$, os quais a partir de visitas aos estados obtiveram um diagnóstico a respeito da oferta escolar existente nas prisões e de suas principais fragilidades.

Participando do Laboratório de Ciências Criminais do Instituto Brasileiro de Ciências Criminais (IBCCRIM) e das diversas discussões relacionadas às condições dos estabelecimentos prisionais, questões de criminologia e política criminal foi possível analisar dados, participar de debates e mesas de estudo, verificando assim, que a realidade dos estabelecimentos de privação de liberdade em muito se difere da disposta no texto legal.

Outro fator que levou à investigação da educação em estabelecimentos de privação de liberdade foi o exercício profissional enquanto professora de desenvolvimento infantil e acompanhamento das ações socioeducativas desenvolvidas através do Programa Escola da Família. Vivências que mostraram que muitos dos jovens e adultos que cumprem penas privativas de liberdade tiveram itinerários de vida

\footnotetext{
${ }^{14}$ MOREIRA, Fábio Aparecido. "A política de Educação de Jovens e Adultos em Regimes de Privação de Liberdade no Estado de São Paulo”. Dissertação de Mestrado. São Paulo, 2007.p. 39.

${ }^{15}$ Brasil. Presidência da República. Secretaria Especial de Políticas para as Mulheres. Grupo de Trabalho Interministerial - Reorganização e reformulação do Sistema Prisional Feminino - 2008. Brasília: 2008. P. $70-72$
} 
escolar interrompidos por problemas sociais constantes como desagregação familiar, drogas, violência, falta de moradia entre outras causas que fogem do nosso entendimento, não podendo a privação de liberdade espoliá-los novamente.

Em todo esse contexto, pareceu-nos bastante relevante aprofundar estudos sobre a educação e sua efetivação nos estabelecimentos prisionais, visto haver um grande abismo entre os direitos constitucionalmente elencados (no presente caso o direito à educação) e a realidade do encarceramento, principalmente quando tratamos de jovens, cuja vida está apenas começando, havendo inúmeras possibilidades de mudança e resignificação.

\section{Justificativa da importância do tema}

A educação, direito de todos e dever do Estado e da família, por visar o pleno desenvolvimento da pessoa, o seu preparo para o exercício da cidadania e a sua qualificação para o trabalho, instrumentaliza o indivíduo na busca e aquisição dos demais direitos. $\mathrm{O}$ direito à educação, dentro da sua fundamentabilidade, faz da escola, na maioria das vezes, prediletora de destinos, pois "mais do que uma exigência contemporânea ligada aos processos produtivos e de inserção profissional" ela "responde a valores da cidadania social e política"16.

O direito à educação é o "campo privilegiado de realização dos direitos fundamentais, dadas as suas repercussões na vida do indivíduo, da sociedade e do Estado, e da pluralidade de direitos que dele dependem"17.

Quando tratamos da educação no espaço prisional, nos referimos aos socialmente excluídos, tanto que analisando a trajetória daqueles que se encontram cumprindo medida socioeducativa restritiva de liberdade, percebemos que os percursos escolares destes foram e são extremamente deficitários quando não inexistentes ${ }^{18}$.

Tendo a educação como direito fundamental, e visto o fundamento da pena não ser apenas a punição, mas a resocialização do indivíduo, faz-se necessário pensar na educação dos adolescentes que cumprem medidas judiciais de privação de liberdade,

\footnotetext{
${ }^{16}$ CURY, Carlos Roberto J., "Direito à educação: direito à igualdade, direito à diferença”, Cadernos de Pesquisa, São Paulo, n.116, Julho, 2002. Disponível em: http://www.scielo.br/pdf/cp/n116/14405.pdf. Acesso em: 10 Abril. 2012.

${ }^{17}$ RANIERI Nina Beatriz Stocco, "O Estado Democrático de Direito e o Sentido da Exigência de Preparo da Pessoa para o Exercício da Cidadania pela Via da Educação", tese apresentada à Faculdade de Direito da Universidade de São Paulo, para obtenção de título de livre docente junto ao Departamento de Direito do Estado, São Paulo, 2009. p. 29.

${ }^{18} \mathrm{http} / / /$ www.fundacaocasa.sp. gov.br/index.php/superintendencia-pedagogica - Acesso em 23.03.2012.
} 
para que estas não se deem apenas no tempo, mas conforme dispositivos legais constitucionais e internacionais de direitos humanos.

Cabe mencionar que no que toca ao tema da educação do adolescente em conflito com a lei, privado de liberdade, há vasta produção acadêmica ligada, entre outros, à Faculdade de Educação e ao Instituto de Psicologia da USP; entretanto, são escassas tais pesquisas no âmbito jurídico, e quando existentes são impregnadas da doutrina menorista. Demonstramos, assim, a importância que a presente pesquisa trará para a garantia desse direito.

\section{Objetivos}

\subsection{Objetivo Geral da pesquisa}

(i) Explorar e desenvolver uma análise jurídica e jurisprudencial sobre o direito à educação, com o recorte do adolescente que cumpre medida socioeducativa de privação de liberdade;

(ii) Sistematizar e analisar a legislação e jurisprudência referente à garantia do direito à educação nos estabelecimentos de privação de liberdade juvenis, no estado de São Paulo, e sua efetivação;

(iii) verificar como o ensino público é ofertado nestas instituições (Estudo de caso da Fundação CASA-SP), delimitando o tipo de ensino realizado;

(iv) verificar a observância e aplicabilidade, pelas instituições (Fundação CASA-SP), do direito à educação, bem como dos direitos e garantias especiais da criança e do adolescente, e princípios constitucionais a ele relacionados.

\subsection{Objetivo Específico}

(i) Esquematizar e analisar a legislação (leis, decretos, regulamentos e normativas) referente à oferta educacional nos estabelecimentos de cumprimento de medida socioeducativa em São Paulo (Centro de Atendimento Socioeducativo ao Adolescente - Fundação CASA-SP);

(ii) Verificar o ensino público ofertado no Centro de Atendimento Socioeducativo ao Adolescente - Fundação CASA-SP;

(iii) Relacionar, sistematizar e analisar a legislação existente (tratados, protocolos, leis, decretos e resoluções) referente à oferta educacional aos adolescentes privados de liberdade em razão de cometimento de ato infracional; 
(iv) Analisar a jurisprudência do Tribunal de Justiça de São Paulo sobre o tema, sistematizá-la e verificar como a legislação foi interpretada e aplicada, tendo como instrumento súmulas e acórdãos. A análise jurisprudencial das demandas educacionais referentes ao espaço de privação de liberdade se dará a partir da vigência do Estatuto da Criança e do Adolescente, ano de $1991^{19}$, até o ano de 2011. Tal corte temporal, que abarca os 20 anos de vigência do ECA, se faz por o considerarmos um importante ordenador jurídico para a garantia e defesa dos direitos da infância e juventude. Insta salientar que tal delimitação temporal é necessária pois abrange não só o tempo suficiente para a criação do aparato jurídico-educacional do sistema de proteção à criança e ao adolescente, mas também à mudança ocorrida com os 06 anos de implantação da Fundação CASA e seu novo modelo de intervenção em substituição ao antigo modelo vigente na FEBEM. A análise buscará assim, investigar procedimentos de realização, concretização e cumprimento das normas constitucionais e ocorrerá em duas etapas. A primeira, formal, em que as decisões coletadas serão sistematizadas dentro dos seguintes tópicos: 1. Número do processo; 2. Natureza do recurso; 3. Data do julgamento; 4. Categorias; 5. Temas; 6. Origem: Comarca originária do processo; 7. Apelante/Recorrente: os nomes dos autores que recorreram da decisão anterior; 8. Apelados/Recorridos: os nomes dos autores que foram apelados ou recorridos para a solução do litígio; 9. Câmara: Sessão onde ocorreu o julgamento; 10. Votação: se unânime ou maioria dos votos; 11. Resultado: se o recurso foi provido, não provido, parcialmente provido, recurso extinto; 12. Relator: nome do desembargador relator da decisão; e 13. Localização da ementa e do acórdão: indicando a origem do acesso do material. Após a sistematização, a segunda etapa, que será material, se dará através do seguinte roteiro de pesquisa: a. Contexto - Em que consistiu o caso e quais os fatos? Quais os problemas políticos sociais e humanos suscitados? Qual o contexto legislativo constitucional e ordinário? b. Texto e significado da norma - Quais os sentidos interpretativos que podem ser atribuídos ao anunciado da disposição constitucional e ordinária em referência (origem, teleologia, história, interpretação gramatical e interpretação sistêmica do texto)? c. Controvérsias constitucionais - quais as principais controvérsias suscitadas pela normatização? d. Argumentação das partes e dos

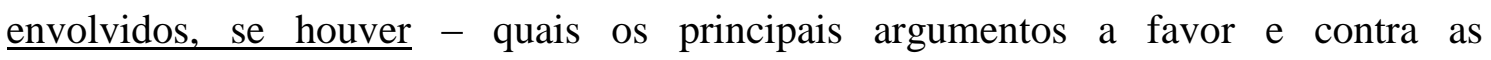
controvérsias? Quais as teses levantadas? e. Argumentação do Tribunal - Quais as

\footnotetext{
${ }^{19}$ Promulgado em julho de 1990, e publicado D.O.U. 16.7.1990 e retificado no D.O.U de 27.9.1990, entrando em vigor 90 (noventa) dias após sua publicação (art. 266 da Lei 8.069/90).
} 
razões constitucionais da tese vencedora? E as do(s) voto(s) dissidentes? f. Decisão do Tribunal - Qual a norma de decisão? Qual(is) o(s) fundamento(s) do acórdão? O resultado final tem força racional a ponto de ser facilmente aceito pela sociedade? Quais os seus benefícios sociais? Qual a sua repercussão jurídica?

Serão igualmente analisadas as estruturas e articulações existentes entre órgãos envolvidos com a educação juvenil em estabelecimentos de privação de liberdade, quais sejam: o Conselho Nacional de Educação, a Secretaria Estadual de Educação e a Fundação CASA; analisando suas competências e atribuições. Isto porque, sendo a Secretaria de Educação do Estado de São Paulo responsável prioritário pelo fornecimento do ensino fundamental e médio no estado de São Paulo, e sendo a Fundação Centro de Atendimento Socioeducativo ao Adolescente (CASA) a instituição responsável pela tutela dos adolescentes que lá cumprem medida socioeducativa de privação de liberdade, faz-se necessário analisar dentro das competências desses órgãos suas atribuições e limites na oferta do ensino; bem como a evolução da proteção e promoção do direito à educação ao adolescente que se encontra privado de liberdade, visualizando possíveis lacunas, a fim de delinear novas propostas para efetivação da oferta educacional nos estabelecimentos de privação de liberdade destinados ao cumprimento de medidas socioeducativas.

\section{Desenvolvimento}

A sistematização e análise de dados ocorreram em continuidade aos estudos e pesquisas iniciados ainda na graduação de Direito com a temática da educação prisional, fornecendo subsídios para a dissertação de mestrado na Faculdade de Direito da USP. O trabalho de pesquisa teve seu foco prioritário no levantamento bibliográfico e legislativo de maneira a agregar à bibliografia específica, voltada ao tema central da pesquisa. Para tanto, foram usadas como fontes, as Bibliotecas da Universidade de São Paulo (USP), da Pontifícia Universidade Católica de São Paulo (PUC-SP), e do Instituto Brasileiro de Ciências Criminais (IBCCRIM), a internet (sítios eletrônicos do STJ, do STF e do TJ-SP), resenhas críticas e artigos, através de revistas especializadas como, por exemplo, a Revista dos Tribunais. Uma dificuldade em relação à busca por bibliografia jurídica foi que as bibliotecas das faculdades de direito possuíam em seu acervo livros desatualizados, alguns que ainda tratavam da doutrina menorista, chegando a nomeação encontrada nos espaços ser "direito do menor". 
Diferentemente das bibliotecas dos cursos de educação, serviço social e psicologia, nos quais a criança e o adolescente já são foco de pesquisa há algum tempo, em que havia ampla bibliografia referente ao tema pesquisado Tal perspectiva é de extrema importância para um trabalho que tem como área de concentração os direitos humanos, pois rompe barreiras com relação aos outros saberes e enriquece a pesquisa numa perspectiva dialógica.

Assim, a bibliografia trabalhada procurou abranger não apenas a área propriamente jurídica, mas a educacional, sociológica e filosófica. Tal articulação interdisciplinar também se deu visto não ser fácil penetrar no âmbito dos meandros do direito (que tem muitas concepções, diversidades de ponto de vista - se aproximando muito mais de uma ciência social, do que de uma ciência aplicada) aos meandros da legislação e doutrina educacional.

A maior dificuldade encontrada foi com relação à pesquisa quantitativa, quando verificamos a escassez de decisões judiciais referentes ao tema da pesquisa, sendo encontradas decisões referentes à efetivação de outros direitos sociais que não o educacional, ou mesmo pertinentes à execução da MSE em um enfoque muito mais penalista do que constitucional educacional. Outra dificuldade, que levou uma perspectiva inicial de projeto ser deixada de lado ao longo da pesquisa, foi quanto à possibilidade de analise empírica, aplicação de questionários, ou mesmo realização de vivências nos estabelecimentos prisionais. Tal situação foi frustrada dada a dificuldade de realização de pesquisas no interior da Fundação CASA, as quais muitas vezes demoram mais de um ano para obter aprovação, podendo ser subitamente canceladas em razão de mudanças no governo.

Por fim, cumpre mencionar que apesar de vultuosa legislação referente ao direito à educação e ao fornecimento educacional, a presente pesquisa buscou se restringir às mais gerais e de maior incidência.

\section{Metodologia da Pesquisa}

O tema a ser discutido é complexo e amplo, envolvendo diversas áreas do conhecimento. Isto porque, tratar do direito fundamental à educação do adolescente em conflito com a lei - que se encontra em situação de privação de liberdade - acaba por envolver as áreas da educação e da sociologia, além de temas do direito, como criminologia e direito penal juvenil. 
Assim, a pesquisa terá natureza aplicada para atingir seu objetivo exploratório, que além de demonstrar familiaridade com o tema, buscará explicitá-lo a partir da pesquisa bibliográfica e documental somadas ao estudo de caso.

Para o desenvolvimento da pesquisa, o método científico a ser utilizado será o dialético, porque este, nas palavras de DEMO, "vê na história não somente o fluxo das coisas, mas igualmente a principal origem explicativa" ${ }^{, 20}$.

Tal método se justifica por considerar que nenhum fenômeno da natureza pode ser compreendido, quando encarado isoladamente, fora dos fenômenos que o circundam. Sendo o crime uma construção social, visto que nós (sociedade), dentro de um processo social de construção de valores mutáveis com o tempo, definimos o delito $^{21}$; e estando a concepção de infância e a doutrina em constante processo de mudança e avanço. A análise da educação de crianças e adolescentes em conflito com a lei deve ser compreendida e realizada considerando sua ligação indissolúvel com os fenômenos que a rodeiam.

No que toca às técnicas de investigação, utilizaremos a de investigação teórica, documental, bibliográfica e de estudo de caso.

BITTAR é claro ao afirmar que "a pesquisa não deve ficar confinada somente a se desenvolver a partir de uma técnica bibliográfica [...], nem sobre um modelo empírico-experimental" ${ }^{22}$ devendo se conjugar ou se adequar às técnicas de acordo com o campo de trabalho no qual se situa o tema a ser abordado.

Assim, utilizaremos as seguintes fontes de pesquisa: (i) legislação nacional e internacional, incluindo declarações, convenções e tratados internacionais, (ii) fontes bibliográficas diversas a respeito do tema; (iii) jurisprudência disponível no sítio eletrônico do Tribunal de Justiça do Estado de São Paulo (www.tjsp.gov.br); (iv) documentos públicos e dados disponíveis em sítios de órgãos oficiais como a Fundação CASA (www.casa.sp.gov.br), a Secretaria de Educação do Estado de São Paulo (www.educacao.sp.gov.br); Secretaria de Estado da Justiça e da Defesa da Cidadania do Estado de São Paulo (http://www.justica.sp.gov.br/novo_site/) o INEP (www.inep.gov.br), MEC (www.mec.gov.br), IBGE, (www.ibge.gov.br), e ONUBRASIL (www.onu-brasil.org.br).

\footnotetext{
${ }^{20}$ DEMO, Pedro, "Introdução à metodologia da ciência". 1987, p. 21. In. BITTAR, Eduardo Carlos Bianca. Metodologia da Pesquisa Jurídica. $9^{\mathbf{a}}$ edição. São Paulo: Saraiva, 2011.

${ }^{21}$ BARATTA, Alessandro. Criminologia crítica e crítica do direito penal. Rio de Janeiro: Revan, 2002.

22 BITTAR, Eduardo Carlos Bianca. Metodologia da Pesquisa Jurídica. $9^{a}$ edição. São Paulo: Saraiva, 2011. p. 201
} 


\section{I - O DIREITO FUNDAMENTAL À EDUCAÇÃO: DIREITO SOCIAL FUNDAMENTAL AO ESTADO DEMOCRÁTICO DE DIREITO}

1. O Estado Democrático de Direito e os Direitos Humanos; 2. O direito fundamental à educação; 3. Fontes do Direito Educacional; 4. Políticas públicas educacionais e jurisprudência

\section{O Estado Democrático de Direito e os Direitos Humanos}

\section{a. Conceitos e definições preliminares}

O Estado Brasileiro é um Estado Democrático de Direito, classificação esta que leva em conta a qualidade do poder exercido neste Estado, tendo na efetiva participação popular um dos seus princípios.

Previsto no artigo $1^{\circ}$ da Constituição da República Federativa do Brasil de 1988, o Estado encontra-se diretamente associado aos princípios legitimadores da Constituição Federal, quais sejam: a república e a democracia.

$$
\begin{aligned}
& \text { Art. } \mathbf{1}^{\mathbf{0}} \text { - A República Federativa do Brasil, formada pela união } \\
& \text { indissolúvel dos Estados e Municípios e do Distrito Federal, } \\
& \text { constitui-se em Estado Democrático de Direito e tem como } \\
& \text { fundamentos: } \\
& \text { I - a soberania; } \\
& \text { II - a cidadania; } \\
& \text { III - a dignidade da pessoa humana; } \\
& \text { IV - os valores sociais do trabalho e da livre iniciativa; } \\
& \text { V - o pluralismo político. }
\end{aligned}
$$

Parágrafo único - Todo o poder emana do povo, que o exerce por meio de representantes eleitos ou diretamente, nos termos desta Constituição.

Tais princípios designam "a supremacia do bem comum sobre os interesses individuais, o que implica moralidade e responsabilidade públicas, além da igualdade de todos e a valorização da dignidade humana" e "a supremacia da vontade popular" ${ }^{23}$, por isso a preservação dos direitos fundamentais. Outros princípios são derivados do

${ }^{23}$ RANIERI, Nina Beatriz Stocco. "O Estado Democrático de Direito e o Sentido da Exigência de Preparo da Pessoa para o Exercício da Cidadania, pela Via da Educação". Tese (Livre-Docência) Faculdade de Direito da Universidade de São Paulo. São Paulo, 2009, p. 246. 
binômio democracia e república, como a soberania popular (participação representativa e participação popular direta), a dignidade da pessoa humana, a cidadania e o pluralismo jurídico, princípios estes, relativos ao regime democrático e à vida política.

Vemos, assim, que o Estado Democrático de Direito é legitimado pela democracia, tendo seus objetivos, valores e princípios expressos constitucionalmente. $\mathrm{O}$ vocábulo democracia advém etimologicamente do grego dèmokratía, que significa o governo do povo, visto Demos $=$ povo e kratos $=$ força/poder, o que nos leva a concluir que a "democracia" somente ocorre no Estado no qual o povo detém o poder ${ }^{24}$, sendo exercida direta ou indiretamente, por meio de representantes eleitos, além de ser possível tanto em sistemas presidencialista, parlamentararista, republicano quanto monárquico.

Quando pensamos em democracia, logo nos vêm à mente a Grécia antiga e suas experiências democráticas em Atenas. Ocorre que o conceito grego de democracia apesar de guardar certa relação com o moderno, possui uma divergência fundamental no que diz respeito à noção de povo, isto porque a condição grega de cidadania possuía pressupostos que excluíam boa parte da população, como escravos, mulheres e estrangeiros, que politicamente marginalizada.

Segundo DALLARI, Aristóteles é taxativo ao afirmar que a cidade-modelo não deve jamais admitir um artesão a somar no número de seus cidadãos, já que "a virtude política, que é a sabedoria para mandar e obedecer, só pertence àqueles que não têm necessidade de trabalhar para viver, não sendo possível praticar-se a virtude quando se leva a vida de artesão ou mercenário". ${ }^{25}$ Vemos que a democracia grega era um reflexo dos valores presentes na cultura grega.

O primeiro Estado jurídico tem origem no pensamento de fins do século XVII e inícios do XVIII com as ideias iluministas (1650/1700)

, e nas ideias das revoluções Inglesa (1689), Americana (1776) e Francesa (1789), quando a crise do Ancien Régime trouxe novas ideias filosóficas e econômicas que defendiam a liberdade de pensamento e a igualdade dos homens perante as leis, além da democracia, do liberalismo econômico e da liberdade de culto e de pensamento.

A preferência pela democracia e a afirmação dos princípios democráticos se deu nos marcos do enfraquecimento do poder absolutista e do fortalecimento da

\footnotetext{
${ }^{24}$ SANTOS, Marcelo Fausto Figueiredo. Teoria Geral do Estado. $2^{\mathrm{a}}$ edição. São Paulo: Atlas, 2001. p. 81.

${ }^{25}$ DALLARI, Dalmo. Elementos de Teoria Geral do Estado. $23^{\mathrm{a}}$ edição. São Paulo: Saraiva, 2002. p. 146.
} 
burguesia, a qual, através da afirmação de direitos naturais da pessoa humana, buscou ascender politicamente. Para isso, apoiaram-se em grandes pensadores jusnaturalistas, como Locke e Rousseau.

John Locke pregava a limitação da autoridade real pela soberania do povo, sendo suas ideias de grande valia para aqueles que queriam se ver livres dos poderes da monarquia absolutista. Em sua obra $O$ segundo tratado sobre o governo ${ }^{26}$, que tem como base princípios liberais da doutrina contratualista, ele buscou universalizar suas teorias como a de distinção entre poder Legislativo e Executivo, bem como o direito de insurreição dos súditos, devendo sempre prevalecer a vontade soberana da comunidade nacional, única fonte do $\operatorname{poder}^{27}$.

Interessante notar que em seu pensamento, Locke utiliza conceitos caros à democracia moderna, como a liberdade, para validar a propriedade privada. Sendo a propriedade para ele, um direito natural que o Estado deve reconhecer e proteger, contraposição clara ao modelo feudal de propriedade. ${ }^{28}$.

Rousseau - outro pensador que influenciou a atual teoria de governo democrático -, por sua vez, chegou a manifestar seu descrédito pelos governos democráticos, dizendo que "se existisse um povo de deuses, ele se governaria democraticamente. Tão perfeito governo não convém entre homens". ${ }^{29}$ Mesmo assim, podemos ver em sua obra diversos princípios inerentes ao Estado Democrático; ele considerava, por exemplo, que todos deveriam estar em condições de igualdade para que a democracia pudesse se efetivar.

Para Rousseau a representatividade era uma ideia incoerente com o princípio da democracia, pois esta deveria ser exercida de maneira direta, pelo próprio povo, de modo que a participação popular e a cidadania dependem de modo direto da

\footnotetext{
${ }^{26}$ LOCKE, John. O segundo tratado sobre o governo. São Paulo: Ibrasa, 1963.

${ }^{27}$ MALUF, Sahid. Teoria Geral do Estado. $23^{\mathrm{a}}$ edição, revisada e atualizada. São Paulo: Saraiva, 1995. p. 121.

${ }^{28}$ Tanto que Peter Laslett é enfático ao afirmar que o autor introduz “(...) um motivo para a instauração da sociedade política que poucos consideraram no contexto das origens políticas, um motivo ao qual ninguém atribuiu muita importância. De forma abrupta, Locke insere na discussão o conceito de propriedade" (LASLETT, Peter. "A teoria social e política dos dois tratados sobre o governo". In: QUIRINO, Célia Galvão \& SOUZA, Maria Tereza Sadak R. de (Orgs.). O pensamento político clássico, cit. p. 214-5.) De igual opinião é Harold Laski para quem "Locke não teve dificuldade em considerar que o Estado era feito para proteger os interesses de um homem que, pelo seu próprio esforço, acumulou bens e propriedades",de modo que para ele, "se a propriedade é a consequência do trabalho, então ele tem, claramente, todo o direito à segurança, pois esta é a 'grande e principal finalidade' da união dos homens em comunidade” (LASKI, Harold J. O liberalismo europeu. São Paulo: Mestre Jou, 1973. p. 84).

${ }^{29}$ ROUSSEAU. Jean-Jacques, O Contrato Social, Livro III, Capítulos III e IV.
} 
forma como está constituído -o Estado. Devendo sua estrutura conter mecanismos que permitam a manifestação da vontade geral.

Como já dito anteriormente, foram três os grandes movimentos políticosociais que transpuseram do plano teórico para o prático os princípios condutores da democracia: a Revolução Inglesa (Revolução Gloriosa), a Revolução Americana e a Revolução Francesa. A primeira, fortemente influenciada por Locke ${ }^{30}$, consolidou, no limiar do século XVIII, sua estrutura monárquica, cuja tripartição do poder, sistema representativo, preemência da opinião nacional e intangibilidade dos direitos fundamentais do homem $^{31}$ teve no Bill of Rights (1689) sua expressão mais significativa.

Por sua vez, a Revolução Americana, sofrendo forte influência das ideias liberais irradiadas da metrópole inglesa, estabeleceu seus princípios liberais na Declaração de Independência Americana, datada de 4 de julho de 1776, cujo preâmbulo, demonstra o espírito que ensejou a elaboração do documento, verbis:

Cremos axiomáticas as seguintes verdades: que todos os homens foram criados iguais, que lhes conferiu o Criador certos direitos inalienáveis, entre os quais o de vida e de liberdade, e o de procurarem a própria felicidade, que, para assegurar esses direitos, se constituíram entre os homens governos cujos justos poderes emanam do consentimento dos governados; que sempre que qualquer forma de governo tenta destruir esses fins, assiste ao povo o direito de mudá-la ou aboli-la, instituindo um novo governo cujos princípios básicos e organizações de poderes obedeçam às normas que lhe parecerem mais próprias a promover a segurança e a felicidade gerais.

Por fim, o terceiro movimento, foi a Revolução Francesa; considerada um dos principais movimentos inspiradores da construção dos direitos fundamentais pelo conteúdo eminentemente universalista dos direitos esparsamente já consagrados na Declaração dos Direitos do Homem e do Cidadão, de 1789, a qual dispunha em seu artigo 16, que: "Toda sociedade que não assegura a garantia dos direitos nem a separação dos poderes não possui constituição”.

BONAVIDES nos mostra o quanto a Revolução Francesa tornou-se "gênero de importantíssimas renovações institucionais, na medida em que içou, a favor do

\footnotetext{
30 "Esta liberdade em relação ao poder absoluto e arbitrário é tão necessária à preservação do homem e a ela está tão intimamente conjugada, que não lhe é dado desfazer-se dela senão mediante o que lhe faz perder juntamente a preservação e a vida.” John Locke - Segundo tratado sobre o governo, 1690.

${ }^{31}$ MALUF, Sahid. Teoria Geral do Estado. $23^{a}$ edição, revisada e atualizada. São Paulo: Saraiva, 1995. p. 124.
} 
Homem, a tríade da liberdade, igualdade e fraternidade [...]", promulgando as "Constituições do chamado Estado Democrático"32. Cumpre complementar o tema com anotações acerca do tipo de Estado que se organizou para ser democrático, qual seja, o Estado Constitucional e todas as teorias que informam as Constituições em relação às suas formas de Estado e de governo. A importância da Constituição se faz por ser esta uma carta de intenções do poder, que irá fundamentar e guiar as ações do Estado.

Durante o "constitucionalismo antigo", a Constituição era a organização do exercício do poder político que não necessariamente coincidia com o conceito de norma jurídica. Ela não guardava um conteúdo do "dever ser" (que o Estado tem condições de impor e o dever de garantir), sendo simplesmente uma mera fotografia do poder (o retrato estático da forma como o Poder está estabelecido conforme o afirmado por Lassale $\left.^{33}\right)$.

A emergência do "constitucionalismo novo"34 - modelo que surgiu no século XX - trouxe transformações sensíveis ao direito constitucional e ao conceito de Estado, tais quais o reconhecimento da força normativa da Constituição, a expansão da jurisdição constitucional, e o desenvolvimento da dogmática da interpretação constitucional.

"Neoconstitucionalismo" é um termo obviamente empregado para distinguir esta doutrina daquela do final do século XVIII, para designar a superação, em certa medida, do positivismo e do jusnaturalismo. Embora ambas designem doutrinas que se voltam à limitação do poder estatal, enquanto a última diz como uma Constituição deve ser (cf. art. 16 da Declaração de 1789) o neoconstitucionalismo é, sobretudo, uma política constitucional (Pozzolo, 2006:78), a indicar não como o direito é, mas como deve ser. ${ }^{35}$

Assim, da norma jurídica que organiza, condiciona e legitima o exercício do poder político, adveio um novo modelo de Estado, nos chamados Estados Constitucionais, passando a considerá-lo não como um fim em si mesmo, mas como um instrumento de garantias de direitos, por exemplo, para assegurar uma sociedade igual.

\footnotetext{
${ }^{32}$ BONAVIDES, Paulo. Do Estado Liberal ao Estado Social. $9^{\text {a }}$ Ed. São Paulo: Malheiros Editores. 2009. p. 30 .

${ }^{33}$ LASSALE, Ferdinand. Que é uma Constituição? São Paulo: Edições e Publicações Brasil, 1933.

${ }^{34}$ BARROSO, Luís Roberto. "Neoconstitucionalismo e constitucionalização do direito: o triunfo tardio do direito constitucional no Brasil". Revista de direito constitucional e internacional, São Paulo, n. 58, p. 129/173, jan.-mar. 2007.

35 RANIERI, Nina Beatriz Stocco. "O Estado Democrático de Direito e o Sentido da Exigência de Preparo da Pessoa para o Exercício da Cidadania, pela Via da Educação”. Tese (Livre-Docência) Faculdade de Direito da Universidade de São Paulo. São Paulo, 2009, p. 118.
} 
Temos aqui a ideia de que todo o poder emana do povo, sendo a Constituição o instrumento que reconhece esta soberania.

Afigura-se-nos, assim, o Estado social do constitucionalismo democrático da segunda metade do século XX o mais adequado a concretizar a universalidade dos valores abstratos das Declarações de Direitos fundamentais. ${ }^{36}$

De igual posicionamento é corroborado por RANIERI ${ }^{37}$, que é clara ao afirmar o status de consagração constitucional dado aos direitos do homem, quando estes passaram a ser direitos constitucionais:

Além dos fundamentos da doutrina dos direitos humanos, o
constitucionalismo elaborado a partir do final do século XVIII
também favoreceu a utilização de mecanismos de distribuição e
descentralização de poderes dentro do Estado nacional por
intermédio das técnicas federalistas, das garantias de direitos e
do pluralismo partidário; numa etapa posterior, assegurou o
controle de constitucionalidade das leis.

Do ponto de vista das relações entre governantes e governados, instituiu uma configuração triangular entre os indivíduos, o Direito e o poder estatal, representada pelo parlamento, governo, povo, na qual os detentores do poder são reciprocamente responsáveis pelo seu controle, consoante a dinâmica do sistema constitucional que supõe a atribuição de poder do povo para o Parlamento e deste para o governo. Por conseguinte, além de ser um governo de leis, o constitucionalismo significou "responsabilidade governamental", considerando-se responsável o governo no qual o exercício do poder é reciprocamente dividido e mutuamente controlado.

O conceito contemporâneo de Constituição reconhece o povo como efetivo detentor do poder político, estabelece os procedimentos que legitimam o exercício deste poder pelos representantes (eleitos) dos seus efetivos titulares (o povo), condiciona o exercício do poder político à realização dos direitos fundamentais, e ainda garante a própria normatividade estabelecendo a separação dos poderes ${ }^{38}$, mecanismos de controle de constitucionalidade e procedimentos especiais para proceder a sua própria

\footnotetext{
${ }^{36}$ BONAVIDES, Paulo. Do Estado Liberal ao Estado Social. $9^{a}$ Ed. São Paulo: Malheiros Editores. 2009. p. 32 .

${ }^{37}$ RANIERI, Nina Beatriz Stocco. "O Estado Democrático de Direito e o Sentido da Exigência de Preparo da Pessoa para o Exercício da Cidadania, pela Via da Educação". Tese (Livre-Docência) Faculdade de Direito da Universidade de São Paulo. São Paulo, 2009, p. 94.

${ }^{38}$ Mecanismo de garantia da normatividade constitucional, já que um órgão do Estado garante o controle de outro órgão do Estado.
} 
reforma. $^{39}$ Nesse sentido, pode-se dizer que Constituição (em sua acepção contemporânea) é condição de Democracia, e só tem sentido de existir em Estados Democráticos.

Temos, assim, que Democracia são as condições que legitimam, procedimental e materialmente, o exercício do poder do povo, pelo povo e para o povo. Considerando "povo" como o conjunto mais amplo possível de pessoas relacionadas com Estado.

De tal modo, faz-se obsoleta a premissa de Aristóteles de que possa haver governos legítimos que não sejam democráticos. Tanto os procedimentos para a investidura dos governantes para o exercício do poder político quanto o propósito com o qual o poder político é exercido são condições da democracia. Ela é ao mesmo tempo, um procedimento e um valor material que só se garante por meio de uma Constituição específica.

Se tentarmos extrair um conceito material de Democracia, teremos uma síntese de liberdade e igualdade. Isto porque, o Estado democrático não é o que garante a liberdade absoluta, mas o que a assegura de forma igualitária para todo o seu povo, proporcionando, assim, igualdade de possibilidade para que todos participem, na mesma proporção, na formação e condução da própria ordem social (Estado/Direito).

Assim, em uma rápida síntese, destacamos que os princípios que passaram a nortear os Estados são: a supremacia da vontade popular, a preservação da liberdade e a igualdade de direitos. Cumpre, desse modo, transcrevermos o conceito de Democracia dado pela Organização dos Estado Americanos, nos artigos $1^{\circ}$ e $2^{\circ}$, da Carta Democrática Interamericana, aprovada em 11 de setembro de 2001:

\section{Artigo 1}

Os povos da América têm direito à democracia e seus governos têm a obrigação de promovê-la e defendê-la.

A democracia é essencial para o desenvolvimento social, político e econômico dos povos das Américas.

Artigo 2

O exercício efetivo da democracia representativa é a base do Estado de Direito e dos regimes constitucionais dos Estados membros da Organização dos Estados Americanos. A democracia representativa reforça-se e aprofunda-se com a participação permanente, ética e responsável dos cidadãos em

\footnotetext{
${ }^{39}$ Pois se eu posso alterar a norma que me condiciona, eu não estou sendo condicionado.
} 
um marco de legalidade, em conformidade com a respectiva ordem constitucional.

Concluímos que o conceito de Democracia é tão presente no Estado Contemporâneo, que até mesmo estados totalitários se definem como democráticos. Por esta razão, faz-se necessário o histórico e a conceituação do Estado Democrático de direito, porque na maioria das vezes tal conceito é utilizado de maneira equivocada, buscando fundamentar atitudes que não condizem com o real conceito de democracia, nem seus princípios informadores.

O Estado Democrático é aquele que garante a liberdade de forma igualitária e, com isso, a igualdade de possibilidade que todos participem na formação e condução da ordem social. Sendo o Estado concebido como sistema jurídico e político que visa a proteção de direitos fundamentais, a limitação do poder; e se constitui pelo conjunto de direitos ligados à ideia de dignidade da pessoa humana, faz-se necessário analisarmos seu conceito de direitos humanos vez que sua importância axiológica, acaba por fundamentar e legitimar todo o ordenamento jurídico.

\section{b. Os Direitos Humanos: Fundamentais e Sociais}

Os direitos fundamentais ${ }^{40}$ encontram proteção constitucional no disposto pelo artigo $5^{\circ}$ parágrafo $1^{\circ}$ da Constituição Federal de 1988, ao estabelecer que: "as normas definidoras dos direitos e garantias fundamentais tem aplicabilidade imediata". Tal entendimento tem por base a ideia contemporânea de direitos humanos, que os classifica como sendo universais, indivisíveis, interdependentes entre si, tendo como objetivo a garantia da dignidade humana.

SILVA destaca a dificuldade de se definir os direitos fundamentais do homem em um conceito sintético e preciso devido à sua ampliação e transformação na evolução histórico-social. Soma-se a isso, a extensa gama de definições e expressões utilizadas para designá-los, tais como direitos naturais, direitos humanos, direitos dos homens, direitos individuais, etc. Nesse sentido, ele conclui que a expressão "direitos fundamentais do homem é a mais adequada, pois

\footnotetext{
${ }^{40}$ A distinção entre os termos "humanos" e "fundamentais" foi superada pela visão de que ambos os termos tratam do mesmo instituto jurídico, recuperado por Ferreira Filho através da expressão "direitos humanos fundamentais". (RANIERI, Nina Beatriz Stocco. "O Estado Democrático de Direito e o Sentido da Exigência de Preparo da Pessoa para o Exercício da Cidadania, pela Via da Educação". Tese (LivreDocência) - Faculdade de Direito da Universidade de São Paulo. São Paulo, 2009, p. 274).
} 
além de referir-se a princípios que resumem a concepção do mundo e informam a ideologia política de cada ordenamento jurídico, é reservada para designar, no nível do direito positivo, aquelas prerrogativas e instituições que ele concretiza em garantias de uma convivência digna, livre e igual de todas as pessoas. $^{41}$

Temos, assim, que os direitos fundamentais são aqueles sem os quais a pessoa não vive e os demais direitos e garantias não se realizam. Eles se caracterizam pela sua historicidade, evoluem e se ampliam como o passar do tempo; inalienabilidade, já que são intransferíveis; imprescritibilidade, nunca deixando de ser exigíveis; e irrenunciabilidade, não se admitindo que deles se renunciem, mesmo que não exercidos.

A afirmação dos direitos fundamentais na Constituição reveste-se do que José Afonso da Silva chama de caráter de transcendental importância. Porém não basta serem previstos e reconhecidos, eles precisam ser garantidos e efetivados; tal qual BOBBIO desafia: "o problema real que temos de enfrentar, contudo, é o das medidas imaginadas e imagináveis para a efetiva proteção desses direitos"42.

$\mathrm{O}$ direito à educação é, dentre os direitos fundamentais, aquele que leva o individuo a desenvolver, com autonomia, as suas potencialidades como ser humano; e que no caso da criança e do adolescente em conflito com a lei, poderá, nas palavras de KONZEN "minimizar, para o destinatário, o grau de angústia e de sofrimento decorrente da perda ou da restrição da liberdade"43, além de auxiliá-lo no processo de resignificação.

$\mathrm{O}$ direito à educação também pode ser compreendido enquanto direito social, os quais podem ser classificados, segundo SILVA, da seguinte maneira:

Podemos dizer que os direitos sociais, como dimensão dos direitos fundamentais do homem, são prestações positivas proporcionadas pelo estado direta ou indiretamente, enunciadas em normas constitucionais, que possibilitam melhores condições de vida aos mais fracos, direitos que tendem a realizar a igualização de situações sociais desiguais. São, portanto, direitos que se ligam ao direito desigualdade ${ }^{44}$

Segundo BUCCI, "os direitos sociais representam uma mudança de paradigma no fenômeno do direito, a modificar uma postura abstencionista do Estado

\footnotetext{
${ }^{41}$ SILVA, José Afonso da. Curso de direito constitucional positivo. $30^{\mathrm{a}}$ edição, revista e atualizada. São Paulo: Malheiros, 2008. p. 178.

${ }^{42}$ BOBBIO, Norberto. A era dos direitos. 19a. Ed. Rio de Janeiro: Elsevier, 1992. p. 33.

43 KONZEN, Afonso Armando. Pertinência Socioeducativa. Reflexões sobre a natureza jurídica das medidas. Porto Alegre: Livraria do Advogado Ed., 2005. p. 92.

${ }^{44}$ SILVA, José Afonso da. Curso de direito constitucional positivo. $30^{a}$ edição, revista e atualizada. São Paulo: Malheiros, 2008. p. 268-269.
} 
para o enfoque prestacional, característico das obrigações de fazer que surgem com os direitos sociais" $" 45$; tais direitos aparecem nos textos normativos da Constituição Mexicana de 1917 e da Constituição de Weimar de 1934, podendo ser classificados como "direitos-meio" de fruição de direitos de primeira geração ${ }^{46}$ e demais direitos.

Tal relação entre igualdade e efetivação de direitos sociais é feita por diversos pensadores como o professor JAGUARIBE ${ }^{47}$ que tem na Democracia social uma organização cuja finalidade é o interesse público:

Democracia organizatória que configura a sociedade para os fins da coletividade: o Estado se torna fiscal da interdição de certas práticas que possam afetar o interesse público (medidas antitruste), e finalmente, ativo coordenador da economia (dirigismo) e preservador dos interesses da classe trabalhadora.

Temos, assim, que a garantia e efetivação dos direitos sociais, são condição necessárias ao conceito de Estado Democrático de Direito, sendo o direito fundamental à educação o mediador da atuação participativa e crítica do indivíduo, bem como o precursor dos demais direitos sociais.

Analisando o processo histórico de busca por direitos foi a Revolução Industrial que trouxe à luz diversas demandas trabalhistas, afinal, foi o momento no qual as massas operárias e o movimento sindical assumiram relevância $\operatorname{social}^{48} \mathrm{e}$ pautaram suas demandas por direitos. Esta, somada ao início da chamada $2^{\mathrm{a}}$ Era dos Direitos, Geração dos direitos econômico-sociais ${ }^{49}$, fizeram com que o Estado, agora chamado Estado Social de Direito, constituísse uma inovação no paradigma do Estado

\footnotetext{
${ }^{45}$ BUCCI, Maria Paula Dallari. "O conceito de política pública em direito". In Políticas Públicas: Reflexões sobre o conceito. p. 2-3.

46 "O professor Antonio Augusto Cançado Trindade entende, entretanto, que a classificação não tem nenhum fundamento jurídico, nem tão pouco fundamento na realidade, tratando-se de uma teoria fragmentária, incompatível com a complexidade do direito. Para este ilustre professor, a classificação toma os direitos humanos de maneira dividida, teoria inaceitável uma vez que, na sua concepção, os direitos são indivisíveis e interrelacionados. Uma interessante contribuição da crítica apresentada referese aos reflexos da classificação fragmentária sobre os direitos econômicos e sociais. Para os defensores da classificação em gerações, esses direitos são programáticos. Assim, enquanto as discriminações relativas a direitos individuais e políticos são absolutamente condenadas, as discriminações econômicas e sociais são toleradas, pois como entende a teoria fragmentária, são programáticos, portanto de realização progressiva. Ainda segundo o ilustre professor, em vez de ajudar a combater as discriminações econômicas e sociais, rejeitando-as, a teoria das gerações acaba por tolerá-las, convalidando as disparidades." ANGIEUSKI, Plínio Neves. Evolução dos Direitos Humanos: Crítica à Classificação em Gerações de Direitos. Boletim Jurídico. Edição no 138. Código da publicação: 745.

${ }^{47}$ JAGUARIBE, H. Brasil, sociedade democrática. Rio de Janeiro. José Olímpio, 1985.

${ }^{48}$ GRINOVER, Ada Pellegrini. "O controle de políticas públicas pelo Poder Judiciário". In O processo: estudos e pareceres. $2^{\mathrm{a}}$ edição revisada e ampliada. São Paulo: DPJ Editora, 2009. p. 36.

${ }^{49}$ Cumpre mencionais que a expressão "geração de direitos" sofre críticas da doutrina, visto o uso do termo "geração" nos dar falsa ideia de substituição de uma geração por outra, o que não ocorre, havendo assim um processo de acumulação de direitos.
} 
Liberal, transformando sua postura negativa (de abstenção) em uma postura positiva (de prestação). Tal mudança alterou a concepção de Estado e suas finalidades, tanto que diversas Constituições passaram a dispor sobre as garantias e proteções dos direitos sociais como um todo, garantindo com isso que tais direitos, por figurarem na Carta Maior, na carta de propostas de um país, não deixassem de ser previstos.

Seguindo a corrente, o Brasil também incorporou ao longo dos anos diversos direitos sociais a sua Carta Magna, dando maior ou menor importância a estes direitos conforme a conjuntura à época de cada modificação constituinte. $\mathrm{Na}$ atual constituição Federal, datada de 1988, o Estado Brasileiro tem dentre os objetivos fundamentais, constantes em seu artigo $3^{\circ}$ : "I - construir uma sociedade livre, justa e solidária; II - garantir o desenvolvimento nacional; III - erradicar a pobreza e a marginalização e reduzir as desigualdades sociais e regionais; e IV - promover o bem de todos, sem preconceitos de origem, raça, sexo, cor, idade e quaisquer outras formas de discriminação.", objetivos juridicamente vinculantes para todos os órgãos estatais, levando-nos a concluir que o nosso Estado Democrático Social de Direito destina-se a assegurar o exercício de direitos sociais e individuais, direitos estes fundamentais.

Temos um Estado que deve intervir sobre a realidade social para modificála; que se propõe transformador, não apenas mantenedor. Conforme já mencionado, o Estado Moderno, cujas bases foram concebidas no fim do século XVII e ao longo do século XVIII, é tido como “organização necessariamente rígida e estática, porque o desafio político da época consistia em abolir o absolutismo monárquico, pela despersonalização do poder" ${ }^{\text {"50 }}$. Sendo necessária a norma geral e abstrata para substituir a vontade individual do governo absolutista.

Este Estado Moderno buscava a segurança individual, valor, nas palavras de COMPARATO, essencialmente estático e conservador; buscava a preservação da vida, da liberdade e da propriedade. A lei aparece para Locke e Montesquieu como regra geral e suprema de conduta, não sujeita a adaptações ou alterações (imutável), tal qual a norma Constitucional. Tal concepção restritiva vinha por limitar o poder estatal; limitação que Montesquieu buscou através do mecanismo da separação dos poderes, condicionando a liberdade dos cidadãos à divisão das funções do Estado.

DALLARI observa que a "teoria foi consagrada em momento histórico no qual se pretendia o enfraquecimento do Estado e a sua restrição na esfera de liberdade

\footnotetext{
${ }^{50}$ COMPARATO, Fábio Konder. Ensaio sobre o juízo de constitucionalidade de políticas públicas, in Revista dos Tribunais, Ano 86, V. 35, 1997, p. 12.
} 
individual". ${ }^{51}$ Assim, a separação dos poderes serviu para refrear a interferência da realeza nas decisões dos juízes ${ }^{52,53}$.

A transição entre o Estado Liberal e o Estado Social promove alteração substancial quanto à concepção de Estado e sua finalidade ${ }^{54}$. A teoria de Separação dos Poderes não pode ser um fim em si mesma devendo estar estreitamente ligada às finalidades do Estado, de modo que com a alteração destas, a concepção da teoria também se altera:

No Estado liberal, o objetivo da teoria da separação dos poderes, consoante já assentado era o de evitar a concentração do poder estatal, a fim de que os direitos fundamentais de primeira geração fossem assegurados. O Estado, na premissa liberal, é um elemento catalisador do poder, instrumento para a sua contenção, em estrito respeito à liberdade individual.

No Estado social, este objetivo permanece, mas se lhe é acrescentado o desiderato de realização dos direitos fundamentais de segunda e outras gerações; com o propósito de se assegurar a igualdade substancial entre os cidadãos. De uma conduta meramente negativa, o Estado assume, também, uma conduta pró-ativa. ${ }^{55}$.

Apesar das constituições liberais procurarem a "inação" estatal, a Revolução Industrial e o "movimento das coisas" necessário um planejamento estratégico, escolhendo-se fins e objetivos comuns bem

\footnotetext{
${ }^{51}$ DALLARI, Dalmo de Abreu. Elementos de teoria geral do Estado, 26 ed., São Paulo: Saraiva, 2007. p. 216.

52 "Os reis ingleses, por sua influência direta na composição e na atuação dos órgãos jurisdicionais, não raras vezes tentavam intervir nas decisões exaradas nos casos concretos de maior relevância". CANELA. Oswaldo Jr.

${ }^{53}$ Ele também nos lembra que Montesquieu "exerceu a magistratura. Entretanto, o seu acesso às funções judicantes operou-se hereditariamente. Assim é que Montesquieu herdou de um tio, no ano de 1716, o cargo de membro do Parlement de Bordeaux, órgão judiciário coletivo, cargo que acabou vendendo por necessidade financeira e porque não nutria qualquer interesse pela atividade." DALLARI, Dalmo de Abreu. O poder dos juízes. São Paulo: Saraiva, 1996, p.15. apud CANELA. Oswaldo Jr. O controle Judicial de Políticas Públicas. $1^{\text {a }}$. Edição. São Paulo: Saraiva, 2011. p.69.

${ }^{54}$ Concepção esta que segundo Oswaldo Canela Junior mudou de aspecto: "e assim a teoria da separação dos poderes (art. $2^{\circ}$ da CF brasileira) muda de feição, passando a ser interpretada da seguinte maneira: o estado é uno e uno é seu poder. Exerce ele seu poder por meio de formas de expressão (ou Poderes). Para racionalização da atividade estatal, cada forma de expressão do poder estatal exerce atividade específica, destacada pela Constituição. No exercício de tais funções é vedado às formas de expressão do poder estatal interferências recíprocas: é este o sentido da independência dos poderes." CANELA, Oswaldo. Jr. A efetivação dos direitos fundamentais através do processo coletivo: um novo modelo de jurisdição (tese de doutorado apresentada na USP sob orientação de Kazuo Watanabe). apud GRINOVER, Ada Pellegrini. O controle de políticas públicas pelo Poder Judiciário. O processo: estudos e pareceres. $2^{\mathrm{a}}$ edição revisada e ampliada. São Paulo: DPJ Editora, 2009. p. 39.

${ }^{55}$ CANELA, Oswaldo. Jr. O controle Judicial de Políticas Públicas. 1ª Edição. São Paulo: Saraiva, 2011. p.72.

${ }^{56}$ COMPARATO, Fábio Konder. "Ensaio sobre o juízo de constitucionalidade de políticas públicas”, In Revista dos Tribunais, Ano 86, V. 35, 1997, p. 16.
} 
como os instrumentos e meios para alcançá-los. Isto porque no séc. XIX as transformações sociais decorrentes da Revolução Industrial, a expansão em massa da população, somadas à concentração de riqueza acabaram gerando gigantescos bolsões de misérias nas classes inferiores.

O Estado Contemporâneo, assim, passou a ter legitimidade e capacidade para realizar objetivos predeterminados, e a reorganização da atividade estatal em função de finalidades coletivas tornou-se indispensável, passando a ser atribuição dos Poderes Públicos propiciar condições básicas ao alcance da igualdade social.

Tal mudança de modelo estatal de modelos estatais torna necessário um reexame da tradicional classificação dos Poderes de estado, pois diferentemente do modelo constitucional clássico, no qual o Legislativo é tido como um Poder Supremo, a legitimidade estatal passa a fundar-se na realização de finalidades coletivas (a serem concretizadas programadamente através de políticas públicas ou de programas de ação governamental), dando ao Poder Executivo um papel hegemônico. Realidade verificada no fornecimento de direitos sociais, como o direito à saúde e o direito à educação, que por serem direitos prestacionais, necessitam ser organizados dentro da divisão de competências do pacto federativo, e da atuação harmônica dos Poderes.

\section{O direito fundamental à educação}

O direito à educação, direito público subjetivo, é considerado para a maior parte da doutrina e da jurisprudência como sendo direito de eficácia plena e de aplicação imediata. Tanto que nos julgados do STF percebemos a inexistência de limites (tão invocados para a aplicação de direitos sociais) quando tratamos da saúde e da educação.

\section{a. Definição e fundamento}

A educação é um direito humano fundamental que deve ser garantido pelo Estado; por meio dela, nos desenvolvemos enquanto seres humanos e contribuímos para o desenvolvimento da sociedade como um todo.

Fernando Savater destaca que

[...] o ser humano é um ser inconcluso que necessita permanentemente da educação para desenvolver-se em sua plenitude, motivo por que a finalidade da educação é cultivar a 
humanidade. Esse caráter humanizador ${ }^{57}$ implica que a educação tem um valor em si mesma e que não é unicamente uma ferramenta para o crescimento econômico ou social, ainda que também o seja, como costumava perceber-se a partir de visões mais utilitaristas. ${ }^{58}$

A educação - que ocorre ao longo da vida do ser humano -, assim, é um

processo,

em que a criança ou o adulto convive com o outro e, ao conviver com o outro, se transforma espontaneamente, de maneira que seu modo de viver se faz progressivamente mais congruente com o do outro no espaço de convivência. O educar ocorre, portanto, todo o tempo estrutural contingente com uma história no conviver, e o resultado disso é que as pessoas aprendem a viver de uma maneira que se configura de acordo com o conviver da comunidade em que vivem ${ }^{59}$.

Conforme já mencionado anteriormente, a democracia pressupõe igualdade de oportunidades e participação social, efetivados por meio da educação. Isto porque a Democracia não pode prescindir de cidadãos preparados para exercê-la. MONTESQUIEU ressalta a necessidade de o povo, de participação imprescindível à democracia, ter acesso às informações que lhes subsidiem no sufrágio:

O povo, na democracia, é sob certos aspectos, o monarca; sob outros, é o súdito. Não pode ser monarca senão por meio de seus sufrágios que constituem suas vontades. A vontade do soberano é o próprio soberano. [...] O povo é admirável para escolher aqueles a quem deve confiar parte de sua autoridade. Para deliberar, não dispõe senão de coisas que não pode ignorar e de fatos que são palpáveis. ${ }^{60}$

Vemos, assim, a relação direta entre a educação e o exercício democrático, que se consubstancia não só no voto, mas na vivência cidadã ativa, participativa, na capacidade de julgar e escolher.

\footnotetext{
${ }^{57}$ Paulo Freire reconhece o homem enquanto ser histórico e por este motivo, ser que "está sendo", ser inacabado, inconcluso, "em e com uma realidade, que sendo histórica também, é igualmente inacabada", e o mais importante, ser que se sabe inacabado, consciência na qual se encontram as raízes da educação como manifestação exclusivamente humana; educação que Paulo Freire define como um "que-fazer permanente" devido à inconclusão humana e à realidade sempre em mutação, maneira pela qual a educação se refaz constantemente na práxis, afinal, "para ser tem que estar sendo".

${ }^{58}$ SAVATER, Fernando (2006), "Educação de qualidade para todos: um assunto de direitos humanos". Brasília: UNESCO, OREALC, 2007. Documento de discussão sobre políticas educativas no marco da II Reunião Intergovernamental do Projeto Regional de Educação para a América Latina e o Caribe (EPT/PRE), 29 e 30 de março de 2007, Buenos Aires, Argentina, 2007. p. 138.

${ }^{59}$ MATURAMA, Humberto. Emoções e Linguagem na Educação e na Política. Belo Horizonte: Editora UFMG, 2002, p. 29. apud KONZEN, Afonso Armando. Pertinência Socioeducativa. Reflexões sobre a natureza jurídica das medidas. Porto Alegre: Livraria do Advogado Ed., 2005. p. 80.

${ }^{60}$ MONTESQUIEU. Sociedade e Poder. In. WEFFORT, Francisco C. Os Clássicos da Política. 14 ${ }^{\mathrm{a}} \mathrm{ed}$. São Paulo: Ática, 2006. p. 127-128.
} 


\section{b. Educação e Ensino}

Primeiramente, faz-se necessário diferenciar os vocábulos educação e ensino, uma vez que apesar serem utilizados como equivalentes, possuem significados distintos; educação tem significado mais amplo que ensino. BITTAR ${ }^{61}$ diferencia os vocábulos, argumentando que:

[...] a educação envolve todos os processos culturais, sociais, éticos, familiares, religiosos, ideológicos, políticos que se somam para a formação do indivíduo. Trata-se de vislumbrar na educação, nesse sentido, a formação e o desenvolvimento das faculdades e potencialidades humanas, sejam físicas, sejam morais, sejam intelectuais por quaisquer meios possíveis e disponíveis, extraídos ou não do convívio social.

Por sua vez, ensino representa uma relação mais pontual, que se destaca de um processo de aprendizado, direcionado e direto, em que se podem detectar dois polos relacionais, a saber, o educador e o educando. $\mathrm{O}$ ensino tem mais a ver com o engajamento da atividade educacional em relações privadas ou públicas de prestação de serviços educacionais, tenentes à formação elementar do indivíduo nas ciências, nas práticas e nos saberes constituídos pelos progressos da humanidade. Quando se menciona a palavra ensino, está-se a vislumbrar uma atividade de transmissão de conhecimento dentro de parâmetros predefinidos, formais, portanto, por meio dos quais se transporta a experiência de um para outro ser.

RANIERI nos chama atenção para o imenso número de palavras que deriva de ambos os vocábulos, mostrando-nos que estes são empregados pela Constituição Federal de 1988, pela LDB (Lei 9.394, de 20 de dezembro de 1996) ou mesmo pelo ECA (Lei n 8.069, de 13 de julho de 1990), muitas vezes como sinônimos ${ }^{62}$.

Das palavras educação e ensino derivam - ou a elas se associam, direta ou indiretamente - os termos "educador", "educando", "professor", "magistério", "aluno", "creche”, "préescola", "universidade", "pedagogia", "frequência escolar", "dias letivos", "critérios avaliativos" etc. Nesse conjunto, podemos ainda distinguir, em outro estágio interpretativo, entre o direito à educação e os direitos na educação, que nos remetem

\footnotetext{
${ }^{61}$ BITTAR, Eduardo G. B. Direito e Ensino Jurídico: Legislação Educacional. São Paulo: Editora Atlas S.A., 2001.p. 15-16.

62 RANIERI, Nina Beatriz Stocco. "O Estado Democrático de Direito e o Sentido da Exigência de Preparo da Pessoa para o Exercício da Cidadania, pela Via da Educação”. Tese (Livre-Docência) Faculdade de Direito da Universidade de São Paulo. São Paulo, 2009, p. 277.
} 
a "qualidade", "acesso à escola pública e gratuita próxima da residência", "participação em entidades estudantis" etc.

Concluímos, assim, que o ensino é apenas "um capítulo da educação de uma pessoa", enquanto que esta envolve diferentes processos socioculturais que formam o indivíduo. Vale ressaltar que ambos (educação e ensino) são positivados e garantidos pelo Estado. (CF, arts. 205 e 206.). Igual definição encontramos na Convenção contra a Discriminação na Escola de 1960, art. 1º no 2 (no Brasil, Decreto no 63.223, de 6 de setembro de 1968), que define o ensino como a educação que se dá no ambiente escolar.

Assim, todos devem ter o direito de acesso ao ensino, que é o "meio pelo qual a pessoa adquire conhecimentos formais para seu engajamento social". Neste sentindo, ele qualifica o indivíduo desenvolvendo suas habilidades e integrando-o socialmente $^{63}$, constituindo-se no que BITTAR define como o meio para a realização de parte do processo educacional e instrumento de grande importância para a realização de justiça social. O acesso ao ensino acaba, assim, desenvolvendo potencialidades humanas (puramente técnicas, ou puramente intelectuais ou aplicativas ${ }^{64}$ ).

Por sua vez, a educação, sendo mais, ampla, fortalece os liames éticos, dignifica o cidadão, ampliando seus horizontes e suas opções intelectuais, morais, sociais, cívicas e laborais. É a educação que alavanca o cidadão para o desenvolvimento ${ }^{65}$; assim, cabe a ela a formação da consciência cívica, base do progresso social, constituindo-se em um meio de fortalecimento dos elos racionais e culturais, um "ingrediente capaz de reduzir as desigualdades, de favorecer a distribuição de riquezas, de modo que, em suas múltiplas funções, a educação é sempre indicada como um bom remédio social" ${ }^{\prime 66}$.

Ao longo da Constituição Federal, a educação aparece sob diferentes formas e termos, sendo importante observarmos os significados e conceitos que cada um deles leva. A principal diferenciação entre os termos educação e ensino é que enquanto a primeira visa sentimentos como pertencimento, reconhecimento, amor e os põe sob o controle da vontade, o ensino é instrução e se dirige ao intelecto. Tal diferença fica

\footnotetext{
${ }^{63}$ A escola é depois da família o primeiro espaço de troca e interação social do indivíduo, sendo o seu primeiro contato com o outro.

${ }_{64}^{64}$ BITTAR, Eduardo G. B. Direito e Ensino Jurídico: Legislação Educacional. São Paulo: Editora Atlas S.A., 2001.p. 15-16.

${ }^{65}$ MONTORO, André Franco Jr. Estudos de filosofia do direito. 3. ${ }^{\text {a }}$ ed., São Paulo: Saraiva, 1999. p. 171-173.

${ }^{66}$ BITTAR, Eduardo G. B. Direito e Ensino Jurídico: Legislação Educacional. São Paulo: Editora Atlas S.A., 2001.p. 20-21.
} 
evidente quando pensamos na educação como um todo, que não se limita ao espaço escolar, enquanto o ensino, mais restrito, é aplicado neste.

Tais motivos por si só já seriam suficientes para a criação de medidas efetivas que permitam a todos não só o acesso à educação, mas também sua manutenção. Isto porque ele acaba por tornar-se o acesso aos demais direitos, à participação efetiva do indivíduo na sociedade. No mesmo sentido, para BITTAR:

Sabendo-se que não se pode pensar em construir um Estado Democrático de Direito mantendo a maior parte dos cidadãos excluídos ou alijados do processo educacional é que foi ampliada a disciplina normativa da questão da educação, no contexto da construção da Constituição Cidadã. Por isso, a $\mathrm{CF} / 88$ dedica um capítulo inteiro à questão da educação, após colocar em patamar todo especial, entre as garantias fundamentais do art. $5^{\circ}$, os direitos intelectuais e a liberdade de expressão, que são a condição para que o ensino livre exista e se desenvolva. ${ }^{67}$

Assim, no que tange ao ensino público, este deve ser acessível a todos, de qualidade, devendo haver forte investimento nos professores, em programas suplementares - como a oferta de alimentação, material escolar e transporte -, no policiamento, entre outros. Também são condições de realização do ensino público no Brasil a igualdade de oportunidades e a garantia de vagas para todos.

$\mathrm{Na}$ presente pesquisa, adotaremos o termo escolarização para tratar desta educação formalizada pelo equipamento estatal e controlada não apenas de forma instrumental, mas também ideologicamente.

\section{c. Acesso à educação}

O acesso à educação pode ser considerado um dos mais eficazes meios para alcançar este direito tão primordial que é a dignidade da pessoa humana. A dignidade diz com a condição humana do ser humano, guardando íntima relação com as complexas manifestações da personalidade humana ${ }^{68}$. SARLAT ao tratar das dimensões da dignidade salienta como esta é vista enquanto constituinte do valor próprio que

\footnotetext{
${ }^{67}$ BITTAR, Eduardo G. B. Direito e Ensino Jurídico: Legislação Educacional. São Paulo: Editora Atlas S.A., 2001.p. 20-21.

68 SARLET, Ingo Wolfgang (org.). As dimensões da dignidade da pessoa humana: construindo uma compreensão jurídico-constitucional necessária e possível. $2^{a}$. ed. e ver. e ampl. Porto Alegre: Livraria do Advogado Editora, 2009. p. 15.
} 
identifica o homem, sendo algo real, irrenunciável e inalienável. Significa que a dignidade deve ser não apenas reconhecida e respeitada, mas protegida e promovida.

O presente trabalho se propõe a tratar do direito à educação nas situações de privação de liberdade, situações nas quais muitas vezes encontramos indivíduos que foram privados desta dignidade social, deste reconhecimento simbólico tão necessário ao ser humano, acabando a buscar outras formas de reconhecimento e de afirmação enquanto ser humano, realizando o que OLIVEIRA chama de descolamento:

Diante da recusa do reconhecimento simbólico destes jovens, ante o desprezo e indiferença a que são submetidos eles buscam inventar outro espaço, um deslocamento de lugar, o que o permite definir o delinquente juvenil como "um adolescente desalojado que busca de forma exacerbada um atalho de reconhecimento, ${ }^{, 69}$

Como resignificar esses jovens socialmente excluídos, senão através da educação em seu sentido mais amplo, capaz de dentro da reclusão resignificar a vida intra e extramuros dos jovens, conferindo-lhe um sentido.

Com relação ao conceito de educação, PAULA afirma que

juridicamente podemos conceber a educação como um direito público subjetivo. Deve ser materializado através de política social básica, porquanto indiscutível relacionado à cidadania e à dignidade humana, dois fundamentos constitucionais da República Federativa do Brasil ( $\mathrm{CF}$, art. $\left.1^{\circ}\right)$, bem como é pertinente aos objetivos primordiais e permanentes do Estado brasileiro $\left(\mathrm{CF}\right.$, art. $\left.3^{\circ}\right)$, notadamente o referente à erradicação da marginalidade. $^{70}$

A educação abrange, assim, tanto o atendimento a crianças em idade escolar (2-18 anos) em creches, pré-escolas e ensino fundamental, quanto àqueles que não tiveram acesso à educação na idade própria, como é o caso da grande maioria dos encarcerados no Brasil. Implicando ao Estado o dever de proporcionar a efetivação desse direito.

Cumpre mencionar que este dever é do Estado como um todo, isto é, das ações conjuntas de seus órgãos e Poderes. Neste sentido, SARI afirma a necessidade de

\footnotetext{
69 Oliveira, Carmen Silveira de. Sobrevivendo no inferno. A violência juvenil contemporânea. Porto Alegre: Sulina, 2001, p. 99. apud VICENTIN, Maria Cristina Gonçalves. A vida em Rebelião. Jovens em conflito com a Lei. São Paulo: Hucitec: Fapesp, 2005. p. 210)

70 PAULA, Paulo Afonso Garrido de. "Educação, Direito e cidadania", Revista Igualdade. Livro 0. Curitiba, s/Ed., outubro-dezembro/1995. p. 13.
} 
um novo entendimento sobre gestão pública que vise impulsionar mudanças na área educacional:

Trata-se de incluir e valorizar novos agentes sociais capazes de provocar avanços e de conferir mais eficácia às ações decorrentes das políticas públicas. Por isso, entende-se que, além das responsabilidades confiadas ao Poder Público, também são atribuídos deveres à sociedade, aos cidadãos e às suas entidades representativas. No Poder público não basta a atuação do Executivo para garantir o já instituído; é indispensável a vigilância do Poder Legislativo e também do Poder Judiciário, bem como do Ministério Público, sobre as realizações em curso e sobre as novas demandas sociais ${ }^{71}$

Assim, o acesso à educação, mais do que um direito fundamental, é uma obrigação estatal e questão de política pública; ao tratarmos do direito fundamental à educação, não podemos nos esquecer que ele não deve ser apenas protegido, mas deve ser garantido e implementado.

\section{Fontes Nacionais do Direito Educacional}

\section{a. Constituição da República Federativa do Brasil}

O direito à educação (social e individual) no Estado Brasileiro é previsto nos artigos $6^{\circ}$ e 205 da Constituição Federal. A primeira Constituição brasileira a tratar do direito à educação foi a Constituição Política do Império do Brasil, de 1824, que consagrou em um dos incisos do art. 75, o direito "à gratuidade do ensino primário". Por sua vez, a Constituição Republicana de 1891 tratou da "gratuidade do ensino leigo" em seu art. 72. A Constituição de 1934 ampliou a normatização referente ao direito à educação, quando em seu artigo 149, dispôs que:

Art. 149. A educação é direito de todos e deve ser ministrada, pela família e pelos Poderes Públicos, cumprindo a estes proporcioná-la a brasileiros e a estrangeiros domiciliados no país, de modo que possibilite eficientes fatores da vida moral e econômica da Nação, e desenvolva num espírito brasileiro a consciência da solidariedade humana.

A posterior Constituição de 1937 estabeleceu em seu art. 130, que:

Art. 130. O ensino primário é obrigatório e gratuito. A gratuidade, porém, não exclui o dever de solidariedade dos

\footnotetext{
71 SARI, Marisa Timm. “A organização da Educação Nacional. (67-120)”. In. LIBERATI, Wilson Donizeti (org.). Direito à educação: Uma questão de justiça. São Paulo: Malheiros, 2004. p. 69.
} 
menos para com os mais necessitados; assim, por ocasião da matrícula, será exigida aos que não alegarem, ou notoriamente não puderem alegar escassez de recursos, uma contribuição módica e mensal para a caixa escolar.

A Constituição de 1946 fez voltar o preceito de que educação é direito de todos, afirmando em seu art. 166 que:

Art. 166. A educação é direito de todos e será dada no lar e na escola. Deve inspirar-se nos princípios de liberdade e nos ideais de solidariedade humana.

Seus artigos seguintes tratam dos princípios de gratuidade e obrigatoriedade do ensino, de modo que a Constituição de 1946 é tida como bastante avançada para a época, progredindo na consolidação da democracia e das liberdades individuais. Posteriormente, já sob a ditadura civil-militar instituída após o golpe de Estado de 1964, a Emenda Constitucional 1/1969, promulgada pela Junta Militar acrescentou ao dispositivo forte ideologia nacionalista, um retrocesso nos direitos civis e políticos. Interessante observar a relação de tal ideologia com a educação, disposta em seu art. 176:

A educação, inspirada no princípio da unidade nacional e nos ideais de liberdade e solidariedade humana, é direito de todos e dever do estado, e será dada no lar e na escola.

Por fim, a Constituição de 1988, coloca a educação no patamar de direito social, dispondo, em seu artigo $6^{\circ}$, que o direito à educação é fundamental e social. Assim, ex vi, do artigo 6 da CF de 1988: "São direitos sociais a educação, a saúde, o trabalho, o lazer, a segurança, a previdência social, a proteção à maternidade e à infância, a assistência aos desamparados, na forma desta Constituição”. Nos dizeres de MORAIS:

[...] A definição dos direitos sociais no título constitucional destinado aos direitos e garantias fundamentais acarreta duas consequências imediatas: subordinação à regra da autoaplicabilidade prevista no parágrafo $1^{\circ}$, do art. $5^{\circ} \mathrm{e}$ suscetibilidade do ajuizamento do mandado de injunção, sempre que houver a omissão do poder público na regulamentação de alguma norma que preveja um direito social, e consequentemente inviabilize seu exercício. ${ }^{72}$

\footnotetext{
${ }^{72}$ MORAES, Alexandre de. Curso de direito constitucional. 23ª ed. São Paulo: Atlas, 2008. p. 194.
} 
Como adverte BOAVENTURA ${ }^{73}$ : "Ao lado do direito à educação deve estar a obrigação de educar". Obrigação tão cara ao Estado Brasileiro que a Constituição de 1988 determina ser a educação um direito fundamental, ou seja, um direito público subjetivo, nos termos dos artigos 205 e $208, \S 1^{\circ}$ e reforça essa obrigação estatal ao definir a educação como: (I) direito de todos; (II) dever do Estado e da família, devendo ser promovida e incentivada com a colaboração da sociedade; (III) visando ao pleno desenvolvimento da pessoa; (IV) seu preparo para o exercício da cidadania; e sua (V) qualificação para o trabalho, na conformidade com as disposições dos artigos 205 e $208^{74}$

A Constituição estabelece em seu artigo 205 que o direito à educação é "direito de todos e dever do Estado e da família", devendo esta ser "promovida e incentivada com a colaboração da sociedade, visando ao pleno desenvolvimento da pessoa, seu preparo para o exercício da cidadania e sua qualificação para o trabalho."

LIBERATI é claro ao definir os objetivos constitucionais da educação como: “a) pleno desenvolvimento da pessoa; b) preparo da pessoa para o exercício da cidadania; c) qualificação da pessoa para o trabalho"75. Objetivos interligados aos demais princípios constitucionais, de modo que ao afirmar os norteadores do ensino, o constituinte nada mais fez do que esmiuçar princípios de direitos e garantias já dispostos na Constituição.

Art. 206 - O ensino será ministrado com base nos seguintes princípios:

I - igualdade de condições para o acesso e permanência na escola;

II - liberdade de aprender, ensinar, pesquisar e divulgar o pensamento, a arte e o saber;

III - pluralismo de ideias e de concepções pedagógicas, e coexistência de instituições públicas e privadas de ensino;

IV - gratuidade do ensino público em estabelecimentos oficiais;

V - valorização dos profissionais da educação escolar, garantidos, na forma da lei, planos de carreira, com ingresso

${ }^{73}$ BOAVENTURA, M. Edivaldo. "Um ensaio de sistematização do direito educacional". Revista de Informação Legislativa. Brasília. Ano. 33, N. 131. Julho a setembro de 1996, p. 32

${ }^{74}$ LINHARES, Mônica Tereza Mansur, "O Direito à Educação como Direito Humano Fundamental". In: Revista Jurídica da Universidade de Franca. Publicação do Curso de Direito da Universidade de Franca. Franca. Ano 7, n. 13. $2^{\circ}$ semestre. Franca, 2004. p. 159.

${ }^{75}$ LIBERATI, Wilson Donizeti. "Conteúdo material do direito à educação (208-260)". In. LIBERATI, Wilson Donizeti (org.). Direito à educação: Uma questão de justiça. São Paulo: Malheiros, 2004. p. 209. 
exclusivamente por concurso público de provas e títulos, aos das redes públicas;

VI - gestão democrática do ensino público, na forma da lei;

VII - garantia de padrão de qualidade.

VIII - piso salarial profissional nacional para os profissionais da educação escolar pública, nos termos de lei federal.

Temos que a educação é a chave para estabelecer e reforçar a Democracia. Assim, a Constituição Federal é categórica ao definir em seu art. 208 o acesso ao ensino obrigatório e gratuito como direito público subjetivo:

Art. 208 - O dever do Estado com a educação será efetivado mediante garantia de: [...]

Parágrafo. $1^{\circ} \mathrm{O}$ acesso ao ensino obrigatório e gratuito é direito público subjetivo.

Parágrafo. $2^{\circ} \mathrm{O}$ não oferecimento do ensino obrigatório pelo poder público, ou sua oferta irregular, importa responsabilidade da autoridade competente.

No que tange ao direito público subjetivo, prende-se a uma "[...] teoria fundamental, porquanto implica a afirmação de que o indivíduo possui uma esfera inviolável, em cujo âmbito o poder público não pode penetrar". ${ }^{76}$ LIBERATI afirma que “O status de direito público subjetivo exigível do Estado não deveria circunscrever-se somente ao acesso ao ensino obrigatório e gratuito, mas a todo o sistema educacional" ${ }^{77}$ Isto porque segundo ele, existem outros deveres do Poder Público para com a educação que não se limitam ao acesso obrigatório e gratuito, tais quais os descritos no próprio art. 208 da Constituição e repetidos pela Lei de Diretrizes e Bases - LDB, em seu art. $4^{\circ}$.

De fato, o acesso deve garantido a todo o sistema educacional, visto ser a educação um direito em contínuo desenvolvimento, que acompanha o homem ao longo de sua vida, o humanizando.

\section{b. Lei de Diretrizes e Bases}

A Lei n. 9.394, de 20.12.96, Lei de Diretrizes e Bases da Educação Nacional, também chamada "Lei Darcy Ribeiro", é, conforme expressão de Nina

\footnotetext{
${ }^{76}$ REALE, Miguel. Lições Preliminares de Direito, 16 ${ }^{\mathrm{a}}$. Ed. São Paulo: Saraiva, 1988, p. 269.

${ }^{77}$ LIBERATI, Wilson Donizeti. "Conteúdo material do direito à educação (208-260)". In. LIBERATI, Wilson Donizeti (org.). Direito à educação: Uma questão de justiça. São Paulo: Malheiros, 2004. p. 211.
} 
Ranieri, o "eixo jurídico da organização do ensino no País"78. Ela vem para regulamentar as linhas traçadas pela Constituição Federal, pois disciplina a educação escolar (da infância à superior), define incumbências (a jurisdição e a forma de relacionamento dos Sistemas de Ensino), além de tratar da gestão democrática do ensino público, da autonomia das escolas, dos níveis e modalidades de educação e de ensino, dos recursos financeiros, entre outros temas de igual importância.

A LDB é considerada, por diversos autores, o marco sistematizador das mudanças propostas à época de sua tramitação, sobretudo por sua flexibilidade, descentralização e avaliação ${ }^{79}$.

Ao regulamentar os dispositivos constitucionais referentes à educação, ela trata da escolarização básica de adultos (no presente caso, de jovens que cumprem MSE de privação de liberdade) na Seção V do Capítulo II, "Educação Básica", que obriga aos sistemas de ensino garantir cursos e exames que proporcionem oportunidades educacionais apropriadas aos interesses, condições de vida e trabalho dos jovens e adultos; e determina que o acesso e a permanência destes na escola devem ser viabilizados e estimulados por ações integradas dos poderes públicos.

Sendo a educação um direito extensivo a todos, e dever do Estado, ela deve ser fornecida de "modo a permitir a completitude da finalidade do Estado de proporcionar o bem-estar de todos ${ }^{\prime 80}$, de modo que a LDB dispõe em seu art. $1^{\circ}$ que “educação abrange os processos formativos que se desenvolvem na vida familiar, na convivência humana, no trabalho, nas instituições de ensino e pesquisa, nos movimentos sociais e organizações da sociedade civil e nas manifestações culturais."

Temos, assim, que o ensino é um gênero da educação, conforme nos mostra RANIERI $^{81}$ :

Os processos formativos, por sua vez, se ministrados por instituições escolares, constituem o "ensino", que se especifica de acordo com o seu nível ou modalidade, e a natureza jurídica pública ou privada do mantenedor. No texto constitucional, o ensino como processo formativo escolar é, em consequência, espécie do gênero "educação". Incluem-se nesta definição os

\footnotetext{
${ }^{78}$ RANIERI, Nina Beatriz Stocco, 2000. Educação superior, direito e Estado na lei de diretrizes e bases (Lei n. 9.394/96), São Paulo, EDUSP/FAPESP, p. 25

79 SARI, Marisa Timm. “A organização da Educação Nacional”. (67-120). In. LIBERATI, Wilson Donizeti (org.). Direito à educação: Uma questão de justiça. São Paulo: Malheiros, 2004. p. 71-72.

${ }^{80}$ LIBERATI, Wilson Donizeti. "Conteúdo material do direito à educação" (208-260). In. LIBERATI, Wilson Donizeti (org.). Direito à educação: Uma questão de justiça. São Paulo: Malheiros, 2004. p. 215.

${ }^{81}$ RANIERI, Nina Beatriz Stocco. "O Estado Democrático de Direito e o Sentido da Exigência de Preparo da Pessoa para o Exercício da Cidadania, pela Via da Educação”. Tese (Livre-Docência) Faculdade de Direito da Universidade de São Paulo. São Paulo, 2009, p. 285.
} 
processos próprios de aprendizagem relacionados ao oferecimento de ensino fundamental às populações indígenas $\left(\right.$ art. $\left.210, \S 2^{\circ}\right)$.

Em seu título III, "Do Direito à Educação e do Dever de Educar”, a LDB é clara ao afirmar em seu artigo $4^{\text {o82 }}$ que:

Art. $4^{\circ} \mathrm{O}$ dever do Estado com educação escolar pública será efetivado mediante a garantia de:

I - ensino fundamental, obrigatório e gratuito, inclusive para os que a ele não tiveram acesso na idade própria;

II - universalização do ensino médio gratuito;

\section{$[\ldots]$}

VI - oferta de ensino noturno regular, adequado às condições do educando;

VII - oferta de educação escolar regular para jovens e adultos, com características e modalidades adequadas às suas necessidades e disponibilidades, garantindo-se aos que forem trabalhadores as condições de acesso e permanência na escola;

VIII - atendimento ao educando, no ensino fundamental público, por meio de programas suplementares de material didático-escolar, transporte, alimentação e assistência à saúde;

IX - padrões mínimos de qualidade de ensino, definidos como a variedade e quantidade mínimas, por aluno, de insumos indispensáveis ao desenvolvimento do processo de ensinoaprendizagem.

$[\ldots]$

Tendo em vista que:

o direito à educação um direito humano fundamental, essencial para o desenvolvimento humano, sem o qual não há qualquer chance de sobrevivência (física e intelectual - no que diz respeito à concorrência de trabalho e sua consequente qualificação técnico-profissional) ou, se houver, essa sobrevivência estará comprometida com a qualidade. ${ }^{83}$

\footnotetext{
${ }^{82}$ Com relação ao inciso VII do artigo $4^{\circ}$, o Conselho Nacional de Educação aprovou em 2000 o Parecer 11 e a Resolução 1, que fixam Diretrizes Curriculares Nacionais para a Educação de Jovens e Adultos, de modo a regulamentar alguns aspectos da LDB.

${ }^{83}$ LIBERATI, Wilson Donizeti. "Conteúdo material do direito à educação" (208-260). In. LIBERATI, Wilson Donizeti (org.). Direito à educação: Uma questão de justiça. São Paulo: Malheiros, 2004. p. 212.
} 
Não há que se questionar a possibilidade de acesso à educação para aqueles que não a tiveram na idade própria, bem como para aqueles que se encontram privados de liberdade, sob a tutela do Estado.

\section{c. Plano Nacional de Educação}

$\mathrm{O}$ art. 214 da Constituição Federal e a Lei de Diretrizes e Bases da Educação Nacional (LDB, art. $87, \S^{\circ}$ ) preveem a aprovação por lei do Plano Nacional de Educação (PNE). Este Plano deve ser fruto do debate dos representantes dos diversos partidos políticos e das entidades e órgãos educacionais que acompanharam sua tramitação, sendo previstas inclusive audiências públicas para dar maior legitimidade ao Plano, definido como um Plano de Estado e não de Governo, por ser decenal (2001 a 2010 e 2011 a 2020). Tal previsão visa minimizar a descontinuidade que caracteriza as políticas educacionais ${ }^{84}$, elegendo as prioridades norteadoras dessas políticas.

O plano contempla todos os níveis e modalidades de educação, bem como seu financiamento e gestão. Além disso, ele determina que Estados, Distrito Federal e Municípios elaborem planos decenais correspondentes, e prevê a realização de avaliações periódicas para o acompanhamento da implementação do Plano. Ele pressupõe ainda planos plurianuais de cada uma das esferas federativas para dar suporte à consecução de seus objetivos e metas.

Quando institucionalizados, faz-se necessário considerar as normas próprias dos Sistemas de Ensino da União, dos Estados, do Distrito Federal e dos Municípios. Estas são organizadas por SARI em dois subconjuntos, quais sejam:

As derivadas de atos do Poder Legislativo (Lei do Sistema de Ensino, Lei do Conselho de Educação, Lei da Gestão Democrática, Lei do Plano de Educação, Lei do plano de Carreira e Remuneração do Magistério etc.), as derivadas de atos do Poder Executivo - atos próprios (decretos e portarias) e atos de seu órgão normativo (pareceres e resoluções ou deliberações). ${ }^{85}$

Os órgãos normativos dos Sistemas de Ensino são os Conselhos de Educação que possuem funções normativas e consultivas no que se refere à legislação educacional, à sua interpretação e à sua aplicação.

${ }^{84}$ SARI, Marisa Timm. "A organização da Educação Nacional". (67-120). In. LIBERATI, Wilson Donizeti (org.). Direito à educação: Uma questão de justiça. São Paulo: Malheiros, 2004. p. 73-74.

${ }^{85}$ SARI, Marisa Timm. "A organização da Educação Nacional". (67-120). In. LIBERATI, Wilson Donizeti (org.). Direito à educação: Uma questão de justiça. São Paulo: Malheiros, 2004. p. 73-74. 
A Lei 10.172/2001 do Plano Nacional de Educação (PNE) definiu 26 metas prioritárias para o decênio 2001-2010, tais quais: alfabetizar em cinco anos dois terços da população analfabeta, visando superar o analfabetismo em uma década; assegurar, em cinco anos, a oferta do primeiro segmento do Ensino Fundamental para 50\% da população com mais de 15 anos que não tenha atingido este nível de escolaridade; atender no segundo segmento do Ensino Fundamental toda a população com mais de 15 anos que tenha concluído a etapa precedente; dobrar em cinco anos, e quadruplicar em dez anos, o atendimento de jovens e adultos no Ensino Médio ${ }^{86}$.

Entre tantas metas a serem realizadas, encontramos como sendo a $17^{\mathrm{a}}$ meta, implantar, em todas as unidades prisionais e estabelecimentos que atendam adolescentes e jovens em conflito com alei, programas de educação de nível fundamental e médio (EJA), assim como de formação profissional. Tal meta contempla outras como a $5^{\text {a }}$ (financiamento pelo MEC de material didático-pedagógico) e a $14^{\mathrm{a}}$ (oferta de programas de educação à distância); já que é obrigação estatal assegurar recursos do Tesouro e da Assistência Social para programas de renda mínima associados à educação, recursos da Saúde e Assistência Social para a educação infantil; recursos destinados à criação de condições de acesso da escola; e recursos do Trabalho para a qualificação dos trabalhadores.

Entretanto, apesar de o Plano Nacional de Educação ter sido elaborado em 2001, somente em março de 2005, ou seja, quatro anos depois da sua publicação, o Ministério da Educação anunciou que em parceria com o Ministério da Justiça e a Secretaria de Direitos Humanos da Presidência da República participaria da definição de projeto educativo destinado às populações carcerárias, o qual só foi efetivado em 2009, ou seja, oito anos depois.

$\mathrm{O}$ atual $\mathrm{PNE}^{87}$, para o decênio 2011-2020, definiu 20 metas prioritárias, tais quais:

Meta 2: Criar mecanismos para o acompanhamento individual de cada estudante do ensino fundamental.

Meta 3: Universalizar, até 2016, o atendimento escolar para toda a população de 15 a 17 anos e elevar, até 2020, a taxa líquida de matrículas no ensino médio para $85 \%$, nesta faixa etária.

\footnotetext{
${ }^{86}$ GRACIANO Mariângela. “A educação como Direito Humano: A escola na prisão”. USP Faculdade de Educação. Programa de Pós-Graduação em Educação (Mestrado). São Paulo, 2005.p. 33.

${ }^{8787}$ Sitio eletrônico do Senado: http://www12.senado.gov.br/noticias/materias/2012/10/22/plano-nacionalde-educacao-apresenta-19-metas - consulta realizada em 15.12.2012.
} 
Meta 6: Oferecer educação em tempo integral em 50\% das escolas públicas de educação básica.

Meta 7: Atingir as médias nacionais para o Ideb já previstas no Plano de Desenvolvimento da Educação (PDE)

Meta 8: Elevar a escolaridade média da população de 18 a 24 anos de modo a alcançar mínimo de 12 anos de estudo para as populações do campo, da região de menor escolaridade no país e dos $25 \%$ mais pobres, bem como igualar a escolaridade média entre negros e não negros, com vistas à redução da desigualdade educacional.

Meta 9: Elevar a taxa de alfabetização da população com 15 anos ou mais para 93,5\% até 2015 e erradicar, até 2020, o analfabetismo absoluto e reduzir em 50\% a taxa de analfabetismo funcional.

Meta 10: Oferecer, no mínimo, $25 \%$ das matrículas de educação de jovens e adultos na forma integrada à educação profissional nos anos finais do ensino fundamental e no ensino médio.

Meta 11: Duplicar as matrículas da educação profissional técnica de nível médio, assegurando a qualidade da oferta.

Meta 12: Elevar a taxa bruta de matrícula na educação superior para $50 \%$ e a taxa líquida para $33 \%$ da população de 18 a 24 anos, assegurando a qualidade da oferta.

Meta 19: Garantir, mediante lei específica aprovada no âmbito dos estados, do Distrito Federal e dos municípios, a nomeação comissionada de diretores de escola vinculada a critérios técnicos de mérito e desempenho e à participação da comunidade escolar.

Meta 20: Ampliar progressivamente o investimento público em educação até atingir, no mínimo, o patamar de 7\% do Produto Interno Bruto (PIB) do país.

Além das 10 diretrizes objetivas e das 20 metas, o PNE apresenta estratégias específicas de concretização das ambiciosas metas do atual decênio, visto que o atual PNE foi aprovado por unanimidade pela Câmara dos Deputados, apenas em 16 de outubro de 2012 (após 18 meses de tramitação), e ainda será encaminhado para exame do Senado Federal.

\section{d. Conselho Nacional de Educação}

O Conselho Nacional de Educação tem como missão a "busca democrática de alternativas e mecanismos institucionais que possibilitem, no âmbito de sua esfera de 
competência, assegurar a participação da sociedade no desenvolvimento, aprimoramento e consolidação da educação nacional de qualidade". ${ }^{88}$

O CNE é regulamentado pela lei federal 9.131/95 sancionada pelo então presidente Fernando Henrique Cardoso, que alterou dispositivos da Lei ${ }^{\circ} 4.024$, de 20 de dezembro de 1961. O atual CNE é tido como órgão colegiado integrante do Ministério da Educação.

As atribuições do Conselho são normativas, deliberativas e de assessoramento ao Ministro de Estado da Educação. Assim, lhe cumpre formular e avaliar a política nacional de educação, buscando o aprimoramento da legislação educacional e a participação da sociedade.

O Conselho e as Câmaras exercem as atribuições conferidas pela Lei 9.131/95, tal qual a emissão de pareceres e decisão de assuntos que lhe são pertinentes.

Para saber um pouco mais do histórico do Conselho Nacional de Educação, cumpre-nos transcrever a seguinte passagem do portal do MEC:

A primeira tentativa de criação de um Conselho na estrutura da administração pública, na área de educação, aconteceu na Bahia, em 1842, com funções similares aos "boards" ingleses e, em 1846, a Comissão de Instrução Pública da Câmara dos Deputados propôs a criação do Conselho Geral de Instrução Pública.

A ideia de um Conselho Superior somente seria objetivada em 1911 (Decreto $n^{o}$ 8.659, de 05/04/1911) com a criação do Conselho Superior de Ensino.

A ele seguiram-se o Conselho Nacional de Ensino (Decreto ${ }^{\circ}$ 16.782-A, de 13/01/1925), o Conselho Nacional de Educação (Decreto $\mathrm{n}^{\circ}$ 19.850, de 11/04/1931), o Conselho Federal de Educação e os Conselhos Estaduais de Educação (Lei no 4.024, de 20/12/1961), os Conselhos Municipais de Educação (Lei no 5692, de 11/08/1971) e, novamente, Conselho Nacional de Educação (MP $\mathrm{n}^{\circ}$ 661, de 18/10/94, convertida na Lei $\mathrm{n}^{\circ}$ 9.131/95). ${ }^{89}$

Dentre os compromissos do Conselho podemos citar:

1- Consolidar a identidade do Conselho Nacional de Educação como Órgão de Estado, identidade esta afirmada e construída na prática cotidiana, nas ações, intervenções e interações com os demais sistemas de ensino.

\footnotetext{
${ }^{88}$ Site: http://portal.mec.gov.br/ Acesso em 13.06.2011.

${ }^{89}$ Site: http://portal.mec.gov.br/ Acesso em 13.06.2011.
} 
2- Participar do esforço nacional comprometido com a qualidade social da educação brasileira, cujo foco incide na escola da diversidade, e para a diversidade, tendo o PNE e o PDE como instrumentos de conquista dessa prioridade.

\section{$[\ldots]$}

4- Consolidar a estrutura e diversificar o funcionamento do CNE. Não queremos que ele responda apenas às demandas, mas que se constitua em espaço de fortalecimento de suas relações com os demais sistemas de ensino e com os segmentos sociais, espaço de estudos para as comissões bicamerais, audiências públicas, fóruns de debates, sempre cuidando da dotação de infraestrutura material necessária e do quadro de pessoal próprio.

5- Instaurar um diálogo efetivo, articulado e solidário, com todos os sistemas de ensino (em nível federal, estadual e municipal), em compromisso com a Política Nacional de Educação, em regime de colaboração e de cooperação. Talvez este se constitua no desafio maior para o CNE. ${ }^{90}$

Um outro órgão ligado ao CNE é a Câmara de Educação básica, cujas atribuições, entre outras, consiste em analisar e emitir pareceres sobre procedimentos e resultados de processos de avaliação da educação infantil, fundamental, média, profissional e especial; deliberar sobre diretrizes curriculares propostas pelo Ministério da Educação; acompanhar a execução do Plano Nacional de Educação. Estas atribuições, somadas aos objetivos do CNE, principalmente os constantes do item 4, referente à resposta às demandas educacionais e ao fortalecimento de suas relações com os demais sistemas de ensino e com os segmentos sociais, são consonantes com o que se pretende na educação prisional, que é a articulação dos sistemas de ensino formal com a prática de ensino dentro das prisões (se é que podemos classificá-la como um sistema de ensino).

\section{e. Secretaria da Educação do Estado de São Paulo}

A criação da Secretaria da Educação do Estado de São Paulo se deu no início da década de 30, quando se começou a pensar a estruturação de uma rede de educação que se utilizasse de políticas específicas para a formação de professores e abastecimento das escolas. Antes a educação de São Paulo era conduzida Secretaria de Interior através da Diretoria de Instrução Pública.

\footnotetext{
${ }^{90}$ Site: http://portal.mec.gov.br/ Acesso em 13.06.2012.
} 
"Um dos principais resultados desse movimento é a primeira reforma de instrução pública, também conhecida como a "grande reforma de 20". A reforma realizada em São Paulo, que propunha a modernização administrativa e a reestruturação da rede física, serviu como exemplo para que outros Estados também iniciassem mudanças na área." ${ }^{.1}$

O crescimento da cidade de São Paulo e o novo cenário político apresentado pela revolução de 1930 auxiliaram nesta reestruturação, de modo que em 3 de março de 1931 foi criada, pelo Decreto $n^{\circ}$ 4.917, a Secretaria da Educação. São evidentes as melhoras ocorridas nas áreas administrativas e o avanço das discussões pedagógicas com a reforma que ficou conhecida como reforma Fernando de Azevedo. Foram tantos avanços, que a pasta da nova secretaria educação se manteve sob a mesma estrutura até 1947.

Atualmente a Secretaria se guia pelo disposto no decreto . $^{\circ} 57.141$ de 18 de julho de 2011, que a reorganizou:

"Em 2012 teve início a reestruturação de sua formação básica, que conta agora com dois órgãos vinculados, sendo eles o Conselho Estadual de Educação (CEE) e a Fundação para o Desenvolvimento da Educação (FDE) e seis Coordenadorias: Escola de Formação e Aperfeiçoamento de Professores "Paulo Renato Costa Souza" (EFAP); Coordenadoria de Gestão da Educação Básica (CGEB); Coordenadoria de Informação, Monitoramento e Avaliação Educacional (CIMA); Coordenadoria de Infraestrutura e Serviços Escolares (CISE); Coordenadoria de Gestão de Recursos Humanos (CGRH); Coordenadoria de Orçamento e Finanças (COFI)." ${ }^{.92}$

O novo modelo adotado pelo então governador do Estado de São Paulo Geraldo Alckmin foi pensado em parceria com a Fundação para o Desenvolvimento Administrativo (Fundap) e transferiu tarefas de professores para profissionais específicos, auxiliando a organização interna das coordenadorias. Segundo dados do sitio eletrônico da Secretaria da Educação do Estado de São Paulo esta

"possui a maior rede de ensino do Brasil, com 5,3 mil escolas, 230 mil professores, 59 mil servidores e mais de quatro milhões de alunos. Até 2011, a SEE esteve organizada em sete órgãos centrais e dois órgãos vinculados. ${ }^{, 93}$

Vemos que a educação no estado de São Paulo é fornecida através de uma forte estrutura educacional. Tal estrutura também é responsável pela educação-formal

\footnotetext{
${ }^{91}$ Site: http://portal.mec.gov.br/ Acesso em 13.06.2012.

${ }^{92}$ Site: http://portal.mec.gov.br/ Acesso em 13.06.2012.

${ }^{93}$ Site: http://portal.mec.gov.br/ Acesso em 13.06.2012.
} 
dos jovens que se encontram em privação de liberdade, por isso a importância de sua análise.

\section{Tratados e Declarações Internacionais e o Direito à Educação}

O Brasil - signatário de diversas declarações e pactos internacionais de proteção aos direitos humanos e que elencou em sua Constituição Federal o direito à educação, ao lado de outros direitos sociais, regulamentando-o através de uma vasta quantidade de leis, diretrizes, normas técnicas e outros instrumentos normativos acabou por conferir à educação a condição de exigibilidade e justiciabilidade ${ }^{94}$.

Nesse sentido, é importante considerar o direito humano à educação não apenas no contexto apresentado pelo PIDESC, mas também sob a ótica de outros instrumentos de direitos humanos, tais como o protocolo de San Salvador, a convenção relativa à luta contra as discriminações na esfera do ensino, e a Declaração Mundial sobre Educação para todos.

\section{a. Declaração Universal dos Direitos Humanos}

A Declaração Universal dos Direitos Humanos é tida como um acontecimento histórico visto ser a primeira a afirmar o papel dos direitos humanos na convivência coletiva. Ela veio por alterar a lógica da paz de Westfália (1648) que se baseava nas "relações de coexistência e conflito entre entes soberanos num sistema

\footnotetext{
${ }^{94}$ Existem remédios jurisdicionais (nacionais e internacionais), mas também outros mecanismos de exigência, como o departamento do ombudsman (Procuradoria dos Direitos Humanos, Defensoria do Povo etc.), as Comissões de Direitos Humanos dos sistemas universal ou regionais de direitos humanos, os procedimentos convencionais e extraconvencionais das Nações Unidas e dos sistemas regionais de proteção aos direitos humanos, e controles de serviço ou gestão institucional, entre outros. Os instrumentos convencionais são os instrumentos do direito internacional que por sua natureza, sua adoção, sua ratificação e seu grau de compromisso e composição jurídica multilateral obrigam os Estados a respeitarem os direitos e obrigações contidas no texto de uma convenção, que normalmente zela e promove os direitos por meio de órgãos criados por esse mesmo instrumento (como, por exemplo, o Comitê sobre os Direitos das Crianças). Os mecanismos não convencionais não são resultado de uma convenção ou tratado, mas sim produto do consenso ou decisão de certas instâncias dos sistemas universal ou regionais de direitos humanos, tais como as relatorias especiais ou os grupos de trabalho de composição aberta. A existência e a cobertura de todas essas formas protetoras é o que pode garantir a acessibilidade, sustentabilidade e efetividade dos recursos de proteção e defesa que legalmente deveriam ser complementados pela implementação de políticas públicas destinadas à concretização dos direitos humanos. (HADDAD e GRACIANO, 2006. p. 52.)
} 
internacional de natureza intraestatal"95, não apreciando possíveis ingerências dos Estados.

Dentre as tentativas de pactos sociais, temos a Sociedade das Nações (1919) que procurou "institucionalizar a comunidade internacional criando um tertius interpartes por meio de uma organização internacional" ${ }^{\text {96 }}$, porém nesta o papel dos direito humanos ainda era restringido.

Posteriormente, a Carta da ONU (1945) figurou como um terceiro cuja amplitude de organização internacional auxiliou na institucionalização dos direitos humanos e inserindo sua temática na construção da ordem mundial. Como desdobramento da Carta da ONU, temos a Declaração Universal de 1948, o primeiro texto internacional a tratar, de forma ampla, a importância dos direitos humanos, o que representa internacionalmente um evento inaugural. Importante frisar que esta passagem teve uma série de influencias como a Declaração da Independência dos EUA (1776), as Declarações de Direito da Revolução Francesa, a Constituição Mexicana, a Constituição Alemã de Weimar, entre outras.

Aproximadamente dois séculos antes (fins do XVIII, inícios do XIX), Kant já sistematizara o pensamento que mais tarde apareceria na internacionalização dos direitos humanos visto conceber o ser humano como um fim em si mesmo e não o meio. Tanto que enfatiza em sua obra que a "história humana só pode ter unidade, regularidade e continuidade teleológica quando considerada sob o ângulo universal"97, sendo a proposição de um direito cosmopolita ${ }^{98}$ a grande inovação de Kant no que se refere ao plano internacional.

Assim, percebemos que é a sensibilidade em relação à violação dos direitos que está na raiz do evento histórico único da Declaração Universal, podendo ser analisada a partir das fontes materiais (fenômenos sociais, econômicos ou científicos que modificam e/ou criam normas na ordem jurídica). Tais fontes obedecem, no plano internacional, uma lógica mais delimitada, que não foi como a das agendas internas.

\footnotetext{
${ }^{95}$ LAFER, Celso. "Declaração universal dos Direitos Humanos (1948)”, In: MAGNOLI, Demétrio (org.). História da paz: os tratados que desenharam o planeta. São Paulo: Contexto, 2008. Vários Autores.

${ }^{96}$ LAFER, Celso. "Declaração universal dos Direitos Humanos (1948)", In: MAGNOLI, Demétrio (org.). História da paz: os tratados que desenharam o planeta. São Paulo: Contexto, 2008. Vários Autores.

${ }^{97}$ LAFER, Celso. "Declaração universal dos Direitos Humanos (1948)”, In: MAGNOLI, Demétrio (org.). História da paz: os tratados que desenharam o planeta. São Paulo: Contexto, 2008. Vários Autores.

${ }^{98}$ No séc. XX, o pacto da Sociedade das Nações apreciou de forma circunscrita os direitos humanos, tratando de diversos grupos como indígenas, mulheres, crianças, etc. Mais um regime concebido pela Sociedade é das minorias havidas do desmembramento de impérios, o que gerou um grande número de displaced people expelidos do conjunto Povo-Estado-Território. A negação dos direitos humanos acabou gerando arbítrio, sendo a única maneira de efetivar o "direito a ter direitos"a tutela internacional.
} 


\section{Um "Direito Novo" e sua lógica}

Em 6.01.1941, Franklin Delano Roosevelt, então presidente dos EUA, proferiu um discurso no qual afirmava a necessidade de um mundo balizado por quatro diferentes tipos de liberdade: 1. Expressão; 2. Religião; 3. De viver ao abrigo da necessidade; e 4. De viver sem medo. Somente em 1948, sob a presidência de Eleanor Roosevelt, viúva do presidente, a nova Comissão das Nações Unidas para os Direitos Humanos acabou por captar a atenção do mundo, através da Declaração das Nações Unidas que expressava seu credo na preservação dos direitos humanos. A Declaração Universal de 1948 foi a primeira expressão de uma proposta orientadora para a consecução de objetivos comuns, sendo produto da cooperação intelectual e moral de diversas nações ${ }^{99}$.

Analisando os dispositivos da Declaração, percebemos que ela considera a paz como um valor e identifica uma direção no sentido do pacifismo ativo. Importante frisar que ela não é a soma de Declarações nacionais nem estas ampliadas para escala mundial.

A Declaração, conforme qualificação de $\operatorname{CASSIN}^{100}$, é o pórtico do templo dos direitos humanos, sendo sua base o princípio da generalização (calcado na igualdade e dignidade de direitos). Sobre este pórtico existem 4 colunas: 1. Direitos e liberdades de ordem pessoal; 2. Direitos dos indivíduos nos relacionamentos com grupos; 3. Faculdades espirituais, públicas e direitos políticos fundamentais; 4. Direitos econômicos, sociais e culturais.

Por não ter força de lei internacional e sim de recomendação, à declaração era juridicamente atribuída a eficácia de norma costumeira do Direito Internacional Público, de modo que com o passar do tempo, ela tornou-se usual no processo de criação destas normas.

\footnotetext{
${ }^{99}$ Foram padrinhos da Declaração, sem o quais ela não terminado adequadamente, Eleanor Roosevelt, René Cassin, Charles Malik, Peng-chan Chung John P. Humphrey e Hernán Santa Cruz. Estes, mais do que homogeneizadores, eram universalistas e "acreditavam na unidade do gênero humano e entendiam que processos de experienciar, compreender e julgar eram capazes de a todos conduzir ao entendimento e à aceitação de algumas verdades básicas" (LAFER, LAFER, Celso. "Declaração universal dos Direitos Humanos (1948)", In: MAGNOLI, Demétrio (org.). História da paz: os tratados que desenharam o planeta. São Paulo: Contexto, 2008. Vários Autores.).

${ }^{100}$ LAFER, Celso. "Declaração universal dos Direitos Humanos (1948)", In: MAGNOLI, Demétrio (org.). História da paz: os tratados que desenharam o planeta. São Paulo: Contexto, 2008. Vários Autores.
} 


\section{A Declaração e o Direito à Educação}

O artigo 26 da Declaração Universal dos Direitos Humanos determina que:

1. Toda pessoa tem direito à educação. A educação será gratuita pelo menos nos graus elementares e fundamentais. O ensino elementar é obrigatório. $\mathrm{O}$ ensino técnico e profissional deve ser generalizado; o acesso aos estudos superiores deve ser assegurado a todos, em plenas condições de igualdade, em função do mérito.

Além disso, os objetivos enunciados na Declaração Universal dos Direitos Humanos de 1948 também tratam da educação ao determinar que:

A instrução será orientada no sentido do pleno desenvolvimento da personalidade humana e do fortalecimento do respeito pelos direitos do homem e pelas liberdades fundamentais (Item 2, Artigo 26).

O que nos mostra o caráter transformador da educação, e mais uma vez reforça que toda pessoa tem direito à educação.

\section{b. Pacto Internacional dos Direitos Econômicos, Sociais e Culturais}

Por sua vez, o Pacto Internacional dos Direitos Econômicos, Sociais e Culturais (PIDESC), adotado pela Resolução n. 2.200-A (XXI) da Assembleia Geral das Nações Unidas em 16.12.1966 e ratificado pelo Estado brasileiro, entrou em vigor no Brasil em 24.01.1992, promulgado pelo Decreto-lei n.591, de 06.07.1992. Em seu artigo 13 este dispõe que:

1. Os Estados-partes no presente pacto reconhecem o direito de toda à pessoa à educação. Concordam em que a educação deverá visar ao pleno desenvolvimento da personalidade humana e do sentido de dignidade e a fortalecer o respeito pelos direitos humanos e liberdades fundamentais. Concordam ainda que a educação deverá capacitar todas as pessoas a participar efetivamente de uma sociedade livre, favorecer a compreensão, a tolerância e a amizade entre todas as nações e entre todos os grupos raciais, étnicos ou religiosos e promover as atividades das Nações Unidas em prol da manutenção da paz.

Ao assegurar o direito à educação no PIDESC, mais especificamente em seu item "d", alínea 2, artigo 13, quando versa sobre a educação de jovens e adultos, o pacto não faz menção à "obrigatoriedade", "gratuidade" ou "progressividade" na implementação desta modalidade. 
Dever-se-á fomentar e intensificar, na medida do possível, a educação de base para aquelas pessoas que não receberam educação primária ou não concluíram o ciclo completo de educação primária.

COMPARATO chama a atenção para a ambiguidade dos termos "educação primária" e "educação secundária", que não trazem consigo a especificação das séries ou período escolar - correspondentes. Isto é particularmente importante porque o Pacto determina obrigatoriedade e gratuidade apenas para a educação primária, e esta varia de configuração em cada País. No Brasil, o número de anos obrigatórios de educação pública gratuita ampliou-se de 4 para 8 anos em 1971 e, em 1996, este período teve sua denominação alterada de "Ensino de $1^{\circ}$ grau" para "Ensino Fundamental". 101

Além da ambiguidade acima apontada, em relação à educação de jovens e adultos, o Pacto fala em "educação de base" sem, contudo, explicitar seu significado.

\title{
c. Declaração de Hamburgo
}

A Declaração de Hamburgo, assinada ao final da $5^{\text {a }}$ Conferência Internacional sobre Educação de Jovens e Adultos (Confintea V) realizada na Alemanha em julho de 1997, avança em relação ao reconhecimento do direito à educação, formal e não-formal, ao afirmar o direito à aprendizagem a todas as pessoas, destacando os grupos historicamente excluídos em seu item 11 "Alfabetização de adultos": "A preocupação mais urgente é estimular oportunidades de aprendizagem a todos, em particular, os marginalizados e excluídos".

Em seu "Plano de Ação para o futuro", ela também trata da educação das pessoas encarceradas de forma explícita no "Tema 8", cujo item 43 afirma a educação como um direito universal que tem sido negado a muitos grupos, entre eles "os presos" e, dando consequência a esta constatação, prevê, no item 47:

\begin{abstract}
Reconhecer o direito de todas as pessoas encarceradas à aprendizagem: a) proporcionando a todos os presos informação sobre os diferentes níveis de ensino e formação, e permitindolhes acesso aos mesmos; b) elaborando e implementando nas prisões programas de educação geral com a participação dos presos, a fim de responder a suas necessidades e aspirações em matéria de aprendizagem; c) facilitando que organizações não governamentais, professores e outros responsáveis por atividades educativas trabalhem nas prisões, possibilitando assim o acesso das pessoas encarceradas aos estabelecimentos
\end{abstract}

101 COMPARATO, Fábio Konder. A afirmação histórica dos direitos humanos. São Paulo, Editora Saraiva, 2003. 
docentes e fomentando iniciativas para conectar os cursos oferecidos na prisão aos realizados fora dela ${ }^{102}$.

Percebemos, assim, que ao reconhecer o direito de todas as pessoas encarceradas à aprendizagem, a Declaração de Hamburgo afirma a fundamentalidade do direito à educação.

\section{d. Declaração Mundial sobre Educação para todos}

Em 1990, em Jomtien, Tailândia, realizou-se a Conferência Mundial sobre Educação para Todos e Satisfação das Necessidades Básicas de Aprendizagem donde se aprovou a "Declaração Mundial sobre Educação para todos". Nesta indicou-se um plano de ação para satisfazer as necessidades básicas de aprendizagem, certificando seus objetivos, quais sejam:

\section{ARTIGO 1. SATISFAZER AS NECESSIDADES BÁSICAS DE APRENDIZAGEM}

1. Cada pessoa - criança, jovem ou adulto - deve estar em condições de aproveitar as oportunidades educativas voltadas para satisfazer suas necessidades básicas de aprendizagem. Essas necessidades compreendem tanto os instrumentos essenciais para a aprendizagem (como a leitura e a escrita, a expressão oral, o cálculo, a solução de problemas), quanto os conteúdos básicos da aprendizagem (como conhecimentos, habilidades, valores e atitudes), necessários para que os seres humanos possam sobreviver, desenvolver plenamente suas potencialidades, viver e trabalhar com dignidade, participar plenamente do desenvolvimento, melhorar a qualidade de vida, tomar decisões fundamentadas e continuar aprendendo. A amplitude das necessidades básicas de aprendizagem e a maneira de satisfazê-las variam segundo cada país e cada cultura, e, inevitavelmente, mudam com o decorrer do tempo.

2. A satisfação dessas necessidades confere aos membros de uma sociedade a possibilidade e, ao mesmo tempo, a responsabilidade de respeitar e desenvolver a sua herança cultural, linguística e espiritual, de promover a educação de outros, de defender a causa da justiça social, de proteger o meio-ambiente e de ser tolerante com os sistemas sociais, políticos e religiosos que difiram dos seus, assegurando respeito aos valores humanistas e aos direitos humanos comumente aceitos, bem como de trabalhar pela paz e pela solidariedade internacionais em um mundo interdependente.

$\overline{102}$ Declaração de Hamburgo, 1997, tema 8, item 47. 
3. Outro objetivo, não menos fundamental, do desenvolvimento da educação, é o enriquecimento dos valores culturais e morais comuns. É nesses valores que os indivíduos e a sociedade encontram sua identidade e sua dignidade.

4. A educação básica é mais do que uma finalidade em si mesma. Ela é a base para a aprendizagem e o desenvolvimento humano permanentes, sobre a qual os países podem construir, sistematicamente, níveis e tipos mais adiantados de educação e capacitação.

A partir destes objetivos podemos observar o quão necessária é a educação para sobrevivência, uma vez que só ela desenvolve plenamente as potencialidades do ser humano, auxiliando-o a viver e a trabalhar com dignidade, a desenvolver-se. Os demais artigos passam a tratar da expansão desta visão de educação (Art. 2 Expandir o enfoque) como a necessidade de universalizar o acesso à educação e promover a equidade através da atenção na aprendizagem; da ampliação dos meios e do raio de ação da educação básica; da promoção de um ambiente adequado à aprendizagem; e do fortalecimento de alianças. Estes itens estão detalhados nos artigos de 3 a 7.

Os artigos 8 ao 10 tratam dos requisitos desta sonhada "educação para todos", tais quais mobilização de recursos e o fortalecimento da solidariedade internacional. Deste modo, a declaração firma o compromisso coletivo de cooperação, para que em se tomando todas as medidas necessárias à consecução dos objetivos de educação para todos, possa-se concretizar o que denominam urgente empreendimento.

\section{Políticas públicas educacionais e jurisprudência}

Para que direitos sociais sejam garantidos e efetivados, são necessários programas de ação, planejamento e investimento, consolidados por meio de políticas públicas, no presente caso, políticas públicas educacionais. O conceito de política como programa de ação apenas recentemente passou a ser tratado pela teoria jurídica. Assim, em que pese a política se distinguir das normas e dos atos, ela precisa reconhecê-los como seus componentes, que se unificam pela sua finalidade.

Mas afinal, o que são políticas públicas? Segundo definiç̧ão de BUCCI, elas se constituem como

um programa ou quadro de ação governamental, porque consiste num conjunto de medidas articuladas (coordenadas), cujo escopo é dar impulso, isto é, movimentar a máquina do 
governo, no sentido de realizar algum objetivo de ordem pública ou, na ótica dos juristas, concretizar um direito ${ }^{103}$

\section{Por sua vez, CANELA as classifica como}

o conjunto de atividades do Estado tendentes a seus fins, de acordo com metas a serem atingidas. Trata-se de um conjunto de normas (Poder Legislativo), atos (Poder Executivo) e decisões (Poder Judiciário) que visam à realização dos fins primordiais do Estado - e complementa - como toda atividade política (políticas públicas) exercida pelo Legislativo e pelo Executivo deve compatibilizar-se com a Constituição, cabe ao Poder Judiciário analisar, em qualquer situação e desde que provocado, o que se convencionou chamar 'atos de governo' ou 'questões políticas', sob o prisma do atendimento aos fins do Estado (art. $3^{\circ}$ da CF). ${ }^{104}$

O juízo de constitucionalidade de políticas públicas acaba por exigir uma normatização referente à forma processual da demanda, da legitimidade das partes e da competência judiciária. Atualmente, o posicionamento dos tribunais brasileiros avançou no que concerne à efetivação de direitos sociais, tanto que podemos citar o reconhecimento pelo STF do dever do Estado de fornecer gratuitamente medicação aos portadores do vírus HIV. Dentre as decisões paradigmáticas do Supremo, temos que citar a ADPF 45-9, na qual em decisão monocrática o Ministro Celso de Mello assim se posicionou:

É certo que não se inclui, ordinariamente, no âmbito das funções institucionais do Poder Judiciário - e nas desta Suprema Corte, em especial - a atribuição de formular e de implementar políticas públicas (JOSÉ CARLOS VIEIRA DE ANDRADE, "Os Direitos Fundamentais na Constituição Portuguesa de 1976", p. 207, item n. 05, 1987, Almedina, Coimbra), pois, nesse domínio, o encargo reside, primariamente, nos Poderes Legislativo e Executivo. Tal incumbência, no entanto, embora em bases excepcionais, poderá atribuir-se ao Poder Judiciário, se e quando os órgãos estatais competentes, por descumprirem os encargos políticojurídicos que sobre eles incidem, vierem a comprometer, com tal comportamento, a eficácia e a integridade de direitos individuais e/ou coletivos impregnados de estatura constitucional, ainda que derivados de cláusulas revestidas de conteúdo programático. Cabe assinalar, presente esse contexto consoante já proclamou esta Suprema Corte - que o caráter programático das regras inscritas no texto da Carta Política "não

${ }^{103}$ BUCCI, Maria Paula Dallari. "O conceito de política pública em direito”. In. BUCCI, Maria Paula Dallari (org.) Políticas Públicas: Reflexões sobre o conceito Jurídico. São Paulo: Saraiva, 2006. p. 14.

${ }^{104}$ CANELA, Oswaldo. Jr. In. GRINOVER, Ada Pellegrini. O controle de políticas públicas pelo Poder Judiciário. O processo: estudos e pareceres. $2^{\text {a }}$ edição revisada e ampliada. São Paulo: DPJ Editora, 2009. p. 39. 
pode converter-se em promessa constitucional inconsequente, sob pena de o Poder Público, fraudando justas expectativas nele depositadas pela coletividade, substituir, de maneira ilegítima, o cumprimento de seu impostergável dever, por um gesto irresponsável de infidelidade governamental ao que determina a própria Lei Fundamental do Estado" (RTJ 175/1212-1213, Rel. Min. CELSO DE MELLO). [...] A meta central das Constituições modernas, e da Carta de 1988 em particular, pode ser resumida, como já exposto, na promoção do bem-estar do homem, cujo ponto de partida está em assegurar as condições de sua própria dignidade, que inclui, além da proteção dos direitos individuais, condições materiais mínimas de existência. Ao apurar os elementos fundamentais dessa dignidade (o mínimo existencial), estar-se-ão estabelecendo exatamente os alvos prioritários dos gastos públicos. Apenas depois de atingilos é que se poderá discutir, relativamente aos recursos remanescentes, em que outros projetos se deverá investir. O mínimo existencial, como se vê, associado ao estabelecimento de prioridades orçamentárias, é capaz de conviver produtivamente com a reserva do possível. (grifei) [...].

Importante mencionar que os direitos, objetivos fundamentais do Estado, cuja implementação exige políticas públicas, possuem um núcleo central que assegura o mínimo existencial necessário à garantia da dignidade humana. Neste núcleo temos o direito à educação fundamental, à saúde, ao saneamento básico, ao acesso à Justiça etc.

Inaceitável, é assim, a legação do poder Público de falta de recursos para a implementação das políticas públicas, devendo, devendo esta ser provada pela própria administração (através da inversão do ônus da prova - art. $6^{\circ}$, VIII do CDC ou da distribuição dinâmica do ônus da prova flexibilizando o art.333 do CPC). Cabendo que

o Judiciário, em face da insuficiência de recursos e de falta de previsão orçamentária, devidamente comprovadas, determinará ao Poder Público que faça constar da próxima proposta orçamentária a verba necessária à implementação da política pública. E, como a lei orçamentária não é vinculante, permitindo a transposição de verbas, o Judiciário ainda deverá determinar, em caso de descumprimento do orçamento, a obrigação de fazer consistente na implementação de determinada política pública. ${ }^{105}$

Também no Tribunal de São Paulo tal posicionamento é adotado, vejamos:

AÇÃO CIVIL PÚBLICA - LEGITIMIDADE -
INTERFERENCIA NO PODER EXECUTIVO -
INEXISTÊNCIA - TRATANDO-SE DE ATENDIMENTO
SOCIAL PREVISTO NA CONSTITUIÇÃO DA REPÚBLICA,
É DE SE RECONHECER A EXISTENNCIA DE DIREITO

105 GRINOVER, Ada Pellegrini. O controle de políticas públicas pelo Poder Judiciário. O processo: estudos e pareceres. $2^{a}$ edição revisada e ampliada. São Paulo: DPJ Editora, 2009. p. 48. 
DIFUSO A SER TUTELADO POR AÇÃO CIVIL PÚBLICA. A DETERMINAÇÃ̃O PARA IMPLEMENTAÇÃO DE POLÍTICA PÚBLICA, JÁ PREVISTA NA CONSTITUIÇÃO DA REPÚBLICA, NÃO CARACTERIZA INGERÊNCIA NO PODER EXECUTIVO. RECURSOS A QUE SE NEGAM PROVIMENTO. ${ }^{106}$

No mesmo sentido, o TJ-SP assim decidiu:

\begin{abstract}
APELAÇÃO CIVEL N 193.953-5/6-00
Comarca de São Paulo. A apelante: Fazenda Pública do Estado de São Paulo. Apelado: Ministério Público.

Essa atividade do Poder Judiciário não configura qualquer intervenção no Executivo, muito menos no direcionamento das verbas públicas, mesmo porque encontra-se ela atrelada aos princípios constitucionais dos freios e contra-pesos e de universalização da Justiça, e em plena sincronia ao da harmonia dos Poderes do Estado. ${ }^{107}$
\end{abstract}

A jurisprudência faz uma distinção entre os direitos fundamentais e o que chama de mínimo existencial - o núcleo duro destes direitos - para se garantir a dignidade da pessoa humana. Assim, havendo o mínimo existencial, o Judiciário é obrigado não a legislar, mas a dar um passo, a implementá-la.

Com relação à efetivação do direito à educação, como o acesso a creches, escolas de educação infantil e ensino fundamental, a jurisprudência é igualmente progressista, elevando o direito à educação ao patamar de direito fundamental, e entendendo pela sua aplicabilidade imediata. Tanto que RANIERI ao realizar exame da jurisprudência recente do Supremo Tribunal Federal referente ao direito à educação, verificou expressivo aumento do número de demandas levadas ao conhecimento da Corte:

Temática relativamente marginal na jurisprudência do STF antes da Constituição Federal de 1988, no período compreendido entre 1990 e início de 2009, foram protocolados cerca de 2.250 processos, dos quais 2.215 deram entrada a partir do ano 2000.

Desde então, tem sido particularmente notável a alteração de conteúdo das decisões, em benefício da efetividade do direito à educação, em especial no que concerne à educação básica, com repercussão nas estruturas do Estado Democrático de Direito, em especial no que diz respeito ao exercício do poder político e

\footnotetext{
106 TJSP. AC 61.146-5/0-00. 2 2 Câmara de Direito Público. Rel. Lineu Peinado. 22.06.2003

107 Apelação Cível no $195.953-5 / 6-00$, de 3/02/2003. Relator: Des. Prado Pereira. $7^{\text {a }}$ Câmara de Direito Público do TJSP. Negado provimento. p. 4.
} 
à sua configuração, no plano dos valores, como verdadeiro Estado Democrático Social de Direito. ${ }^{108}$

Como exemplo, o acórdão prolatado em Agravo Regimental no Recurso Extraordinário $\mathrm{n}^{\mathrm{o}}$. 410.715-5/SP, no qual o Ministro Celso de Melo se pronunciou da seguinte forma:

Embora resida, primariamente, nos Poderes Legislativo e Executivo, a prerrogativa de formular e executar políticas públicas, revela-se possível, no entanto, ao Poder Judiciário, determinar, ainda que em bases excepcionais, especialmente nas hipóteses de políticas públicas definidas pela própria Constituição, sejam estas implementadas pelos órgãos estatais inadimplentes, cuja omissão - por importar em descumprimento dos encargos político-jurídicos que sobre eles incidem em caráter mandatório - mostra-se apta a comprometer a eficácia e integridade de direitos sociais e culturais impregnados de estatura constitucional.[...]

Esse caráter de fundamentalidade, de que se acha impregnado o direito à educação, autoriza a adoção, pelo Judiciário, de provimentos jurisdicionais que viabilizem a concreção dessa prerrogativa constitucional, mediante utilização, até mesmo, quando for o caso de medidas extraordinárias que se destinam [...] a tornar efetivo [...] o atendimento dos direitos prestacionais que congregam os valores inerentes à dignidade da pessoa humana, como é o caso do direito a educação. ${ }^{109}$

Infelizmente, quando tratamos do direito à educação para os que se encontram privados de liberdade, nem a eficácia plena, nem a aplicabilidade imediata parecem valer, sendo estes excluídos do acesso à educação de qualidade, quando não do próprio fornecimento educacional. Passaremos assim, a tratar dos direitos relativos à criança e ao adolescente, para então compreendermos a proteção especial que a legislação lhes assegura.

${ }^{108}$ RANIERI, Nina Beatriz Stocco. "O Estado Democrático de Direito e o Sentido da Exigência de Preparo da Pessoa para o Exercício da Cidadania, pela Via da Educação". Tese (Livre-Docência) Faculdade de Direito da Universidade de São Paulo. São Paulo, 2009, p. 22-23.

${ }^{109}$ SÃO PAULO, STF, RE. 410.715-5, Rel. Min. Celso de Melo, 2005. 


\section{II - A CRIANÇA E O ADOLESCENTE}

1. Direito da Criança e do Adolescente. 2. O adolescente em conflito com a lei.

\section{Direito da Criança e do Adolescente}

\section{a. Concepções que orientam o direito da criança e do adolescente}

O direito da criança e do adolescente é muito recente visto que até meados do século XIX crianças eram objetos e não titulares de direitos específicos no mundo dos adultos. E até mesmo a legislação protetiva dos direitos das crianças e adolescentes no Brasil é posterior à década de 1980. Assim, antes de estudar as concepções de infância e juventude atuais e os direitos e deveres que incidem neste grupo, cuja tutela é tão específica e necessária, realizaremos um apanhado histórico sobre a infância no Brasil.

\section{i. Escorço histórico da infância no Brasil}

No Brasil, a infância passou a ser identificada no tecido social somente em fins do século XVII e inícios do XVIII. Entretanto, é no século XX que a chamada doutrina menorista inaugura o período no qual os olhos do legislador se voltam para a criança, até então considerada objeto de direito, invisível à sociedade. Assim, com a promulgação do Código de Menores ${ }^{110}$, em 1927, as crianças passaram a ter alguns direitos e deveres legislados, como a proibição do trabalho ${ }^{111}$ para os menores de 12 anos, bem como a adoção de medidas assistencialistas e protecionistas ao "menor" abandonado ou delinquente ${ }^{112}$.

\footnotetext{
${ }^{110}$ Decreto no 17.943 -A de 12 de outubro de 1927.

${ }^{111}$ Art. 101. é prohibido em todo o territorio da Republica o trabalho nos menores de 12 annos.

Art. 102. Igualmente não se póde ocupar a maiores dessa idade que contem menos de 14 annos. e que não tenham completando sua instrucção primaria. Todavia, a autoridade competente poderá autorizar o trabalho destes, quando o considere indispensavel para a subsistencia dos mesmos ou de seus paes ou irmãos, comtanto que recebam a instrucção escolar, que lhes seja possível.

${ }^{112}$ A utilização dos termos "menor infrator" e "menor delinquente" acaba por adjetivar e estigmatizar o indivíduo em conflito com a lei, autor de infração ou crime. Assim, a criminologia crítica atual busca compreender a infração como um fenômeno transitório na vida do indivíduo, tirando o estigma do "delinquente". Como a bibliografia internacional especializada utiliza o termo "delinquência juvenil" (juvenile delinquency) esta pode vir a ser utilizada ao longo do trabalho em transcrições de textos internacionais. Porém, considero importante marcar minha posição de que a fala nunca é neutra, e por me
} 
Depois da Primeira Guerra, vários tratados internacionais estabeleceram novas regras de convivência entre os países membros da Sociedade das Nações, e um dos resultados desses tratados foi a aprovação de uma Declaração dos Direitos da Criança, na Conferência de Genebra, em 1921. No Brasil, o que se decretou foi um Código de Menores, em 1927, do qual constava a proibição do trabalho de crianças de até 12 anos e sua impunidade até os 14 anos. Dos 14 aos 18, as crianças poderiam ser internadas em "estabelecimentos especiais"e dos 18 anos em diante seriam puníveis pelos crimes cometidos. As crianças da categoria dos 14 aos 18 anos, desde então numa espécie de limbo legal, serão transformadas em menores, e os estabelecimentos especiais destinados a elas, bem como os agentes sociais que delas deveriam se encarregar, passam a ser objeto da atenção de médicos e juristas, de psicólogos e pedagogos. E, ainda que houvesse algumas divergências a respeito do modo como deveriam se distribuir o peso desse cuidado, ora com ênfase no Estado, ora na sociedade, ora na Igreja, conforme a inserção dos vários agentes envolvidos no debate, em dois pontos cruciais parece ter havido concordância entre eles: primeiro, a questão do menor abandonado era também uma questão de sua institucionalização, e, em segundo lugar, os agentes preferenciais nesse cuidado institucional seriam mulheres. ${ }^{113}$

Conforme percebemos, as crianças passam assim, a ser objeto da atenção de médicos, psicólogos e juristas que institucionalizaram a figura do menor abandonado, através de casas públicas de custódia, nas quais era aplicado o modelo compaixãorepressão dominante na doutrina da situação irregular.

O Código de Menores deu suporte à chamada "escola menorista", que via da mesma forma a criança pobre e desvalida e a criança autora de infração ou crime. Esta clara confusão conceitual, de forte influência positivista e determinista, acabou por permitir sérias violações aos direitos fundamentais tanto de crianças carentes quanto daquelas tidas como delinquentes; de modo que o, historicamente construído, binômio criança carente/delinquente, ou infância desviante, acabou por marcar o Estado, o Direito e todas as instâncias criadas para aplicação desta doutrina menorista, doutrina da situação irregular ${ }^{114}$.

O termo "menor" é, assim, repleto da carga ideológica discriminatória desta doutrina, e

alinhar às correntes de criminologia críticas, o uso de tais termos é equivocado e carregado de preconceito.

${ }^{113}$ CORRÊA, Mariza. "A cidade de menores: uma utopia dos anos 30". In: FREITAS, Marcos Cezar de (org.). História social da Infância no Brasil. 5a.ed. - São Paulo: Cortez, 2003. p. 83-84.

${ }_{114}$ MACHADO, Martha de Toledo. A proteção constitucional de crianças e adolescentes e os direitos humanos. São Paulo: Manole, 2003.p. 29. 
assim historicamente se construiu a categoria criança não escola, não família, criança desviante, criança em situação irregular, enfim, carente/delinquente, que passa a receber um mesmo tratamento - e a se distinguir de nossos filhos, que sempre foram vistos simplesmente como crianças e jovens -, compondo um nova categoria, os menores. ${ }^{115}$

Esta ideologia discriminatória que considerava a criança desvalida enquanto potencial autora de crime pode ser vista na legislação brasileira produzida sob o manto da doutrina menorista, a exemplo do Decreto Estadual Paulista $n^{\circ} 3.828$, de 25/03/25 (em seus artigos $1^{\circ}$ ao $6^{\circ}$ ), no Decreto Federal no 17.943-A (Código Mello Matos), de 12/10/27 (em seus artigos 1º 26, 27, 28, 29 e 69), além do conhecido Código de Menores 1979 que ao tratar da situação irregular preceituava que:

Art. $2^{\circ}$ Para os efeitos deste Código, considera-se em situação irregular o menor:

I - privado de condições essenciais à sua subsistência, saúde e instrução obrigatória, ainda que eventualmente, em razão de:

a) falta, ação ou omissão dos pais ou responsável;

b) manifesta impossibilidade dos pais ou responsável para provê-las;

II - vítima de maus tratos ou castigos imoderados impostos pelos pais ou responsável;

III - em perigo moral, devido a:

a) encontrar-se, de modo habitual, em ambiente contrário aos bons costumes;

b) exploração em atividade contrária aos bons costumes;

IV - privado de representação ou assistência legal, pela falta eventual dos pais ou responsável;

V - Com desvio de conduta, em virtude de grave inadaptação familiar ou comunitária;

VI - autor de infração penal.

Expressa-se aqui a Doutrina da situação irregular, na qual havia clara diferenciação entre os menores regulares, ou seja, aqueles nascidos em famílias com posses, podendo usufruir de educação, saúde e todo tipo de direito; e os irregulares, provenientes de famílias pobres, órfãos, ou que haviam cometido algum tipo de delito. 115 MACHADO, Martha de Toledo. A proteção constitucional de crianças e adolescentes e os direitos
humanos. São Paulo: Manole, 2003. p. 33 . 
Este segundo "tipo de menor" recebia tratamento jurídico diferenciado, podendo ser retirados arbitrariamente do convívio familiar, sendo levados a unidades de internação tanto órfãos ou crianças abandonadas quanto as que cometiam crimes.

A jurista e procuradora de justiça Martha de Toledo Machado afirma que tal confusão conceitual entre carência/delinquência acabou por criar um direito triplamente iníquo:

[...] porque se criou a cisão entre as crianças e os jovens em situação regular - que mereciam uma legislação própria e razoavelmente dotada das garantias iluministas, embora ainda não reconhecidos plenamente como sujeitos de direito, e aplicada por uma instância judicial revestida das garantias processuais - e aquelas em situação irregular, não merecedoras desse direito material e processual mais civilizado. [...] porque se possibilitou a implementação de medida de privação de liberdade (já que segredados nos reformatórios) de enorme massa de crianças e jovens desassistidos socialmente - que nunca foram autores de fato definido como crime -, cuja única falta teria sido o nascimento em famílias marginalizadas da fruição de riquezas coletivamente produzidas, tratando-se a problemática social como questão de polícia. ${ }^{116}$

Tal corte no ordenamento jurídico provinha de uma teoria positivista fortemente influenciada pelo determinismo lombrosiano $^{117}$, que via uma predeterminação ao crime na criança pobre, desprovida de direitos fundamentais, abandonada e/ou marginalizada. Tal ideologia justifica o tratamento totalitário àquelas crianças tidas como irregulares, punindo-as com rigor muito maior que o adulto.

Neste quadro, tudo se encaixava no vago termo "desvio de conduta", como a perambulação (caminhar pelas ruas sem destino), a ofensa a membro da família, enfim, tudo era passível de internação. Sendo o juiz a típica figura do "pai de família" que tinha poderes ilimitados para destituir a guarda de uma mãe sem sequer relatar o caso, ou deliberar sobre uma internação compulsória em casa de custódia.

Foi a doutrina da proteção integral, sedimentada pela Convenção Internacional dos Direitos da Criança da ONU de 1989, que rompeu com a doutrina

\footnotetext{
${ }^{116}$ MACHADO, Martha de Toledo. A proteção constitucional de crianças e adolescentes e os direitos humanos. São Paulo: Manole, 2003. p. 47.

117 "Lombroso parte da ideia da completa desigualdade fundamental dos homens honestos e criminosos. Preocupado em encontrar no organismo humano traços diferenciais que separassem e singularizassem o criminoso, Lombroso vai extrair da autópsia de delinquentes uma "grande série de anomalias atávicas, sobretudo uma enorme fosseta occipital média e uma hipertrofia do lóbulo cerebeloso mediano (vermis) análoga a que se encontra nos seres inferiores"." MOTA, Mauricio Jorge Pereira da. O crime segundo Lombroso. 20 de agosto de 2007. Disponível em: http://criminologiafla.files.wordpress.com/2007/08/ocrime-segundo-lombroso-texto-complementar.doc Acesso em 06.02.2012.
} 
menorista, passando os então "menores" a serem vistos como crianças e adolescentes sujeitos de direitos.

[...] Crianças e adolescentes merecem, e receberam, do ordenamento brasileiro esse tratamento mais abrangente e efetivo porque, à sua condição de seres diversos dos adultos, soma-se a maior vulnerabilidade deles em relação aos seres humanos adultos.

É esta vulnerabilidade que é a noção distintiva fundamental, sob a ótica do estabelecimento de um sistema especial de proteção, eis o que distingue crianças e adolescentes de outros grupos de seres humanos simplesmente diversos da noção do homo médio. ${ }^{118}$

Este sistema especial de proteção acaba por autorizar uma aparente quebra do princípio da igualdade, possibilitando uma diferenciação positiva feita às crianças e adolescentes vendo estes enquanto "portadores de uma desigualdade de fato" e permitindo-lhes atingir uma "igualdade jurídica material e não meramente formal"119.

A Organização das Nações Unidas - através de diversos tratados e convenções entre os quais pode-se mencionar as Regras Mínimas das Nações Unidas para a Administração da Justiça da infância e da Juventude (Regras de Beijing), as Diretrizes das Nações Unidas para a Prevenção da Delinquência Juvenil (Diretrizes de Riad), as Regras Mínimas das Nações Unidas para a Proteção de jovens Privados de Liberdade, a Convenção das Nações Unidas sobre os Direitos das Crianças - acabou por formar e fortificar a Doutrina da Proteção Integral recepcionada pela Constituição Federal do Brasil em seu art. 227, e regulada pela Lei nº 8.069/90 (Estatuto da Criança e do Adolescente).

\begin{abstract}
No plano externo, vinculando-nos às Regras Mínimas das Nações Unidas para a Administração da justiça da Infância e da juventude, Regras de Beijing (Resolução $n^{\circ}$ 40/33 da Assembleia Geral, de 29.11.85); às Diretrizes das Nações Unidas para a Prevenção da Delinquência Juvenil, Diretrizes de Riad (Assembleia Geral da ONU, novembro de 1990), enquanto que, no plano interno, a legislação brasileira é a primeira legislação latino-americana a ter incorporado em seu texto tanto as regras de proteção e garantia dos direitos do menor infrator como as de proteção da criança vítima de abandono ou outra violência, como se pode ver nos arts. 227 e 228 da Constituição Federal, no Decreto legislativo $\mathrm{n}^{\circ} 28$, de 14.9.90, e no Decreto
\end{abstract}

\footnotetext{
118 MACHADO, Martha de Toledo. A proteção constitucional de crianças e adolescentes e os direitos humanos. São Paulo: Manole, 2003. p. 119.

${ }^{119}$ MACHADO, Martha de Toledo. A proteção constitucional de crianças e adolescentes e os direitos humanos. São Paulo: Manole, 2003. p. 119.
} 
$\mathrm{n}^{\mathrm{o}}$ 99.710, de 21.11.90, que aprovaram e promulgaram a Convenção da Assembleia Geral da ONU sobre o Direito da Criança e do Adolescente, e na Lei no 8.069, de 13.7.90. ${ }^{120}$

A Constituição Federal do Brasil e o Estatuto da Criança e do Adolescente vêm, assim, romper com a antiga doutrina da situação irregular e sua nefasta tradição autoritária e excludente, que tinha na confusão conceitual entre "infância carente e infância delinquente" um instrumento jurídico extremamente poderoso à "manutenção do status quo e das desigualdades sociais"121.

\section{ii. Definição de Criança e Adolescente}

A definição de infância e juventude ${ }^{122}$ é uma construção social, sendo diferente em diversas épocas e países a idade cronológica com a qual um indivíduo deixa de ser considerado criança ou adolescente bem como os direitos e obrigações que esta divisão lhe possibilita e impõe. A concepção da infância, apesar de encontrar diferenciação histórica e geográfica, sempre esteve ligada à ideia da incapacidade e vulnerabilidade $^{123}$, e em muitas vezes, da negação de direitos, principalmente quando comparada com adultos.

Interessante a análise feita por LAJOLO sobre o termo infância e infante enquanto aquele que não fala, à que é negada ${ }^{124}$ a opinião, o dizer.

Enquanto objeto de estudo, a infância é sempre um outro em relação àquele que a nomeia e a estuda. As palavras infante, infância e demais cognatos, em sua origem latina e nas línguas daí derivadas, recobrem um campo semântico estreitamente ligado à ideia de ausência de fala. Esta noção de infância como qualidade ou estado do infante, isto é, d'aquele que não fala, constrói-se a partir dos prefixos e radicais linguísticos que compõem a palavra: in $=$ prefixo que indica negação; fante $=$ particípio presente do verbo latino fari, que significa falar, dizer.

\footnotetext{
${ }^{120}$ BULHÕES, Antônio Nabor Areias. "Depoimento na audiência pública sobre redução da maioridade penal de 18 para 16 anos, realizada em 10/11/1999". In: A razão da idade: mitos e verdades. $1^{a}$ Edição. Coleção Garantias de Direitos. Série Subsídios Tomo VII. Brasília: MJ/SEDH/DCA, 2001.p. 21.

${ }^{121}$ MACHADO, Martha de Toledo. A proteção constitucional de crianças e adolescentes e os direitos humanos. São Paulo: Manole, 2003.p. 54.

${ }^{122122} \mathrm{O}$ parâmetro adotado para conceituar juventude no Brasil é originário da Organização das Nações Unidas (ONU) estabelecido em 1985, Ano Internacional da Juventude, que circunscreve a faixa etária entre 15 e os 24 anos.

${ }^{123} \mathrm{O}$ conceito de vulnerabilidade remete à ideia de dependência e fragilidade, sendo que o índice de "vulnerabilidade juvenil" é utilizado pelo SEADE, para o direcionamento de políticas públicas/intervenções.

${ }^{124}$ Negação que esteve presente durante todo o período que vigorou a Doutrina Menorista, a ainda se encontra presente àqueles infantes pertencentes a grupos vulneráveis, pobres, periféricos, e de etnia negra.
} 
Não se estranha, portanto, que esse silêncio que se infiltra na noção de infância continue marcando-a quando ela se transforma em matéria de estudo ou de legislação. ${ }^{125}$

A noção de infância, tal como compreendida por Lajolo, acaba por marcar a doutrina, a legislação e a jurisprudência que a circunda, muitas vezes omissa em relação aos seus direitos e à proteção especial que lhes deve ser dispensada. Estas crianças eram duplamente mudas, pois além de não serem um foco de atenção especial, também não eram percebidas, ouvidas, não tinham direito à fala, nem delas se falava ${ }^{126}$.

Interessante observar na literatura - em relatos, testemunhos históricos e produção normativa - as diferentes concepções, percepções e distinções da infância; como ela aparece em função não apenas da idade, mas também do desempenho econômico. LEITE, ao buscar, ao buscar as referências feitas a crianças e adolescentes em memórias e livros de viagem do Brasil do séc. XIX, nos mostra que "uma caracterização nítida é a do período de 0 a 3 anos, em que, como ainda não andam, os pequenos são carregados pelas mães, pelos irmãos ou pelas escravas" $" 127$ sendo designados em alguns escritos, pela expressão "desvalidos de pé”.

No mesmo texto, a autora nos mostra o quanto a definição da infância é uma construção cultural e histórica, de modo que as variações e abstrações numéricas referentes à idade da maioridade eram divergentes conforme o órgão que a determinava, pois enquanto para o Código Filipino ${ }^{128}$ a maioridade "se verificava aos 12 anos para as meninas e aos 14 para os meninos"129, para a Igreja Católica esta ocorria a partir dos 7 anos.

A necessidade de classificação e afinação nos conceitos de infância leva teóricos a buscarem na psicologia a definição mais adequada e científica, como fez HOLLANDA ao definir o verbete infância:

\footnotetext{
${ }^{125}$ LAJOLO, Marisa. "Infância de papel e tinta". In: FREITAS, Marcos Cezar de (org.). História social da Infância no Brasil. $5^{\text {a }}$.ed. - São Paulo: Cortez, 2003. p. 229-230.

${ }^{126}$ MATTOSO, Katia de Queirós Mattoso apud LEITE, Miriam L. Moreira. "A infância no século XIX segundo memórias e livros de viagem”. In: FREITAS, Marcos Cezar de (org.). História social da Infância no Brasil. $5^{\text {a }}$.ed. - São Paulo: Cortez, 2003. p. 21.

${ }^{127}$ LEITE, Miriam L. Moreira. "A infância no século XIX segundo memórias e livros de viagem". In: FREITAS, Marcos Cezar de (org.). História social da Infância no Brasil. 5a.ed. - São Paulo: Cortez, 2003. p. 21.

${ }^{128}$ As Ordenações Filipinas, ou Código Filipino, é a compilação jurídica resultante da reforma do código manuelino, por Filipe II de Espanha, durante o domínio castelhano.

${ }^{129}$ LEITE, Miriam L. Moreira. "A infância no século XIX segundo memórias e livros de viagem". In: FREITAS, Marcos Cezar de (org.). História social da Infância no Brasil. 5a.ed. - São Paulo: Cortez, 2003. p. 21.
} 
Período de vida que vai do nascimento à adolescência, extremamente dinâmico e rico, no qual o crescimento se faz, concomitantemente, em todos os domínios, e que, segundo os caracteres anatômicos, fisiológicos e psíquicos, se divide em três estágios: a primeira infância, de zero a três anos; segunda infância, de três a sete anos; e terceira infância, de sete anos até a puberdade. ${ }^{130}$

Independentemente do critério utilizado, se biológico, psicológico ou biopsicológico, o fato é que a infância e a adolescência são perceptíveis e identificáveis pela simples observação do indivíduo, enquanto seus direitos e deveres mudam de acordo com a época, o lugar e a cultura que o circunda. Tanto que LAJOLO é clara ao dizer que as infâncias são tantas quantas forem as ideias, práticas e discursos em torno dela.

Mas enquanto a oscilação conceitual ensina que a vida muda, a duração do esforço conceitual ensina que a vida continua, não obstante conceitos tão diferentes sejam formulados e vigorem em nome dos mesmos primeiros tempos da cria humana, infância chamada [...]

[...] que, por isso mesmo, percebe-se, não é a mesma coisa, aqui e lá, ontem e hoje, sendo tantas infâncias quantas forem ideias, práticas e discursos que em torno dela e sobre ela se organizem. ${ }^{131}$

Em que pese a diferenciação que se faz entre crianças, adolescentes e adultos ao longo das épocas, esta classificação é necessária para critérios legislativos, de tipificação penal, e até de proteção diferenciada. Assim, nosso constituinte ao classificar crianças e adolescentes utiliza o critério biológico, considerando criança todo aquele indivíduo que nasce com vida, até os doze anos de idade incompletos, enquanto adolescente é aquele que tem doze anos completos até os dezoito anos (Art. $2^{\mathbf{o}}-$ $\left.\mathrm{ECA}^{132}\right)^{133}$.

Tal critério biológico soma-se a princípios que precedem o dito Estado Democrático de Direito, tal qual a dignidade da pessoa humana, reconhecendo, assim as

\footnotetext{
${ }^{130}$ HOLLANDA, Aurélio Buarque. Novo Dicionário. 1. ed. (5.reimpressão). Rio de janeiro, Nova Fronteira, s/d. p. 763.

${ }^{131}$ LAJOLO, Marisa. "Infância de papel e tinta". In: FREITAS, Marcos Cezar de (org.). História social da Infância no Brasil. 5a.ed. São Paulo: Cortez, 2003. p. 231.

${ }_{132}$ Art. $2^{\circ}$ Considera-se criança, para os efeitos desta Lei, a pessoa até doze anos de idade incompletos, e adolescente aquela entre doze e dezoito anos de idade.

Parágrafo único. Nos casos expressos em lei, aplica-se excepcionalmente este Estatuto às pessoas entre 18 e 21 anos de idade.

${ }^{133} \mathrm{~A} \mathrm{EC} \mathrm{n} \mathrm{o}^{\circ} 65 / 2010$ resgatou o conceito de "jovem", que diferentemente da criança e do adolescente, é aquele indivíduo entre os 18 anos completos e os 21 anos incompletos.
} 
crianças e adolescentes enquanto seres humanos que merecem proteção integral, por se encontrarem em uma fase especial de desenvolvimento. Daí o corte etário que irá priorizar políticas públicas, isentá-los de determinadas subsunções penais, e protegê-los integralmente para que se desenvolvam e se preparem para a vida adulta.

Não se pode falar na adoção, pelo Constituinte, de um critério puramente biológico. A decisão foi no sentido de valorização da dignidade humana de todas as pessoas menores de dezoito anos, de acordo com a tendência internacional de reconhecimento jurídico da doutrina da proteção integral, que acabou consubstanciada na Convenção Internacional dos Direitos da Criança. Em outras palavras, sendo o estado Democrático de Direito presidido, entre outros, pelo princípio da dignidade da pessoa humana, a fixação da imputabilidade penal aos dezoito anos representa o seu compromisso com a valorização da adolescência, por reconhecer tratar-se de uma fase especial do desenvolvimento do ser humano. ${ }^{134}$

A eleição deste critério se dá como uma forma de valorização da dignidade da pessoa humana de todos aqueles que têm idade inferior a dezoito anos, sendo este critério adotado internacionalmente, devido à utilização e ao reconhecimento da doutrina da proteção integral - que será esmiuçada posteriormente - cujo início é marcado na Convenção Internacional dos Direitos da Criança.

Importante esclarecermos que, diferentemente da nossa Carta Constitucional de 1988, a Convenção sobre os Direitos da Criança (e do Adolescente), aprovada pela Organização das Nações Unidas em 20 de novembro de 1989 e ratificada pelo Brasil em 24 de setembro de 1990, não diferencia criança e adolescente, determinando que "se trate como criança, como um ser humano com características especiais, toda pessoa com idade inferior a 18 anos" ${ }^{\prime 135}$ conforme verificamos em seu artigo 1:

\section{Artigo 1}

Nos termos da presente Convenção, criança é todo o ser humano menor de 18 anos, salvo se, nos termos da lei que lhe for aplicável, atingir a maioridade mais cedo. (grifamos)

\footnotetext{
${ }^{134}$ TERRA, Eugênio Couto. "A idade penal mínima como cláusula pétrea". In: A razão da idade: mitos e verdades. $1^{a}$ Edição. Coleção Garantias de Direitos. Série Subsídios Tomo VII. Brasília: MJ/SEDH/DCA, 2001. p. 53.

${ }^{135}$ DALLARI, Dalmo de Abreu. "A razão para manter a maioridade penal aos 18 anos”. In: A razão da idade: mitos e verdades. $1^{a}$ Edição. Coleção Garantias de Direitos. Série Subsídios Tomo VII. Brasília: MJ/SEDH/DCA, 2001. p. 26-27.
} 
Nessa Convenção reiterou-se o disposto no princípio $4^{\circ}$ da Declaração dos Direitos da Criança, de 1959, que prevê proteção e cuidados especiais à criança desde o seu nascimento.

$4^{\mathbf{0}}$ Princípio - A criança tem direito a crescer e criar-se com saúde, alimentação, habitação, recreação e assistência médica adequadas, e à mãe devem ser proporcionados cuidados e proteção especiais, incluindo cuidados médicos antes e depois do parto.

Tal proteção especial e tratamento diferenciado se fazem a partir da consideração de que crianças e adolescentes são seres vulneráveis e em formação, necessitando deste tratamento especial, deste "plus" distintivo que o legislador lhes reserva ao discutir direitos da infância e juventude.

Ao mesmo tempo em que se reiterando a afirmação de que a pessoa com menos de 18 anos tem os mesmos direitos fundamentais reconhecidos a todos os seres humanos, há também uma reiteração no reconhecimento de que a pessoa com menos de 18 anos é um ser que ainda não completou sua formação e por isso é merecedor de tratamento especial adequado. ${ }^{136}$

O legislador entendeu ser a infância e a adolescência estágios de desenvolvimento no qual deve ser garantido o "desenvolvimento de uma identidade social positiva". Assim, mais do que o fator biológico, o legislador levou em conta o fato de os conceitos de criança e adolescente serem uma criação social e histórica.

A categoria criança é de algum modo uma criação social e histórica e não apenas um fato biológico. Não é o que apenas é, parafraseando Hegel, mas o que ela se torna em sua vida, realizando-se valorativamente, a partir das contradições que a constituem inicialmente. ${ }^{137}$

Neste sentido, são interessantes os comentários de SOUSA ao analisar estudos de Emilio García Méndez (respeitado oficial de projetos do Unicef e reconhecido criminólogo), em confrontação com as análises históricas de Philippe Ariès e a percepção da infância na sociedade.

\footnotetext{
${ }^{136}$ DALLARI, Dalmo de Abreu. “A razão para manter a maioridade penal aos 18 anos”. In: A razão da idade: mitos e verdades. $1^{\mathrm{a}}$ Edição. Coleção Garantias de Direitos. Série Subsídios Tomo VII. Brasília: MJ/SEDH/DCA, 2001. p. 26-27.

${ }^{137}$ SOUSA Jr., José Geraldo de. "A construção social e teórica da criança no imaginário jurídico”. In: A razão da idade: mitos e verdades. $1^{a}$ Edição. Coleção Garantias de Direitos. Série Subsídios Tomo VII. Brasília: MJ/SEDH/DCA, 2001. p. 107-108.
} 
Para ele que confronta seus estudos analíticos com percepções que incluem análises históricas como as de Philippe Ariès, a partir do exame de pinturas (retratos de famílias que captam o universo de sistemas sociais e os lugares dos indivíduos nesses sistemas, uma tese plenamente reconhecida é a de que na sociedade tradicional, e até já bem entrado o século XVI, a infância tal como ela é entendida hoje, não existia: refutando las tesis de la psicología positivista que vinculan la categoría niñez a determinadas características de la evolución biológica, El enfoque histórico la presenta como El resultado de una compleja construcción social que responde, tanto a condicionamientos de carácter estructural cuanto a sucesivas revoluciones en El plano de los sentimientos. ${ }^{138}$ (grifamos)

Concluímos assim que existem diferentes critérios a serem utilizados para a determinação dos marcos que dividem infância, adolescência e vida adulta (biológico, psicológico ou misto); diferentes valores e princípios a serem considerados (vulnerabilidade, fase de desenvolvimento, proteção, etc.); além das diferentes percepções que o homem tem da infância e da juventude; são determinadas socialmente (pela época, lugar, cultura) e influenciarão o legislador ao estabelecer os marcos etários que protegem ou criminalizam.

\section{b. Sistema Constitucional especial de proteção aos direitos fundamentais da criança e do adolescente}

O Sistema Constitucional especial de proteção aos direitos fundamentais da criança e do adolescente instituído pela Constituição Federal de 1988 é expressamente referido no parágrafo $3^{\circ}$ do artigo $227^{139}$. Ao justificar o estabelecimento do Sistema Especial de Proteção, MACHADO enfatiza a distinção das crianças e adolescentes dos outros grupos e o tratamento mais abrangente que lhes é dado (autorizado e operado pelo ordenamento), os quais buscam atingir a igualdade jurídica material equilibrando a desigualdade de fato.

Sob a ótica desta função organizadora e reguladora estática das relações sociais que o ordenamento cumpre, é esta vulnerabilidade peculiar que é a noção distintiva fundamental e

\footnotetext{
138 SOUSA Jr., José Geraldo de. "A construção social e teórica da criança no imaginário jurídico”. In: $A$ razão da idade: mitos e verdades. $1^{\mathrm{a}}$ Edição. Coleção Garantias de Direitos. Série Subsídios Tomo VII. Brasília: MJ/SEDH/DCA, 2001. p. 107-108.

${ }^{139}$ Art. 227. É dever da família, da sociedade e do Estado assegurar à criança, ao adolescente e ao jovem, com absoluta prioridade, o direito à vida, à saúde, à alimentação, à educação, ao lazer, à profissionalização, à cultura, à dignidade, ao respeito, à liberdade e à convivência familiar e comunitária, além de colocá-los a salvo de toda forma de negligência, discriminação, exploração, violência, crueldade e opressão.
} 
fundante para o estabelecimento de um sistema especial de proteção, porque: a) distingue crianças e adolescentes de outros grupos de seres humanos simplesmente diversos da noção do homo médio; b) autoriza e opera a aparente quebra do princípio da igualdade - porque são portadores de uma desigualdade inerente, intrínseca, o ordenamento confere-lhes tratamento mais abrangente como forma de equilibrar a desigualdade de fato e atingir a igualdade jurídica material e não meramente formal -, mediante 'processo de especialização do genérico, no qual se realiza o respeito à máxima suum cuique tribuere', como referiu Bobbio $^{140}$.

O sistema constitucional especial de proteção deriva do disposto nos artigos 226, 227, 228 e 229 da Constituição Federal, sendo a prioridade absoluta, a tutela diferenciada (em razão da vulnerabilidade externa do sujeito) e a igualdade entre crianças e adolescentes, princípios constitucionalmente previstos. $\mathrm{O}$ texto Constitucional ao tratar do dever da família, da comunidade, da sociedade e do poder público em assegurar este sistema especial de proteção aos direitos fundamentais da criança e do adolescente, é claro e redundante, por entender que se trata de seres humanos em processo de desenvolvimento.

Desnecessário dizer que a responsabilização especial foi insculpida na legislação pátria, através de novo ramo do direito brasileiro, que é o Direito da Criança e do Adolescente, criado pela Lei 8.069/90, que tem como fontes formais a Doutrina da proteção Integral, Consubstanciada no Direito Internacional Convenção das Nações Unidas, Regras de Riad, Regras de Beijing, e, no Direito Pátrio, como fonte a própria Constituição Federal em seus artigos $227,228,204$, II e $\$ 2^{\circ}$ do art. $5^{\text {ol41 }}$.

Crianças e adolescentes se diferenciam dos adultos por se constituírem como seres em desenvolvimento e não simplesmente por sua maior vulnerabilidade na fruição, reivindicação e defesa de direitos.

Sob esse enfoque estrito, mas não menos relevante, as razões fundantes da diferenciação não estão ligadas ao aspecto de "fraqueza" dos sujeitos do direito; mas sim à força potencial que a infância e a juventude representam para a nação, força que, num primeiro momento, poderia vir reduzida àquele truísmo do senso comum: a infância é o futuro da nação. ${ }^{142}$

\footnotetext{
${ }^{140}$ MACHADO, Martha de Toledo. A proteção constitucional de crianças e adolescentes e os direitos humanos. São Paulo: Manole, 2003.

${ }^{141}$ NETO, Gercino Gerson Gomes. "A inimputabilidade penal como cláusula pétrea". In: A razão da idade: mitos e verdades. $1^{\mathrm{a}}$ Edição. Coleção Garantias de Direitos. Série Subsídios Tomo VII. Brasília: MJ/SEDH/DCA, 2001. p. 88-89.

${ }^{142}$ MACHADO, Martha de Toledo. A proteção constitucional de crianças e adolescentes e os direitos humanos. São Paulo: Manole, 2003. p. 132.
} 
A Fundação Sistema Estadual de Análises de Dados (SEADE) utiliza o termo "vulnerabilidade juvenil" em vez de "adolescentes em situação de risco" ou “adolescentes em situação de exclusão social” por entender que a problemática na qual os adolescentes estão envolvidos é grave e complexa, não se limitando aos adolescentes pobres e desassistidos. Neste sentido, ela se utiliza de um índice de vulnerabilidade juvenil (IVJ) para "auxiliar na escolha de áreas de intervenção"143 e desenvolvimento de políticas públicas especificas aos jovens.

A rede para a manutenção e promoção do sistema especial de proteção aos direitos fundamentais das crianças é imensa, sendo a Política Nacional dos Direitos Humanos de Crianças e Adolescentes e o Plano Decenal dos Direitos Humanos de Crianças e Adolescentes construídos conjuntamente pelo Conselho Nacional dos Direitos da Criança e do Adolescente (Conanda), e a Secretaria de Direitos Humanos (SDH), da Presidência da República.

O Conanda - Conselho Nacional dos Direitos da Criança e do Adolescente -, por meio de suas resoluções e diretrizes para o final do século passado e início do século XXI, norteou suas políticas públicas em construir propostas estratégicas, descentralizadas para o Brasil, não só para educação, saúde, lazer, cultura, profissionalização etc. além de planos nacionais de erradicação do trabalho infantil e combate radical à exploração sexual infanto-juvenil, bem como a implantação do Sipia - Sistema de Informações para a Infância e a Adolescência - em todo o território nacional. ${ }^{144}$

Concluímos que, a Constituição Federal, ao priorizar a efetivação dos direitos fundamentais das crianças e adolescentes, fez mais do fixar os direitos individuais e sociais, pois para serem efetivados o Estado deve se organizar no facere e praestare, e os órgãos públicos, privados e entidades da sociedade civil devem ter uma postura ativa e comprometida socialmente.

\section{c. Doutrina do respeito à peculiar condição de pessoa em desenvolvimento}

\footnotetext{
${ }^{143}$ http://www.seade.gov.br/produtos/ivj - Acesso em 04.02.2012.

${ }^{144}$ GRACIANI, Maria Stela Santos. "Os desafios da implantação das medidas socioeducativas no Brasil". In: A razão da idade: mitos e verdades. $1^{\mathrm{a}}$ Edição. Coleção Garantias de Direitos. Série Subsídios Tomo VII. Brasília: MJ/SEDH/DCA, 2001. p. 160.
} 
A peculiar condição de pessoa em desenvolvimento é tida como central no sistema especial de proteção dos direitos fundamentais de crianças e adolescentes que permeia toda a legislação constitucional brasileira.

Esse sistema especial de proteção vem expressamente referido no parágrafo $3^{\circ}$ do artigo 227 - embora não se reduza às garantias ali posicionadas. De fato, ele permeia todo o artigo 227 e o artigo 228, e manifesta-se, ainda que subsidiariamente, também no disposto nos artigos 226 , caput e $\S \S 3^{\circ}, 4^{\circ}, 5^{\circ}$ e $8^{\circ}$ e 229, primeira parte, todos da Constituição Federal. Mas diz, também diretamente, com outros dispositivos da Constituição, como os incisos XXXIII e XXX do artigo $7^{\circ}$ e o $\$ 3^{\circ}$ do artigo $208 .^{145}$

O chamado princípio do respeito à peculiar condição de pessoa em desenvolvimento tem como pressuposto o reconhecimento de que a personalidade infanto-juvenil é distinta da adulta, necessitando diferenciação de tratamento ${ }^{146}$. Para MACHADO, a peculiar condição das crianças e adolescentes de seres humanos em processo de desenvolvimento é o núcleo duro, "noção fundamental e fundante" ${ }^{147}$ do sistema especial de proteção aos direitos de crianças e adolescentes, independente de tratarmos a partir do interesse individual ou do social.

Por se encontrar em processo formação (física, psíquica, moral, etc.) - na peculiar condição de pessoas humanas em desenvolvimento - a criança e o adolescente demandam proteção jurídica especial, o reconhecimento de direitos especiais, permitindo-lhes construir suas potencialidades e desenvolver sua personalidade para a vida adulta.

Crianças e adolescentes são pessoas que ainda não desenvolveram completamente sua personalidade.

Essa característica é inerente à sua condição de seres humanos ainda em processo de formação, sob todos os aspectos, v.g., físico (nas suas facetas constitutiva, motora, endócrina, da própria saúde, como situação dinâmica), psíquico, intelectual (cognitivo), moral, social etc. ${ }^{148}$

\footnotetext{
145 MACHADO, Martha de Toledo. A proteção constitucional de crianças e adolescentes e os direitos humanos. São Paulo: Manole, 2003. p. 105.

${ }^{146}$ MACHADO, Martha de Toledo. "Direito da Infância e Juventude". In: NUNES Jr., Vidal Serrano (Coord). Manual de Direitos Difusos. São Paulo: Editora Verbatim, 2009. p. 152.

${ }^{147}$ MACHADO, Martha de Toledo. A proteção constitucional de crianças e adolescentes e os direitos humanos. São Paulo: Manole, 2003. p. 135.

${ }^{148}$ MACHADO, Martha de Toledo. A proteção constitucional de crianças e adolescentes e os direitos humanos. São Paulo: Manole, 2003.p. 109.
} 
Como seres humanos em situação fática peculiar de desenvolvimento, os direitos fundamentais de crianças e adolescentes são compreendidos de maneira especial, sendo necessários, essenciais, especiais e de estruturação diversa. Esse direito peculiar de se formar, de se desenvolver está diretamente ligado a personalidade, conforme ensinamento de CUPIS.

Todos os direitos, na medida em que destinados a dar conteúdo à personalidade, poderiam chamar-se 'direitos da personalidade'. No entanto, na linguagem jurídica corrente esta designação é reservada àqueles direitos subjectivos cuja função, relativamente à personalidade, é especial, constituindo o 'mininum' necessário e imprescindível a seu conteúdo. Por outras palavras, existem certos direitos sem os quais a personalidade restaria uma susceptibilidade completamente irrealizada, privada de todo o valor concreto: direitos sem os quais todos os outros direitos subjetivos perderiam todo o interesse para o indivíduo - o que equivale a dizer que, se eles não existirem, a pessoa não existiria como tal. São esses os chamados 'direitos essenciais', com os quais se identificam precisamente os direitos da personalidade. Que a denominação da personalidade seja reservada aos direitos essenciais justificase plenamente pela razão de que eles constituem a medula da personalidade. ${ }^{149}$

Tendo como princípio o respeito à peculiar condição de pessoa em desenvolvimento, o Estado, a sociedade e a família devem buscar desenvolver as potencialidades das crianças e adolescentes, estimulando seu exercício de direitos e visando seu desenvolvimento integral.

\section{d. Doutrina da prioridade absoluta}

O princípio da prioridade absoluta é assim chamado por obrigar, conforme dispõe o artigo 227 da Constituição Federal, que Estado, sociedade e família assegurem “o direito à vida, à saúde, à alimentação, à educação, ao lazer, à profissionalização, à cultura, à dignidade, ao respeito, à liberdade e à convivência familiar e comunitária" das crianças e adolescentes, com prioridade absoluta; estando estes interesses infantojuvenis num plano superior ao dos adultos.

Quis o constituinte separar os direitos e garantias das crianças e adolescentes das disposições relativas ao conjunto da cidadania, visando sua maior implementação e defesa. Elegeu tais direitos, colocando-os em artigo próprio, com um princípio intitulado de prioridade absoluta, que faz com que a criança tenha prioridade

\footnotetext{
${ }^{149}$ CUPIS, Adriano de. Os direitos da personalidade, Lisboa, Morais, 1961, p. 17-18.
} 
na implementação de políticas públicas, por exemplo, e desta forma, inclusive por questão de coerência jurídicoconstitucional, não iria deixar ao desabrigo do artigo $60, \S 4^{\circ}$, IV, os direitos e garantias individuais de crianças e adolescentes, quando, foi justamente o contrário que desejou e o fez. ${ }^{150}$

O princípio da prioridade absoluta obriga, assim, que a família, o Estado e a sociedade garantam à criança e ao adolescente um desenvolvimento pleno e sadio nos termos do artigo 227.

\begin{abstract}
Art. 227. É dever da família, da sociedade e do Estado assegurar à criança, ao adolescente e ao jovem, com absoluta prioridade, o direito à vida, à saúde, à alimentação, à educação, ao lazer, à profissionalização, à cultura, à dignidade, ao respeito, à liberdade e à convivência familiar e comunitária, além de colocá-los a salvo de toda forma de negligência, discriminação, exploração, violência, crueldade e opressão. (grifamos)
\end{abstract}

Vemos que a expressão "absoluta prioridade" tem no plano Constitucional o sentido de 'prioridade primeira' buscando salvaguardar crianças e adolescentes - seres em desenvolvimento e em situação especial de maior vulnerabilidade - e permitir-lhes desenvolver plenamente suas potencialidades. Colocando "interesses de crianças e adolescentes num plano superior aos interesses dos adultos"; "como meio de equilibrar a desigualdade fática" ${ }^{" 151}$ que experimentam por sua peculiar condição.

\title{
e. Doutrina da proteção integral
}

A Constituição Federal de 1988 inseriu o paradigma de proteção integral dos direitos fundamentais das crianças e dos adolescentes por considerar haver tanto a necessidade de uma autonomia progressiva do ser humano em desenvolvimento, quanto de uma proteção integral.

Conforme vimos no rápido escorço histórico feito, crianças e adolescentes eram tidos pelo ordenamento jurídico como objetos de direito, sujeitos às intervenções do mundo adulto. Somente com a Constituição de 1988 e o Estatuto da Criança e do Adolescente de 1990, e a concepção doutrinária da Proteção Integral neles incorporada, é que passaram à condição de sujeitos de direitos.

\footnotetext{
${ }^{150}$ NETO, Gercino Gerson Gomes. “A inimputabilidade penal como cláusula pétrea”. In: A razão da idade: mitos e verdades. $1^{\mathrm{a}}$ Edição. Coleção Garantias de Direitos. Série Subsídios Tomo VII. Brasília: MJ/SEDH/DCA, 2001. p. 83.

${ }^{151}$ MACHADO, Martha de Toledo. A proteção constitucional de crianças e adolescentes e os direitos humanos. São Paulo: Manole, 2003. p. 392.
} 
A criança e o adolescente passam, assim, a ter mais direitos fundamentais que os adultos, já que por se encontrarem neste período especial necessitam de um "plus" de direitos, tal qual o direito ao não trabalho até os 14 anos, o direito ao trabalho protegido dos 14 aos 16 anos, o direito de brincar, o direito a imputabilidade penal, à excepcionalidade e brevidade da privação de liberdade.

[...] Sem a menor dúvida, pode-se afirmar que a proteção normativa outorgada à infância e juventude é uma explicitação do princípio da dignidade humana. Mas o Constituinte acrescentou um plus, tornou a consecução plena de tal princípio prioritária em relação à criança e ao adolescente, E esse acréscimo - mesmo tendo ocorrido fora das disposições do Título I - erige a total preferência estabelecida como um princípio fundamental, integrativo do núcleo essencial da Constituição. ${ }^{152}$

O artigo 227 da Constituição Federal veicula, assim, a síntese da doutrina da proteção integral; proteção que também é vista na Convenção Internacional dos Direitos da Criança, aprovada pela Assembleia Geral da Organização das Nações Unidas, em 20.11.1989, tal qual vemos em seu artigo 3.

\section{Artigo 3}

1. Todas as decisões relativas a crianças, adoptadas por instituições públicas ou privadas de protecção social, por tribunais, autoridades administrativas ou órgãos legislativos, terão primacialmente em conta o interesse superior da criança.

2. Os Estados Partes comprometem-se a garantir à criança a protecção e os cuidados necessários ao seu bem-estar, tendo em conta os direitos e deveres dos pais, representantes legais ou outras pessoas que a tenham legalmente a seu cargo e, para este efeito, tomam todas as medidas legislativas e administrativas adequadas.

No Brasil, por se integrar no rol de direitos e garantias fundamentais, o tratamento jurídico diferenciado não pode ser objeto de deliberação proposta de emenda constitucional tendente a aboli-los, pois tal atitude vai contra o artigo $60, \S 4^{\circ}$, da Constituição que trata das cláusulas pétreas ${ }^{153}$.

\footnotetext{
${ }^{152}$ TERRA, Eugênio Couto. "A idade penal mínima como cláusula pétrea". In: A razão da idade: mitos e verdades. $1^{a}$ Edição. Coleção Garantias de Direitos. Série Subsídios Tomo VII. Brasília: MJ/SEDH/DCA, 2001. p. 39.

${ }^{153}$ DALLARI, Dalmo de Abreu. "A razão para manter a maioridade penal aos 18 anos”. In: A razão da idade: mitos e verdades. $1^{a}$ Edição. Coleção Garantias de Direitos. Série Subsídios Tomo VII. Brasília: MJ/SEDH/DCA, 2001. p. 25.
} 
Vemos assim, a importância que a Constituição brasileira de 1988 dá aos direitos fundamentais de crianças e adolescentes, concepção de direitos humanos, que nas palavras de MACHADO é unitária.

[...] em relação aos direitos fundamentais de crianças e adolescentes a Constituição brasileira de 1988 abraçou explícita e cristalinamente a concepção unitária dos direitos humanos, digamos assim, reconhecendo a inafastável interdependência entre os chamados 'direitos civis', ou 'direitos da liberdade' e os chamados 'direitos sociais', ou 'direitos da igualdade': na essência da problemática, apenas se alcança efetividade plena para qualquer destas 'classes' de direitos quando todos estão suficientemente satisfeitos.

Penso, outrossim, que aqui reside o centro da ideia de proteção integral aos direitos fundamentais de crianças e adolescentes. Esse núcleo é a noção de que sem a efetivação dos chamados 'direitos sociais' de crianças e adolescentes - especialmente educação, saúde, profissionalização, direito ao não trabalho no seu particular imbricamento com o direito à alimentação - não se logrará material proteção a seus direitos fundamentais. ${ }^{154}$

Partindo desta concepção 'unitária' de direitos humanos, na qual a proteção aos direitos fundamentais de crianças e adolescentes depende da garantia de toda uma rede de proteção e de direitos individuais e sociais, buscaremos analisá-los, em especial o direito à educação.

\section{f. Direitos fundamentais especiais de criança e adolescente}

A conformação estrutural especial dos direitos fundamentais de crianças e adolescentes busca superar a dicotomia entre os direitos constitucionalmente elencados e sua efetivação, afinal, conforme já exposto, o tratamento de seres considerados diferentes, deve ser necessariamente diferente.

O nosso Estado Democrático Social de Direito destina-se a assegurar o exercício de direitos fundamentais - sociais e individuais -, principalmente no que se refere aos da criança e adolescente (devido sua peculiar condição de pessoa em desenvolvimento).

[...] norteou-se a Constituição pela força potencial que a efetivação dos direitos fundamentais de crianças e adolescentes tem na obtenção do patamar mínimo de igualdade, necessário à dignidade humana, para - no arco entre os polos de prestação eminentemente negativa e prestação eminentemente positiva

\footnotetext{
${ }^{154}$ MACHADO, Martha de Toledo. A proteção constitucional de crianças e adolescentes e os direitos humanos. São Paulo: Manole, 2003. p. 136.
} 
que a positivação de qualquer direito fundamental teoricamente comporta - situar todos os direitos fundamentais de crianças e adolescentes nesse segundo extremo, como forma de assegurar maior efetividade a seus direitos fundamentais. ${ }^{155}$

A Constituição, assim, não distingue os direitos fundamentais da criança e adolescente em classes, estando todos nos rol de direitos do artigo 227, devendo o Estado adotar uma postura ativa (prestacional e não de abstenção) em relação a esses direitos. Tais direitos fundamentais são especiais, e se diferenciam do direito dos adultos conforme tratado no capítulo I.

Dentre os direitos fundamentais especiais de crianças e adolescentes podemos citar o direito à convivência familiar, ao não trabalho, à profissionalização, entre outros. $\mathrm{O}$ escopo da presente pesquisa se atém ao direito fundamental à educação na privação de liberdade. Neste sentido, nos deteremos em esmiuçar os direitos à educação e à liberdade.

O primeiro já fora tratado em capítulo próprio, cabendo-nos realizar breves comentários sobre o tão precioso direito à liberdade. Este também encontra tutela especial dentro do sistema de proteção aos direitos fundamentais da criança e adolescente, pois em que pese a imaturidade e vulnerabilidade deste grupo, o seu direito à liberdade é inafastável, possuindo especificidades em razão da idade.

É que a liberdade da pessoa física em fase de desenvolvimento tem suas especificidades ${ }^{156}$, ligadas à questão da imaturidade de crianças e adolescentes, que impede que estas se protejam de agressões do meio social e limita, juridicamente, o próprio reconhecimento da validade da vontade de crianças $\mathrm{e}$ adolescentes, ínsito no exercício da liberdade da pessoa física, exatamente em razão da imaturidade e da vulnerabilidade que aquela traz em si. ${ }^{157}$

Nas lições de SILVA:

A questão da liberdade da criança e do adolescente envolve uma problemática muito complexa, dadas sua posição jurídica no seio da família e da escola e a sua condição peculiar de pessoa em desenvolvimento. Lembra Neill que a'liberdade é necessária

\footnotetext{
${ }^{155}$ MACHADO, Martha de Toledo. A proteção constitucional de crianças e adolescentes e os direitos humanos. São Paulo: Manole, 2003. p. 385.

${ }^{156}$ CURY, Munir (Org). Estatuto da Criança e do Adolescente comentado. Malheiros Editores, 2008. p. 63-71.

${ }^{157}$ MACHADO, Martha de Toledo. A proteção constitucional de crianças e adolescentes e os direitos humanos. São Paulo: Manole, 2003. p. 208.
} 
para a criança porque apenas sob liberdade ela pode crescer de sua maneira natural - a boa maneira. ${ }^{158}$

O direito à liberdade da criança e do adolescente é especificado artigo 16 do Estatuto da Criança e do Adolescente, nos seguintes termos:

Art. 16. Direito à liberdade compreende os seguintes aspectos:

I - ir, vir e estar nos logradouros públicos e espaços comunitários, ressalvadas as restrições legais;

II - opinião e de expressão;

III - crença e culto religioso;

IV - brincar praticar esportes e divertir-se;

V - participar da vida familiar e comunitária, sem discriminações;

VI - participar da vida política na forma da lei;

Entretanto, o direito à liberdade é passível de restrição em detrimento da busca pela proteção integral, prioridade absoluta, e do respeito à peculiar condição de desenvolvimento, isto é, ele pode ser limitado quando se busca garantir a proteção e o desenvolvimento integral da criança e do adolescente, longe de violações a outros direitos, violência e privações. Exemplo de limitação são as chamadas medidas de proteção, adotadas em razão da situação de risco (artigo $98^{159}$ do ECA), que buscam a preservação/recomposição dos direitos fundamentais das crianças e adolescentes, tanto que o artigo $101^{160}$, em seu parágrafo único, é claro ao dispor que o abrigo não pode consubstanciar privação de liberdade, cárcere, prisão.

\footnotetext{
${ }^{158}$ SILVA, José Afonso. Curso de direito constitucional positivo. 9a edição. São Paulo: Malheiros, 1992, p. 71

${ }_{159}$ Art. 98. As medidas de proteção à criança e ao adolescente são aplicáveis sempre que os direitos reconhecidos nesta Lei forem ameaçados ou violados:

I - por ação ou omissão da sociedade ou do Estado;

II - por falta, omissão ou abuso dos pais ou responsável;

III - em razão de sua conduta.

${ }^{160}$ Art. 101. Verificada qualquer das hipóteses previstas no art. 98, a autoridade competente poderá determinar, dentre outras, as seguintes medidas:

I - encaminhamento aos pais ou responsável, mediante termo de responsabilidade;

II - orientação, apoio e acompanhamento temporários;

III - matrícula e frequência obrigatórias em estabelecimento oficial de ensino fundamental;

IV - inclusão em programa comunitário ou oficial de auxílio à família, à criança e ao adolescente;

$\mathrm{V}$ - requisição de tratamento médico, psicológico ou psiquiátrico, em regime hospitalar ou ambulatorial;

VI - inclusão em programa oficial ou comunitário de auxílio, orientação e tratamento a alcoólatras e toxicômanos;

VII - abrigo em entidade;

VIII - colocação em família substituta.
} 
Quando falamos de liberdade dentro do Direito positivo, tratamos da sua espécie objetiva; por sua se utilizarmos o termo liberdades este melhor representa as diversas formas, expressões externas da liberdade, divididas por SILVA em cinco grandes grupos:

(1) liberdade da pessoa física (liberdade de locomoção, de circulação);

(2) liberdade de pensamento, com todas as suas liberdades (opinião, religião, informação, artística, comunicação do conhecimento);

(3) liberdade de expressão coletiva em suas várias formas (de reunião, de associação);

(4) liberdade de ação profissional (livre escolha e de exercício de trabalho, ofício e profissão);

(5) liberdade de conteúdo econômico e social (liberdade econômica, livre iniciativa, liberdade de comércio, liberdade ou autonomia contratual, liberdade de ensino e liberdade de trabalho), de que trataremos entre os direitos econômicos $e$ sociais, porque não integram o campo dos direitos individuais, mas o daqueles. ${ }^{161}$

Com relação ao adolescente em conflito com a lei, a liberdade da qual ele é privado é a liberdade individual, da pessoa física. Afinal, quando um adolescente realiza conduta criminalizada socialmente, ele será sancionado pelo aparelho estatal, podendo ter a sua liberdade subtraída para aplicação de medida de semiliberdade ou de privação de liberdade, as quais devem ser excepcionais e breves. Trataremos, assim, das crianças e adolescentes em conflito com a lei e das sanções a eles aplicadas, principalmente as restritivas de liberdade.

\section{A criança e o adolescente em conflito com a lei}

O debate sobre a redução da maioridade penal e o sistema de justiça juvenil, muitas vezes é inflamada por ardorosos defensores do direito penal máximo, do direito penal do inimigo ${ }^{162}$, da putabilidade de crianças e adolescentes ${ }^{163}$ e da possibilidade de

Parágrafo único. O abrigo é medida provisória e excepcional, utilizável como forma de transição para a colocação em família substituta, não implicando privação de liberdade.

${ }^{161}$ SILVA, José Afonso da. Curso de direito constitucional positivo. $30^{a}$ edição, revista e atualizada. São Paulo: Malheiros, 2008. p. 235.

162 "Em lugar de uma pessoa competente, que é contraditada com a pena, portanto, coloca-se o indivíduo perigoso [3], contra quem - aqui: com uma medida preventiva, não com uma pena - é procedido de modo fisicamente efetivo: combate ao perigo, em lugar de comunicação, Direito penal do inimigo (...), em vez de Direito Penal do cidadão...”. JAKOBS, Bürgerstrafrecht und Feindstrafrecht, 2004, Caderno 3, p. 89 s. 
prisão junto a adultos para aqueles acusados de cometer infrações e/ou crimes. Tal discurso misturado ao senso comum e às reduções da fala do crime ${ }^{164}$ acaba por afirmar posturas discriminatórias através de um discurso ambíguo que distorce o disposto no Sistema Constitucional especial de proteção aos direitos fundamentais da criança e do adolescente, confundindo imputabilidade penal com impunidade.

Proteção e imputabilidade não é impunidade, de modo que o adolescente que comete ato considerado crime responde por ele, sendo previstas, no Estatuto da Criança e do Adolescente, diversas medidas socioeducativas, havendo até a previsão de internação em estabelecimentos prisionais.

Tanto que MACHADO é clara ao afirmar a continuidade das limitações gerais impostas ao Estado quando sua atuação concerne a preservação da paz social:

Para que se atinja efetiva proteção aos direitos fundamentais desses sujeitos especiais, o que cumpre, e a Constituição o fez, é ampliar tal sistema de garantias, dadas as peculiaridades do sujeito dos direitos e garantias; mas não abandonar, ou abrandar, as limitações gerais impostas ao Estado quando exerce a função de preservação da paz social. ${ }^{165}$

O artigo $228^{166}$ dispõe, em sua segunda parte, que em que pese o adolescente ser inimputável penalmente, este responde na forma disposta em legislação especial, havendo assim a garantia social de responsabilização do adolescente, a qual ocorrerá na forma de uma legislação especial, em virtude de seu direito individual ${ }^{167}$. Afinal, o fato tipificado, punível e culpável ${ }^{168}$ é sancionado pelo Estado dentro dos limites estabelecidos pela legislação protetiva da criança e do adolescente, comportando, tal qual as sanções previstas aos adultos, a privação da liberdade.

\footnotetext{
163 Utilizaremos os termos adolescência e juventude enquanto sinônimos, acreditando na ideia de sobreposição etária de tais conceitos e procurando rechaçar a tendência de reservar o termo adolescente para os autores de atos infracionais e o termo juventude para aqueles que não cometeram atos infracionais, em um claro resgate a dicotomia criança/menor paradigma da Doutrina da Situação Irregular. Tendência apontada por SILVA em seu livro Pedagogia Social (Roberto da Silva, João C. de Souza Neto, Rogério A. de Moura (org.). São Paulo: Expressão e Arte Editora, v.1. 2 $2^{\mathrm{a}}$ edição, 2011.).

${ }^{164}$ A pesquisadora Teresa Pires do Rio Caldeira, em seu livro "Cidade de muros" nos mostra o quanto a "fala do crime" lida com categorias simplistas, imagens essencializadas e repetição de estereótipos, de modo a elaborar preconceitos.

${ }^{165}$ MACHADO, Martha de Toledo. A proteção constitucional de crianças e adolescentes e os direitos humanos. São Paulo: Manole, 2003. p. 238.

166 Art. 228. “[...] são penalmente inimputáveis os menores de dezoito anos, sujeitos às normas da legislação especial".

${ }^{167}$ NETO, Gercino Gerson Gomes. "A inimputabilidade penal como cláusula pétrea". In: A razão da idade: mitos e verdades. $1^{\mathrm{a}}$ Edição. Coleção Garantias de Direitos. Série Subsídios Tomo VII. Brasília: MJ/SEDH/DCA, 2001. p. 86.

${ }^{168}$ Conceito de crime dentro da teoria tripartida,
} 
O fato que está na base da intervenção do Estado quando segrega o adolescente é o mesmo que leva à segregação do adulto: O CRIME.

Mais. É em face da prática do crime que se aplica uma sanção, mesmo que essa sanção, quando se trata do inimputável em razão da idade, seja diversa da pena criminal. ${ }^{169}$

No direito penal juvenil, a conduta análoga a crime ou contravenção penal praticada por adolescente é chamada ato infracional. Esta permite que o adolescente infrator seja sujeito de medida socioeducativa prevista nos artigos 103, 104 e 212 do Estatuto da Criança e do Adolescente.

Em primeiro lugar é preciso saber que há um sistema de responsabilização destinado ao adolescente em conflito com a lei. O ECA prevê ao jovem seis tipos de sanções, que vão da advertência à aplicação de medidas socioeducativas, no caso, a obrigação de reparar o dano, a prestação de serviços à comunidade, a liberdade assistida, a semiliberdade e a internação, sendo que nessa última a privação de liberdade pode chegar a três anos e no fim desse período ainda é possível encaminhar o mesmo adolescente a um regime de semiliberdade ou liberdade assistida, onde pode ficar até completar 21 anos de idade. ${ }^{170}$

Se a conduta é tida como imoral ou contra os bons costumes, mas esta pessoa em desenvolvimento é menor de 12 anos; a conduta passa a ser classificada como desvio, sendo a criança sujeita a medida específica de proteção. Abaixo podemos analisar esquematicamente as principais diferenças entre ato infracional e desvio de conduta, lembrando que quando vigorava a doutrina menorista, ao vago termo desvio de conduta se lhe imputava todo e qualquer comportamento fora das regras estabelecidas, além de caber-lhe pena.

\footnotetext{
${ }^{169}$ MACHADO, Martha de Toledo. A proteção constitucional de crianças e adolescentes e os direitos humanos. São Paulo: Manole, 2003. p. 235.

${ }^{170}$ COSTA, José Haroldo Teixeira da. "Reduzir a idade penal não é a solução". In: A razão da idade: mitos e verdades. $1^{a}$ Edição. Coleção Garantias de Direitos. Série Subsídios Tomo VII. Brasília: MJ/ SEDH/DCA, 2001. p. 114.
} 


\begin{tabular}{|l|l|}
\hline \multicolumn{1}{|c|}{ Ato infracional ${ }^{171}$} & \multicolumn{1}{|c|}{ Desvio de Conduta } \\
\hline $\begin{array}{l}\text { Adolescente que comete conduta prevista } \\
\text { como crime ou contravenção }\end{array}$ & $\begin{array}{l}\text { Criança que pratica conduta prevista como } \\
\text { crime e contravenção, ou, ainda, conduta } \\
\text { atentatória à sua formação. } \\
\text { Este último tipo de conduta não é tida, porém, } \\
\text { como crime ou contravenção pela legislação. }\end{array}$ \\
\hline $\begin{array}{l}\text { Medida socioeducativa - portanto (entre eles, } \\
\text { até medidas específicas de proteção, desde que } \\
\text { as previstas no art.101, incisos I a IV, ou seja, } \\
\text { não se aplicam as MEPs de acolhimento } \\
\text { institucional, familiar ou família substituta) }- \\
\text { art. 112, VII, do ECA). } \\
\text { MSE é somente para adolescentes. }\end{array}$ & $\begin{array}{l}\text { MEP é tanto para criança quanto para } \\
\text { adolescente nas } \\
\text { mencionadas. }\end{array}$ \\
\hline
\end{tabular}

As medidas, ditas protetivas, são justificadas não na proteção de interesses da sociedade ou de instituições, ${ }^{172}$ como a Família e a Igreja, mas sim no interesse da criança autora de crime, para a qual não há incidência de pena criminal.

Elas não se confundem nem podem se confundir com as medidas socioeducativas, sob pena de violação ao princípio de estrita legalidade que regula as sanções aplicadas pelo Estado ao autor de fato definido como crime. ${ }^{173}$

Importante salientar que a criança, ou seja, o menor de 12 anos nunca será passível de medidas socioeducativas, mas apenas de medidas de proteção (artigo 98 do $\mathrm{ECA}^{174}$ ), aplicáveis sempre que os direitos reconhecidos no ECA forem ameaçados ou violados. Elas buscam excluí-los do sistema de sancionamento aplicado aos adultos ${ }^{175}$, por estarem amparados pelo sistema especial de proteção devido sua peculiar condição de pessoa em desenvolvimento. Assim, apesar da Convenção sobre os Direitos da

\footnotetext{
${ }^{171}$ CERQUEIRA, Thales tácito Pontes Luz de Pádua. Manual do estatuto da criança e do adolescente (teoria e prática). $2^{\mathrm{a}}$ Ed. Niterói, RJ: Impetus, 2010. p. 309.

${ }^{172}$ Definida por BERGER como um padrão de controle, uma programação de conduta individual imposta pela sociedade, representada por papeis e experimentadas como algo dotado de realidade exterior, sendo algo situado fora do indivíduo. [O que é uma instituição social? Peter L. Berger e Brigitte Berger]

${ }^{173}$ MACHADO, Martha de Toledo. A proteção constitucional de crianças e adolescentes e os direitos humanos. São Paulo: Manole, 2003. p. 232.

${ }^{174}$ Art. 98. As medidas de proteção à criança e ao adolescente são aplicáveis sempre que os direitos reconhecidos nesta Lei forem ameaçados ou violados:

I - por ação ou omissão da sociedade ou do Estado;

II - por falta, omissão ou abuso dos pais ou responsável;

III - em razão de sua conduta.

${ }_{175}$ MACHADO, Martha de Toledo. A proteção constitucional de crianças e adolescentes e os direitos humanos. São Paulo: Manole, 2003. p. 233.
} 
Criança e do Adolescente ${ }^{176}$, considerar criança 'toda pessoa com idade inferior a 18 anos', no Brasil a classificação ocorre de maneira diversa. Aqui ainda há uma diferenciação entre criança e adolescente; todos aqueles com 12 anos completos passam a ser considerados adolescente e se tornam passíveis de aplicação de medida socioeducativa. Focaremos o restante da pesquisa em dados referentes a esta faixa etária, sua situação atual, trajetórias e perspectivas.

\section{a. O perfil do adolescente autor de infração}

A Projeção Populacional do Instituto Brasileiro de Geografia e Estatística (IBGE) mostrou que, em 2007, os jovens brasileiros com idade entre 15 e $29 \operatorname{anos}^{177}$ somavam 50,2 milhões de pessoas, ou seja, cerca de $26,4 \%$ da população total, sendo projetados para 2010, cerca de 51,3 milhões, tal como pode se verificar na seguinte tabela:

\begin{tabular}{|c|c|c|c|c|}
\hline \multicolumn{5}{|c|}{$\begin{array}{c}\text { Tabela } 1 \text { - População projetada total e de } 0 \text { a } 24 \text { anos de idade, por sexo, } \\
\text { segundo os grupos de idade Brasil - 2000/2020 }\end{array}$} \\
\hline \multirow[t]{2}{*}{ Grupos de Idade } & \multicolumn{4}{|c|}{ População projetada total e de 0 a 24 anos de idade } \\
\hline & 2000 & 2005 & 2010 & 2020 \\
\hline \multicolumn{5}{|c|}{ Total } \\
\hline População total & 167716538 & 179556501 & 190977109 & 210727174 \\
\hline 0 a 17 anos & 60413186 & 60216214 & 60849269 & 61536644 \\
\hline 0 a 6 anos & 23225510 & 23968407 & 24268186 & 23728275 \\
\hline Menos de 1 ano & 3416614 & 3500482 & 3477962 & 3417598 \\
\hline 1 a 4 anos & 13290303 & 13747930 & 13874497 & 13540236 \\
\hline 5 e 6 anos & 6518593 & 6719995 & 6915727 & 6770441 \\
\hline 7 a 14 anos & 26806941 & 26101020 & 26845087 & 27487699 \\
\hline 7 a 9 anos & 9707395 & 9894530 & 10248541 & 10236345 \\
\hline 10 e 11 anos & 6730975 & 6509941 & 6711852 & 6883484 \\
\hline 12 anos & 3440374 & 3246565 & 3317516 & 3452358 \\
\hline 13 e 14 anos & 6928197 & 6449984 & 6567178 & 6915512 \\
\hline 15 a 17 anos & 10380735 & 10146787 & 9735996 & 10320670 \\
\hline 15 anos & 3464330 & 3326181 & 3255298 & 3454343 \\
\hline 16 anos & 3459127 & 3391720 & 3243696 & 3442378 \\
\hline 17 anos & 3457278 & 3428886 & 3237002 & 3423949 \\
\hline 18 anos & 3458044 & 3446111 & 3235873 & 3402586 \\
\hline 19 anos & 3455463 & 3449101 & 3186822 & 3378432 \\
\hline 20 a 24 anos & 16478360 & 17153730 & 16918261 & 16453200 \\
\hline \multicolumn{5}{|c|}{ Homens } \\
\hline
\end{tabular}

\footnotetext{
${ }^{176}$ Aprovada pela Organização das Nações Unidas em 20 de Novembro de 1989 e ratificada pelo Brasil em 24 de setembro de 1990.

${ }^{177}$ Tal recorte etário é utilizado pela Secretaria Nacional de Juventude (SNJ) e pelo Conselho Nacional de Juventude (Conjuve), e é adotado na proposta de Estatuto da Juventude.
} 


\begin{tabular}{|c|c|c|c|c|}
\hline População total & 82384860 & 87995438 & 93393810 & 102636115 \\
\hline 0 a 17 anos & 30629192 & 30521942 & 30850248 & 31200907 \\
\hline 0 a 6 anos & 11784780 & 12161454 & 12313984 & 12041423 \\
\hline Menos de 1 ano & 1735535 & 1778020 & 1766592 & 1736072 \\
\hline $1 \mathrm{a} 4$ anos & 6742686 & 6974959 & 7039528 & 6870790 \\
\hline 5 e 6 anos & 3306559 & 3408475 & 3507864 & 3434561 \\
\hline 7 a 14 anos & 13589738 & 13223562 & 13608684 & 13935478 \\
\hline 7 a 9 anos & 4914363 & 5017642 & 5197056 & 5191459 \\
\hline 10 e 11 anos & 3411532 & 3300498 & 3402571 & 3489880 \\
\hline 12 anos & 1746648 & 1645668 & 1681407 & 1749862 \\
\hline 13 e 14 anos & 3517195 & 3259754 & 3327650 & 3504277 \\
\hline 15 a 17 anos & 5254674 & 5136926 & 4927580 & 5224006 \\
\hline 15 anos & 1756525 & 1682517 & 1648698 & 1749568 \\
\hline 16 anos & 1751073 & 1717584 & 1641708 & 1742438 \\
\hline 17 anos & 1747076 & 1736825 & 1637174 & 1732000 \\
\hline 18 anos & 1744235 & 1744719 & 1635710 & 1720079 \\
\hline 19 anos & 1739515 & 1744484 & 1600222 & 1706753 \\
\hline 20 a 24 anos & 8216247 & 8626419 & 8525747 & 8290042 \\
\hline \multicolumn{5}{|c|}{ Mulheres } \\
\hline População total & 85331678 & 91561063 & 97583299 & 108091059 \\
\hline 0 a 17 anos & 29783994 & 29694272 & 29999021 & 30335737 \\
\hline 0 a 6 anos & 11440730 & 11806953 & 11954202 & 11686852 \\
\hline Menos de 1 ano & 1681079 & 1722462 & 1711370 & 1681526 \\
\hline $1 \mathrm{a} 4$ anos & 6547617 & 6772971 & 6834969 & 6669446 \\
\hline 5 e 6 anos & 3212034 & 3311520 & 3407863 & 3335880 \\
\hline 7 a 14 anos & 13217203 & 12877458 & 13236403 & 13552221 \\
\hline 7 a 9 anos & 4793032 & 4876888 & 5051485 & 5044886 \\
\hline 10 e 11 anos & 3319443 & 3209443 & 3309281 & 3393604 \\
\hline 12 anos & 1693726 & 1600897 & 1636109 & 1702496 \\
\hline 13 e 14 anos & 3411002 & 3190230 & 3239528 & 3411235 \\
\hline 15 a 17 anos & 5126061 & 5009861 & 4808416 & 5096664 \\
\hline 15 anos & 1707805 & 1643664 & 1606600 & 1704775 \\
\hline 16 anos & 1708054 & 1674136 & 1601988 & 1699940 \\
\hline 17 anos & 1710202 & 1692061 & 1599828 & 1691949 \\
\hline 18 anos & 1713809 & 1701392 & 1600163 & 1682507 \\
\hline 19 anos & 1715948 & 1704617 & 1586600 & 1671679 \\
\hline 20 a 24 anos & 8262113 & 8527311 & 8392514 & 8163158 \\
\hline $\begin{array}{l}\text { rojeto IBGE/Fund } \\
\text { Integrado de Proj }\end{array}$ & as Naçõ & $\begin{array}{l}\text { Is - UNFI } \\
\text { s e Indic }\end{array}$ & $\begin{array}{l}\text { ASIL (BR } \\
\text { Sociodem }\end{array}$ & $\begin{array}{l}\text { P08), Sistema } \\
\text { cos. }\end{array}$ \\
\hline
\end{tabular}

Vemos que a tendência de crescimento da população jovem deverá se reverter, havendo uma redução progressiva no número absoluto de jovens no Brasil. Com relação aos dados referentes à renda, gênero, etnia e localização regional, os dados da Pesquisa Nacional por Amostra de Domicílios (PNAD) realizada pelo IBGE nos mostram que:

[...] 30,6\% dos jovens podem ser considerados pobres, pois vivem em famílias com renda domiciliar per capita de até meio salário mínimo (SM). De outra parte, apenas $15,7 \%$ são 
oriundos de famílias com renda domiciliar per capita superior a dois SMs e aproximadamente $53,7 \%$ pertencem ao extrato intermediário, com renda domiciliar per capita entre meio e dois SMs. Embora haja equilíbrio na distribuição dos jovens brasileiros por sexo - sendo 50\% homens e 50\% mulheres -, a pobreza é ligeiramente superior entre as mulheres jovens (53\%), tal como se dá para a população como um todo.

Por outro lado, observa-se que os jovens de baixa renda estão concentrados na região Nordeste (51,7\% do total do país), com destaque para o fato de que $19,3 \%$ da juventude nordestina é constituída de jovens pobres que vivem em áreas rurais. Notese, ainda, que os jovens pobres são majoritariamente não brancos (70,9\%), enquanto os jovens brancos são 53,9\% dos não pobres - embora a distribuição dos jovens brasileiros entre os grupos branco e não branco seja de $47,1 \%$ e $52,9 \%$, respectivamente. ${ }^{178}$

A pesquisa do IPEA 'Juventude e políticas sociais no Brasil' demonstra a grande disparidade existente entre os jovens que vivem em áreas urbanas $(84,8 \%)$ e aqueles que habitam o campo $(15,2 \%)$. Pois enquanto os primeiros convivem com altas taxas de desemprego, violência, além da crescente segregação espacial e qualidade de vida deteriorada, os jovens das áreas rurais lidam com questões específicas, como o esforço físico exigido pela atividade agrícola, as dificuldades de acesso a terra, expectativas relacionadas à reprodução da agricultura familiar e o celibato, além da falta de acesso a equipamentos públicos e condições de vida precárias (29\% dos jovens pobres do país).

Do total de jovens urbanos, $48,7 \%$ vivem em moradias inadequadas fisicamente. Como reflexo das restrições ao acesso à habitação nas grandes cidades brasileiras, observa-se que cerca de 2 milhões de jovens entre 15 e 29 anos vivem em favelas, sendo que a maior parte desta população é negra $(66,9 \%)$, enquanto $30,2 \%$ vivem em famílias com renda domiciliar per capita de até meio SM. ${ }^{179}$

O Departamento de Monitoramento e Fiscalização do Sistema Carcerário $\left(\mathrm{DMF} / \mathrm{CNJ}^{180}\right)$ através do "Programa Justiça ao Jovem", ao elaborar diagnóstico sobre o cumprimento das medidas socioeducativas de internação de jovens em conflito com a

\footnotetext{
${ }^{178}$ CASTRO, Jorge Abrahão de; AQUINO, Luseni Maria C. de; e ANDRADE, Carla Coelho de (Org). Juventude e políticas sociais no Brasil. Brasília: Ipea, 2009. p. 31-32.

${ }^{179}$ CASTRO, Jorge Abrahão de; AQUINO, Luseni Maria C. de; e ANDRADE, Carla Coelho de (Org). Juventude e políticas sociais no Brasil. Brasília: Ipea, 2009. p. 33.

${ }^{180}$ O Departamento de Monitoramento e Fiscalização do Sistema Carcerário e do Sistema de Execução de Medidas Socioeducativas (DMF) foi criado pela Lei n. 12.106, de 2 de dezembro de 2009.
} 
lei, mapeou ${ }^{181}$ o funcionamento dos estabelecimentos de internação e das varas da infância e juventude com atribuição de fiscalização destas unidades em todos os estados e no Distrito Federal.

Neste diagnóstico buscou-se analisar o perfil dos adolescentes em cumprimento de medida socioeducativa de internação; examinar a tramitação dos processos de execução das medidas socioeducativas; avaliar o ordenamento territorial dos estabelecimentos; e conhecer as instituições de internação a fim de analisar se aos adolescentes sob custódia do Estado são garantidos os direitos abrigados no Estatuto da Criança e do Adolescente (ECA) e no Sistema Nacional de Atendimento Socioeducativo (SINASE)

Ao traçar um perfil do adolescente em conflito com a lei vemos que esta possui idade média de 16,7 anos, de modo que se considerado o período máximo de internação, boa parte dos jovens internados alcança a maioridade civil e penal durante o cumprimento da medida.

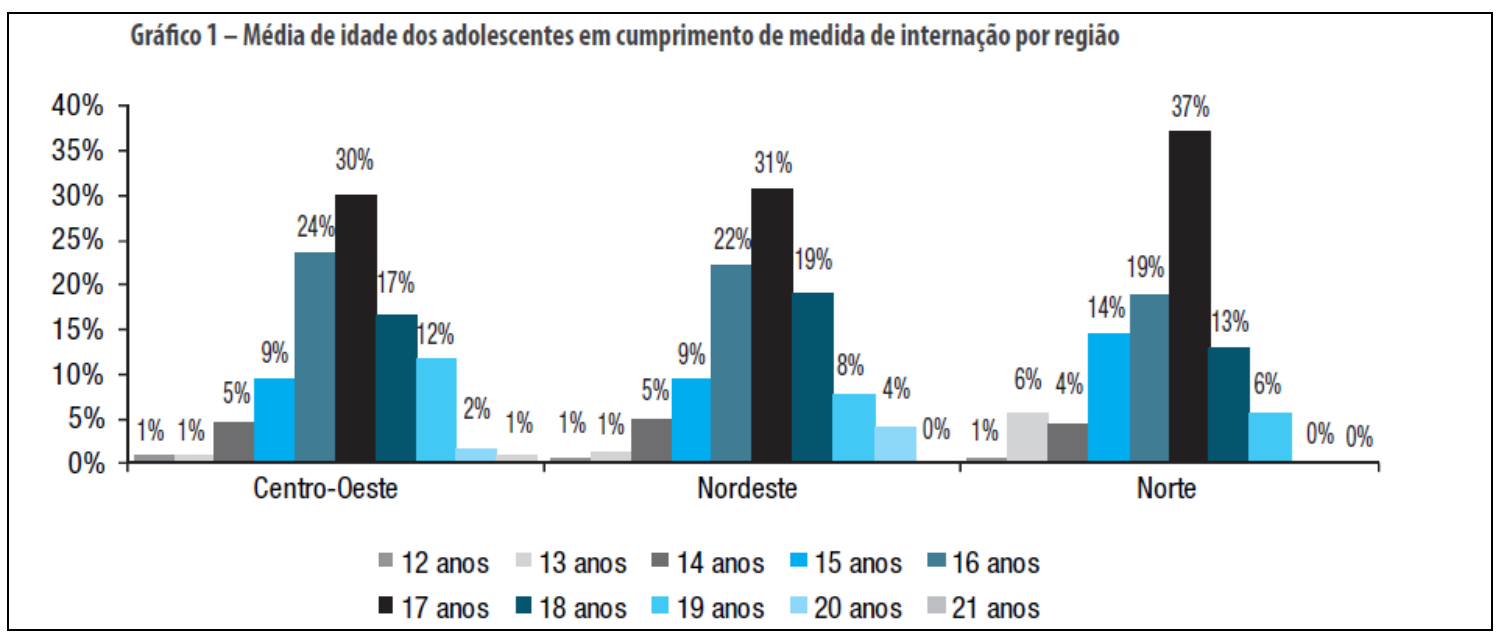

${ }^{181}$ O mapeamento foi realizado por equipe composta por juízes, servidores de cartórios judiciais e técnicos do Judiciário da área de assistência social, psicologia e pedagogia, que percorreu 320 estabelecimentos de internação no Brasil, durante o período de 19/7/2010 a 28/10/2011, a fim de analisar as condições de internação de 17.502 adolescentes que cumpriam medida socioeducativa de restrição de liberdade. 


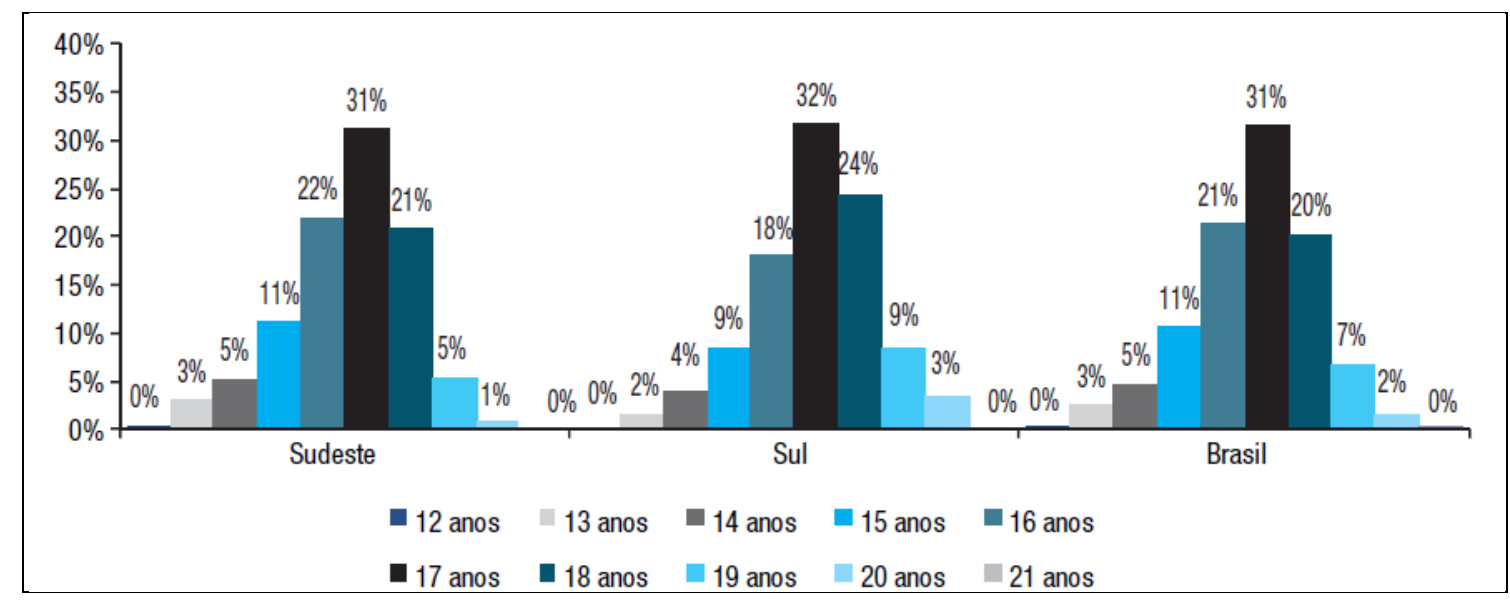

Fonte: DMF/CNJ - Elaboração: DPJ/CNJ

Segundo o diagnóstico, 47,5\% dos adolescentes cometeu o primeiro ato infracional entre 15 e 17 anos; 42,6\% entre 12 e 14 anos; e 9\% entre os 07 e 11 anos de idade.

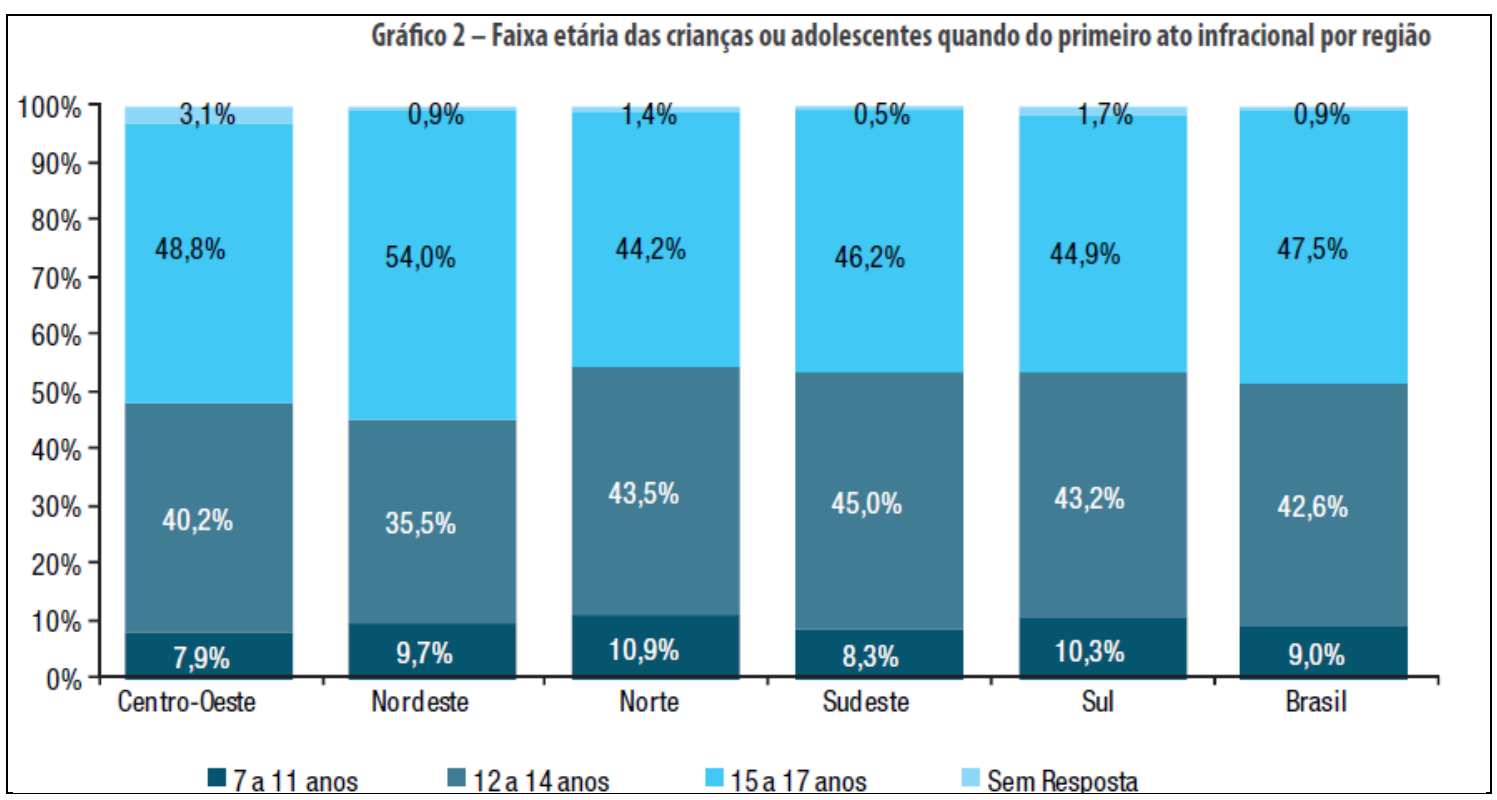

Fonte: DMF/CNJ - Elaboração: DPJ/CNJ

O relatório ainda nos mostra que os adolescentes cumprem medida de internação por atos infracionais correspondentes a crimes contra o patrimônio (roubo, furto, entre outros). Obtendo o roubo os mais altos percentuais (de 26\% na Região Sul, a $40 \%$ na Região Sudeste) dos delitos praticados. O crime de homicídio foi expressivo em todas as regiões do país, com exceção do Sudeste 7\%, sendo que nas regiões Sul, Centro-Oeste, Nordeste e Norte, o percentual varia de $20 \%$ a $28 \%$. 
O tráfico de drogas se destacou nas regiões Sudeste e Sul (segundo ato infracional mais praticado) representando $32 \%$ e $24 \%$, respectivamente. Por sua vez, estupro, furto, lesão corporal e roubo seguido de morte obtiveram menores proporções.

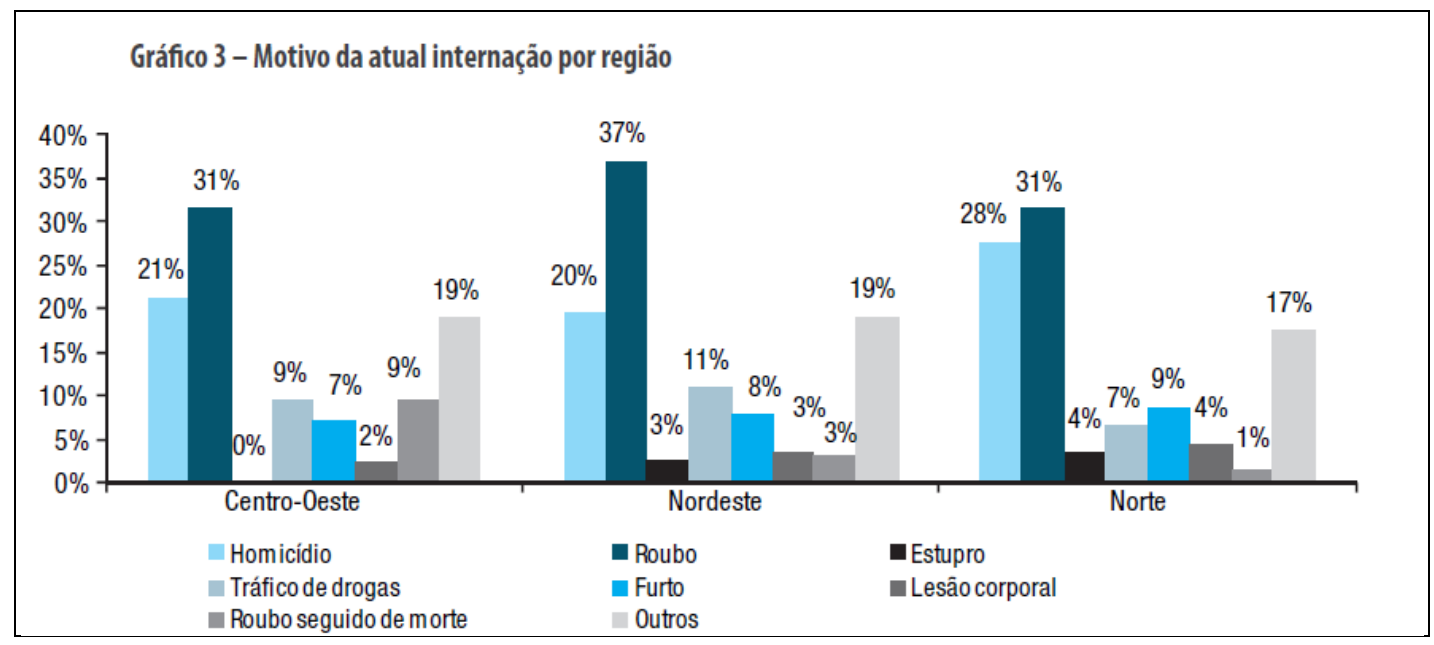

Fonte: DMF/CNJ - Elaboração: DPJ/CNJ

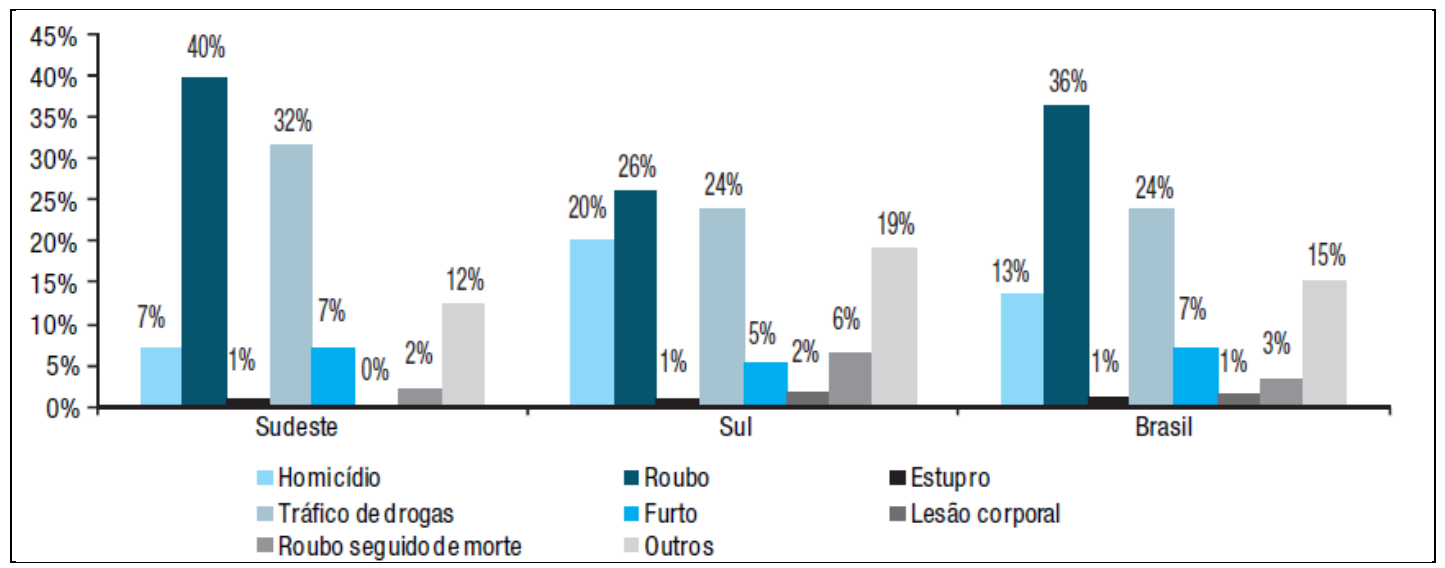

Fonte: DMF/CNJ - Elaboração: DPJ/CNJ

Mais especificamente em relação à reincidência, 43,3\% dos adolescentes já haviam sido internados ao menos uma outra vez. Na região Nordeste este índice registra $54 \%$, enquanto na Centro-Oeste $45,7 \%$. Nas demais regiões, ele varia entre $38,4 \%$ e $44,9 \%$. 


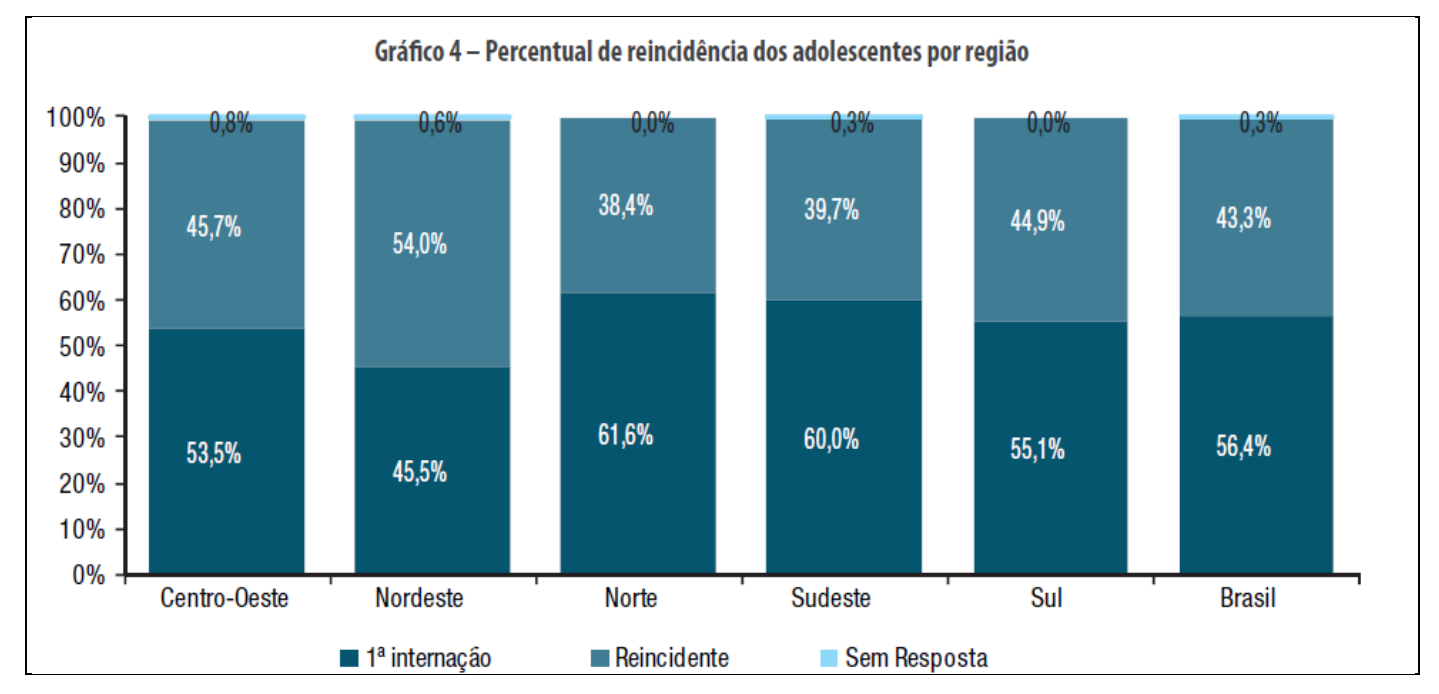

Fonte: DMF/CNJ - Elaboração: DPJ/CNJ

Com relação à escolaridade o diagnóstico do $\mathrm{CNJ}$ revela que $8 \%$ do percentual de adolescentes entrevistados era de não alfabetizados.

Observa-se que este índice nacional comporta uma disparidade entre as regiões, considerando que no Nordeste $20 \%$ dos adolescentes entrevistados declararam-se analfabetos, enquanto no Sul e no Centro-Oeste, $1 \%$. Tais regiões destacam-se por apresentar índice de 98\% de adolescentes infratores alfabetizados. No contexto nacional, entre todos os adolescentes analfabetos, $44 \%$ destes encontram-se na Região Nordeste. ${ }^{182}$

O gráfico a seguir mostra a diferença entre a porcentagem de adolescentes alfabetizados nas regiões Sul e Centro-Oeste em comparação com a região Nordeste, que aparece com as maiores porcentagens:

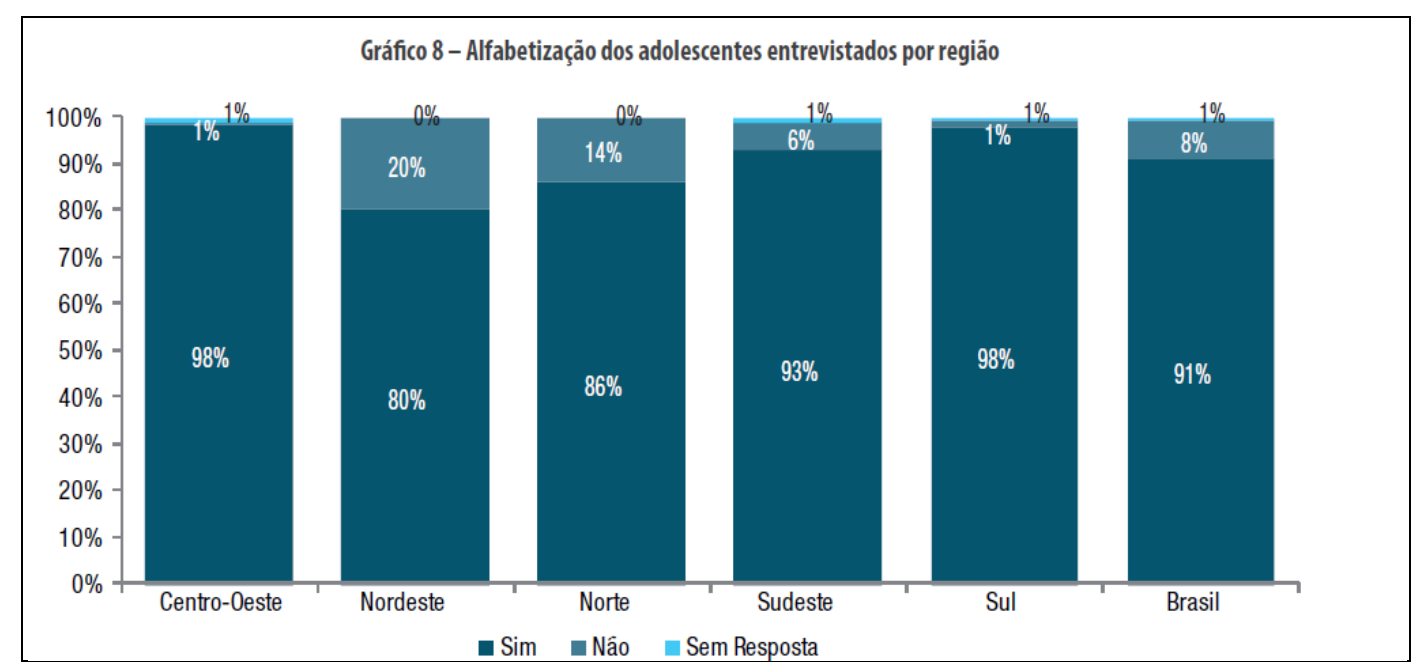

Fonte: DMF/CNJ - Elaboração: DPJ/CNJ

182 CONSElHO NACIONAL DE JUVENTUDE, Panorama Nacional. A Execução das Medidas Socioeducativas de Internação Programa Justiça ao Jovem. CNJ, 2012. 
A maioria dos adolescentes internados apresenta um baixo grau de escolaridade, não chegando ao ensino médio. Assim, a maioria declarou ter parado de estudar entre 08 e 16 anos (média de 14 anos).
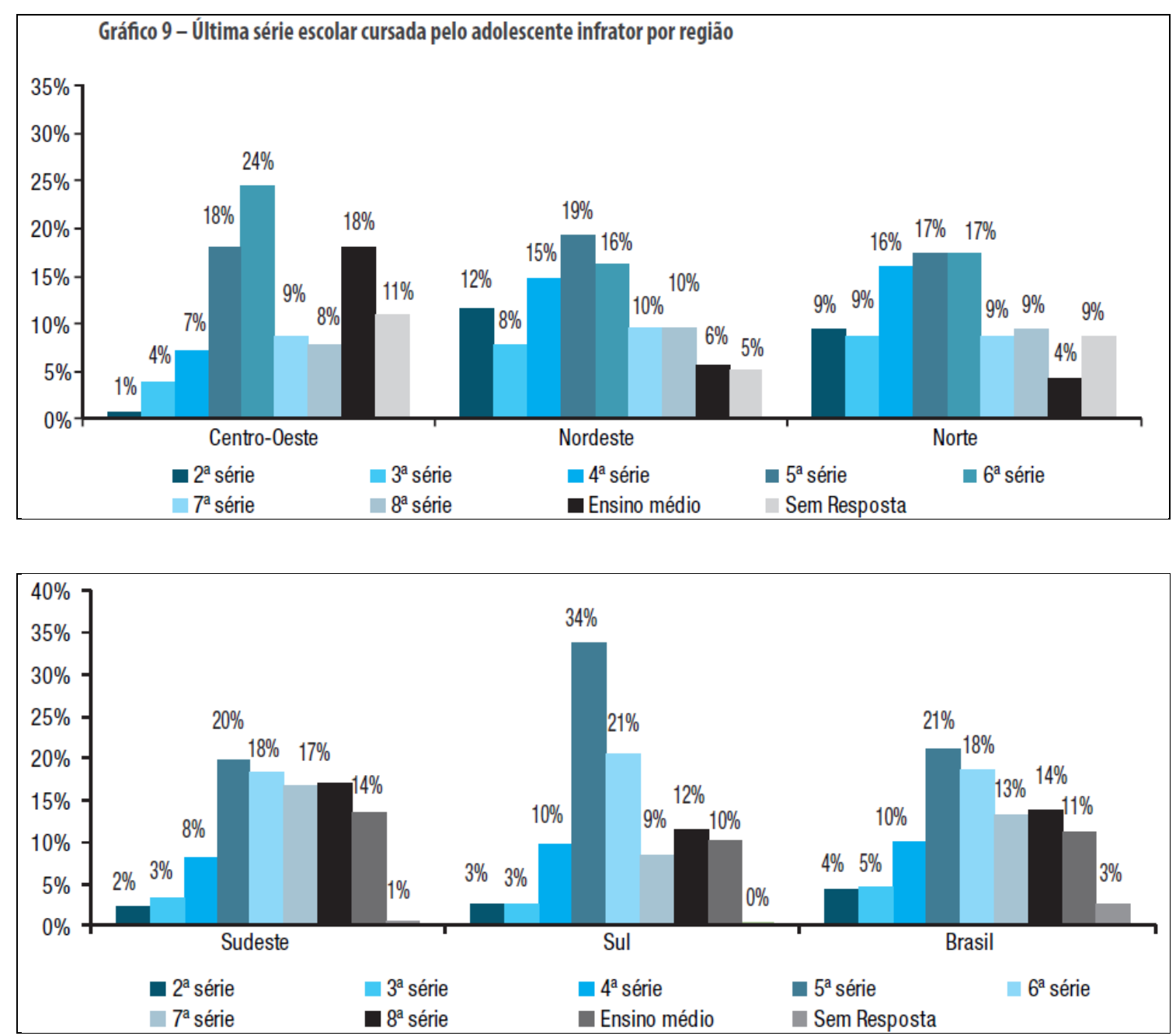

Fonte: DMF/CNJ - Elaboração: DPJ/CNJ

Muitos dos jovens que cumprem medida socioeducativa de internação (57\%) declararam não que não frequentavam mais a escola antes do ingresso na unidade de internação. Sendo a última série cursada por $86 \%$ dos adolescentes o ensino fundamental 


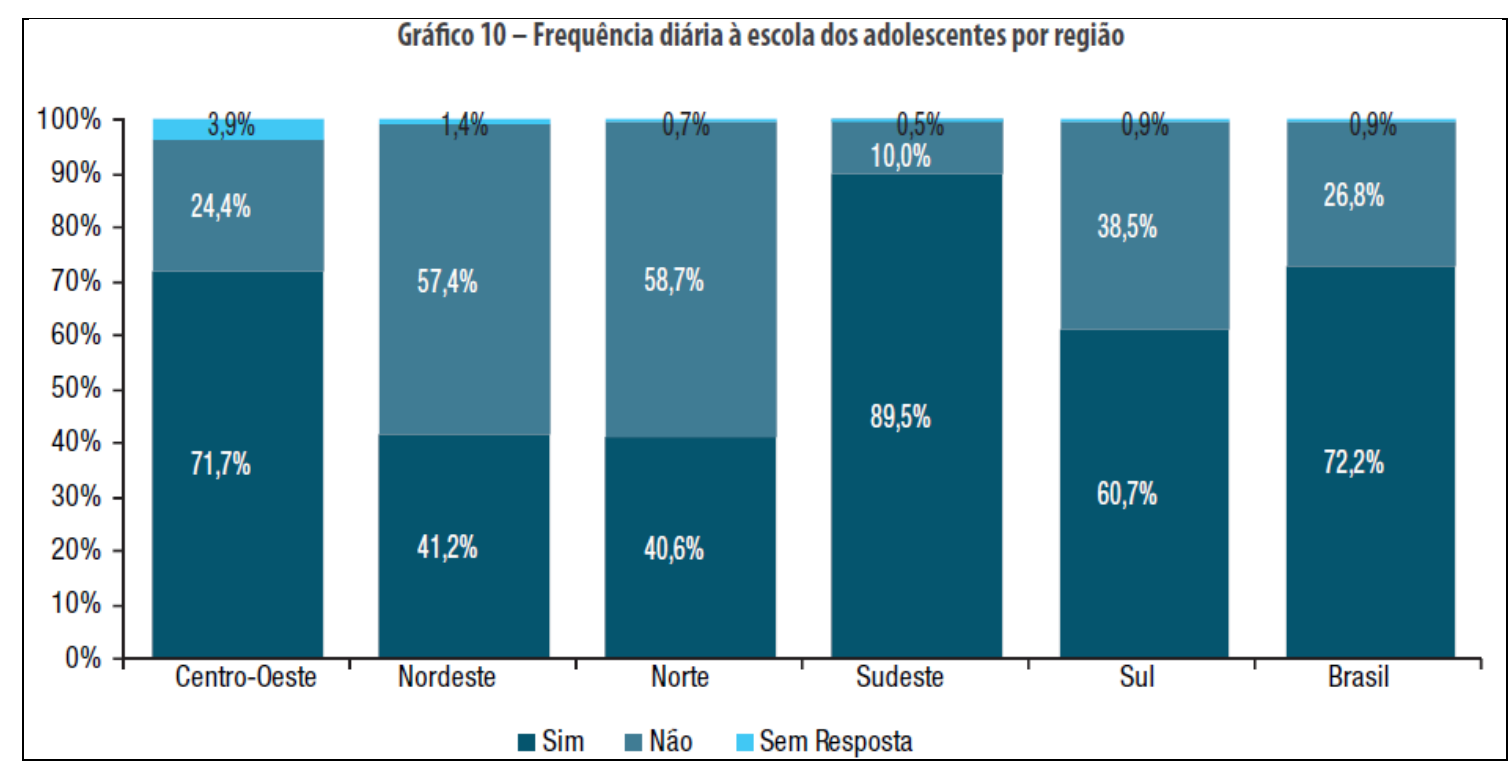

Fonte: DMF/CNJ - Elaboração: DPJ/CNJ

Em relação às relações familiares, $43 \%$ foram criados apenas pela mãe, $4 \%$ apenas pelo pai, $38 \%$ por ambos e $17 \%$ pelos avós, podendo estes jovens ter sido criados por mais de um ente familiar. Já em relação ao uso de substâncias psicoativas, 75\% dos adolescentes faziam uso de drogas ilícitas, principalmente na Região CentroOeste $\left(80,3 \%\right.$, sendo a maconha a substância mais citada) ${ }^{183}$.

Concluímos, assim, pela responsabilidade estrutural da sociedade, que exclui social, cultural e economicamente estes adolescentes em situação de conflito. No relatório apresentado pelo CNJ questões como famílias desestruturadas, defasagem escolar e utilização de substâncias psicoativas são apontadas como causadoras do ato infracional e envolvimento criminal. Ocorre que não apenas esses fatores podem ser justificadores da prática de ato infracional, já que se observarmos que a maioria dos delitos cometidos se refere a crimes contra o patrimônio podemos inferir o desejo de inclusão em uma sociedade capitalista, na qual apenas o consumo/ a propriedade pode ser a chave para o reconhecimento destes jovens tão privados de tudo.

\section{b. Trajetória de vitimização do adolescente autor de infração}

A Resolução 40/34 da Assembleia Geral das Nações Unidas, de 29 de novembro de 1985, conceitua vítima como sendo a

\footnotetext{
${ }^{183}$ Panorama Nacional. A Execução das Medidas Socioeducativas de Internação Programa Justiça ao Jovem. CNJ, 2012.
} 
pessoa que, individual ou coletivamente, tenha sofrido danos, inclusive lesões físicas ou mentais, sofrimento emocional, perda financeira ou diminuição substancial de seus direitos fundamentais, como consequências de ações ou omissões que violem a legislação penal vigente, nos Estados- Membros, incluída a que prescreve o abuso de poder

Sendo a vitimização, o processo vitimizatório, ou seja, a ação ou efeito de alguém vir a ser vítima de sua própria conduta ou da conduta de terceiro, ou fato da natureza.

As crianças e os adolescentes representam $34 \%$ da população brasileira, ou seja, um contingente de 57,1 milhões de pessoas em números absolutos. ${ }^{184}$ Aproximadamente metade das crianças e dos adolescentes do Brasil - 48,8\% e 40\%, respectivamente - é considerada pobre ou miserável. Além da pobreza, estas são expostas a diversos fatores que reforçam ainda mais a situação de vulnerabilidade em que se encontram e as vitimizam:

A questão principal que consolida o argumento da vitimação é seu caráter desencadeador da agressão física ou sexual contra crianças, tendo em conta que a cronificação da pobreza da família contribui para a precarização e deterioração de suas relações afetivas e parentais. Nesse sentido, pequenos espaços, pouca ou nenhuma privacidade, falta de alimentos e problemas econômicos acabam gerando situações estressantes que, direta ou indiretamente, acarretam danos ao desenvolvimento infantil. $^{185}$

Nos ensinamentos de VIOLANTE,

[...] as causas da marginalidade não podem ser procuradas no mundo próximo do indivíduo, nos fatores pessoais e psicológicos, mas na estrutura social. As variáveis causais essenciais para a compreensão da marginalidade são os processos econômicos [...] Considerar a marginalidade como fenômeno psicológico individual e o indivíduo seu portador constitui uma das condições para a sua reprodução. Isto porque, na medida em que se toma a marginalidade por suas manifestações, perdem-se de vista suas raízes, encontradas nas condições estruturais da sociedade. ${ }^{186}$

${ }^{184}$ SILVA. Enid Rocha Andrade da. "O perfil da criança e do adolescente nos abrigos pesquisados". In. SILVA. Enid Rocha Andrade da (Coord.). O Direito à Convivência Familiar e Comunitária: os abrigos para crianças e adolescentes no Brasil. Brasília : IPEA/CONANDA, 2004.

${ }^{185}$ GUERRA e AZEVEDO. Infância e violência doméstica: fronteiras do conhecimento. 2 ed. São Paulo: Cortez, 1997. apud AMARO, Sarita. Crianças vítimas da violência: das sombras do sofrimento à genealogia da resistência. Uma nova teoria científica. Porto Alegre: AGE/EDIPURS, 2003.

${ }_{186}$ VIOLANTE, Maria Lúcia Vieira. O dilema do decente malandro. São Paulo, Cortez-Autores Associados, 1982, p. 22. 
Através de dados extraídos do banco de dados da Fundação CASA, DT/NUPRIE, em 20 de abril de 2010, podemos observar o perfil dos adolescentes atendidos pela Fundação: idade predominante entre 16 e 18 anos, com escolaridade aquém de sua idade cronológica, envolvidos diretamente ou indiretamente com $\operatorname{drogas}^{187}$.

Esta intensa relação com a violência continua com a internação, visto que há ampla utilização da tortura psicológica nas unidades, conforme revela o Diagnóstico do CNJ:

Dos dados, destaca-se o número de estabelecimentos que registraram situações de abuso sexual sofrido pelos internos: em 34 estabelecimentos pelo menos um adolescente foi abusado sexualmente nos últimos 12 meses. Em 19 estabelecimentos há registros de mortes de adolescentes em cumprimento de medidas socioeducativas.

Além disso, sete estabelecimentos informaram a ocorrência de mortes por doenças preexistentes e dois registraram mortes por suicídio nos últimos 12 meses. A violência sofrida por adolescentes no interior dos estabelecimentos enseja mais atenção do Estado, visto que é seu dever a proteção e a garantia das condições básicas para o desenvolvimento das crianças e dos adolescentes.

[...] Além desses crimes, outra situação preocupante é a violência física sofrida pelos adolescentes. Dos jovens entrevistados em conflito com a lei, $28 \%$ declararam ter sofrido algum tipo de agressão física por parte dos funcionários, $10 \%$ por parte da Polícia Militar dentro da unidade da internação e $19 \%$ declararam ter sofrido algum tipo de castigo físico dentro do estabelecimento de internação. ${ }^{188}$

Por mais que se fale que a medida socioeducativa de internação não possua caráter eminentemente punitivo, mas que busca responsabilizar o adolescente pelas consequências lesivas do ato infracional - tendo como objetivo sua ressocialização e a reparação do ato -, é perceptível a semelhança que a sanção imposta ao adolescente, pela prática de fato definido como crime, guarda com a pena criminal. Tal perspectiva é corroborada por MACHADO:

Vejo identidade da medida socioeducativa com a pena criminal na medida em que ambas comportam privação de liberdade; ou

\footnotetext{
${ }^{187}$ Dados retirados do sítio eletrônico: http://www.fundacaocasa.sp. gov.br/ Acesso em 12.07.2011.

188 Panorama Nacional. A Execução das Medidas Socioeducativas de Internação Programa Justiça ao Jovem. CNJ, 2012.p. 127-128.
} 
seja, comportam, na essência e em sentido genérico, reação aflitiva à ofensa, nas palavras de Ferrajoli. E medida aflitiva que se impõe ao autor do crime, de um lado, como forma de lograr prevenção dos delitos; por outro, objetivando lograr a paz social pelo mecanismo de resposta estatal ao crime, que busca inibir a resposta individual do ofendido ou seus 'apoiadores' resposta não jurídica e não pública, portanto, violenta, ilimitada e selvagem - contra o autor do fato penal típico, ou inibir a 'resposta pública' não limitada por um sistema constitucional de garantias do cidadão. ${ }^{189}$

Afinal, é sabido que as consequências do cárcere são graves, para o adulto privado de liberdade, imagine-se quando se trata de adolescentes ainda em processo formativo.

Toda medida de efeito estigmatizante é mais grave para o adolescente do que para o adulto, pois pode mais facilmente afetar a autoestima da pessoa, levando-a a assumir uma conduta desviante em função de sua autopercepção, provocada iterativamente pela reação das pessoas que a rodeiam ou com as quais trata ${ }^{190}$.

Insta salientar que o critério para se estabelecer a idade penal mínima é político, não se relacionando à capacidade ou incapacidade de entendimento da criança e do adolescente. ${ }^{191}$ As diversas formas de violência impingidas durante o cumprimento da pena restritiva de liberdade acabam tornando a internação tal qual ESPINOZA define a prisão:

[...] uma instituição de sequestros: sequestra-se não só a liberdade ambulatória dos homens e mulheres que a ela são submetidos como também a voz, a identidade, a dignidade, a condição de sujeitos e cidadãos [...] As interações no cárcere, mesmo feminino, se reproduzem pela regra do medo, ou seja, a doutrina de prêmios e castigos é reconstruída na sua versão mais perversa, visto que não se apela ao estímulo, mas à coerção, para produzir alterações na conduta das pessoas. A disciplina converte-se então em mecanismo justificado para o incremento do sofrimento. [...]. ${ }^{192}$

\footnotetext{
${ }^{189}$ MACHADO, Martha de Toledo. A proteção constitucional de crianças e adolescentes e os direitos humanos. São Paulo: Manole, 2003. p. 239.

190 ZAFFARONI, Raul, in CURY, Munir (Org). Estatuto da Criança e do Adolescente comentado. Malheiros Editores, 2008. p. 803.

${ }^{191}$ TERRA, Eugênio Couto. "A idade penal mínima como cláusula pétrea". In: A razão da idade: mitos e verdades. $1^{a}$ Edição. Coleção Garantias de Direitos. Série Subsídios Tomo VII. Brasília: MJ/SEDH/DCA, 2001.p. 53.

${ }^{192}$ ESPINOZA, Olga. A mulher encarcerada em face do poder punitivo. São Paulo: IBCCrim, 2004. p. 148.
} 
Não se pode tolerar que o espaço simbolicamente reservado para a reabilitação do indivíduo, e cujo tutor é o Estado, permita que os internados sofram lesões físicas, mentais, Além da diminuição substancial de seus direitos fundamentais, fato que se configura como flagrante violação da legislação penal juvenil vigente, muitas vezes tornando estes adolescentes vítimas do cumprimento de medidas socioeducativas. 


\section{III - A LEI, A INFRAÇÃO E A PUNIÇÃO}

1. A medida socioeducativa. 2. O sistema de cumprimento de medidas socioeducativas.

\section{A medida socioeducativa}

As medidas socioeducativas, decorrem estritamente da prática do fato definido na lei penal como crime: é o que aflora insofismavelmente dos artigos 103 e 112, caput, do ECA, na medida em que o primeiro conceitua o ato infracional como 'a conduta descrita como crime ou contravenção penal' e o segundo reza que as medidas socioeducativas são aplicáveis 'verificada a prática de ato infracional'. Esta medidas ${ }^{193}$ se dividem no binômio punir e educar. Há quem diga que elas visam "favorecer a reintegração e reeducação do adolescente" ${ }^{\text {194 }}$, mas tal discurso não é aceito na criminologia crítica, já que o prefixo "re" tem conotação de repetição e muitos destes adolescentes em conflito com a lei na maioria das vezes não foram anteriormente nem integrados, nem educados (educação formal) antes de delinquir.

As medidas socioeducativas podem ser aplicadas isolada ou cumulativamente. Sua aplicação é ainda repleta de lacunas e controvérsias, tanto que o Estatuto da Criança e do Adolescente, até pouco tempo atrás, não possuía um sistema de execução de MSEs, tal qual ocorre na Lei de Execução Penal. Esta demora se deu devido à grande discussão sobre a localização do sistema de punição juvenil, se parte do sistema penal, se parte do chamado sistema penal juvenil, se parte do sistema de

\footnotetext{
${ }^{193}$ Art. 112. Verificada a prática de ato infracional, a autoridade competente poderá aplicar ao adolescente as seguintes medidas:

I - advertência;

II - obrigação de reparar o dano;

III - prestação de serviços à comunidade;

IV - liberdade assistida;

V - inserção em regime de semi-liberdade;

VI - internação em estabelecimento educacional;

VII - qualquer uma das previstas no art. 101, I a VI.

$\S 1^{\circ}$ A medida aplicada ao adolescente levará em conta a sua capacidade de cumpri-la, as circunstâncias e a gravidade da infração.

$\S 2^{\circ}$ Em hipótese alguma e sob pretexto algum, será admitida a prestação de trabalho forçado.

$\S 3^{\circ}$ Os adolescentes portadores de doença ou deficiência mental receberão tratamento individual e especializado, em local adequado às suas condições.

${ }_{194}$ CERQUEIRA, Thales tácito Pontes Luz de Pádua. Manual do estatuto da criança e do adolescente (teoria e prática). $2^{\text {a }}$ Ed. Niterói, RJ: Impetus, 2010. p. 369.
} 
proteção da criança e do adolescente, conforme crítica feita por PIOVESAN sobre o tema:

Se o artigo 227, parágrafo $3^{\circ}$ demanda, quando da aplicação de medida privativa de liberdade, um regime especial pautado pelos princípios da brevidade, excepcionalidade e respeito à condição peculiar de pessoa em desenvolvimento, esse regime não pode ser o do Código Penal. ${ }^{195}$

Apenas recentemente - com a criação do Sistema Nacional de Atendimento Socioeducativo (SINASE), pela lei no 12.594 , de 18 de janeiro de 2012 - a execução das medidas socioeducativas destinadas a adolescentes que pratiquem ato infracional, passou a ser regulamentada. Esta regulamentação dispõe sobre os objetivos da MSE, as competências de cada ente federado, os planos e programas de atendimento socioeducativo, suas avaliações e acompanhamentos, bem como os procedimentos da MSE e os direitos ${ }^{196}$ dos adolescentes que a cumprem.

Tal regulamentação é de extrema importância, visto que a lei ordinária (ECA) ficou aquém do texto constitucional ao tecer considerações sobre a natureza da sanção, sendo tímida quanto aos direitos-garantias de natureza penal. MACHADO demonstra sua preocupação com a faceta educativa da MSE que se aplica ao autor do fato definido como crime ser insuficientemente tratada na lei ordinária.

\footnotetext{
${ }^{195}$ PIOVESAN, Flávia. "A inconstitucionalidade da redução da maioridade penal”. In: A razão da idade: mitos e verdades. $1^{a}$ Edição. Coleção Garantias de Direitos. Série Subsídios Tomo VII. Brasília: MJ/SEDH/DCA, 2001. p. 74-75.

${ }^{196}$ CAPÍTULO III - DOS DIREITOS INDIVIDUAIS
}

Art. 49. São direitos do adolescente submetido ao cumprimento de medida socioeducativa, sem prejuízo de outros previstos em lei:

I - ser acompanhado por seus pais ou responsável e por seu defensor, em qualquer fase do procedimento administrativo ou judicial;

II - ser incluído em programa de meio aberto quando inexistir vaga para o cumprimento de medida de privação da liberdade, exceto nos casos de ato infracional cometido mediante grave ameaça ou violência à pessoa, quando o adolescente deverá ser internado em Unidade mais próxima de seu local de residência;

III - ser respeitado em sua personalidade, intimidade, liberdade de pensamento e religião e em todos os direitos não expressamente limitados na sentença;

IV - peticionar, por escrito ou verbalmente, diretamente a qualquer autoridade ou órgão público, devendo, obrigatoriamente, ser respondido em até 15 (quinze) dias;

V - ser informado, inclusive por escrito, das normas de organização e funcionamento do programa de atendimento e também das previsões de natureza disciplinar;

VI - receber, sempre que solicitar, informações sobre a evolução de seu plano individual, participando, obrigatoriamente, de sua elaboração e, se for o caso, reavaliação;

VII - receber assistência integral à sua saúde, conforme o disposto no art. 60 desta Lei; e

VIII - ter atendimento garantido em creche e pré-escola aos filhos de 0 (zero) a 5 (cinco) anos.

$\S 1^{\circ}$ As garantias processuais destinadas a adolescente autor de ato infracional previstas na Lei $n^{\circ} 8.069$, de 13 de julho de 1990 (Estatuto da Criança e do Adolescente), aplicam-se integralmente na execução das medidas socioeducativas, inclusive no âmbito administrativo.

$\S 2^{\circ} \mathrm{A}$ oferta irregular de programas de atendimento socioeducativo em meio aberto não poderá ser invocada como motivo para aplicação ou manutenção de medida de privação da liberdade. 
[...] porque o Estatuto não pormenorizou suficientemente o conteúdo, e, portanto, o contorno jurídico, da medida socioeducativa. Na pormenorização que fez, a lei ocupou-se muito mais em ditar as limitações do poder restritivo do Estado da liberdade do adolescente, consubstanciada na faceta denominada 'sócio' da medida (v.g., art. 124, VI, VII, VIII, IX, X, XI, XII, XIII, XIV E XV), do que em definir com precisão o que seria a faceta educativa.

\section{$[\ldots]$}

As referências a ela na lei ordinária quase se resumem a nomeála: deu-se o nome socioeducativa às medidas, mas não se pormenorizou minimamente em que consistiria a educação ${ }^{197}$.

Vemos assim, a importância do estabelecimento preciso de limites de incidência entre as medidas de proteção e as medidas socioeducativas, principalmente no que tange ao seu objetivo, procedimento, cumprimento e avaliação.

\section{a. Definição}

O ECA prevê a aplicação de medidas socioeducativas que se podem ser desde advertência, prestação de serviço à comunidade até a privação de liberdade, sendo o ECA considerado uma das legislações mais modernas com relação aos objetivos da ressocialização e da educação dos adolescentes em conflito com a lei. Tanto que TELLES e GRAU atribuem a este avanço, a participação da sociedade civil na reeducação dos jovens e a necessidade desta relação estreita com o meio comunitário.

Experiências bem-sucedidas realizadas em diversos pontos do país demonstram claramente que uma aplicação correta das medidas socioeducativas, feita em conjunto com os familiares do menor, com a comunidade e com organizações não governamentais, resulta em redução significativa da criminalidade juvenil. Tanto é assim que o índice de reincidência dos adolescentes submetidos a medidas (incluindose a internação em estabelecimentos como a Febem) perfaz $7,5 \%$ (sete e meio por cento), enquanto que, no sistema carcerário, $47 \%$ (quarenta e sete por cento) de todos os egressos voltam a delinquir. ${ }^{198}$

\footnotetext{
${ }^{197}$ MACHADO, Martha de Toledo. A proteção constitucional de crianças e adolescentes e os direitos humanos. São Paulo: Manole, 2003. p. 248-249.

${ }^{198}$ TELLES Jr., Goffredo da Silva; GRAU, Eros Roberto. "A desnecessária e inconstitucional redução da maioridade penal". In: A razão da idade: mitos e verdades. $1^{a}$ Edição. Coleção Garantias de Direitos. Série Subsídios Tomo VII. Brasília: MJ/SEDH/DCA, 2001. p. 97-98.
} 
O significado material da MSE está relacionado à sua essência, o "ser" de seu objeto, sendo seus elementos informadores a unilateralidade e a obrigatoriedade ${ }^{199}$. Isto porque o jovem em conflito com a lei que receberá a MSE está em posição de subordinação perante o juiz que aplicará a medida, pois esta prescinde sua vontade, e o exercício deste poder sancionatório e coercitivo é consequente do ato infracional. Nas palavras de KONZEN:

A definição do significado material da medida socioeducativa deve levar em conta o efeito produzido no individuo destinatário de uma determinação unilateral e obrigatória, com origem numa decisão de mérito sobre a conformação de determinado comportamento à norma de vedação e que atinge, como reação, a liberdade de autodeterminação do indivíduo destinatário, restringindo-o em sua liberdade ou privando-o da sua liberdade ${ }^{200}$.

Assim, como o ato infracional é, conforme o disposto no artigo $103^{201}$ do ECA, sinônimo ao crime, o efeito a ser produzido pela MSE será idêntico ao da pena criminal. Em que pese parte da doutrina e da magistratura não aceitar esta vinculação das MSEs às penas, buscando crer no caráter "protetivo" e "tutelar" da medida, ela está intimamente relacionada à punição, havendo a denominação Direito Penal Juvenil para o direito responsável pela defesa e acompanhamento da aplicação, cumprimento e manutenção da MSE.

Aqueles que negam o sentido aflitivo da MSE vendo apenas um caráter tutelar e até pedagógico, ainda guardam muito da doutrina menorista da situação irregular, esquecendo-se do novo paradigma da proteção integral, que busca responsabilizar o jovem por seus atos.

Há ainda aqueles que tentam diferenciar a utilização dos vocábulos "pena" e "sanção", acreditando ser o primeiro relacionado à pena criminal destinada aos adultos, enquanto o segundo compreenderia uma responsabilização; diferenciação inexistente no sentido gramatical, bem como no jurídico. NUCCI demonstra a irrelevância jurídica de tal distinção ao definir pena como "a sanção imposta pelo estado"202 baseando-se no fato de seu sentido subjetivo (área do "dever ser") ser o mesmo para ambos, qual seja:

\footnotetext{
199 KONZEN, Afonso Armando. Pertinência Socioeducativa. Reflexões sobre a natureza jurídica das medidas. Porto Alegre: Livraria do Advogado Ed., 2005. p. 51-52.

${ }^{200}$ KONZEN, Afonso Armando. Pertinência Socioeducativa. Reflexões sobre a natureza jurídica das medidas. Porto Alegre: Livraria do Advogado Ed., 2005. p. 53.

${ }^{201}$ Art. 103. Considera-se ato infracional a conduta descrita como crime ou contravenção penal.

${ }^{202}$ NUCCI, Guilherme de Souza. Código Penal Comentado. São Paulo: Editora Revista dos Tribunais, 2008. p. 307.
} 
"a compreensão das consequências do descumprimento de dever normatizado"203. Ainda sobre esta discussão semântica, KONZEN afirma:

A medida socioeducativa, seja pena, seja sanção, significa, para o seu destinatário, a reprovação pela conduta ilícita, providências subsequente que carrega em si, seja a consequência restritiva ou privativa de liberdade, ou até mesmo modalidade de simples admoestação, o peso da aflição, porque sinal de reprovação, sinônimo de sofrimento porque sinal de reprovação, sinônimo de sofrimento porque segrega do indivíduo um, de seus bens naturais mais valiosos, a plena disposição e exercício da liberdade. ${ }^{204}$

\section{Como definia FRAGOSO ${ }^{205}$ :}

A sanção característica da lei penal, ou seja, a pena, não consiste na execução coativa do preceito jurídico violado, mas na perda de um bem jurídico imposta ao autor do ilícito, ou seja, num mal infligido ao réu, em virtude de seu comportamento antijurídico. Daí seu caráter retributivo. A denominação 'Direito Penal' surge justamente da sanção jurídica desse ramo do direito.

Assim, reconhecendo este caráter sancionatório das MSEs, é preciso que elas sejam aplicadas excepcionalmente (excepcionalidade), dentro da lei e da normativa do sistema de proteção da criança e do adolescente (legalidade), bem como em curtos espaços de tempo (brevidade).

O ECA possui um modelo de responsabilidade penal juvenil nas medidas socioeducativas de modo a responsabilizar o adolescente autor de ato infracional e, ao mesmo tempo, resguarda-lo dentro do sistema de proteção integral, pois sendo a aplicação da MSE uma sanção, ela pode produzir efeitos no jovem que a cumpre, devendo, por isso, carregar consigo, uma série de garantias instrumentais e materiais, que a tornem menos prejudicial ao desenvolvimento do jovem. Nos dizeres de FERRAJOLI, tais garantias e limites, mais do que indicar a punição devida à conduta infracional, busca limitar a punição do Estado, mitigando seus poderes e vinculando-o:

Tenha-se em conta de que aqui não se trata de uma condição suficiente, na presença da qual esteja permitido ou obrigatório punir, mas sim de uma condição necessária, na ausência da qual

\footnotetext{
203 KONZEN, Afonso Armando. Pertinência Socioeducativa. Reflexões sobre a natureza jurídica das medidas. Porto Alegre: Livraria do Advogado Ed., 2005. p. 63.

${ }^{204}$ KONZEN, Afonso Armando. Pertinência Socioeducativa. Reflexões sobre a natureza jurídica das medidas. Porto Alegre: Livraria do Advogado Ed., 2005. p. 63.

${ }^{205}$ FRAGOSO, Heleno Cláudio. In: Lições de direito penal - a nova parte especial. Rio de Janeiro, Forense, $11^{\text {a }}$ Ed., 1987, p. 1-2.
} 
não está permitido ou está proibido punir [...] A função específica das garantias do direito penal [...] na realidade não é tanto permitir ou legitimar, senão muito mais condicionar ou vincular e, portanto, deslegitimar o exercício absoluto da potestade punitiva. Precisamente porque 'delito', 'lei', 'necessidade', ofensa', 'ação' e 'culpabilidade' designam requisitos ou condições penais, enquanto 'juízo', 'acusação', 'prova' e 'defesa' designam condições processuais, os princípios que se exigem aos primeiros chamar-se-ão garantias penais, e os exigidos para os segundos, garantias processuais. ${ }^{206}$

De igual entendimento são as afirmações de TERRA, pois ao considerar as garantias instrumentais e materiais previstas na aplicação da MSE, enquanto garantias individuais asseguradoras do direito de liberdade, demonstra o quanto estas estabelecem limites do Estado, em seu proceder, na persecução penal.

Num enfoque do ponto de vista individual de todo cidadão menor de dezoito anos, trata-se de garantia asseguradora, em última análise, do direito de liberdade. É, em verdade, uma explicitação do alcance que tem o direito de liberdade em relação aos menores de dezoito anos. Exerce uma típica função de defesa contra o estado, que fica proibido de proceder a persecução penal.

Trata-se, portanto, de garantia individual, com caráter de fundamentabilidade, pois diretamente ligada ao exercício do direito de liberdade de todo cidadão menor de dezoito anos. $\mathrm{E}$ não se pode olvidar que a liberdade sempre está vinculada ao princípio fundamental da dignidade da pessoa humana, especialmente em relação às crianças e adolescentes, pois foram reconhecidos como merecedores de absoluta prioridade da atenção da família, da sociedade e do Estado, em face da peculiar condição de seres humanos em desenvolvimento. ${ }^{207}$

Quando analisamos o significado material da MSE, ou seja, o seu "ser", devemos ter em mente os efeitos que ela produz; já que estes são de ordem penal e sancionatória, resultando para o jovem a mesma reprimenda comportamental que o adulto vislumbra. Deste modo, a sanção penal do adulto e a MSE se equivalem, exercendo a mesma função social.

Em sendo sujeito, nunca mais poderá ou deverá ser visto como sujeito da tutela discricionária e subjetiva do Estado-juiz, mas sujeito da sua condição peculiar de pessoa em desenvolvimento,

\footnotetext{
${ }^{206}$ FERRAJOLI, Luigi. Direito e Razão: teoria do Garantismo Penal. São Paulo: Revista dos Tribunais, 2002. p. 74.

${ }^{207}$ TERRA, Eugênio Couto. “A idade penal mínima como cláusula pétrea”. In: A razão da idade: mitos e verdades. $1^{\text {a }}$ Edição. Coleção Garantias de Direitos. Série Subsídios Tomo VII. Brasília: MJ/SEDH/DCA, 2001. p. 60-61.
} 
com a incidência do instrumental garantista em defesa de uma determinação potencialmente subjetiva e discricionária. ${ }^{208}$

Distinguem-se, entretanto, em relação ao seu sentido instrumental, ou seja, seu "dever-ser", sua finalidade ${ }^{209}$. Com relação à aplicação da MSE, o critério para escolha da melhor medida não se assemelha ao critério da pena criminal, pois não se relaciona com a culpa e sim com os resultados pretendidos com esta aplicação de MSE, isto porque prevalece a instrumentalidade da pena e não sua retributividade.

Daí que este valor-orientador da diversidade da sanção há de ser um aspecto educativo, que deve marcar a medida que se aplica ao autor do fato penal típico, tornando-a mista, sob certo ângulo, na operação concreta do 'sopesar de valores conflitantes', entre os interesses do adolescente autor do fato penal típico, de um lado, e da sociedade, de outro. ${ }^{210}$

É inegável a importância do potencial instrumentalizador de mudanças da MSE, tanto que o seu tempo de cumprimento está diretamente relacionado ao seu resultado e à sua ação pedagógica, afinal, ela pretende a

prevenção da recidiva e a reinserção social pela prática de técnicas pedagógicas, confrontando o adolescente a sua responsabilidade. [...] A finalidade da medida socioeducativa pauta-se pela necessidade pedagógica do adolescente.

\section{$[\ldots]$}

A finalidade da medida socioeducativa consiste em abrir espaços para a obrigatória incidência de práticas pedagógicas. A medida é o espaço instrumental não só para a prevenção da delinquência, em resposta ao justo anseio de paz social, mas também para a inserção familiar e comunitária do jovem infrator. $^{211}$

Vemos que apesar da substância da MSE ser penal, sua finalidade é pedagógica. Pode-se, assim, considerar o principal destinatário desta instrumentalidade da MSE tanto o executor quanto o aplicador, vinculados aos seus critérios, princípios e garantias e finalidades, quais sejam: a capacidade de responder à sociedade e sua defesa,

\footnotetext{
${ }^{208}$ KONZEN, Afonso Armando. Pertinência Socioeducativa. Reflexões sobre a natureza jurídica das medidas. Porto Alegre: Livraria do Advogado Ed., 2005. p. 64.

${ }^{209} \mathrm{O}$ estudo da finalidade da pena apresenta-se por meio de diversas teorias que buscam discutir o seu caráter, punitivo, retributivo, ou reparador; e teorias de justificação que concebem efeitos e finalidades da pena.

${ }^{210}$ MACHADO, Martha de Toledo. A proteção constitucional de crianças e adolescentes e os direitos humanos. São Paulo: Manole, 2003. p. 241.

${ }^{211}$ KONZEN, Afonso Armando. Pertinência Socioeducativa. Reflexões sobre a natureza jurídica das medidas. Porto Alegre: Livraria do Advogado Ed., 2005. p. 77 e 89.
} 
bem como de interferir no desenvolvimento do jovem em conflito com a lei, o integrando, e o resignificando.

Assim, "a autoridade judiciária deve levar em conta obrigatoriamente as necessidades pedagógicas, preferindo aquelas que visem ao fortalecimento dos vínculos familiares e comunitários". ${ }^{212}$ A MSE visa dar conta das necessidades pedagógicas do adolescente, tanto que a autoridade judiciária deve "conformar o autor do ato infracional com aquela consequência capaz de responder adequadamente às necessidades pedagógicas reveladas pela infração e pelo estudo das condições pessoais do infrator."

Devem ser criados e desenvolvidos programas de atendimento que em sua metodologia educacional visem a inserção social e familiar do jovem em conflito com a lei.

A finalidade da medida socioeducativa, porque comprometida com a realização do interesse público na reinserção familiar e social do autor de ato infracional, deve visar, pela adesão do adolescente, a convivências pedagógicas, à superação das causas e consequências da infração, não só pelo aprender a conhecer e a fazer, mas também pelo aprender a ser e a conviver. Por isso, a execução da medida socioeducativa somente tem justificativa se comprometida com a realização do seu ideal pedagógico. ${ }^{213}$

Pensando em uma perspectiva freireana - na qual o ser humano está em constante transformação, podendo sempre "ser mais" -, o jovem é capaz de desenvolver as suas competências pessoais, relacionais, produtivas e cognitivas, a partir de modelos de aprendizagem. Neste sentido, cabe recuperar uma importante questão colocada por KONZEN: "Como educar para o viver em liberdade em ambientes de restrição ou de privação da liberdade?"214

A resposta pode ser dada a partir dos modelos e métodos pedagógicos ${ }^{215}$ a serem utilizados na aplicação da MSE.

\footnotetext{
212 KONZEN, Afonso Armando. Pertinência Socioeducativa. Reflexões sobre a natureza jurídica das medidas. Porto Alegre: Livraria do Advogado Ed., 2005. p. 79.

${ }^{213}$ KONZEN, Afonso Armando. Pertinência Socioeducativa. Reflexões sobre a natureza jurídica das medidas. Porto Alegre: Livraria do Advogado Ed., 2005. p. 136.

${ }^{214}$ KONZEN, Afonso Armando. Pertinência Socioeducativa. Reflexões sobre a natureza jurídica das medidas. Porto Alegre: Livraria do Advogado Ed., 2005. p. 81.

215 "Pedagógico é o respeitante à pedagogia. E a pedagogia pode ser entendida como um conjunto de doutrinas, princípios e métodos de educação e instrução que tendem a um objetivo prático. Pedagogia é a arte de educar, um conjunto de métodos e técnicas em busca do desenvolvimento pessoal e social. Cabe ao pedagogo a tarefa de combinar a ação educativa em favor do desenvolvimento do conhecimento, habilidades, valores e atitudes do educando." (KONZEN, Afonso Armando. Pertinência Socioeducativa. Reflexões sobre a natureza jurídica das medidas. Porto Alegre: Livraria do Advogado Ed., 2005. p. 80.)
} 
A busca de uma pedagogia especificamente destinada ao adolescente autor de ato infracional constitui-se em desafio permanente dos operadores do sistema de atendimento proposto pelo Estatuto da Criança e do Adolescente, operadores responsáveis pela execução das medidas. Boas contribuições podem ser encontradas em clássicos da pedagogia, cujos princípios incidem integralmente na pedagogia socioeducativa, como os métodos defendidos por Paulo Freire $[\ldots]^{216}$.

O projeto político-pedagógico a ser utilizado na aplicação das MSEs exige, portanto, uma atuação junto aos adolescentes no sentido de fazê-los experimentar respostas e construir novas alternativas, devendo estimular a flexibilidade, valorizar o vivencial, respeitar o diferente.

\section{b. Tipos de medidas socioeducativas}

$\mathrm{O}$ artigo 112 do Estatuto da Criança e do Adolescente elenca as medidas socioeducativas como a advertência, a obrigação de reparar o dano, a prestação de serviços à comunidade, a liberdade assistida, a inserção em regime de semiliberdade, a internação em estabelecimento educacional;e qualquer uma das previstas no Art. 101, I a $\mathrm{VI}^{217}$.

As seções VI e VII são as que tratam mais especificamente da medida de internação, possível tanto em regime de semiliberdade como de internação total. A imposição destas medidas tem como pressuposto a existência de provas da autoria e da materialidade da infração, tal qual ocorre no direito penal.

O regime de Semiliberdade é aquele no qual o adolescente irá se preparar para cumprir sua pena em meio aberto; é considerado um regime de transição, pois possibilita a realização de atividades externas.

Seção VI - Do Regime de Semiliberdade

Art. 120. O regime de semiliberdade pode ser determinado desde o início, ou como forma de transição para o meio aberto,

\footnotetext{
${ }^{216}$ KONZEN, Afonso Armando. Pertinência Socioeducativa. Reflexões sobre a natureza jurídica das medidas. Porto Alegre: Livraria do Advogado Ed., 2005. p. 81.

${ }^{217}$ Com relação a isto existe um forte crítica da doutrina, de que ao inserir nas medidas socioeducativas as medidas protetivas, volta-se à antiga doutrina da situação irregular, que não separa punição de proteção. Sendo tal inciso considerado por muitos como inconstitucional. Tal é o posicionamento de MACHADO, para quem "[...] o inciso VII do artigo 112 do ECA é inconstitucional, por permitir que medidas vagas sejam impostas pelo Estado como sanção pela prática de fato definido na lei penal como crime. Ou, ao menos, seria inconstitucional essa interpretação do dispositivo." MACHADO, Martha de Toledo. A proteção constitucional de crianças e adolescentes e os direitos humanos. São Paulo: Manole, 2003.p. 227.
} 
possibilitada a realização de atividades externas, independentemente de autorização judicial.

$\S 1^{\circ}$ São obrigatórias a escolarização e a profissionalização, devendo, sempre que possível, ser utilizados os recursos existentes na comunidade.

$\S 2^{\circ}$ A medida não comporta prazo determinado aplicando-se, no que couber, as disposições relativas à internação.

Como definida no artigo 120, a semiliberdade também é considerada uma medida privativa de liberdade. MACHADO que sustenta semelhante posição, afirma que independentemente da precária conceituação da medida na lei, ela se assemelha ao "regime aberto" da lei de execução penal.

Digo que ela é privativa de liberdade porque no aspecto de constrição de liberdade assemelha-se bastante ao 'regime aberto' da pena criminal privativa de liberdade. Mas o ECA não reconhece expressamente que a semiliberdade é sanção privativa de liberdade, o que leva alguns a classificá-la como uma medida meramente restritiva de liberdade. ${ }^{218}$

Por sua vez a internação é a medida privativa de liberdade sujeita aos princípios de brevidade, de excepcionalidade e de respeito à condição peculiar do adolescente em conflito com a lei como pessoa em desenvolvimento.

Seção VII - Da Internação

Art. 121. A internação constitui medida privativa da liberdade, sujeita aos princípios de brevidade, excepcionalidade e respeito à condição peculiar de pessoa em desenvolvimento.

Neste modelo de regime é permitida a realização de atividades externas (salvo expressa determinação judicial em contrário). A medida de internação também não comporta prazo determinado, devendo, a cada seis meses, ser reavaliada a sua manutenção.

O prazo máximo cominado em lei é de três anos, em relação a todas essas três sanções. Em relação à internação e à semiliberdade por norma expressa: artigo $121, \S 3^{\circ}$, quanto à primeira, e esse dispositivo combinado ao parágrafo $2^{\circ}$ do artigo 120, quanto à segunda. Já em relação à liberdade assistida, por aplicação analógica do mesmo dispositivo, já que não há norma específica e a CF, por força da reserva legal, impede a existência de pena completamente indeterminada, para considerar o mínimo do conteúdo da reserva legal, e a sanção

\footnotetext{
${ }^{218}$ MACHADO, Martha de Toledo. A proteção constitucional de crianças e adolescentes e os direitos humanos. São Paulo: Manole, 2003. p. 358.
} 
socioeducativa não deixa de contemplar, em boa medida, esse caráter de pena como já abordado. ${ }^{219}$

Importante frisar que este tipo de medida socioeducativa não poderá em nenhuma hipótese ultrapassar o período de três anos, caso este limite seja atingido, o adolescente será ser liberado e colocado em regime de semiliberdade ou de liberdade assistida.

No sistema do ECA, a internação, a semiliberdade e a liberdade assistida não 'comportam prazo determinado', no sentido de que o tempo de duração delas não é condicionada pela imposição da sentença, nem quanto a limite temporal mínimo, nem quanto ao máximo. Quanto às duas primeiras, a lei expressamente assim o reconhece, como se vê dos artigos $121, \S 2^{\circ}$, e $120, \S 2^{\circ}$; quanto à liberdade assistida, assim também decorre, na medida em que embora o parágrafo $2^{\circ}$ do artigo 118 mencione o 'prazo mínimo' de seis meses, em seguida esclarece que este pode ser prorrogado, sem indicação de quaisquer parâmetros para tal prorrogação. ${ }^{220}$

O artigo 121, e §§s do ECA que dispõe sobre a possibilidade de realização destas atividades $\left(\S 1^{\circ}\right)$; o fato de a medida não comportar prazo determinado, devendo sua manutenção ser reavaliada a cada seis meses $\left(\S 2^{\circ}\right)$; a impossibilidade de a internação exceder três anos $\left(\S 3^{\circ}\right)$; e a liberação compulsória aos vinte e um anos de idade $\left(\S 5^{\circ}\right)$. A internação somente deverá ser aplicada em casos extremos tal como disposto pelo art. 122 do ECA:

Art. 122. A medida de internação só poderá ser aplicada quando:

I - tratar-se de ato infracional cometido mediante grave ameaça ou violência a pessoa;

II - por reiteração no cometimento de outras infrações graves;

III - por descumprimento reiterado e injustificável da medida anteriormente imposta.

$\S 1^{0}$ O prazo de internação na hipótese do inciso III deste artigo não poderá ser superior a 3 (três) meses, devendo ser decretada judicialmente após o devido processo legal.

$\S 2^{\circ}$. Em nenhuma hipótese será aplicada a internação, havendo outra medida adequada.

\footnotetext{
${ }^{219}$ MACHADO, Martha de Toledo. A proteção constitucional de crianças e adolescentes e os direitos humanos. São Paulo: Manole, 2003. p. 353.

${ }^{220}$ MACHADO, Martha de Toledo. A proteção constitucional de crianças e adolescentes e os direitos humanos. São Paulo: Manole, 2003. p. 352.
} 
A internação deve ocorrer em local específico, exclusivo para adolescentes, devendo ser uma preocupação do estabelecimento a separação por critérios de idade, a gravidade da infração, entre outras peculiaridades dos adolescentes.

Os artigos 123 e 124 dispõem sobre as condições de internação e os direitos do adolescente em conflito com a lei em privação de liberdade:

Art. 23. A falta ou a carência de recursos materiais não constitui motivo suficiente para a perda ou a suspensão do pátrio poder poder familiar. (Expressão substituída pela Lei $\mathrm{n}^{\circ} 12.010$, de 2009) Vigência

Parágrafo único. Não existindo outro motivo que por si só autorize a decretação da medida, a criança ou o adolescente será mantido em sua família de origem, a qual deverá obrigatoriamente ser incluída em programas oficiais de auxílio.

Art. 24. A perda e a suspensão do poder familiar serão decretadas judicialmente, em procedimento contraditório, nos casos previstos na legislação civil, bem como na hipótese de descumprimento injustificado dos deveres e obrigações a que alude 0 art. 22

No que toca à garantia dos demais direitos do adolescente privado de liberdade, deve-se observar o parágrafo único do artigo 123 que diz, expressamente, que durante o período de internação, inclusive provisória, "serão obrigatórias atividades pedagógicas", de modo que a especificidade da privação de liberdade "não se restringe aos direitos-garantias de brevidade e excepcionalidade dela, mas diz respeito também à própria 'essência' da medida privativa de liberdade; a redação dada ao dispositivo constitucional, que une o comendo final aos dois primeiros pela conjunção aditiva, somente pode significar que a privação da liberdade, em si mesma, há de ter uma marca distintiva em relação àquela aplicada aos adultos".221

Tendo por base a especificidade da privação de liberdade dos adolescentes em conflito com a lei, passaremos a analisar a sua eficácia, já que destinada a seres em desenvolvimento e beneficiários de todo um sistema especial de proteção e prioridade.

\footnotetext{
${ }^{221}$ MACHADO, Martha de Toledo. A proteção constitucional de crianças e adolescentes e os direitos humanos. São Paulo: Manole, 2003. p. 242-243.
} 


\section{c. A eficácia das medidas socioeducativas}

Muito se discute sobre a eficácia das medidas socioeducativas, principalmente no que se refere a privação de liberdade. A pesquisadora VICENTIN ${ }^{222}$ ao realizar um estudo sobre o histórico de resistência empreendida pelos jovens internos da Febem-SP, tratando das rebeliões da pobreza verificou a repetição da frase "não nasci para semente", que demonstrando a situação-limite em que vive o adolescente em conflito com a lei e a infração enquanto uma "recusa de reconhecimento simbólico desses jovens, ante o desprezo e indiferença a que estão submetidos (mais acentuadas ainda ante as desigualdades sociais do cenário brasileiro)" sendo realizado um deslocamento do adolescente para a busca por reconhecimento e autonomia ${ }^{223}$.

De igual posicionamento o estudo realizado por VIOLANTE, para quem o "modo marginal de sobrevivência" do adolescente em conflito com a lei são construídos ideologicamente de forma a significar e "dissimular as reais relações de força no modo de produção capitalista", tais comportamentos são "manifestações e não causa de sua condição de vida marginal”, conforme transcrevemos:

São manifestações de revolta, de insubmissão às condições de vida que lhe são socialmente impostas. Não podem ser considerados comportamentos revolucionários porque se dão ao nível individual, competitivo, de modo desorganizado, demonstrando o limite possível da consciência desses indivíduos e a presença de crenças e valores dominantes. Não são, por isso, comportamentos transformadores de sua condição de vida, senão mantenedores. Não são a causa da desordem social, mas se constituem na sua denúncia. ${ }^{24}$

Estudos mostram que o ato infracional deriva de uma busca por inclusão e reconhecimento, ou seja, dentro do dilema do decente malandro, no qual o "ser decente" significa ser aceito socialmente, mas marcado uma vez que acomodado dentro de suas

\footnotetext{
${ }^{222}$ VICENTIN, Maria Cristina G.onçalves. A vida em Rebelião. Jovens em conflito com a Lei. São Paulo: Hucitec: Fapesp, 2005. p. 210.

${ }^{223}$ Em seu estudo, VICENTIN recorre a Carmen de Oliveira, que enfatiza no ato infracional "sua dimensão de resposta à omissão social em um país de 'direitos virtuais'. Ele configura-se como recusa recíproca de integração: a marginalização que a sociedade dirige à juventude de periferia se faz acompanhar de recusa destes jovens aos parâmetros socialmente aceitos. O delito expressaria, então, essa 'zona de vazio para a participação na vida pública', onde os adolescentes são 'fortemente convocados ao palco principal do cenário contemporâneo', mas 'sem usufruir as prerrogativas da cidadania'(OLIVEIRA, Carmen de. Sobrevivendo no inferno. A violência juvenil contemporânea. Porto Alegre: Sulina, 2001, p. 99; apud VICENTIN, Maria Cristina Gonçalves. A vida em Rebelião. Jovens em conflito com a Lei. São Paulo: Hucitec: Fapesp, 2005. p. 200.)

${ }^{224}$ VIOLANTE, Maria Lucia. O dilema do decente malandro. São Paulo: Cortez - Autores Associados, 1982, p. 186. apud VICENTIN, Maria Cristina Gonçalves. A vida em Rebelião. Jovens em conflito com a Lei. São Paulo: Hucitec: Fapesp, 2005. p. 200.)
} 
condições marginais de sobrevivência; "ser malandro" significa ser respeitado pelo grupo, em razão de sua insubmissão às suas condições de existência.

Pesquisa de doutorado em serviço social realizada por GUARÁ nos mostra que a situação de exclusão social de grande parcela dos jovens em conflito com a lei, são conformadas por elementos históricos, culturais e sociais, sendo responsáveis pelas contradições e instabilidades (pessoal, social e moral) destes indivíduos. Isto é, estes adolescentes não vivenciam situações que promovam seu desenvolvimento, o qual já é prejudicado em virtude das condições sociais que estes se encontram ${ }^{225}$.

Assim, se a MSE institucionaliza o adolescente, privando-o de desenvolver interseções com o mundo exterior, este pode acabar criando mecanismos de resistência para cumprir a MSE sem vivenciá-la em seu caráter pedagógico; estabelecendo laços que o mantêm em "relação de subordinação e de dependência pelo resto da Vida". 226

Nas palavras de RASSIAL, um dos desafios da MSE é pensar como mobilizar os jovens em conflito com a lei à uma "rebeldia ativa e como gerenciar novas formas de lidar com a liberdade que não seja o modelo 'fora-da-lei'.,"227 Desafio que pode ser viabilizado através da ação pedagógica, a qual também pode auxiliar a minimizar para o jovem, o "grau de angústia e de sofrimento decorrente da perda ou da restrição da liberdade." 228

\section{2. $O$ sistema de cumprimento de medidas socioeducativas.}

No presente trabalho como trataremos da educação em estabelecimentos de privação de liberdade, manteremos nossas atenções à medida de internação que retira o adolescente em conflito com a lei do convívio com a sociedade, visando sua posterior reinserção ao meio familiar e comunitário, bem como o seu aprimoramento profissional e intelectivo.

$\mathrm{O}$ atendimento à criança e ao adolescente no Brasil mudou com o advento do Estatuto da Criança e do Adolescente, que trouxe a Doutrina da Proteção Integral, no lugar da Doutrina da Situação Irregular, que não reconhecia direitos às crianças e adolescentes.

${ }^{225}$ GUARÁ, Isa M. F. da Rosa (2000). "O crime não compensa, mas não admite falhas: padrões morais de jovens autores de infração". Doutorado em Serviço Social. São Paulo: PUC-SP. p. 224.

${ }^{226}$ SILVA, Roberto da. Os filhos do governo. A formação da identidade criminosa em crianças órfãs e abandonadas. São Paulo: Ática, 1997, p. 173.

${ }^{227}$ RASSIAL, apud OLIVEIRA, Carmen Silveira de. Sobrevivendo no inferno. A violência juvenil contemporânea. Porto Alegre: Sulina, 2001, p. 100.

${ }^{228}$ KONZEN, Afonso Armando. Pertinência Socioeducativa. Reflexões sobre a natureza jurídica das medidas. Porto Alegre: Livraria do Advogado Ed., 2005. p. 92. 
Conforme já mencionado, apesar de o ECA possuir um sistema de execução de MSEs, ele preocupou-se apenas elencar as medidas e as garantias com relação aos adolescentes em conflito com a lei, mas não em esmiuçar a correspondência entre o crime/delito praticado e a medida a ser imposta. No sistema do ECA o sistema trifásico e a dosimetria da pena não são aplicados, não havendo delimitação legal quanto à sanção imposta, à sua duração, e ao cumprimento.

O juiz deve simplesmente fixar qual sanção incide no caso concreto, escolhendo, por exemplo, entre a liberdade assistida, a semiliberdade ou a internação. Mas a lei não impõe que ele concretize, delimite na sentença, a duração da sanção escolhida. Ao contrário, a lei estabelece que esta sanção 'não comporta prazo determinado'.

Mas, em atenção aos comandos constitucionais da brevidade noção que, em alguma medida, veio especificada na lei ordinária - e de determinabilidade da sanção ínsitos na reserva legal, o que a lei faz é impor o prazo máximo de duração de cada sanção cominada e impor a reavaliação da necessidade de manutenção da sanção periodicamente. ${ }^{229}$

Com a criação do SINASE, o cumprimento da MSE passou a ser mais delimitado. Entretanto, ainda são diversas as lacunas quanto ao fornecimento educacional na privação de liberdade e ao acompanhamento do adolescente.

\section{e. O espaço prisional destinado ao cumprimento de medidas socioeducativas de internação}

Como o escopo de nossa pesquisa se restringe ao trato do direito fundamental à educação dos adolescentes que se encontram em privação de liberdade, nossa preocupação é esmiuçar as medidas socioeducativas de semiliberdade e de internação, bem como os espaços de cumprimento destas.

A função ordenadora do Direito a partir do preceito 'dar a cada um o que lhe é de devido' exige, para observância do ordenamento jurídico do Estado Democrático de Direito e do interesse social, que o desvio e a infração sejam sancionados. Porém como a adolescência é um período na vida do indivíduo, no qual ele ainda está formando sua personalidade, com possibilidade de autotransformação do próprio comportamento, o legislador busca preservar o desenvolvimento adequado de sua

\footnotetext{
${ }^{229}$ MACHADO, Martha de Toledo. A proteção constitucional de crianças e adolescentes e os direitos humanos. São Paulo: Manole, 2003. p. 353.
} 
personalidade (cuja maior vulnerabilidade deve ser observada) e afastá-lo das consequências negativas da privação da liberdade, devendo a resposta estatal ao crime praticado por adolescente, ainda que contemple a privação de liberdade, ser excepcional e breve (direito à excepcionalidade e à brevidade da privação de liberdade).

A prisão, cadeia ou cárcere é o espaço institucional que simboliza o direito de punição do Estado. Esta teve diferentes utilizações desde que foi implantada no Brasil, servindo como alojamento de escravos e ex-escravos, abrigo para crianças e adolescentes abandonados e/ou infratores, abrigo para doentes mentais, local de encarceramento de inimigos políticos, infratores da lei penal, criminosos, contraventores.

Segundo PEDROSO:

A análise da dinâmica da existência do preso e das prisões está diretamente ligada à constituição do poder de Estado. O criminoso ameaça as instituições legais com seu comportamento anormal, infringindo regras estabelecidas para o bom ordenamento social, tendo no castigo a sua forma de punição. $O$ Estado utiliza suas atribuições penais para circunscrever, ou melhor, "desterritorializar" o criminoso do convívio dos demais. O espaço da prisão é, por esta razão, construído para esse fim: um território novo, com regras novas. ${ }^{230}$

Em 1970, FOUCAULT já destacava que:

Publicam-se poucas informações sobre as prisões; é uma das regiões escondidas de nosso sistema social, uma das caixaspreta de nossa vida. Temos o direito de saber, nós queremos saber [...]. Propomo-nos a fazer saber o que é uma prisão: quem entra nela, como e por que se vai parar nela, o que se passa ali, o que é a vida dos prisioneiros e, igualmente, a do pessoal de vigilância, o que são os prédios, a alimentação, a higiene, como funcionam o regulamento interno, o controle médico, os ateliês; como se sai dela e o que é, em nossa sociedade, ser um daqueles que dela saiu. ${ }^{231}$

Com o encarceramento, espera-se a punição e a reeducação do infrator simultaneamente à proteção da sociedade, dentro da ideia de aprisionamento enquanto prevenção. Em que pese a medida socioeducativa prevista no ECA e no SINASE ter caráter educativo e não punitivo, o que poria por chão a ideia da "prevenção social",

\footnotetext{
${ }^{230}$ PEDROSO, Regina Célia. Os signos da Opressão. História e Violência nas prisões brasileiras. Coleção Teses e Monografias vol. 05. Arquivo do Estado Imprensa Oficial do Estado - São Paulo, 2003.

${ }^{231}$ FOUCAULT, Michel. Vigiar e punir: nascimento da prisão. História da violência nas prisões. $35^{\mathrm{a}}$. edição, tradução de Raquel Ramalhete. Petrópolis, RJ: Vozes, 2008. p. 2.
} 
vemos na aplicação da MSE a forte relação entre o tempo de encarceramento do jovem e a gravidade da infração por ele cometida. Para SÁ:

Ao ser atingido em sua liberdade, pela condenação, o sentenciado está sendo privado de certa quantidade de um definido bem jurídico, a liberdade, correspondente a dias, meses ou anos de prisão. O tempo de privação de liberdade ou estada na prisão é proporcional ao mal produzido pela ação ou omissão criminosa. $^{232}$

Analisando a privação de liberdade a partir da prisão e sua evolução ao longo da história, vemos que o sistema punitivo-repressivo sofreu diversas modificações a partir do século XVIII. As práticas de tratamento do réu como a condenação à morte na fogueira e os castigos físicos foram substituídos pela pena privativa de liberdade, surgindo ai o esboço do sistema penitenciário tal como o conhecemos atualmente.

No Brasil, a pena da prisão foi regulamentada pela Constituição do Império do Brasil de 1824, sofrendo o acréscimo de diversas leis, decretos e códigos. Sob forte influência europeia, a Constituição de 1824 regulamentou os direitos do encarcerado trazendo alterações referentes às práticas punitivas e às discussões sobre penalogia brasileira.

As principais mudanças ocorridas no sistema prisional brasileiro se referem ao direito reservado para a defesa do acusado, à conduta policial relativa ao aprisionamento do réu e aos direitos elementares que impediriam, ao menos teoricamente, os excessos da lei. Interessante notar que mesmo com estas mudanças, cujo objetivo era reduzir os excessos das penas, o Código Criminal promulgado em 1830 possuía a pena de morte entre suas penalidades corporais, sendo esta abolida somente pelo Código Penal de 1890.

Com o passar dos anos, a pena restritiva de liberdade tornou-se a regra geral, sendo, primeiro, forma de punição, e, posteriormente, forma de regeneração do indivíduo condenado pela Lei. O universo carcerário, igualmente, passou por diversas formas de punição aplicadas a diversos tipos de crimes e contravenções todas com justificativas adequadas a interesses políticos e sociais.

PEDROSO é enfática ao afirmar a existência da institucionalização de mecanismos repressivos:

${ }^{232}$ SÁ, Geraldo Ribeiro de. A prisão dos Excluídos. Origens e Reflexões sobre a Pena Privativa de Liberdade. Rio de Janeiro: Diadorim Editora Ltda.,1996. p. 111. 
A institucionalização de mecanismos repressivos sobre as camadas excluídas também é de longa data no Brasil. Prisões arbitrárias, torturas, raptos, maus tratos, descasos, perseguições, ou simplesmente a opressão detectada na prisão, representavam nitidamente o poder do Estado sobre a população marginalizada. ${ }^{23}$

Cumpre transcrever rapidamente o histórico que ela faz da prisão no Brasil:

A primeira menção à prisão no Brasil é dada no Livro $\mathrm{V}$ das Ordenações Filipinas do Reino, que decreta a Colônia como presídio de degredados. A pena era aplicada aos alcoviteiros, culpados de ferimentos por arma de fogo, duelo, entrada violenta ou tentativa de entrada em casa alheia, resistência a ordens judiciais, falsificação de documentos e contrabando de pedras e metais preciosos.

A utilização do território colonial como local de cumprimento das penas se estende até 1808 , ano marcado por mudanças significativas rumo à autonomia legal e aos anseios de modernidade, tão em voga naqueles tempos.

A instalação da primeira prisão brasileira é mencionada na Carta Régia de 1769, que manda estabelecer uma casa de correção no Rio de Janeiro.

Segundo os rumos da jurisprudência em todo o mundo, a implantação de um sistema prisional se fazia necessária no Brasil. A assimilação da nova modalidade penal se fez pela Constituição de 1824, que estipulou as prisões adaptadas ao trabalho e separação dos réus: pelo Código Criminal de 1830, que regularizou a pena de trabalho e a de prisão simples e pelo Ato Adicional, de 12 de agosto de 1834, de importância fundamental, que deu às Assembleias Legislativas provinciais o direito sobre a construção de casas de prisão, trabalho, correção e seus respectivos regimes. ${ }^{234}$

Vemos que desde o estabelecimento da primeira prisão brasileira (uma casa de detenção), mencionada na Carta Magna de 1769, muitos anos se passaram para que se começasse a mencionar a necessidade de adaptações e da regularização do trabalho. A privação da liberdade com obrigação de trabalho foi recomendada como o melhor meio de reabilitação de criminosos, tanto que o Código Criminal do Império acolheu duas espécies de penas: a prisão simples e a prisão com trabalho, variando a duração de

\footnotetext{
${ }^{233}$ PEDROSO, Regina Célia. Os signos da Opressão. História e Violência nas prisões brasileiras. Coleção Teses e Monografias vol. 05. Arquivo do Estado Imprensa Oficial do Estado - São Paulo, 2003. p. 43.

${ }^{234}$ PEDROSO, Regina Célia. Os signos da Opressão. História e Violência nas prisões brasileiras. Coleção Teses e Monografias vol. 05. Arquivo do Estado Imprensa Oficial do Estado - São Paulo, 2003. p. 61
} 
ambas conforme a penalidade aplicada, desde a prisão perpétua até a reclusão de alguns dias. Isto porque, a prisão, sob uma visão utópica, tinha como suas principais metas:

Modificar a índole dos detidos através da recuperação dos prisioneiros; reduzir o crime, a pobreza e a insanidade social; dirigir suas finalidades para a cura e a prevenção do crime; e reforçar a segurança e a glória do Estado. ${ }^{235}$

Em que pese à existência de objetivos tão nobres, os órgãos públicos pouco se interessavam pela administração penitenciária, segundo estudos realizados por PEDROSO $^{236}$ que nos mostra que "[...] o mau gerenciamento foi uma das causas que desde a implantação dos cárceres em território brasileiro, impediu que os objetivos fossem atingidos, ou seja, o de transformar o condenado em uma "nova pessoa".

Com advento da República surgiu um novo estatuto regulador, a Constituição, a qual alterou o sistema de penalidades anteriormente estabelecido, abolindo as penas de morte, de desterro e de galés e adotando a prisão celular como base do novo regime político, mais condizente com os objetivos republicanos do governo. Ocorre que mesmo com estas modificações paradigmáticas das penas, os estabelecimentos prisionais ainda estão muito aquém dos objetivos da pena e do Estado Democrático de Direito que o Brasil se propõe a ser.

No final do século XIX e início do século XX já havia casas públicas de custódia para crianças e adolescentes. A criação da Funabem e das Febens estaduais, por volta da década de 1960, fez com que o Poder Público interferisse no acolhimento de crianças e adolescentes abandonados ou em conflito com a lei ${ }^{237}$, ampliando o atendimento e, consequentemente, a institucionalização de crianças e adolescentes carentes.

${ }^{235}$ PEDROSO, Regina Célia. Os signos da Opressão. História e Violência nas prisões brasileiras. Coleção Teses e Monografias vol. 05. Arquivo do Estado Imprensa Oficial do Estado - São Paulo, 2003. p. 74.

${ }^{236}$ PEDROSO, Regina Célia. Os signos da Opressão. História e Violência nas prisões brasileiras. Coleção Teses e Monografias vol. 05. Arquivo do Estado Imprensa Oficial do Estado - São Paulo, 2003. p. 74.

237 "É que o sistema jurídico anterior, pré-constituição de 1988, além de figurar crianças e adolescentes como objeto das relações jurídicas do cidadão pai-patrão, na expressão de Ferrajoli, e não como sujeito de direitos especiais em face do mundo adulto, orientava-se, simultaneamente, pela cisão entre duas categorias distintas de crianças e adolescentes: a infância normal (infância família, infância escola, infância protegida e fruindo os bens materiais e culturais socialmente produzidos) e a infância desviante (infância não família, não escola, infância desassistida, não fruindo desses bens, e fundida num conceito jurídico de carência-delinquência); ao primeiro grupo aplicava-se um conjunto de regras, o até chamado direito de família, e ao segundo outro conjunto de regras, o chamado direito do menor, que se apropriava de algumas noções daquele, mas que configurava um corpo próprio de normas e se aplicava exclusivamente ao segundo grupo." (MACHADO, Martha de Toledo. A proteção constitucional de crianças e adolescentes e os direitos humanos. São Paulo: Manole, 2003. p. 146) 
Analisando o sistema de atendimento a crianças e adolescentes, nos deparamos com um histórico de omissões estatais no que diz respeito à implantação de políticas públicas relacionadas aos internos e suas peculiaridades. As omissões foram tantas que relatório da ONU para a Tortura, feito por Nigel Rodley, em sua missão oficial ao Brasil no ano de 2000, revelou diversos casos de tortura e omissões relativas a direitos fundamentais principalmente no que se refere a estabelecimentos prisionais:

Como observou Nigel Rodley, relator especial da ONU sobre o tema tortura, em visita oficial ao Brasil, não é razoável tratar os adolescentes como animais, para posteriormente devolvê-los à sociedade com a pretensão de terem se tornado "pessoas reintegradas e civilizadas". Tal sistemática não constitui uma medida de combate à criminalidade, mas, ao revés, constitui medida de estímulo à criminalidade. ${ }^{238}$

O sistema penal juvenil representa uma instituição que não cumpre suas funções manifestas e se caracteriza totalizante e despersonalizadora, tornando a violência um instrumento de troca.

Apesar de a Constituição Federal impor ao Estado, responsável pela manutenção da unidade prisional, o dever de conferir aos internos condições mínimas de existência digna, e do ECA prever, expressamente, em seu artigo $125^{239}$ que é dever do Estado zelar pela integridade física e mental dos internos, este ainda se mostra omisso em muitas de suas necessidades fundamentais, sendo a dignidade apenas uma expectativa distante para a maioria deles.

Os jovens em conflito com a lei no Brasil são submetidos a uma condição de invisibilidade, que, ao mesmo tempo em que é sintomática, legitima e intensifica as marcas de desigualdades econômicas, raciais e de gênero aos quais diversas pessoas são submetidas na sociedade brasileira.

Para que se compreenda as razões desse permanente descumprimento das disposições legais, em especial, por parte das instituições responsáveis justamente por sua aplicação, deve-se ter em conta a cultura predominante no país de desrespeito à estrutura legal vigente, sobretudo quando ela se refere à atribuição de direitos a segmentos populacionais menos favorecidos. Fato que não deixa de representar uma contundente negativa do Estado brasileiro em reconhecer os direitos civis dessas

\footnotetext{
${ }^{238}$ PIOVESAN, Flávia. "A inconstitucionalidade da redução da maioridade penal". In: A razão da idade: mitos e verdades. $1^{a}$ Edição. Coleção Garantias de Direitos. Série Subsídios Tomo VII. Brasília: MJ/SEDH/DCA, 2001. p. 73-74.

${ }^{239}$ Art. 125. É dever do Estado zelar pela integridade física e mental dos internos, cabendo-lhe adotar as medidas adequadas de contenção e segurança.
} 
populações num fenômeno característico da organização social e política brasileira denominada, por CALDEIRA, ${ }^{240}$ democracia disjuntiva ${ }^{241}$.

A invisibilidade permanece mesmo com o crescente número de indivíduos que se encontram no sistema prisional. Conforme dados da Comissão Interamericana de Direitos Humanos, em 5 de setembro de 2000, o Centro pela Justiça e o Direito Internacional - CEJIL, apresentou à CIDH petição ${ }^{242}$ contra a República Federativa do Brasil na qual denunciou violação dos artigos 4, 5, 19, 8 e 25 da Convenção Americana no que toca ao direito à vida, à integridade física, à proteção especial à infância, às garantias judiciais e à recurso judicial, bem como a violação do artigo 13 do Protocolo de San Salvador, que versa sobre o direito à educação, em prejuízo dos adolescentes acusados de cometerem infrações penais, custodiados nas unidades da Fundação do Bem Estar do Menor (FEBEM), no Estado de São Paulo.

Dados que revelam o quão necessário se faz voltarmos nossa atenção à população jovem, principalmente com relação aqueles que se encontram em privação de liberdade, uma vez que o Estado brasileiro ainda não tem garantido condições adequadas para o cumprimento de pena de privação de liberdade nas instituições fechadas no país.

Concluímos que a questão prisional, problema político que é, exige que toda a sociedade civil se posicione, principalmente partidos políticos, imprensa, entidades religiosas, sindicatos e movimentos sociais.

\section{f. O sistema de cumprimento de medida socioeducativa de internação}

A lei $n^{\circ} .12 .594$, de 18 de janeiro de 2012, que institui o Sistema Nacional de Atendimento Socioeducativo (SINASE), possui conteúdo considerado garantista ${ }^{243}$; ela é a responsável pela regulamentação da execução das medidas destinadas a adolescentes que pratiquem ato infracional. Ele consagra o conjunto ordenado de princípios, regras e critérios que envolvem a execução de MSEs, os sistemas estaduais,

\footnotetext{
${ }^{240}$ CALDEIRA, Teresa P. do Rio. Cidade de Muros: Crime, Segregação e Cidadania em São Paulo. São Paulo: Editora 34/Edusp, 2000.

${ }^{241}$ Para Caldeira a expansão da cidadania política, através do processo de transição democrática, se desenvolveu junto com a deslegitimação da cidadania civil e a emergência de um espaço público fragmentado e segregado, por isso o caráter disjuntivo desse processo de democratização.

${ }^{242} \mathrm{http} / / / \mathrm{www} . c i d h . o a s . o r g / a n n u a l r e p / 2002$ port/brasil12328.htm - Acesso em 10.10.2012.

${ }^{243}$ Garantismo Penal - [...] Modelo normativo de direito que obedece a estrita legalidade, típico do Estado Democrático de Direito, voltado a minimizar a violência e maximizar a liberdade, impondo limites à função punitiva do Estado.[...] (NUCCI, Guilherme de Souza. Código Penal Comentado. São Paulo: Editora Revista dos Tribunais, 2008).
} 
distrital e municipais, bem como todos os planos, políticas e programas específicos de atendimento a adolescente em conflito com a lei.

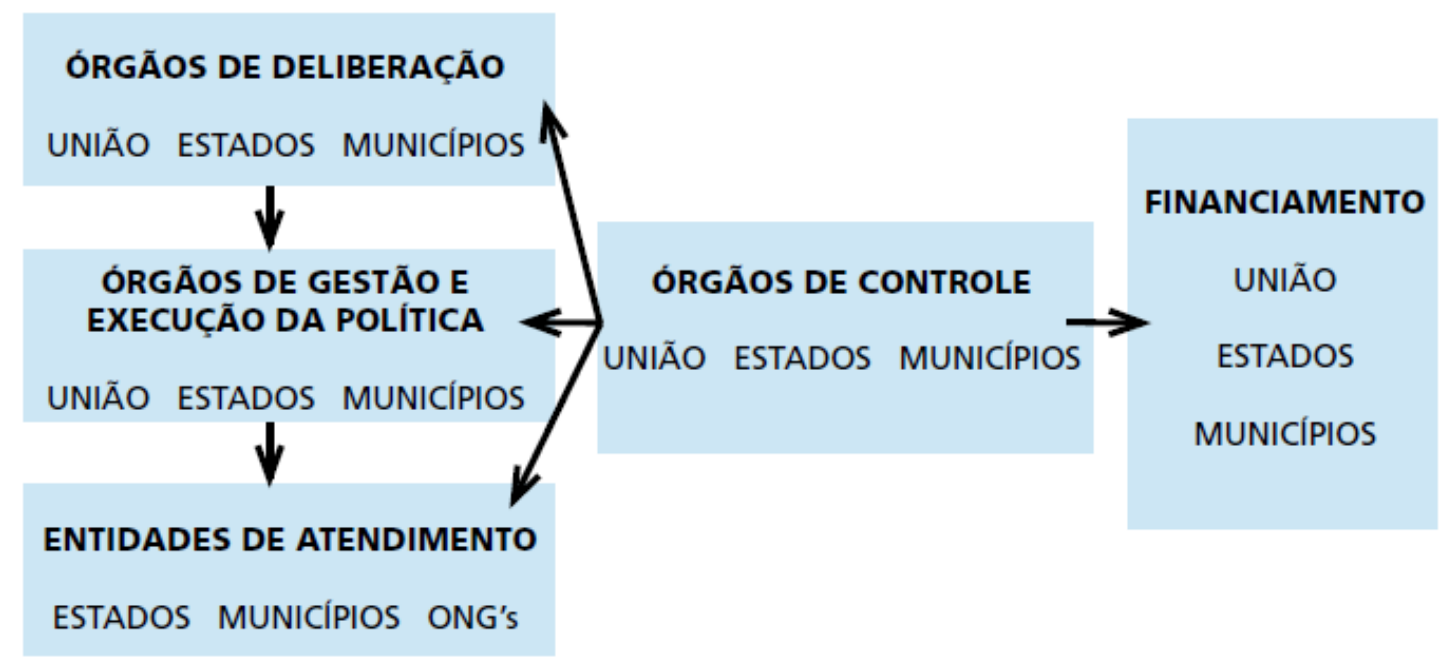

Fonte: SINASE/ Secretaria Especial dos Direitos Humanos - Brasília-DF: CONANDA, 2006.

O SINASE também elenca um extenso rol de direitos e consoantes com as principais recomendações internacionais na área. Dispondo sobre os direitos como saúde, educação, assistência social, exercício do trabalho e de atividades intelectuais, ele trata também da obrigação do Estado em oferecer condições materiais à execução desses direitos.

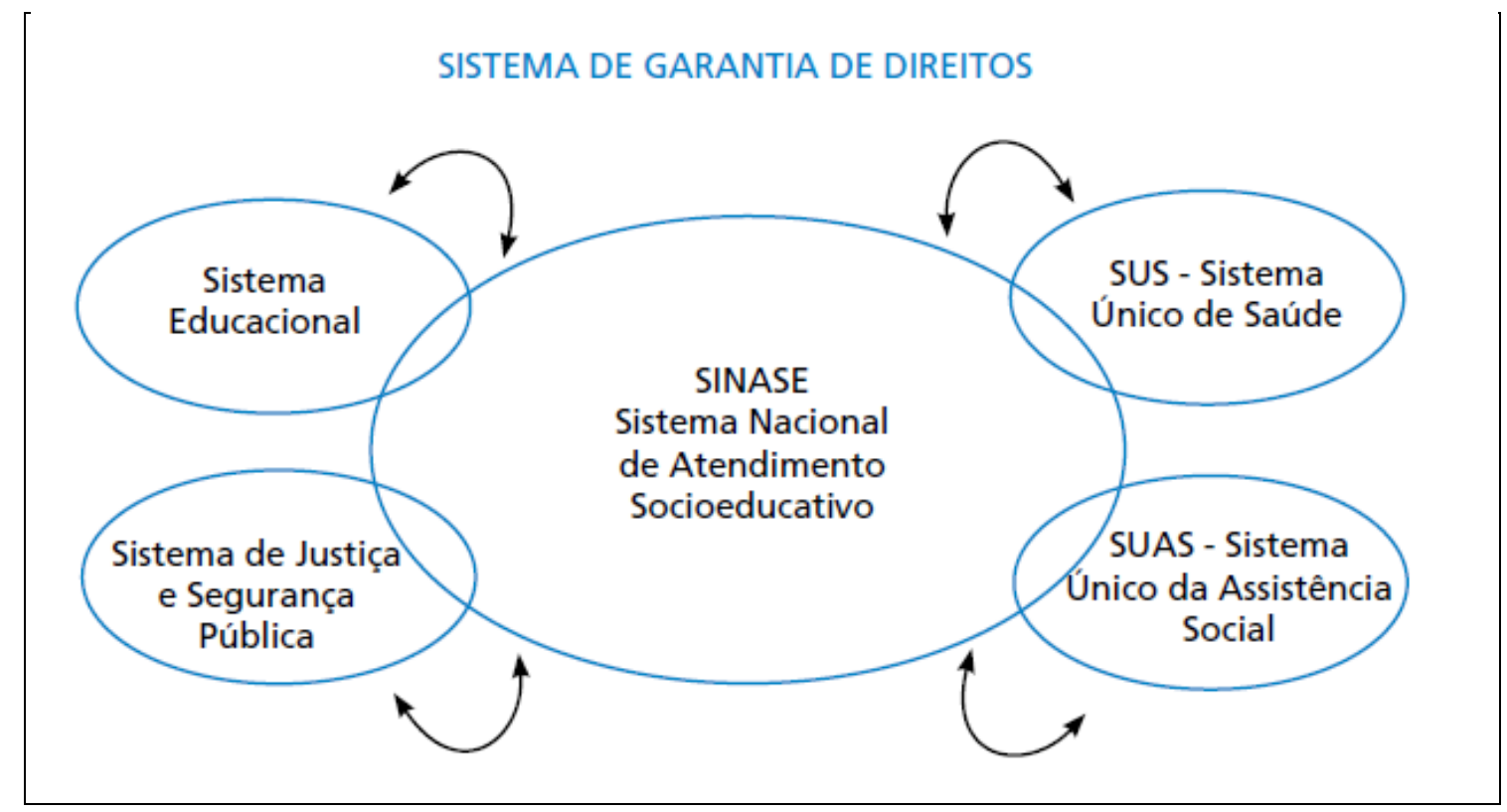

Fonte: SINASE/ Secretaria Especial dos Direitos Humanos - Brasília-DF: CONANDA, 2006.

Conforme já mencionamos, o cumprimento da medida, tal como disposto no art. 123 do ECA, será em entidade exclusiva para adolescentes, local distinto daquele 
destinado ao abrigo ${ }^{244}$, obedecida rigorosa separação por critérios de idade, compleição física e gravidade da infração. Sendo obrigatórias as atividades pedagógicas.

O sistema reafirma a diretriz do Estatuto sobre a natureza pedagógica da medida socioeducativa, assim, a execução das MSEs é regida por princípios como legalidade, excepcionalidade da intervenção judicial (preferência pela autocomposição de conflitos); prioridade a práticas restaurativas; proporcionalidade; brevidade da medida; individualização (conforme idade, capacidades e circunstâncias pessoais do jovem); fortalecimento dos vínculos familiares e comunitários no processo socioeducativo, entre outros.

A implementação do SINASE objetiva primordialmente o desenvolvimento de uma ação socioeducativa sustentada nos princípios dos direitos humanos. Defende, ainda, a ideia dos alinhamentos conceitual, estratégico e operacional, estruturada, principalmente, em bases éticas e pedagógicas. ${ }^{245}$

O processo socioeducativo é composto por instrumentos que se completam para auxiliarem a resignificação do adolescente em conflito com a lei.

O SINASE busca concretizar essa comunidade socioeducativa através da gestão participativa (com a participação de todos nas deliberações); realização de diagnóstico situacional dinâmico e permanente (da situação do programa de atendimento); realização de assembleias (com a participação dos adolescentes e das famílias - quando necessário); criação de comissões temáticas ou grupos de trabalho (buscando solucionar questões levantadas no diagnóstico); realização de avaliação participativa; criação de rede interna institucional (funcionamento articulado dos diferentes setores do programa); criação de rede externa (articulação com parceiros envolvidos na promoção do adolescente); existência de equipes técnicas multidisciplinares (agentes de diferentes áreas do conhecimento e especialidades);

\footnotetext{
244 Tão nítida essa clivagem básica que a lei buscou introduzir, e que está intimamente presa à estrita observância da reserva legal, que o sistema preocupou-se em dispor expressamente no parágrafo único do artigo 101 que o abrigo não pode consubstanciar privação de liberdade, expressão utilizada na sua acepção estrita de cárcere, de prisão, eis que senão restaria o dispositivo desprovido de qualquer conteúdo e a lei, como é basilar, não contém expressões ou disposições inúteis." (MACHADO, Martha de Toledo. A proteção constitucional de crianças e adolescentes e os direitos humanos. São Paulo: Manole, 2003. p. 212-213)

${ }^{245}$ Sistema Nacional de Atendimento Socioeducativo - SINASE/ Secretaria Especial dos Direitos Humanos - Brasília-DF: CONANDA, 2006.p. 16.
} 
criação de um projeto pedagógico e de uma rotina da unidade e/ou programa de atendimento $^{246}$.

Assim, a ação socioeducativa deverá respeitar as fases de desenvolvimento do adolescente - considerando suas potencialidades, sua subjetividade, suas capacidades e suas limitações - buscando garantir a particularização de seu acompanhamento. Para isto será criado o Plano Individual de Atendimento (PIA) previsto no SINASE como um instrumento pedagógico que garante a imparcialidade e a equidade no processo socioeducativo, uma vez que o desenvolvimento institucional do adolescente internado está diretamente ligado às conquistas das metas por ele estabelecidas.

A elaboração do PIA - importante ferramenta no acompanhamento da evolução pessoal e social do adolescente - se inicia na acolhida do adolescente no programa de atendimento com a realização de um diagnóstico polidimensional nas áreas jurídica, de saúde, psicológica, social e pedagógica. Então é realizado pelos técnicos o plano individual de atendimento, estabelecendo metas e compromissos ${ }^{247}$, os quais devem ser constantemente pactuados com o adolescente e sua família durante o cumprimento da MSE.

Os parâmetros da ação socioeducativa estão organizados em 8 eixos estratégicos: (1) suporte institucional e pedagógico; (2) diversidade étnico-racial, de gênero e de orientação sexual; (3) cultura, esporte e lazer; (4) saúde; (5) escola; (6) profissionalização/trabalho/previdência; (7) família e (8) comunidade e segurança.

Com relação ao eixo educacional do PIA, o SINASE estabelece como obrigação comum, a todas às entidades e programas que executam a internação provisória e as MSEs, a garantia do fornecimento educacional (acesso à educação) através de parcerias com órgãos do Executivo, da criação de estrutura e organização escolar. Vejamos:

1) consolidar parcerias com Órgãos executivos do Sistema de Ensino visando o cumprimento do capítulo IV (em especial os artigos 53, 54, 56, e 57) do ECA e, sobretudo, a garantia de regresso, sucesso e permanência dos adolescentes na rede formal de ensino;

2) redirecionar a estrutura e organização da escola (espaço, tempo, currículo) de modo que favoreça a dinamização das

\footnotetext{
246 Sistema Nacional de Atendimento Socioeducativo - SINASE/ Secretaria Especial dos Direitos Humanos - Brasília-DF: CONANDA, 2006.p. 41-42.

247 As metas são relativas à escolarização, profissionalização, cultura, lazer e esporte, oficinas e autocuidado, devendo enfocar interesses, potencialidades, dificuldades, necessidades, avanços e retrocessos.
} 
ações pedagógicas, o convívio em equipes de discussões e reflexões e que estimulem o aprendizado e as trocas de informações, rompendo, assim, com a repetição, rotina e burocracia;

3) propiciar condições adequadas aos adolescentes para a apropriação e produção do conhecimento;

4) garantir o acesso a todos os níveis de educação formal aos adolescentes inseridos no atendimento socioeducativo de acordo com sua necessidade;

5) estreitar relações com as escolas para que conheçam a proposta pedagógica das entidades e/ou programas que executam o atendimento socioeducativo e sua metodologia de acompanhamento aos adolescentes;

6) desenvolver os conteúdos escolares, artísticos, culturais e ocupacionais de maneira interdisciplinar no atendimento socioeducativo; e

7) permitir o acesso à educação escolar considerando as particularidades do adolescente com deficiência, equiparando as oportunidades em todas as áreas (transporte, materiais didáticos e pedagógicos, equipamento e currículo, acompanhamento especial escolar, currículo, capacitação de professores, instrutores e profissionais especializados, entre outros) de acordo com o Decreto ${ }^{\circ}$ 3.298/99.",248

A importância do SINASE e de seus instrumentos (a exemplo do PIA) para a aplicação de MSE é bastante clara. Um diagnóstico do Departamento de Monitoramento e Fiscalização do Sistema Carcerário $\left(\mathrm{DMF} / \mathrm{CNJ}^{249}\right)$, através do "Programa Justiça ao Jovem", nos mostra, em seu Gráfico 24, o percentual de aplicação do PIA nos processos por ele analisados.

\footnotetext{
${ }^{248}$ Sistema Nacional De Atendimento Socioeducativo -SINASE/ Secretaria Especial dos Direitos Humanos - Brasília-DF: CONANDA, 2006.p. 59.

${ }^{249}$ O Departamento de Monitoramento e Fiscalização do Sistema Carcerário e do Sistema de Execução de Medidas Socioeducativas (DMF) foi criado pela Lei n. 12.106, de 2 de dezembro de 2009.
} 
Gráfico 24 - Aplicação do PIA nos processos analisados nas regiōes

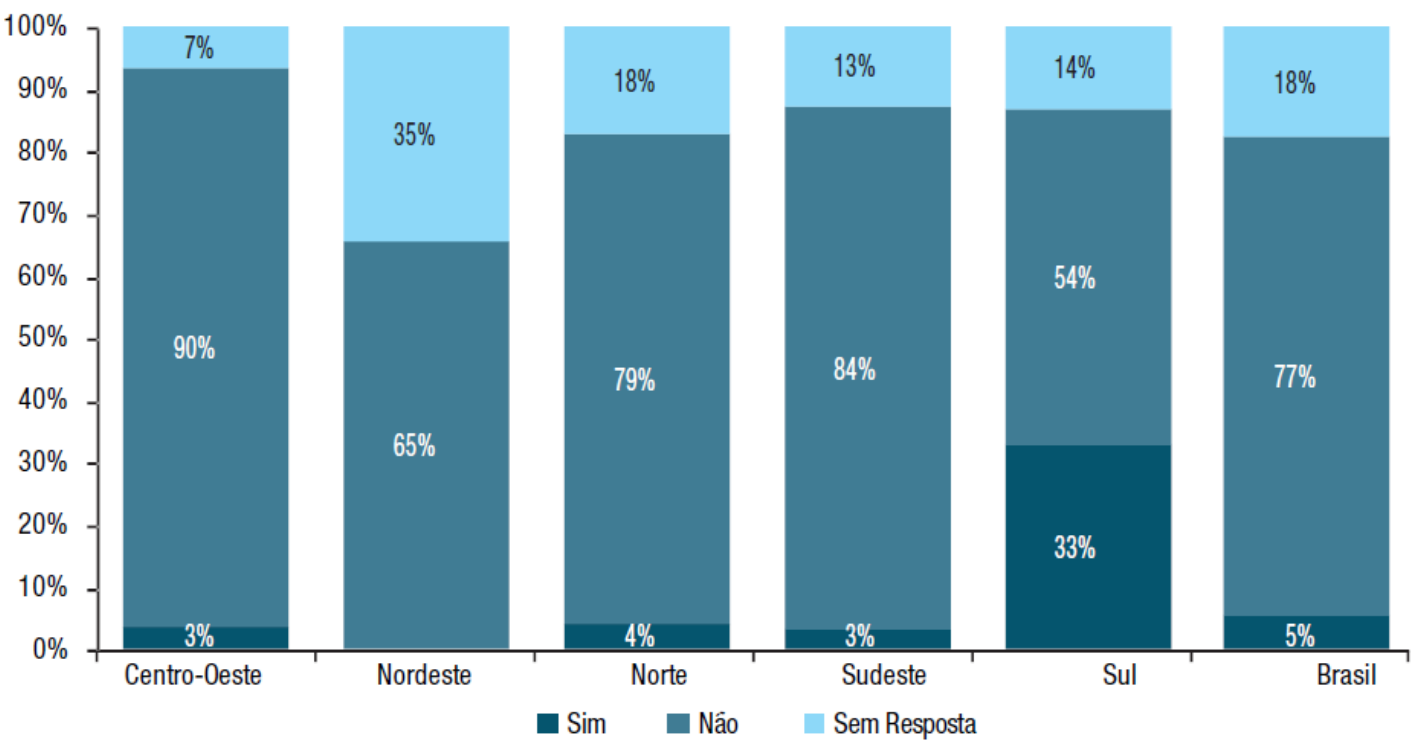

Fonte: DMF/CNJ - Elaboração: DPJ/CNJ

Podemos observar que apenas $5 \%$ dos processos analisados tem informação quanto à aplicação do PIA para os adolescentes, de modo que em $77 \%$ dos processos o plano não é aplicado. O PIA é mais utilizado na Região Sul (33\% de aplicação), enquanto nas demais regiões o índice mais alto é de 4\%, na Região Norte.

Verifica-se, que, na prática, o PIA ainda não é aplicado aos processos de internação dos adolescentes em conflito com a lei, conforme prevê o SINASE, sendo uma significativa perda para o cumprimento da MSE e obtenção de seus objetivos.

\section{g. O Centro de Atendimento Socioeducativo ao Adolescente - Fundação CASA-SP}

Centro de Atendimento Socioeducativo ao Adolescente (CASA) é o novo nome que se dá à conhecida Fundação de Bem Estar do Menor (FEBEM). A Fundação CASA tenta romper com o histórico de violações que estava relacionado à FEBEM, cujas rebeliões e noticias de violência estiveram muito presentes na mídia no final dos anos 90 e início de 2000.

A Fundação CASA é uma instituição vinculada à Secretaria de Estado da Justiça e da Defesa da Cidadania, criada por meio de lei sancionada em 22 de dezembro de 2006 pelo então governador Cláudio Lembo. Sua missão primordial é a aplicação de medidas socioeducativas, conforme as diretrizes e normas previstas no ECA e no SINASE. Ela presta assistência a jovens de 12 a 21 anos incompletos em todo o Estado 
de São Paulo inseridos em medidas socioeducativas de privação de liberdade (internação) e semiliberdade aplicadas de acordo com o tipo de ato infracional e a idade dos adolescentes.

O Estado de São Paulo possui 141 unidades da Fundação CASA com uma população de mais de 8.333 internos. Destes 59 estão em atendimento inicial, 2.337 em internação provisória, 5.3579 em internação e 560 em semiliberdade ${ }^{250}$. Os internos se encontram distribuídos nos seguintes tipos de estabelecimentos:

- CASA - Centros de Atendimento Socioeducativo ao Adolescente: unidades construídas para abrigar os jovens que cumprem medidas socioeducativas de privação de liberdade (internação) e semiliberdade.

- CAI - Centros de Atendimento Inicial: criados para receber adolescentes para internação inicial, enquanto corre o prazo de cinco dias para indicar a unidade para onde serão destinados os jovens.

- NAI - Núcleos de Atendimento Integrado: núcleo gerenciado pela Fundação CASA em parceria com os municípios. Criado nos moldes do artigo 88, inciso $\mathrm{V}$ do ECA, para prestar o atendimento inicial e provisório aos adolescentes, possui um serviço integrado que reúne representantes do Judiciário, Ministério Público, Polícia Militar e Conselho Tutelar, visando promover atuação em rede junto ao jovem. O NAI acolhe e recebe adolescentes encaminhados pela Polícia, evitando a sua permanência em delegacias ou Unidades distantes da sua família, além de realizar encaminhamentos necessários à Rede Municipal de Serviços. O NAI possui também uma Unidade de Atendimento Inicial (UAI) para adolescentes em regime de Internação e uma Unidade de Internação Provisória (UIP), onde o adolescente pode ficar por até 45 dias.

- CAIP - Centros de Atendimento Inicial e Provisório: Local no qual os jovens que cometeram ato infracional podem permanecer por um prazo de até 40 dias, enquanto esperam decisão sobre as medidas socioeducativas determinadas pela Justiça. Durante o período que

\footnotetext{
${ }^{250}$ Dados retirados do sítio eletrônico: http://www.fundacaocasa.sp. gov.br/ Acesso em 12.11.2012.
} 
estão no CAIP, é prestada assistência ao jovem, como, por exemplo, o acompanhamento de psicólogos e assistentes sociais.

O Estado de São Paulo possui 11 divisões regionais, criadas pela Fundação CASA, para descentralizar ${ }^{251} \mathrm{o}$ atendimento socioeducativo ao adolescente, buscando aprimorar a qualidade do atendimento e assim tornar a gestão mais eficiente. O objetivo é fazer com que os adolescentes sejam atendidos próximos de sua família e dentro de sua comunidade, facilitando a reinserção social. Tanto que jovens em medidas socioeducativas em meio aberto (liberdade assistida e prestação de serviços à comunidade) têm seu atendimento supervisionado pela Secretaria de Estado da Assistência e Desenvolvimento Social (municipalização do atendimento). As divisões regionais existentes são:

- DRM I - DIV. REGIONAL METROPOLITANA I (Franco da Rocha) $)^{252}$ - Com 15 unidades;

- DRM II - DIV. REGIONAL METROP. II Leste 1 (Tatuapé) ${ }^{253}$ Com 16 unidades;

- DRM III - DIV. REGIONAL METROP. III Leste $2^{254}$ - Com 9 unidades;

- DRM IV - DIV. REGIONAL METROP. IV OESTE (Raposo Tavares) ${ }^{255}$ - Com 17 unidades;

\footnotetext{
${ }^{251}$ Esta descentralização político-administrativa mediante a criação e a manutenção de programas específicos é prevista nos artigos 204, inc. I, da Constituição Federal e 88, inc. II, do ECA.

${ }^{252}$ (1) CASA Atibaia; (2) CASA Bragança Paulista; (3) CASA Dom Gabriel Paulino Bueno Couto Jundiaí; (4) CASA Sorocaba I; (5) CASA Sorocaba II; (6) CASA Sorocaba III; (7) CASA Sorocaba IV; (8) CASA Franco da Rocha, (9) CASA Novo Tempo; (10) CASA Franco da Rocha; (11) CASA Jacarandá, (12) CASA Rio Negro, (13) CASA Tapajós, (14) CASA Semiliberdade Jundiaí, (15) CASA Semiliberdade Sorocaba.

${ }^{253}$ (1) CASA Ferraz de Vasconcelos I; (2) CASA Ferraz de Vasconcelos II; (3) CASA Novo Horizonte Guaianazes I; (4) CASA Guaianazes II; (5) CASA Encosta Norte; (6) CASA Fazenda do Carmo; (7) CASA Vila Conceição; (8) CASA Chiquinha Gonzaga; (9) CASA Itaquera; (10) CASA Semiliberdade Azaléia - Zona Leste; (11) CASA Semiliberdade Fênix - Zona Leste; (12) CASA Semiliberdade Prof. Paulo Freire - Zona Leste; (13) CASA Semiliberdade Sabará - Zona Leste; (14) CASA Semiliberdade Umbó - Zona Leste; (15) CASA Semiliberdade Uraí - Zona Leste; (16) CASA Semiliberdade São Mateus-Zona Leste

${ }^{254}$ (1) CAI Gaivota; (2) CASA Itaparica; (3) CASA Rio Paraná; (4) CASA Rio Turiassú; (5) CASA Rio Nilo; (6) CASA Rio Tocantins; (7) CASA Topázio; (8) CASA Juquiá; (9) CASA Rio Tâmisa.

${ }^{255}$ (1) CASA Osasco I; (2) CASA Osasco II; (3) CASA Pirituba; (4) CASA Nova Aroeira; (5) CASA Cedro; (6) CASA Ipê; (7) CASA Jatobá; (8) CASA Nogueira; (9) CASA Vila Leopoldina; (10) CASA Jardim São Luiz I; (11) CASA Jardim São Luiz II; (12) CASA Feminina Parada de Taipas; (13) CASA Semiliberdade Guararema; (14) CASA Semiliberdade Jacirendi; (15) CASA Semiliberdade Araré; (16) CASA Semiliberdade Nundiaú; (17) CASA Semiliberdade Ibituruna.
} 
- DRM V - DIV. REGIONAL METROP. V NORTE (Vila Maria) ${ }^{256}$

- Com 14 unidades;

- DRMC - DIV. REGIONAL METROPOLITANA CAMPINAS (Campinas) $^{257}$ - Com 10 unidades;

- DRVP - DIV. REGIONAL VALE DO PARAIBA (Jacarei) ${ }^{258}$ Com 9 unidades;

- DRN - DIVISÃO REGIONAL NORTE (Ribeirão Preto) ${ }^{259}$ - Com 16 unidades;

- DRL - DIVISÃO REGIONAL LITORAL (Praia Grande) $)^{260}$ - Com 13 unidades;

- DRO - DIVISÃO REGIONAL OESTE (Marilia) ${ }^{261}$ - Com 13 unidades;

- DRS - DIVISÃO REGIONAL SUDOESTE - ${ }^{262}$ Com 11 unidades.

Cabe a cada Centro de Atendimento apresentar, anualmente, o Plano Político Pedagógico que englobará todos os aspectos do trabalho a ser desenvolvido na execução da medida socioeducativa, de âmbito técnico e administrativo, a partir do levantamento das necessidades do adolescente e de sua família, das especificidades

\footnotetext{
256 (1) CASA Itaqua I; (2) CASA Itaqua II; (3) CASA Vila Guilherme; (4) CASA Bela Vista; (5) CASA Bom Retiro; (6) CASA Nova Vida; (7) CASA Paulista; (8) CASA Ouro Preto; (9) CASA João do Pulo; (10) CASA São Paulo; (11) CASA Belém; (12) CASA Semiliberdade Alvorada; (13) CASA Semiliberdade Caetanos; (14) CASA Semiliberdade Ícaro - Zona Norte.

257 (1) CASA Maestro Carlos Gomes; (2) CASA Campinas; (3) CASA Mogi Mirim; (4) CASA Laranjeiras; (5) CASA Rio Piracicaba; (6) CASA Escola Rio Claro; (7) CASA Jequitibá; (8) CASA Rio Amazonas; (9) NAI Americana; (10) CASA Semiliberdade Mogi Mirim.

258 (1) CASA Arujá; (2) CASA Jacarei; (3) CASA Taubaté; (4) CASA Tamoios; (5) CASA Caraguatatuba; (6) CASA Guarulhos I; (7) CASA Guarulhos II; (8) CASA Guarulhos Feminino; (9) CASA Lorena

259 (1) CASA Arcebispo D.Hélder Câmara - CASA Franca; (2) CASA Taquaritinga; (3) CASA São Carlos; (4) CASA Batatais; (5) CASA Araraquara; (6) CASA Ouro Verde; (7) CASA Ribeirão Preto; (8) CASA Rio Pardo; (9) CASA Sertãozinho; (10) NAI Ribeirão Preto; (11) NAI São Carlos; (12) CASA Semiliberdade Araraquara; (13) CASA Semiliberdade Barretos; (14) CASA Semiliberdade Batatais; (15) CASA Semiliberdade Ribeirão Preto; (16) CAIP Arcebispo D. Hélder Câmara - CAIP Franca

260 (1) CASA Peruibe; (2) CASA Mauá; (3) CASA Itanhaém; (4) CASA Mongaguá; (5) CASA Praia Grande I; (6) CASA Praia Grande II; (7) CASA São Bernardo I; (8) CASA São Bernardo II; (9) CASA Guarujá; (10) CASA V São Vicente; (11) NAI Santos; (12) CASA Semiliberdade Diadema; (13) CAIP Guarujá.

${ }^{261}$ (1) CASA Araçatuba; (2) CASA Irapuru I; (3) CASA Irapuru II; (4) CASA Mirassol; (5) CASA São José Rio Preto; (6) CASA Araçá; (7) CASA Marília; (8) CASA Tanabi; (9) CASA Rio Dourado - Lins; (10) CASA Vitória Régia - Lins; (11) CASA Semiliberdade Fernandópolis; (12) CASA Semiliberdade São Jose Rio Preto; (13) CASA Semiliberdade Marília

262 (1) CASA Botucatu; (2) CASA Feminino Cerqueira Cesar I; (3) CASA Feminino Cerqueira Cesar II; (4) CASA Cerq Cesar III; (5) CASA Esperança; (6) CASA Madre Teresa de Calcutá I - Iáras; (7) CASA Madre Teresa de Calcutá II - Iáras; (8) CASA Bauru; (9) CASA Rio Novo - Iáras; (10) CASA Três Rios - Iáras; (11) CASA Semiliberdade Bauru
} 
regionais e das características definidas para atendimento (Artigo 10 do Regimento Interno da Fundação CASA).

\section{h. O fornecimento educacional na Fundação CASA: O Projeto Educação e Cidadania e outros projetos.}

A escolarização dentro da Fundação CASA se dá através de diversos projetos conforme o tipo de MSE de privação de liberdade que o jovem cumpre (internação provisória, internação, semiliberdade)

Os adolescentes em internação provisória (cuja permanência é de até 45 dias) integram o Projeto Educação e Cidadania (PEC) que é baseado na Pedagogia de Projetos, criada e desenvolvida pelo Centro de Estudos e Pesquisas em Educação, Cultura e Ação Comunitária (Cenpec). O PEC (Resolução/SEE 109/2003) consiste em uma proposta de escolarização não seriada (ou disseriada) e com currículo diferenciado, visando atender o caráter transitório de permanência do aluno na unidade de internação. Os conteúdos multisseriados possibilitam o agrupamento dos alunos independente do seu nível de escolaridade e do seu domínio da escrita, usualmente abordando assuntos referentes ao mundo contemporâneo.

Os conteúdos do currículo tradicional são abordados através de temas transversais, em módulos e oficinas independentes e tem como eixos norteadores: Cidadania, Ética e Identidade. Os conteúdos são: Educação - ponte para o mundo; Justiça e Cidadania; Família e relações sociais; Saúde - uma questão de cidadania e o Trabalho em nossas vidas. ${ }^{263}$

Aos adolescentes que cumprem medida socioeducativa de internação adotam-se as Propostas Curriculares dos Cursos de Ensino Fundamental e Médio regulares da Rede de Ensino Estadual com a diferença de que a realização destas se dá dentro das especificidades da medida.

Como grande parte dos adolescentes que cumprem a medida socioeducativa de internação tem defasagem escolar em relação à idade, durante o período de internação eles são inseridos no Projeto Revitalizando a Trajetória Escolar (PRTE), que busca o "desenvolvimento de habilidades e competências por meio da contextualização

\footnotetext{
${ }^{263}$ Dados retirados do sítio eletrônico: http://www.fundacaocasa.sp. gov.br/ Acesso em 12.07.2011.
} 
do ensino, em que o aluno é incentivado a analisar, comparar, confrontar e sintetizar o conhecimento",264.

\begin{tabular}{|c|c|}
\hline \multicolumn{2}{|c|}{ As salas de aula nos centros são dividas por níveis } \\
\hline Nível 1 & da $1^{\mathrm{a}}$ a $4^{\mathrm{a}}$ série ou $5^{\circ}$ ano \\
\hline Nível 2 & da $5^{\mathrm{a}}$ a $8^{\mathrm{a}}$ série ou $9^{\circ}$ ano \\
\hline Nível 3 & da $1^{\mathrm{a}}$ a $3^{\mathrm{a}}$ série do ensino médio \\
\hline
\end{tabular}

O maior desafio em relação aos adolescentes privados de liberdade é garantir acesso a uma educação de qualidade que não se limite ao ensino de habilidades e de conteúdos da herança cultural da humanidade, mas que exercite no jovem curiosidade e o instrumentalize para além do domínio de conteúdos, e contribua para que desenvolva postura protagonista e autônoma. Outro grande desafio está na execução de ações complementares à educação escolar formal (escolarização), como a educação profissional, educação para os esportes e a cultura.

Os adolescentes atendidos em centros socioeducativos de São Paulo devem ter acesso obrigatório ao ensino formal ou educação escolar, sendo este trabalho coordenado pela Gerência de Educação Escolar da Superintendência Pedagógica, através de parceria realizada com a Secretaria de Estado da Educação.

A proposta educacional deve considerar a heterogeneidade de idade, de aprendizagem e de escolaridade, o histórico de vida do adolescente, o fato de haver grande rotatividade no cumprimento da MSE, além de fatores psicológicos sensíveis à educação como a instabilidade emocional e o afastamento do convívio familiar.

As turmas e classes escolares instaladas nas unidades da Fundação CASA pertencem administrativamente às escolas da Rede Estadual de Ensino, de modo que a emissão e expedição da documentação escolar são de responsabilidade da Secretaria de Estado da Educação e das escolas a ela vinculadas.

Cumpre mencionar que a ação pedagógica da Fundação CASA não deve se restringir ao ensino formal, havendo atividades distribuídas e coordenadas por quatro gerências, quais sejam: Escolar, Educação Profissional, Arte e Cultura e Esportes.

\footnotetext{
${ }^{264}$ Dados retirados do sítio eletrônico: http://www.fundacaocasa.sp. gov.br/ Acesso em 15.10.2012.
} 


\title{
IV - DIREITO À EDUCAÇÃO DO ADOLESCENTE EM SITUAÇÃO DE PRIVAÇÃO DE LIBERDADE
}

1. Fontes do direito à educação em situações de privação de liberdade. 2. O fornecimento educacional do adolescente em conflito com a lei e a visão do Judiciário

\section{Fontes do direito à educação nas prisões}

\section{a. Legislação Nacional}

\section{i. Programa Nacional de Direitos Humanos}

O Programa Nacional de Direitos Humanos (PNDH) é um programa do Governo Federal do Brasil, criado para ser um marco de referência e um compromisso do país com "a proteção de mulheres e homens, crianças e idosos, das minorias e dos excluídos" (PNDH-I). Elaborado a partir de ampla consulta à sociedade, na qual entidades e civis participaram de debates e seminários, formulando sugestões e críticas.

São três as versões do PNDH, sendo que as versões I (Decreto ${ }^{\circ} 1.904$, de 13 de maio de 1996) e II (Decreto $n^{\circ} 4.229$, de 13 de maio de 2002) foram publicadas durante o governo FHC, e o PNDH III, durante o governo Lula (Decreto ${ }^{\circ}$ 7.177, de 12 de maio de 2010).

O PNDH busca, assim, "consolidar os alicerces da democracia”, elencados pelo ex-presidente Lula como sendo

\begin{abstract}
o diálogo permanente entre Estado e sociedade civil; transparência em todas as esferas de governo; primazia dos Direitos Humanos nas políticas internas e nas relações internacionais; caráter laico do Estado; fortalecimento do pacto federativo; universalidade, indivisibilidade e interdependência dos direitos civis, políticos, econômicos, sociais, culturais e ambientais; opção clara pelo desenvolvimento sustentável; respeito à diversidade; combate às desigualdades; erradicação da fome e da extrema pobreza. ${ }^{265}$ (PNDH-III).
\end{abstract}

O PNDH-III incorpora as resoluções da $11^{\text {a }}$ Conferência Nacional de Direitos Humanos e propostas aprovadas nas mais de 50 conferências nacionais temáticas (segurança alimentar, igualdade racial, educação, habitação, saúde, direitos da mulher, juventude, crianças e adolescentes, pessoas com deficiência, idosos, meio

\footnotetext{
${ }^{265}$ Programa Nacional de Direitos Humanos III. Decreto no 7.037 , de 21 de Dezembro de 2009. Disponível em http://portal.mj.gov.br/sedh/pndh3/pndh3.pdf Acesso em 23.11.2012.
} 
ambiente, entre outros temas de direitos humanos). Concebendo a proteção aos direitos humanos como uma ação integrada de governo, uma política de Estado.

Durante a elaboração do plano, na $8^{\mathrm{a}}$ Conferência Nacional dos Direitos da Criança e do Adolescente, foi discutida a elaboração de um plano decenal para esse segmento e avaliada a implantação do SINASE.

O PNDH-I colocava a Educação dentre as "Propostas de Ações Governamentais" de três diferentes maneiras. A primeira trata da educação como meio de capacitação dos profissionais da área da segurança e lideranças populares, no item “Conscientização e mobilização pelos direitos humanos. Educação e Cidadania. Bases para uma cultura de Direitos Humanos", entre as ações de "Curto prazo":

Apoiar programas de informação, educação e treinamento de direitos humanos para profissionais de direito, policiais, agentes penitenciários e lideranças sindicais, associativas e comunitárias, para aumentar a capacidade de proteção e promoção dos direitos humanos na sociedade brasileira. ${ }^{266}$ $(\mathrm{PNDH}-\mathrm{I})$.

A segunda, como instrumento de desenvolvimento social, no item "Produção e distribuição de informações e conhecimento. Educação e Cidadania. Bases para uma cultura de Direitos Humanos", entre as ações de "Curto prazo":

Criar e fortalecer programas de educação para o respeito aos direitos humanos nas escolas de primeiro, segundo e terceiro grau, através do sistema de 'temas transversais' nas disciplinas curriculares, atualmente adotado pelo Ministério da Educação e do Desporto, e através da criação de uma disciplina sobre direitos humanos. (PNDH - I).

Por fim, a educação aparece como meio de ressocialização, no item "Penas privativas de liberdade", em meio às ações de "Médio prazo":

Promover programas de educação, treinamento profissional e trabalho para facilitar a reeducação e recuperação do preso $(\mathrm{PNDH}-\mathrm{I})$.

Já o PNDH-III trata da educação em seu Eixo Orientador III (Universalizar Direitos em um Contexto de Desigualdades) tratando da necessidade do acesso à educação de qualidade e garantia de permanência na escola como forma de alcançar à diretriz sete do plano: Garantia dos Direitos Humanos de forma universal, indivisível e

\footnotetext{
${ }^{266}$ Programa Nacional de Direitos Humanos I. Decreto no 1.904, de 13 de maio de 1996. Disponível em < http://www.dhnet.org.br/dados/pp/pndh/textointegral.html > Acesso em 23.11.2012.
} 
interdependente, assegurando a cidadania plena; e em seu Eixo Orientador V (Educação e Cultura em Direitos Humanos) buscando alcançar as diretrizes 18 (Efetivação das diretrizes e dos princípios da política nacional de educação em Direitos Humanos para fortalecer cultura de direitos), 19 (Fortalecimento dos princípios da democracia e dos Direitos Humanos nos sistemas de educação básica, nas instituições de ensino superior e nas instituições formadoras, 20 (Reconhecimento da educação não formal como espaço de defesa e promoção dos Direitos Humanos) e 21 (Promoção da Educação em Direitos Humanos no serviço público).

Dentre as ações programáticas da diretriz 20, a ação "g" trata da educação dos jovens em privação de liberdade:

g) Fortalecer experiências alternativas de educação para os adolescentes, bem como para monitores e profissionais do sistema de execução de medidas socioeducativas.

Responsáveis: Secretaria Especial dos Direitos Humanos da Presidência da República; Ministério da Educação; Ministério da Justiça.

Com relação às crianças e adolescentes o PNDH-III tem metas a curto prazo como: Apoiar o funcionamento do Conselho Nacional dos Direitos da Criança e do Adolescente (CONANDA) (meta 92) e incentivar a criação de estruturas para o desenvolvimento de programas socioeducativos para o atendimento de adolescentes infratores (meta 97); metas a médio prazo como investir na formação e capacitação de profissionais e encarregados da implementação da política de direitos da criança e do adolescente nos Governos estaduais e municipais e nas organizações não governamentais (meta 111).

Tem, ainda metas a longo prazo diretamente relacionadas aos adolescentes em conflito como a lei como a de incentivar o reordenamento das instituições privativas de liberdade para menores infratores, reduzindo o número de adolescentes autores de ato infracional por unidade de atendimento, com prioridade na implementação das demais medidas socioeducativas previstas no Estatuto da Criança e do Adolescente (meta 113) e apoiar a criação, pelo Poder Judiciário, Ministério Público e pelos Governos estaduais, de varas, promotorias e delegacias especializadas em infrações penais envolvendo menores, como previsto no Estatuto da Criança e do Adolescente (meta 114). 
O PNDH-III tem diversas propostas de ações governamentais - desde assegurar a implantação e o funcionamento adequado dos órgãos que compõem o Sistema de Garantia de Direitos de Crianças e Adolescentes (proposta 129) e promover a discussão do papel do Poder Judiciário, do Ministério Público, da Defensoria Pública e do Poder Legislativo na implementação do ECA (proposta 130) - que visam a proteção e garantia em rede dos direitos das crianças e adolescentes, até propostas específicas aos adolescentes em conflito com a lei, e/ou que se encontram privados de liberdade que são as propostas 155 a 159 que dispõem:

155. Priorizar as medidas socioeducativas em meio aberto para $\mathrm{o}$ atendimento dos adolescentes em conflito com a lei.

156. Incentivar o reordenamento das instituições privativas de liberdade para adolescentes em conflito com a lei, reduzindo o número de internos por unidade de atendimento e conferindo prioridade à implementação das demais medidas socioeducativas previstas no ECA, em consonância com as resoluções do CONANDA.

157. Incentivar o desenvolvimento, monitoramento e avaliação de programas socioeducativos para $o$ atendimento de adolescentes autores de ato infracional, com a participação de seus familiares.

158. Fortalecer a atuação do Poder Judiciário e do Ministério Público na fiscalização e aplicação das medidas socioeducativas a adolescentes em conflito com a lei.

159. Promover a integração operacional de órgãos do Poder Judiciário, Ministério Público, Defensorias Públicas e Secretarias de Segurança Pública com as delegacias especializadas em investigação de atos infracionais praticados por adolescentes e às entidades de atendimento, bem como ações de sensibilização dos profissionais indicados para esses órgãos quanto à aplicação do ECA.

O que nos mostra a necessidade de implementação da oferta educacional para aqueles que se encontram cumprindo medida privativa de liberdade, como meta a ser perseguida e como forma de instrumentalizar o interno para a vida extramuros, bem como a necessidade de integração dos diversos órgãos governamentais como Poder Judiciário, Ministério Público, Defensorias Públicas e Secretarias de Segurança Pública com entidades da sociedade civil. 


\section{ii. Programa Estadual de Direitos Humanos do Estado de São Paulo - PEDH-SP}

O Programa Estadual de Direitos Humanos, instituído pelo decreto $\mathrm{n}^{\circ}$ 42.209 de 15 de setembro de 1997, cria a Comissão Especial de acompanhamento da execução desse programa além de instituir propostas de ações governamentais para a garantia e proteção dos direitos humanos no estado de São Paulo. Elaborado e discutido com a participação da sociedade civil o PEDH-SP tem como proposta a (1) construção da Democracia e promoção dos Direitos Humanos, em que os principais objetivos são a educação para a Democracia e os Direitos Humanos e a participação política; (2) a proteção de direitos econômicos, sociais, culturais e ambientais, que envolve desde o direito ao desenvolvimento humano e o emprego e geração de renda até a garantia do direito à educação; e (3) a proteção de direitos civis e políticos, como o acesso à justiça e luta contra a impunidade, segurança e medidas contra a violência e sistema prisional e ressocialização, medidas contra a discriminação, e a proteção de grupos como crianças e adolescentes, mulheres, população negra, povos indígenas, refugiados e migrantes, terceira idade, pessoas portadoras de deficiência e homossexuais e transexuais.

A proteção de crianças e adolescentes no PEDH-SP vai desde a implementação de campanhas para proteção e promoção dos seus direitos; como a melhora da infraestrutura para o adequado funcionamento do Conselho Estadual dos Direitos da Criança e do Adolescente, incentivo a criação e funcionamento de Conselhos Municipais de Direitos, Conselhos Tutelares e Fundos dos Direitos da Criança e do Adolescente.

A orientação e assistência jurídica nos processos envolvendo crianças ou adolescentes e o apoio à criação e funcionamento de varas, promotorias e delegacias especializadas em infrações penais envolvendo crianças e adolescentes também são objetivos do plano, como:

5.16. Reorganizar e regionalizar os estabelecimentos destinados à internação de adolescentes autores de ato infracional, de acordo com as regras previstas no Estatuto da Criança e do Adolescente, com participação da comunidade.

5.17. Desenvolver ação integrada do Poder Executivo com o Poder Judiciário e Ministério Público, aperfeiçoando o sistema de aplicação de medidas socioeducativas aos adolescentes autores de ato infracional. 
5.18. Priorizar programas que privilegiem a aplicação de medidas socioeducativas não privativas da liberdade para adolescentes autores de ato infracional.

5.19. Estabelecer um sistema estadual de monitoramento da situação da criança e do adolescente, com atenção particular para a identificação e localização de crianças, adolescentes e familiares desaparecidos, combate à violência contra a criança e $o$ adolescente, e atendimento aos autores de ato infracional.

Assim, considerando que a melhoria do ensino público e a garantia de acesso, reingresso e permanência nos ensinos fundamental e médio também são objetivos do plano, este não distingue crianças e adolescentes em conflito com a lei dos demais, devendo a educação de todos ser garantida e promovida.

Para alcançar todos estes objetivos que elencamos o PEDH-SP também dispõe da implementação e do monitoramento das políticas de direitos humanos como a criação de núcleos, o acompanhamento e apoio as prefeituras municipais no cumprimento das obrigações mínimas de proteção e promoção dos direitos humanos. Além do apoio à criação e ao funcionamento de conselhos municipais de defesa dos direitos humanos e de defesa da cidadania, de comissões de direitos humanos nas câmaras municipais, da Comissão de Direitos Humanos da Assembleia Legislativa, entre iniciativas de outros órgãos.

\section{iii. Estatuto da Criança e do Adolescente}

O Estatuto da Criança e do Adolescente é expressão de vitórias institucionais em vários sentidos que demonstram que apesar da realidade de desigualdade que vivemos, ainda existe um movimento por saneamento das injustiças sociais, articulado por parcela da sociedade mais conscientizada, voltada às ações humanizadoras e dotada de visão planetária. Isto porque o Estatuto que traz a já mencionada Doutrina da Proteção Integral e da Prioridade Absoluta, ao plexo legislativo referente à proteção da criança e ao adolescente.

Grande parte dos juristas afirma ser de difícil aplicação o disposto no ECA, devido seu caráter extremamente principiológico e programático, o qual requer planejamento e adaptações da máquina pública, fato que por si só não desonera o Estado de sua responsabilidade em dar cumprimento ao disposto no estatuto.

A educação da criança e do adolescente é tratada no capítulo IV, artigo 53 e seguintes, que a coloca enquanto direito, que deve visar o pleno desenvolvimento e o preparo para o exercício da cidadania e qualificação para o trabalho: 
Art. 53. A criança e o adolescente têm direito à educação, visando ao pleno desenvolvimento de sua pessoa, preparo para o exercício da cidadania e qualificação para o trabalho, assegurando-lhes:

I - igualdade de condições para o acesso e permanência na escola;

II - direito de ser respeitado por seus educadores;

III - direito de contestar critérios avaliativos, podendo recorrer às instâncias escolares superiores;

IV - direito de organização e participação em entidades estudantis;

V - acesso à escola pública e gratuita próxima de sua residência.

Parágrafo único. É direito dos pais ou responsáveis ter ciência do processo pedagógico, bem como participar da definição das propostas educacionais.

Por sua vez, o artigo 54 acaba por reproduzir o disposto no art. 208 da Constituição Federal, referente aos deveres do Estado no que concerne à educação. O Estatuto busca, assim, assegurar à criança e ao adolescente igualdade de condições para o acesso e permanência na escola, obrigação do estado, da família e da sociedade, nos moldes do art. 205 da Constituição Federal.

É notório o posto ocupado pela educação no Estatuto da Criança e do Adolescente, de modo que mesmo quando a criança e o adolescente se encontrarem cumprindo medida socioeducativa pela prática de ato infracional ${ }^{267}$, o direito à educação não pode lhes ser negado.

Isto porque, a medida socioeducativa é tida como a "manifestação do estado, em resposta ao ato infracional (crime ou contravenção penal), praticado por menores de 18 anos, de natureza jurídica impositiva, sancionatória e retributiva, cuja aplicação objetiva inibir a reincidência" ${ }^{268}$ esta não pode ultrapassar outros direitos além da liberdade.

Previsto no ECA, o Conselho Nacional dos Direitos da Criança e do Adolescente (CONANDA) foi criado em 1991, pela Lei $\mathrm{n}^{\circ}$ 8.242, e é tido como o principal órgão do sistema de garantia de direitos da criança e do adolescente. Ele se

\footnotetext{
${ }^{267} \mathrm{O}$ Estatuto diferencia criança (menores de 12 anos) de adolescente (de 12 a 18 anos), prevendo que enquanto para as primeiras se aplicam medidas de proteção (art. 101), aos adolescentes se aplicam as medidas sócio-educativas constantes no art. 112.

${ }^{268}$ LIBERATI, Wilson Donizeti. Comentários ao estatuto da Criança e do Adolescente. $11^{\text {a }}$ ed. São Paulo: Malheiros Editores, 2010. p. 122.
} 
desenvolve através da gestão compartilhada entre governo e sociedade civil, as ações executadas pelo poder público e gere o Fundo Nacional da Criança e do Adolescente (FNCA) e fiscalizar as ações de promoção dos direitos da infância e adolescência executadas por organismos governamentais e não governamentais.

\section{iv. Resolução no 46 de 1996, do Conselho Nacional dos Direitos da Criança e do Adolescente}

O CONANDA, ao criar a Resolução no 46, que regulamenta a execução da medida socioeducativa de internação prevista no ECA (Lei $n^{\circ}$ 8069/90), considera não somente as diretrizes contidas no art. 88, V, do estatuto, e no art. $2^{\circ}$ da Lei $n^{\circ} 8.242$, de 12 de outubro de 1991, mas principalmente que as medidas socioeducativas elencadas no art. 112, devem "assegurar a reinserção social e o resgate da cidadania dos adolescentes em conflito com a lei".

A resolução busca, assim, regulamentar o número de adolescentes a ser atendido por unidade de internação (art. $1^{\circ}$ ), a distribuição destas unidades de maneira regionalizada $\left(\operatorname{art} .2^{\circ}\right)$, além da necessidade de integração de serviços setoriais de atendimento, como a educação, a saúde, o esporte e lazer, a assistência social, a profissionalização, a cultura e a segurança $\left(\operatorname{art} .3^{\circ}\right)$.

Com relação ao fornecimento educacional, a Resolução é clara ao dispor em seu art. $4^{\circ}$ que o interno deverá contar com orientação sociopedagógica, complementando em seu art. $6^{\circ}$ que o projeto sociopedagógico deverá prever a participação da família e da comunidade (dimensão essencial da proteção integral).

Cumpre mencionar que o descumprimento da Resolução implica o encaminhamento de representação ao Ministério Público para os procedimentos legais, de modo a garantir a efetivação da resolução e dos direitos do adolescente que cumpre MSE.

\section{v. Resolução nº 02 de 2010, do Conselho Nacional de Educação - CNE}

As Diretrizes Nacionais para a oferta de educação para jovens e adultos em situação de privação de liberdade nos estabelecimentos penais considera responsabilidades do Estado e da sociedade na garantia do direito à educação para jovens e adultos nos estabelecimentos penais. Estabelecidas pelo MEC, CNE e pela Câmara de Educação Básica, a Resolução no 2 de 19 de maio de 2010 as diretrizes 
utilizam dentre as suas considerações iniciais, questões que foram aprovadas pelas Conferências Internacionais de Educação de Adultos (V e VI CONFINTEA) a Diretriz menciona sua "preocupação de estimular oportunidades de aprendizagem a todos, em particular, os marginalizados e excluídos", buscando garantir o reconhecimento do direito à aprendizagem de todas as pessoas encarceradas ${ }^{269}$, proporcionando-lhes informações e acesso aos diferentes níveis de ensino e formação.

As Diretrizes estabelecem em seu artigo $2^{\circ}$ que a legislação educacional deve se estender aos estabelecimentos prisionais, enquanto seu artigo $3^{\circ}$ a coloca como responsabilidade das Secretarias de Educação Estaduais (no caso dos estabelecimentos estaduais e do Distrito Federal) e do Ministério da Educação e Ministério da Justiça (nos estabelecimentos federais).

Estabelece também que as verbas do Fundo de Manutenção e Desenvolvimento da Educação Básica e de Valorização dos Profissionais da Educação (FUNDEB), destinadas à modalidade de Educação de Jovens e Adultos, devem abranger a educação nas prisões. As orientações para a oferta educacional dispõe desde os órgãos responsáveis pelo fornecimento educacional, as fontes de financiamento, à sua forma de funcionamento e articulações a serem realizadas.

Art. $3^{\circ}$ A oferta de educação para jovens e adultos em estabelecimentos penais obedecerá às seguintes orientações:

I - é atribuição do órgão responsável pela educação nos Estados e no Distrito Federal (Secretaria de Educação ou órgão equivalente) e deverá ser realizada em articulação com os órgãos responsáveis pela sua administração penitenciária, exceto nas penitenciárias federais, cujos programas educacionais estarão sob a responsabilidade do Ministério da Educação em articulação com o Ministério da Justiça, que poderá celebrar convênios com Estados, Distrito Federal e Municípios;

II - será financiada com as fontes de recursos públicos vinculados à manutenção e desenvolvimento do ensino, entre as quais o Fundo de Manutenção e Desenvolvimento da Educação Básica e de Valorização dos Profissionais da Educação (FUNDEB), destinados à modalidade de Educação de Jovens e Adultos e, de forma complementar, com outras fontes estaduais e federais;

III - estará associada às ações complementares de cultura, esporte, inclusão digital, educação profissional, fomento à leitura e a programas de implantação, recuperação e

\footnotetext{
269 As Diretrizes dispõe que as ações de educação são extensivas aos presos provisórios, condenados, egressos do sistema prisional e àqueles que cumprem medidas de segurança.
} 
manutenção de bibliotecas destinadas ao atendimento à população privada de liberdade, inclusive as ações de valorização dos profissionais que trabalham nesses espaços;

IV - promoverá o envolvimento da comunidade e dos familiares dos indivíduos em situação de privação de liberdade e preverá atendimento diferenciado de acordo com as especificidades de cada medida e/ou regime prisional, considerando as necessidades de inclusão e acessibilidade, bem como as peculiaridades de gênero, raça e etnia, credo, idade e condição social da população atendida;

$\mathrm{V}$ - poderá ser realizada mediante vinculação a unidades educacionais e a programas que funcionam fora dos estabelecimentos penais;

VI - desenvolverá políticas de elevação de escolaridade associada à qualificação profissional, articulando-as, também, de maneira intersetorial, a políticas e programas destinados a jovens e adultos;

VII - contemplará o atendimento em todos os turnos;

VIII - será organizada de modo a atender às peculiaridades de tempo, espaço e rotatividade da população carcerária levando em consideração a flexibilidade prevista no art. 23 da Lei $n^{\circ}$ 9.394/96 (LDB).

Interessante notar o disposto no artigo $4^{\circ}$ das Diretrizes que ao tratar das diferentes formas de oferta educacional a serem oferecidas em espaços de privação de liberdade, trazem a possibilidade de educação a distancia (EAD).

Art. $5^{\circ}$ Os Estados, o Distrito Federal e a União, levando em consideração as especificidades da educação em espaços de privação de liberdade, deverão incentivar a promoção de novas estratégias pedagógicas, produção de materiais didáticos e a implementação de novas metodologias e tecnologias educacionais, assim como de programas educativos na modalidade Educação a Distância (EAD), a serem empregados no âmbito das escolas do sistema prisional.

As Diretrizes tratam de orientações a serem obedecidas na oferta de educação para jovens e adultos em estabelecimentos penais, tal qual a atribuição do órgão responsável pela educação nos Estados e no Distrito Federal (Secretaria de Educação ou órgão equivalente) e a necessidade de ações complementares de cultura, esporte, inclusão digital, educação profissional, fomento à leitura e a programas de implantação, recuperação e manutenção de bibliotecas destinadas ao atendimento à população privada de liberdade, bem como a existência de espaços físicos adequados às 
atividades educacionais, esportivas, culturais, de formação profissional e de lazer, integrando-as às rotinas dos estabelecimentos penais.

As Diretrizes também preveem o atendimento diferenciado de acordo com as especificidades de cada medida e/ou regime prisional, como as necessidades de inclusão e acessibilidade, as peculiaridades de gênero, raça e etnia, credo, idade, e as peculiaridades de tempo, espaço e rotatividade da população carcerária levando em consideração a flexibilidade prevista no art. 23 da Lei nº 9.394/96 (LDB).

Soma-se o fato de que em diversas passagens do documento, a necessidade de articulações, convênios, e parcerias com diferentes esferas e áreas de governo, universidades, instituições de Educação Profissional e organizações da sociedade civil, é ressaltada, o que nos mostra a necessidade de lidar com a educação nos estabelecimentos de privação de liberdade como um problema só sanado com o desenho de políticas públicas bem estruturadas.

Art. $6^{\circ}$ A gestão da educação no contexto prisional deverá promover parcerias com diferentes esferas e áreas de governo, bem como com universidades, instituições de Educação Profissional e organizações da sociedade civil, com vistas à formulação, execução, monitoramento e avaliação de políticas públicas de Educação de Jovens e Adultos em situação de privação de liberdade.

Parágrafo Único. As parcerias a que se refere o caput deste artigo dar-se-ão em perspectiva complementar à política educacional implementada pelos órgãos responsáveis pela educação da União, dos Estados e do Distrito Federal.

A educação, assim, será organizada de modo a atender às peculiaridades de tempo, espaço e rotatividade da população carcerária, e contemplará o atendimento em todos os turnos; as autoridades responsáveis deverão propiciar espaços físicos adequados às atividades educacionais, esportivas, culturais, de formação profissional e de lazer $\left(\operatorname{art} .7^{\circ}\right)$, bem como prover materiais didáticos e escolares, apoio pedagógico, alimentação e saúde dos estudantes (art. $8^{\circ}$ ).

A oferta de Educação Profissional nos estabelecimentos penais deverá seguir as Diretrizes Curriculares Nacionais definidas pelo Conselho Nacional de Educação $\left(\operatorname{art.} 9^{\circ}\right.$ ), e as atividades laborais e artístico-culturais são reconhecidas e valorizadas como elementos formativos integrados à oferta de educação, podendo constar no projeto político-pedagógico como atividades curriculares. Esta previsão pode parecer uma forma de dissimular atividades laborais ou oficinas artístico-culturais por 
pedagógicas culturais. Porém, como o artigo 12 dispõe que o planejamento das ações de educação poderá contemplar, além das atividades de educação formal, propostas de educação não-formal, queremos crer que a educação formal é obrigatória.

Os educadores nos estabelecimentos penais deverão levar em consideração as especificidades da política de execução penal (Art. 11). Porém, uma importante diretriz está no parágrafo primeiro do mesmo artigo, ao prever que docentes que atuam nestes espaços deverão ser profissionais do magistério devidamente habilitados e com remuneração condizente com as especificidades da função. Acabando com a tradição até então existente de precarização do fornecimento educacional inframuros ou mesmo com a utilização de profissionais sem titulação ${ }^{270}$ adequada para educar.

A implementação e fiscalização destas Diretrizes será obrigação dos Conselhos de Educação dos Estados e do Distrito Federal, que para isso, deverão articular-se com os Conselhos Penitenciários Estaduais e do Distrito Federal ou seus congêneres (Art. 14).

As Diretrizes vêm, assim, atender as demandas educacionais de material, equipe especializada e verbas, tão reclamadas pelos grupos e organizações que atualmente defendem os direitos dos presos.

\section{b. Legislação Internacional}

i. A Organização das Nações Unidas para a Educação a Ciência e a Cultura e seus desafios e estratégias para a educação

A Organização das Nações Unidas para a Educação, a Ciência e a Cultura, criada em 16 de novembro de 1945, tem como missão contribuir para a construção de uma cultura paz, para a erradicação da pobreza, para o desenvolvimento sustentável e para o diálogo intercultural, por meio da educação.

A UNESCO busca promover o engajamento dos jovens como meio de empoderamento e de prevenção da violência. Para isso ela se utiliza de uma abordagem transversal focalizada na construção de competências que facilitem a transição bemsucedida para a idade adulta. Procurar, assim, integrar as "preocupações e dos

\footnotetext{
${ }^{270}$ Apesar do $\S 2^{\circ}$ do mesmo artigo 11 prever que a pessoa privada de liberdade ou internada que possua perfil adequado e receba preparação especial, pode atuar em apoio ao profissional da educação, esta atuação será um auxilio ao educador, não sua substituição.
} 
problemas dos jovens nas agendas da vida política dos Estados-membros, no que tange à educação, às ciências, à cultura e à comunicação."271

Criado em 1999, o Fórum dos Jovens da Conferência-geral da UNESCO, cujas sessões são bianuais, é uma atividade única em seu gênero no sistema das Nações Unidas, pelo fato de institucionalizar a participação dos jovens no órgão de tomada de decisões mais importante da UNESCO.

Outra preocupação é promover a alfabetização e uma educação de qualidade para todos, ao longo da vida, insistindo com particular ênfase na igualdade de gênero, nos jovens, assim como nos grupos mais vulneráveis e marginalizados da sociedade, incluindo os povos indígenas. A UNESCO se dedica mobilizar a vontade política e a coordenar o empenho de todas as partes interessadas (parceiros, governos, ONGs e sociedade civil), ela coopera em todos os níveis de ensino, buscando promover o acesso, a igualdade, qualidade e a inovação. Para isto, ela tem como estratégia:

1.Ajudar os países a formular e a implementar políticas educacionais;

2. Prestar atenção particular à África e a países menos desenvolvidos e aos nove mais populosos (Bangladesh, Brasil, China, Egito, Índia, Indonésia, México, Nigéria e Paquistão).

3. Desenvolver e divulgar boas práticas, compêndios escolares, kits de formação;

4, Promover resposta global ao HIV/Aids, no Setor da Educação;

5. Incentivar a adoção de medidas especiais, buscando garantir a educação em zonas de conflito e situações de crise;

6. Apoiar o desenvolvimento de programas de ensino e formação (tecnológica e profissionalizante);

7. Definir normas de qualidade para o reconhecimento das qualificações no ensino superior;

8. Negociar parcerias entre atores públicos, privados e não governamentais.

A UNESCO é a agência que comandou a Década das Nações Unidas para a Alfabetização (2003-2012) e a Década das Nações Unidas da Educação para o Desenvolvimento Sustentável (2005-2014). No Brasil, a agenda política prioriza a

271 Sitio eletrônico da UNESCO Brasil - http://www.unesco.org/new/pt/brasilia/specialthemes/preventing-youth-violence/ - consultado em 12.10.2012. 
alfabetização de jovens e adultos, para a qual tem o apoio da UNESCO no compromisso com os objetivos da Educação para Todos (EPT). Assim, ela tem entre seus objetivos estratégicos referentes à política educacional o Objetivo 03 , que estipulou o prazo de 03 anos para que houvesse equidade nas condições de acesso à educação e nos resultados no sistema educacional brasileiro.

Para o Biênio 2008-2009, buscou-se a qualificação de políticas e programas de Alfabetização e Educação de Jovens e Adultos, para a qual foram realizados diversos seminários como o Seminário Alfabetização e Educação de Jovens e Adultos na América Latina: Direito e Desafio realizado; oficinas de qualificação para gestores dos países que compõem a Estratégia Life; a audiência pública na Câmara dos Deputados para apresentação e debate do relatório da RNDHE sobre educação em prisões, dentre outros significativos eventos. Por sua vez o biênio 2010-2011 no que se refere à educação teve como prioridade contribuir ao exito do programa Educação para Todos (EPT) e exercer uma lideraça mundial e regional em matéria de educação, principalmente mediante a aplicação das recomendações das grandes convenções internacionais sobre educação.

O atual biênio 2012-2013 tem como meta a promoção de uma educação mais equitativa e de melhor qualidade ao serviço da aprendizagem ao longo de toda a vida e o desenvolvimento sustentável, bem como mantêm a prioridade de fortalecer sua liderança mundial no âmbito da educação.

\section{ii. Convenção das Nações Unidas sobre os Direitos das Crianças}

Adotada pela Assembleia Geral das Nações Unidas em 20 de novembro de 1989, a Convenção das Nações Unidas sobre os Direitos das Crianças foi aprovada pelo Decreto Legislativo $\mathrm{n}^{\mathrm{o}} 28$, de 14 de setembro de 1990 e promulgada pelo Decreto 99.710 de 21 de novembro de 1990. A Convenção proclama a necessidade de se proporcionar à criança a proteção especial enunciada por diversos tratados internacionais ${ }^{272}$. Cumprindo mencionar que a convenção considera como criança todo ser humano com menos de dezoito anos de idade, havendo a ressalva de quando legislação específica define outra idade para a maioridade.

\footnotetext{
${ }^{272}$ Como na Declaração de Genebra de 1924 sobre os Direitos da Criança e na Declaração dos Direitos da Criança, na Declaração Universal dos Direitos Humanos, no Pacto Internacional de Direitos Civis e Políticos, no Pacto Internacional de Direitos Econômicos, Sociais e Culturais
} 
Na parte I da Convenção, o artigo 28.1 da Convenção dispõe sobre o direito da criança à educação como meio de se exercer progressivamente e em igualdade de condições esse direito, devendo os Estados Partes signatários da Convenção tornar o ensino primário obrigatório e disponível para todos; estimular o desenvolvimento do ensino secundário, ambos gratuitos. Os Estados devem também promover e estimular a cooperação internacional em questões educacionais, facilitando o acesso aos conhecimentos científicos e técnicos; devendo a educação ser orientada no sentido de desenvolver a personalidade, as aptidões e a capacidade mental e física da criança, desenvolver o respeito aos direitos humanos e às liberdades fundamentais, preparar a criança para assumir uma vida responsável.

Mais especificamente no que se refere à privação de liberdade, o artigo 37 traz o obrigação dos Estados Partes em zelar para que nenhuma criança seja privada de sua liberdade de forma ilegal ou arbitrária. Devendo a detenção, a reclusão ou a prisão apenas ocorrer como último recurso, e durante o mais breve período de tempo, sendo direito de toda criança, a quem se alegue ter infringido as leis penais ou a quem se acuse ou declare culpada de ter infringido as leis penais, ser tratada de modo a promover e estimular seu sentido de dignidade e de valor.

A convenção considera direito e garantia de toda criança de quem se alegue ter infringido as leis penais ou a quem se acuse de ter infringido essas leis, de ter plenamente respeitada sua vida privada, bem como serem tratadas de modo apropriado ao seu bem-estar e de forma proporcional às circunstâncias e ao tipo de delito.

A parte II da Convenção trata do compromisso dos Estados Partes em dar aos adultos e às crianças amplo conhecimento dos princípios e disposições da Convenção; do estabelecimento de comissões compostas por especialistas para que realizem estudos especiais sobre assuntos relacionados aos direitos das crianças; de formas de fomento da implantação efetiva da Convenção; e de formas encorajar a cooperação internacional. Por sua vez a parte III trata da ratificação da Convenção pelos Estados (aberta à assinatura e adesão de qualquer Estado).

A convenção busca, assim, elencar direitos e garantias mínimas da criança, devendo ser a educação um direito fundamental a ser garantido, enquanto a punição, além de breve e excepcional, deve respeitar a dignidade e o processo de desenvolvimento da criança. Deste modo, compreende-se que a primeira não pode ser negada ou inviabilizada pela segunda. 


\section{iii. Convenção Relativa à Luta contra a Discriminação no Campo do Ensino}

Soma-se à extensa produção legislativa referente à educação nas prisões, a Convenção Relativa à Luta contra a Discriminação no Campo do Ensino, aprovada em 14 de dezembro de 1960, pela Conferência Geral da UNESCO, em sua $11^{\text {a }}$ sessão, reunida em Paris de 14 de novembro à 15 de dezembro de 1960, ratificada pelo Brasil, e aprovada pelo Congresso Nacional pelo decreto legislativo n. 40, de 1967 que resultou no Decreto no 63.223 - de 6 de setembro de 1968. A Convenção dispõe em seu artigo I:

Para os fins da presente Convenção, o termo "discriminação" abarca qualquer distinção, exclusão, limitação ou preferência que, por motivo de raça, cor, sexo, língua, religião, opinião pública ou qualquer outra opinião, origem nacional ou social, condição econômica ou nascimento, tendo por objetivo ou efeito destruir ou alterar a igualdade de tratamento em matéria de ensino, e, principalmente:

a) privar qualquer pessoa ou grupo de pessoas do acesso aos diversos tipos ou graus de ensino;

b) limitar a nível inferior à educação de qualquer pessoa ou grupo;

c) sob reserva do disposto no artigo 2 da presente Convenção, instituir ou manter sistemas ou estabelecimentos de ensino separados para pessoas ou grupos de pessoas; ou

d) de impor a qualquer pessoa ou grupo de pessoas condições incompatíveis com a dignidade do homem.

$\mathrm{O}$ artigo acima transcrito nos mostra que, sendo a discriminação a privação de qualquer pessoa ou grupo de pessoas do acesso aos diversos tipos ou graus de ensino, devemos nos opor à manutenção de sistemas que imponham a qualquer pessoa condições incompatíveis com a dignidade do homem. Cumpre ao poder público observar as normas existentes não só no âmbito internacional, mas no nacional, quando for desenvolver políticas públicas.

A Convenção define como "ensino" os diversos tipos e graus de ensino, compreendendo o acesso ao ensino, seu nível e qualidade e as condições em que é subministrado. Os Estados parte se comprometem, assim, a fazer cessar quaisquer práticas administrativas que envolvam discriminação; a tomar medidas, inclusive legislativas, para não haver discriminação na admissão de alunos nos estabelecimentos 
de ensino; a não admitir nenhuma preferência ou restrição baseadas unicamente no fato de que os alunos pertençam a determinado grupo (Artigo III).

Para isso, os Estados parte se comprometem a formular, desenvolver e aplicar política nacional que vise a promover a igualdade de oportunidades e tratamento em matéria de ensino (Artigo IV), de modo a tornar o ensino primário obrigatório e gratuito, ampliar o acesso ao ensino secundário, e assegurar a qualidade do ensino fornecido.

A Convenção também dispõe sobre a necessidade da educação visar ao pleno desenvolvimento da personalidade humana e ao fortalecimento do respeito aos direitos humanos e das liberdades fundamentais, favorecendo a compreensão, a tolerância e a amizade entre todas as nações.

Em que pese a Convenção da UNESCO contra a discriminação na educação ser uma das mais antigas normas de direito internacional referentes ao direito à educação, ela ainda está muito longe de ser plenamente efetivada. Quando tratamos do fornecimento de educação de qualidade a todos de maneira equânime e não discriminatória, vemos que ainda há um longo caminho a ser percorrido, principalmente quando tratamos do direito à educação daqueles que se encontram sob a tutela do Estado, isto é, de jovens que se encontram cumprindo medidas socioeducativas de privação de liberdade.

\section{iv. Resolução $n^{0}$ 40/33 da Assembleia Geral, de 29.11.85 - Regras de Beijing}

A elaboração das Regras Mínimas para a Administração da Justiça de Menores foi possível pelo trabalho realizado pelo Comitê para a Prevenção do Crime e a Luta contra a Delinquência, pelo Secretário-Geral da ONU, pelo Instituto das Nações Unidas para a Ásia e o Extremo Oriente e por outros institutos das Nações Unidas, sendo recomendadas pelo Sétimo Congresso das Nações Unidas.

As Regras Mínimas das Nações Unidas para a Administração da Justiça de Menores tem como princípios gerais a intenção de promover o bem-estar do menor e da sua família, criar condições que assegurem ao menor uma vida útil na comunidade fomentando, durante o período de vida em que o menor se encontre mais exposto a um comportamento desviante, um processo de desenvolvimento pessoal e de educação afastado tanto quanto possível de qualquer contato com a criminalidade e a delinquência, além da busca por medidas positivas que assegurem a mobilização de 
todos os recursos (família, voluntários e outros grupos comunitários, escolas e outras instituições comunitárias) a fim de promover o bem-estar do menor e reduzir a necessidade de intervenção da lei, bem como tratar de forma eficaz, equitativa e humanitária o jovem em conflito com a lei. Para isso, a Justiça de menores deve ser concebida como parte integrante do processo de desenvolvimento nacional de cada país (regra 1.4), de modo a garantir a proteção dos jovens e a manutenção da paz e da ordem na sociedade. As medidas de proteção social dos jovens, também deve ser priorizada, de modo a prevenir o crime e a delinquência juvenil.

As Regras Mínimas foram formuladas de forma a serem aplicadas em sistemas jurídicos diferentes, fixando normas mínimas para o tratamento dos delinquentes juvenis, para tanto define os termos "menor" e "delito" em sua regra 2.2. Mesmo com esta flexibilidade, as regras reconhecem que a responsabilidade penal não deve ser fixada a um nível demasiadamente baixo, tendo em conta problemas de maturidade afetiva, psicológica e intelectual (regra 4).

O "princípio da proporcionalidade" é objetivo a ser buscado pela Justiça de menores, de modo que a imposição de sansões deve ser proporcional tanto às circunstâncias especiais dos jovens em conflito com a lei, quanto do delito. Tanto que o poder discricionário deve ser exercido de um modo responsável, em todas as fases do processo e a todos os níveis, afinal os jovens devem ter preservadas suas garantias fundamentais processuais, como a presunção de inocência, o direito de ser notificado das acusações, o direito de não responder, o direito à assistência judiciária, o direito à presença dos pais ou tutor, o direito de interrogar e confrontar as testemunhas e o direito ao recurso.

As regras têm na prisão preventiva uma medida de último recurso, devendo sua duração ser o mais breve possível e quando possível, esta deve ser substituída por outras medidas, tais como uma vigilância apertada, uma assistência muito atenta ou colocação em família, em estabelecimentos ou em lar educativo. Para as regras, a colocação de um menor em instituição, é sempre uma medida de último recurso (regra 19).

As regras também prezam pela necessidade de profissionalização e de formação, de modo que a formação profissional, a formação permanente, os cursos de reciclagem e outros tipos de formação devem ser oferecidos.

A quarta parte das regras trata do tratamento em meio aberto enquanto a quinta do tratamento em instituição, nosso foco de pesquisa, tem objetivo assegurar aos 
jovens em conflito com a lei, que se encontram em privação de liberdade, assistência, proteção, educação e formação profissional. Eles devem ser colocados em instituições ou locais diferentes (separados) dos adultos, devendo ser beneficiados por uma atenção especial no que diz respeito às suas necessidades e problemas próprios.

Por fim, a sexta parte ao tratar da investigação, planificação e formulação de políticas e avaliação mostra a necessidade de formulação de planos e de políticas eficazes, bem como de avaliações periódicas das tendências, problemas e as causas da delinquência e da criminalidade juvenis.

\section{v. Regras Mínimas das Nações Unidas para a Elaboração de Medidas não Privativas de Liberdade - Regras de Tóquio}

As Regras Mínimas das Nações Unidas para a Elaboração de Medidas não Privativas de Liberdade foram adotadas pela Assembleia Geral das Nações Unidas na sua resolução 45/110, de 14 de Dezembro de 1990.

Nelas a Assembleia se declara convicta de que as penas substitutivas da prisão constituem um meio eficaz de tratar os delinquentes no seio da coletividade (tanto para o delinquente quanto para a sociedade) e que o objetivo último da justiça penal é a reinserção social do delinquente.

Apesar de as regras serem específicas de penas não privativas de liberdade, interessante perceber os princípios ali elencados e determinadas convenções internacionais. As Regras Mínimas enunciam princípios básicos que visam favorecer o recurso a medidas não privativas de liberdade, assim como garantias mínimas para as pessoas submetidas a medidas substitutivas da prisão (regra 1.1), as quais devem ser privilegiadas a fim de reduzir o recurso às penas de prisão e racionalizar as políticas de justiça penal.

As medidas não privativas de liberdade devem ser aplicadas de acordo com o princípio da intervenção mínima (regra 2.6), devendo a escolha da medida ser fundada em critérios estabelecidos relativos tanto à natureza e gravidade da infração (regra 3.2), sua aplicação se faz no respeito pelo direito do delinquente e da sua família à vida privada (regra 3.11). A pena tem que ter em conta a necessidade de reinserção do delinquente, a proteção da sociedade e do interesse da vítima (regra 8), devendo sua aplicação diminuir os casos de reincidência e facilitar a reinserção do delinquente na sociedade. Os delinquentes devem receber uma assistência psicológica, social e 
material, devendo ser tomadas disposições para reforçar os seus laços com a comunidade e facilitar a sua reinserção na sociedade (regra 10.4).

Para isso, as condições das medidas não privativas de liberdade devem ser práticas e precisas e as pessoas que irão aplicar as medidas devem ser qualificadas e ter uma formação especializada apropriada e experiência prática (regra 16.1). A participação da coletividade também deve ser encorajada, pois constitui um importante meio de reforçar laços entre os delinquentes submetidos a medidas não privativas de liberdade e as suas famílias e a comunidade (regra 17.1).

Por fim, a investigação e planificação são necessárias, devendo ser integrados no sistema de justiça penal para recolher e analisar os dados estatísticos pertinentes sobre a aplicação do tratamento de delinquentes em meio aberto.

\section{vi. Regras mínimas para o tratamento de prisioneiros}

No âmbito internacional, a educação dos adultos encarcerados, é prevista no documento "Regras mínimas para o tratamento de prisioneiros", elaborado no $1^{\circ}$ Congresso das Nações Unidas sobre Prevenção do Crime e Tratamento de Delinquentes, realizado em Genebra, em 1955, aprovado pelo Conselho Econômico e Social da ONU por meio da sua resolução 663 C I (XXIV), de 31 de julho de 1957, e aditada pela resolução 2076 (LXII) de 13 de maio de 1977.

Tais regras buscam estabelecer princípios e normas de uma boa organização penitenciária e da prática relativa ao tratamento de prisioneiros. Eles tratam de matérias relativas à administração geral dos estabelecimentos penitenciários, sendo aplicável a todas as categorias de prisioneiros, criminais ou civis, em regime de prisão preventiva ou já condenados, incluindo aqueles que tenham sido objeto de medida de segurança ou de medida de reeducação ordenada por um juiz. Em que pese estas regras não estarem destinadas a determinar a organização de estabelecimentos para delinquentes juvenis (como estabelecimentos Borstal, instituições de reeducação, etc.), pode-se, de um modo geral, considerar que a primeira parte destas regras mínimas também é aplicável a esses estabelecimentos, por isso a importância destas para a presente pesquisa.

Insta frisar que as próprias regras dispõem que delinquentes juvenis não deveriam ser condenados a penas de prisão.

Como princípios fundamentais as regras devem ser aplicadas imparcialmente, não podendo haver discriminação alguma baseada em raça, cor, sexo, 
língua, religião, opinião política ou qualquer outra opinião, origem nacional ou social, fortuna, nascimento ou em qualquer outra situação. Outra necessidade que as regras impõe está na separação de categorias (Regra 8) já que as diferentes categorias de presos deverão ser mantidas em estabelecimentos prisionais separados ou em diferentes zonas de um mesmo estabelecimento prisional, levando-se em consideração seu sexo e idade, seus antecedentes, as razões da detenção e o tratamento que lhes deve ser aplicado. Tal regra nos remete a prevista no ECA e no SINASE no que concerne a fixação e aplicação da pena de privação de liberdade.

As regras tratam especificamente de diversas questões sensíveis a privação de liberdade, como o local destinado aos presos (Regra 9-14), a higiene pessoal (Regra 15-16), as roupas de vestir, camas e roupas de cama (Regra 17-19), a alimentação (Regra 20), a prática de exercícios físicos (Regra 21), o fornecimento de serviços médicos (Regra 22-26), as disciplina e sanções (Regra 27-32), os instrumentos de coação (Regra 33-34), a informação e direito de queixa dos presos (Regra 35 -36), a possibilidade de contato com o mundo exterior (Regra 37-39), a existência de biblioteca (Regra 40), a prática de religião (Regra 41-42), o depósito de objetos pertencentes aos presos (Regra 43), a notificação de morte, doenças e transferências (Regra 44), a transferência de presos (Regra 45), o pessoal penitenciário (Regra 46-54), e a inspeção (Regra 55).

A parte II, ao tratar das regras aplicáveis a categorias especiais, dispõe em seu item 77, denominado "Educação e recreio", que:

1. Serão tomadas medidas para melhorar a educação de todos os presos em condições de aproveitá-la, incluindo instrução religiosa nos países em que isso for possível. A educação de analfabetos e presos jovens será obrigatória, prestando-lhe a administração especial atenção. 2.Tanto quanto possível, a educação dos presos estará integrada ao sistema educacional do país, para que depois da sua libertação possam continuar, sem dificuldades, a sua educação.

Tal previsão, acaba por mencionar dentro da educação intramuros, do indicativo de qualidade, tão tratado no sistema educacional nacional.

\section{O fornecimento educacional do adolescente em conflito com a lei e a visão do}

\section{Judiciário}


Conforme já mencionamos, apesar das Constituições Liberais procurarem a “inação" estatal, a Revolução Industrial e o "movimento das coisas"273 passou a exigir mais ação estatal, sendo necessário um planejamento estratégico, no qual devem ser escolhidos fins e objetivos comuns, além dos instrumentos e meios para alcançá-los.

O Estado Contemporâneo, assim, passou a ter legitimidade e capacidade para realizar objetivos predeterminados, de modo que a reorganização da atividade estatal em função de finalidades coletivas torna-se indispensável, sendo atribuição dos Poderes Públicos propiciar condições básicas ao alcance da igualdade social. Esta passagem de modelos estatais, e necessidade de reorganização da atuação estatal em vista de da realização de finalidades coletivas, as quais devem ser concretizadas programadamente através de políticas públicas ou programas de ação governamental, de maneira coletiva, que englobe todos os Poderes/Funções estatais.

Assim, seguindo este novo modelo de Estado as Constituições do Estado Dirigente impõem objetivos ao corpo político, os quais devem orientar todo o funcionamento do Estado e organização da sociedade, tais quais os objetivos do art. $3^{\circ}$ da Carta Magna de 1988; Objetivos, estes, juridicamente vinculantes para todos os órgãos estatais, o que vem por quebrar o dogma do Estado Liberal da atividade legislativa preponderante sobre os demais poderes e o dogma da atividade jurisdicional "prestada por um juiz que representava apenas la bouche de la loi"274.

A professora GRINOVER relembra que "no Brasil, durante muito tempo os tribunais auto-limitaram-se, entendendo não poder adentrar o mérito do ato administrativo"275. Tendo a Lei da Ação Popular aberto ao Judiciário a possibilidade de apreciação do mérito do ato administrativo nos casos dos artigos $4^{\circ}, \mathrm{II}, \mathrm{b}, \mathrm{e} \mathrm{V}, \mathrm{b}$, da Lei n.4.717/65. A Constituição de 1988 acabou por ampliar o instituto, quando em seu artigo $5^{\circ}$, inciso LXXIII previu que

\footnotetext{
qualquer cidadão é parte legítima para propor ação popular que vise a anular ato lesivo ao patrimônio público ou de entidade de que o Estado participe, à moralidade administrativa, ao meio ambiente e ao patrimônio histórico e cultural, ficando o autor, salvo comprovada má-fé, isento de custas judiciais e do ônus da sucumbência.
}

\footnotetext{
${ }^{273}$ COMPARATO, Fábio Konder. Ensaio sobre o juízo de constitucionalidade de políticas públicas, in Revista dos Tribunais, Ano 86, V. 35, 1997, p. 16.

${ }^{274}$ GRINOVER, Ada Pellegrini. O controle de políticas públicas pelo Poder Judiciário. O processo: estudos e pareceres. $2^{a}$ edição revisada e ampliada. São Paulo: DPJ Editora, 2009. p. 38.

${ }^{275}$ GRINOVER, Ada Pellegrini. O controle de políticas públicas pelo Poder Judiciário. O processo: estudos e pareceres. $2^{a}$ edição revisada e ampliada. São Paulo: DPJ Editora, 2009. p. 37.
} 
Por sua vez, Cândido Dinamarco entende que foi a ação popular que abriu caminho ao Judiciário para o controle de mérito do ato discricionário do poder publico a partir do momento em que ela desmistificou o dogma da "substancial incensurabilidade do ato administrativo" 276 .

Como já mencionado anteriormente, a Constituição de 1988 fez mais ao fixar os objetivos fundamentais da República Federativa do Brasil em seu artigo $3^{\circ}$, pois para atingir tais objetivos (acrescendo-se a eles o princípio da prevalência dos direitos humanos, previsto no artigo $4^{\circ}$, II da CF) o Estado deve se organizar no facere e praestare, modificando a realidade social. Tanto que para Oswaldo Canela Jr. "cabe ao Poder Judiciário investigar o fundamentos de todos os atos estatais a partir dos objetivos fundamentais inseridos na Constituição (art. $3^{\circ}$ da CF brasileira)" ${ }^{, 277}$ havendo, portanto, a necessidade de uma postura do Judiciário mais ativa e comprometida socialmente.

Tanto que atualmente com os julgamentos do STF de casos complexos como o Raposa Serra do Sol e mesmo o Mensalão, vemos o Poder Judiciário cada vez mais na mídia, e a importância da considerável influência que este exerce sobre as políticas governamentais. Nessa direção confluem as conclusões de RAMOS:

O controle jurisdicional sobre os atos do Poder Público que apresentem consequências jurídicas realça, modernamente, a importância do Poder Judiciário, que , ao contrário do Poder 'invisível e nulo' imaginado por Montesquieu, exerce considerável influencia sobre as políticas governamentais, ao exigir que a sua execução respeite a legalidade vigente. Isso se torna ainda mais nítido quando se trata de verificar a conformidade de atos legislativos, ou normativos em geral, à Constituição. ${ }^{278}$

Vemos assim, que as políticas governamentais são judiciáveis, tendo o juízo de constitucionalidade o objetivo de confrontar as políticas governamentais, seus objetivos constitucionalmente vinculantes e as regras que estruturam seu desenvolvimento. Ada Pellegrini afirma ainda que "o controle de constitucionalidade das políticas públicas pelo Poder Judiciário, assim, não se faz sob o prisma da

\footnotetext{
${ }^{276}$ GRINOVER, Ada Pellegrini. O controle de políticas públicas pelo Poder Judiciário. O processo: estudos e pareceres. $2^{\mathrm{a}}$ edição revisada e ampliada. São Paulo: DPJ Editora, 2009. p. 38.

${ }^{277}$ CANELA, Oswaldo. Jr. In. GRINOVER, Ada Pellegrini. O controle de políticas públicas pelo Poder Judiciário. O processo: estudos e pareceres. $2^{\text {a }}$ edição revisada e ampliada. São Paulo: DPJ Editora, 2009. p. 39 .

${ }^{278}$ RAMOS, Elival da Silva. Controle de constitucionalidade no Brasil: perspectivas de evolução. São Paulo: Saraiva, 2010. p. 438-439.
} 
infringência frontal à Constituição pelos atos do Poder Público, mas também por intermédio do cotejo desses atos com os fins do Estado"279.

A inconstitucionalidade de uma política pública pode ocorrer em razão de sua finalidade ou em razão dos instrumentos escolhidos para a sua concretização. Ela pode ser tanto comissiva quanto omissiva, sendo os efeitos jurídicos de uma decisão que fulmina de inconstitucionalidade uma política pública atingiria todas as leis e atos normativos executórios (efeito ex nunc), sendo desejável que esta tivesse além deste efeito desconstitutivo, a natureza injuntiva ou mandamental.

Em relação ao controle de políticas públicas pelo Judiciário não podemos esquecer a advertência de DWORKIN de que o princípio democrático é igualmente, limitador das decisões políticas dos magistrados, de forma que ao passo em que contribuem para a realização da democracia, os juízes estão igualmente limitados por ela $^{280}$.

Conforme demonstram Ronald Dworkin e Jürgen Habermas, a jurisdição constitucional não atua, simplesmente, mediante critérios valorativos e sim, mediante critérios normativos, pautados pela Constituição, e que, na justa medida de sua origem democrática, refletem os valores dominantes na sociedade." 281

De igual posicionamento RAMOS, para quem "em face da textura aberta das normas-parâmetro utilizadas na avaliação da regularidade dos atos controlados, não pode o juiz constitucional perder de vista a liberdade de conformação que, nos limites admitidos pela própria Constituição, deve ser assegurada ao legislador" ${ }^{282}$.

Ele também nos recorda o quanto a dinâmica do processo político democrático está mais aberta à participação popular (através de consultas e audiências públicas, plebiscitos, etc.) vindo a afirmar que o Poder Legislativo tem, assim, asseguradas "melhores condições do que a qualquer órgão do Poder Judiciário no

\footnotetext{
${ }^{279}$ GRINOVER, Ada Pellegrini. O controle de políticas públicas pelo Poder Judiciário. O processo: estudos e pareceres. $2^{\mathrm{a}}$ edição revisada e ampliada. São Paulo: DPJ Editora, 2009. p. 37.

${ }^{280}$ CANELA. Oswaldo Jr. O controle Judicial de Políticas Públicas. 1 ${ }^{\mathrm{a}}$. Edição. São Paulo: Saraiva, 2011. p. 91.

${ }^{281}$ RAMOS, Elival da Silva. Controle de constitucionalidade no Brasil: perspectivas de evolução. São Paulo: Saraiva, 2010. p. 464.

${ }_{282}$ RAMOS, Elival da Silva. Controle de constitucionalidade no Brasil: perspectivas de evolução. São Paulo: Saraiva, 2010. p. 440-441.
} 
responder às necessidades sociais, acompanhando os ágeis e raramente uniformes movimentos pelos quais se expressam. ${ }^{283}$.

Cumpre também lembrarmos de que o âmbito da independência do Poder Judiciário, o princípio da inafastabilidade, afinal, "se toda e qualquer lesão, ou ameaça de lesão, a direito viabiliza o exercício do direito de ação $\left(\mathrm{CF}\right.$, art. $\left.5^{\circ}, \mathrm{XXXV}\right)$, não poderá o Poder Judiciário restringir o acesso das partes ao processo por fundamentos externos ao sistema do Direito Processual. Em sendo, independente, o Poder Judiciário vincula-se tão somente aos objetivos do Estado $\left(\mathrm{CF}\right.$, art. $\left.3^{\circ}\right)$, de tal forma que não poderá paralisar sua atividade por invocação do fator econômico"284.

Partindo do pressuposto de que a Constituição é sistêmica e seu conteúdo integrado, sempre que nos deparamos com tal alegação, devemos também nos recordar de outros princípios como a prevalência dos direitos humanos (art. $4^{\circ}$ II, da CF), a igualdade $\left(5^{\circ}\right.$, da $\left.\mathrm{CF}\right)$, a legalidade $\left(5^{\circ}\right.$, II, da $\mathrm{CF}$ ), entre outros, como os princípios setoriais da administração pública (art. 37, da CF), os quais acabam por mitigar qualquer aplicação rigorosa da Separação dos Poderes. Podemos, assim, dizer que a constante afirmação de que o Poder Judiciário não tem competência para julgar questões políticas, devido à divisão de Poderes, deve ser desde já rechaçada. Quanto às criticas feitas à Jurisdição Constitucional brasileira de que lhe são outorgados poderes, amplos e discricionários (a exemplo da manipulação dos efeitos da declaração de inconstitucionalidade e o efeito vinculante das decisões), da ingerência em relação aos limites postos a sua atuação, e a alegação da falta de legitimidade democrática do Poder Judiciário, visto a composição dos quadros de juízes, magistrados e Ministros, não ser eleita pelo povo, tal qual ocorre nos demais Poderes, tais criticas devem ser rechaçadas.

Em relação às alegações de discricionariedade e demasiado poder, o processo judicial em si, coloca diversas barreiras e métodos de controle para a decisão/sentença jurídica, tal qual a necessidade de fundamentação da sentença (exigência do art.93, IX da CF), o debate processual marcado pelo contraditório (que faz com que os mais diversos argumentos sejam apreciados em juízo), além do fato do Poder Judiciário ser contra majoritário, o que leva ao debate público direitos de

\footnotetext{
${ }^{283}$ RAMOS, Elival da Silva. Controle de constitucionalidade no Brasil: perspectivas de evolução. São Paulo: Saraiva, 2010. p. 440-441.

${ }^{284}$ CANELA. Oswaldo Jr. O controle Judicial de Políticas Públicas. $1^{\mathrm{a}}$. Edição. São Paulo: Saraiva, 2011. p. 92.
} 
minorias que na maioria das vezes não tem espaço nos processos políticos convencionais $^{285}$.

Já, com relação à alegação da falta de legitimidade político-democrática do Supremo Tribunal Federal, alegação estendida a órgãos menores do Judiciário, tal alegação mostra-se um tanto equivocada, não só devido à existência daquilo que chamamos legitimidade reflexa, visto a indicação dos Ministros ser realizada pelo Presidente da República e passar por aprovação no Senado. Cumpre transcrever o entendimento de Willian L. Reynolds que ao refutar o argumento majoritário para criticar a posição ativista do judiciário, diz:

o juiz não decida de acordo com a sua vontade, mas sim, conforme determinam as fontes de direito. Neste diapasão, o campo de atuação judicial seria muito mais restrito do que o do legislador. Ademais, os juízes não precisam agradar ninguém para obter o seu poder, que vem da imperatividade das decisões, sendo que o mesmo não ocorre com o legislativo. ${ }^{286}$

Concluímos, assim, pela legitimidade constitucional do Poder Judiciário, no que se refere à conformação ou aplicação de políticas públicas, sendo necessária a análise do atual posicionamento do Judiciário brasileiro e como este tem se posicionado no que se refere ao direito à educação dos jovens nos estabelecimentos de privação de liberdade e a oferta educacional a este grupo tão específico.

Realizada pesquisa jurisprudencial das demandas educacionais referentes ao espaço de privação de liberdade se dará a partir da vigência do Estatuto da Criança e do Adolescente, ano de $1991^{287}$, até o ano de 2011. Tal corte temporal, que abarca os 20 anos de vigência do ECA, se faz por o considerarmos um importante ordenador jurídico para a garantia e defesa dos direitos da infância e juventude. Insta salientar que tal delimitação temporal é necessária, pois abrange não só o tempo suficiente para a criação do aparato jurídico-educacional do sistema de proteção à criança e ao adolescente, mas também à mudança ocorrida com os 06 anos de implantação da Fundação CASA e seu novo modelo de intervenção em substituição ao antigo modelo vigente na FEBEM.

\footnotetext{
${ }^{285}$ SABINO. Marco Antonio da Costa. Quando o Judiciário Ultrapassa seus Limites Constitucionais e Institucionais - O Caso da Saúde. In: GRINOVER, Ada Pellegrini; WATANABE, Kazuo. O controle jurisdicional das políticas públicas. São Paulo: Forense, 2011, p. 353-386.

${ }^{286}$ REYNOLDS. Willian L. Judicial Process in a Nutshell. $2^{\text {nd }}$ edition. Maryland: West Group, 1991, pp. 143-154.

${ }^{287}$ Promulgado em julho de 1990, e publicado D.O.U. 16.7.1990 e retificado no D.O.U de 27.9.1990, entrando em vigor 90 (noventa) dias após sua publicação (art. 266 da Lei 8.069/90).
} 
A primeira etapa de pesquisa jurisprudencial, etapa formal, buscou coletar e sistematizar as decisões dentro dos seguintes tópicos: 1. Número do processo; 2. Natureza do recurso; 3. Data do julgamento; 4. Categorias; 5. Temas; 6. Origem: Comarca originária do processo; 7. Apelante/Recorrente: os nomes dos autores que recorreram da decisão anterior; 8. Apelados/Recorridos: os nomes dos autores que foram apelados ou recorridos para a solução do litígio; 9. Câmara: Sessão onde ocorreu o julgamento; 10. Votação: se unânime ou maioria dos votos; 11. Resultado: se o recurso foi provido, não provido, parcialmente provido, recurso extinto; 12. Relator: nome do desembargador relator da decisão; e 13. Localização da ementa e do acórdão: indicando a origem do acesso do material.

A análise se deu a partir da coleta de decisões nos sítios eletrônicos do STJ e STF, através do banco de dados "Pesquisa - Jurisprudência do STJ" e "Pesquisa de Jurisprudência" do STF, utilizando como descritores: "direito à educação", "educação", "privação de liberdade", "jovem", "socioeducativa", e "internação". No sítio eletrônico do STJ foram selecionados registros referentes à "educação, privação de liberdade, e socioeducativa", totalizando 04 decisões monocráticas, sendo três habeas corpus referentes a mudança de medida socioeducativa de internação para aberta e/ou semiliberdade, e um recurso especial para o mesmo fim, sendo os primeiros concedidos e o recurso negado.

Já no sítio eletrônico do STF não foram selecionados registros com base nos descritivos mencionados, de modo que inexistem decisões referentes ao fornecimento educacional nas prisões, apreciadas pelo Supremo Tribunal Federal.

O Tribunal de Justiça do estado de São Paulo, através do banco de dados "Magistrado", "Consulta Jurisprudência", utilizando como descritores: "direito à educação", “educação", “privação de liberdade”, “jovem”, “socioeducativa”, e "internação". No sítio eletrônico do TJ-SP foram selecionados registros referentes à “educação", "privação de liberdade" e "jovem”, totalizando 02 decisões monocráticas, aparecendo a mensagem de que haviam mais decisões, porem, estas se encontravam em segredo de justiça. Por sua vez utilizando os descritores "educação", "privação de liberdade" e "socioeducativa" não foi localizada nenhuma decisão.

Os registros encontrados não se referem direitamente a garantia do direito à educação na prisão, nem ao fornecimento educacional, mas sim a processos de execução da MSE, pedidos de modificação de MSE ou contra a inserção do adolescente em MSE de internação, como no caso dos pedidos de habeas corpus encontrados. 
Após a sistematização da jurisprudência (presente na parte anexos), a segunda etapa de análise (análise material), se dará através do roteiro de pesquisa apresentado nos objetivos da pesquisa. Sendo escolhida a decisão monocrática do habeas corpus $\mathrm{n}^{\mathrm{o}} \mathbf{2 2 4 . 5 8 3}$ - origem SP (2011/0269500-4) proferida em 30 de novembro de 2011, pelo relator do caso, o Ministro Sebastião Reis Júnior, cuja decisão concedeu a ordem de habeas corpus a fim de inserir adolescente em medida socioeducativa de liberdade assistida associada ao acompanhamento ambulatorial psiquiátrico, psicopedagógico e familiar.

\section{STJ: Decisão monocrática do habeas corpus no 224.583 - SP (2011/0269500-4)}

\section{a. Contexto}

A decisão analisada é referente habeas corpus impetrado em benefício de adolescente (S. D. A.), e aponta como autoridade coatora a Câmara Especial do Tribunal de Justiça de São Paulo, que denegou o pedido de Habeas Corpus, indeferindo a modificação da medida socioeducativa aplicada à adolescente, e mantendo-a na MSE de internação, não levando em conta relatório técnico que sugeria a progressão da medida e afirmando que tal relatório não o vinculava. A decisão do Magistrado de primeiro grau acaba por fundamentar-se, apenas, na existência de faltas disciplinares cometidas pela adolescente.

A adolescente já se encontrava internada há mais de 02 anos "em decorrência de sentença judicial que determinou sua internação, em razão da prática de ato infracional equiparado ao crime de tráfico de drogas", e apresentava distúrbio de conduta, com sintomas de autoflagelação, agressividade, alucinações visuais e auditivas, irritabilidade excessiva, dentre outros, que estavam se agravado em razão das condições ambientais (encarceramento), nas quais a adolescente estava inserida.

O HC pleiteou, ainda, que a adolescente fosse encaminhada "a um atendimento individual e especializado, compatível com sua limitação mental", suscitado o $\S 3^{\circ}$, do art. 112 do ECA e a colocação da jovem em liberdade, em medida proteção, sendo necessário o tratamento ambulatorial, psiquiátrico, psicopedagógico e familiar.

Os principais problemas suscitados são a finalidade da MSE de privação de liberdade, sua ineficácia, no caso da jovem, já que a privação de liberdade e falta de contato com a família estavam visivelmente definhando a jovem e lhe causando sérios 
problemas de ordem psicológica e afetiva. Tanto que o relator é claro ao dizer que o "intuito da medida socioeducativa, em qualquer de suas modalidades, é o de educação e ressocialização do menor infrator. Sua aplicação é realizada de acordo com o caso que se apresenta, sendo consideradas as circunstâncias da prática do ato infracional (objetivas) e as condições pessoais do menor infrator (subjetivas)". Ele ainda aventa que as reavaliações periódicas servem para que a efetividade da MSE imposta seja verificada.

A presença da família da jovem no acompanhamento da medida também é um problema (no caso solução) do qual a decisão trata. Isto porque no caso analisado, a mãe da jovem (Sra. A) participa de forma ativa nas ações propostas pela equipe de técnicos para reorganização pessoal de sua filha ${ }^{288}$. Tal participação só é possível dada a descentralização do sistema de atendimento e de cumprimento de medida socioeducativa, que é estadual, mas busca estabelecer convênios municipais para aproximar o adolescente da comunidade e auxiliá-lo no cumprimento da pena. Ocorre que o SINASE ainda é muito recente e ainda não é aplicado de forma integral, sendo um sério problema político-social.

Outro sério problema que podemos notar na decisão em questão é o fato da MSE não ter prazo definido, apenas a previsão de ser breve e não ultrapassar 03 anos. Tal falta de correspondência entre o ato infracional considerado crime e a quantidade de meses/anos para o cumprimento da medida (tal qual ocorre na execução penal do adulto), acaba por ampliar o poder discricionário do juiz que determina a MSE, que acaba infringindo aos adolescentes medidas muito mais duras do que aos adultos (resguardados pela legislação penal garantista). No presente caso a jovem está submetida a medida de internação há mais de 2 anos.

A utilização de terapia medicamentosa na MSE aparece no laudo que o magistrado transcreve, sendo uma preocupação a utilização de medicamentos no curso da internação, como forma de conter e/ou acalmar o jovem. Tanto que o tratamento médico não pode ser ministrado por funcionários que não possuam titulação e aptidão técnica para tal.

Por fim, o principal problema que visualizamos está no fato da própria medida socioeducativa proposta à adolescente, ser a de internação, esta, que deveria ser

288 "Nesse sentido, participa das consultas psiquiátricas de S. realizadas na rede de saúde de Tatuí/SP para aumentar sua percepção e responsabilidade sobre as vivências de sua e filha e sobre as perspectivas que visualizam para quando for encerrado o período de privação de liberdade" (habeas corpus n 224.583 - SP (2011/0269500-4). 
a ultima ratio, e que no presente caso, está claramente acentuando uma espécie de desgaste psíquico no contexto familiar e distanciando a jovem de pessoas afetivas e próximas de sua convivência, gerando sérios prejuízos a resignificação da adolescente e a organização da vida familiar.

A decisão ocorreu em novembro de 2011, ou seja, dentro de um contexto de ampliação dos direitos sociais, no qual além da Constituição de 88 (conhecida por Constituição Cidadã) prever e garantir direitos à todas as crianças e adolescentes, a legislação infraconstitucional como o ECA de 1990, as resoluções do CONAMA e os tratados internacionais dos quais o Brasil é signatário, são fonte extensa e robusta de legislação constitucional e ordinária, na defesa da proteção de crianças e adolescente. Porém da data da sentença, ainda não existia o SINASE, que esmiúça de modo mais claro o cumprimento da medida socioeducativa.

\section{b. Texto e significado da norma}

Os sentidos interpretativos que podem ser atribuídos ao enunciado são aqueles ligados a doutrina de proteção integral e prioridade absoluta da criança e do adolescente que vê a legislação de forma sistêmica e busca considerar o conjunto de normas como um todo.

\section{c. Controvérsias constitucionais}

As principais controvérsias suscitadas pela normatização estão no binômio punir educar da pena no direito penal juvenil, já que apesar da extensa legislação protetiva dos direitos da criança e do adolescente, o ato infracional ou conduta considerada crime, deve ser punido pelo Estado.

\section{d. Argumentacão das partes e dos envolvidos, se houver}

Infelizmente no presente caso, já em grau de recurso, não temos acesso as argumentações das partes envolvidas em primeiro grau, restando-nos apenas a decisão do Tribunal de Justiça do Estado de São Paulo, sob a qual foi impetrado o habeas corpus. Também não temos acesso ao parecer do Ministério Público Federal, que se posicionou a favor da concessão do HC.

\section{e. Argumentação do Tribunal}


A principal razão exposta na tese aplicada, já que por tratar-se de decisão monocrática, não temos votos dissidentes e outros posicionamentos além do relator, Ministro Sebastião Reis Júnior; é a de que nos termos do $\S 1^{\circ}$ do art. 112 do ECA, a imposição de medida socioeducativa deve considerar a capacidade de seu cumprimento pelo adolescente, no caso concreto e no caso em questão, a adolescente não possui capacidade mental para assimilar a medida socioeducativa, que, acaba revestindo-se de caráter retributivo e não ressocializador, sendo incompatível com os objetivos do ECA.

\section{f. Decisão do Tribunal}

A norma da decisão vai no sentido de conceder a ordem (HC) para “confirmar a liminar já deferida, inserindo a paciente na medida socioeducativa de liberdade assistida associada ao acompanhamento ambulatorial psiquiátrico, psicopedagógico e familiar".

Sendo esta motivada pelo fato de que os fundamentos contidos nas decisões impugnadas não afastam a conclusão do laudo técnico, no sentido de que a medida de internação, que já perdura por mais de 2 anos, não trazendo progresso à jovem, que não mais assimila os benefícios da medida aplicada, necessitando de tratamento ambulatorial, bem como o estreitamento dos seus vínculos familiares. Para isso, o relator se utiliza do ECA e a da Constituição Federal brasileira, no que concerne ao direito da criança e do adolescente e a aplicação de medida socioeducativa.

O resultado da decisão não é facilmente aceito na sociedade, devido o movimento que se faz para a mitigação de direitos humanos, principalmente quando tratamos dos jovens em conflito com a lei (que são na maioria das vezes pobres e periféricos). O atual estado de democracia disjuntiva, já mencionado em capítulos anteriores nos mostra o quanto o senso comum e o cidadão médio é refratário a garantia de direitos da juventude infracional.

O principal resultado final tem como benefícios sociais, não apenas a consolidação da legislação referente à proteção da criança e do adolescente, mas também a consolidação do estado Democrático de Direito. 


\section{CONSIDERAÇÕES FINAIS}

1. O Estado Brasileiro é um Estado Democrático de Direito, conforme o previsto no artigo $1^{\circ}$ da Constituição da República Federativa do Brasil de 1988, definição que leva em conta o poder exercido no Estado, e o princípio da necessidade de efetiva participação popular. O Estado, assim, se encontra diretamente associado aos princípios: república (supremacia do bem comum sobre os interesses individuais) e democracia (supremacia da vontade popular).

2. O Estado organizou-se para ser democrático, de modo que este e todas as teorias que informam as Constituições (formas de Estado e de governo) encontram-se elencadas nas cartas constitucionais que irão fundamentar e guiar as ações do Estado. Nas experiências históricas do Estado de Direito, a Constituição passou de mera fotografia do poder (modelo, em certa medida, do positivismo e do jusnaturalismo) para reflexo do "dever ser", sendo reconhecida sua força normativa, expandida sua jurisdição e aprimorada a dogmática de interpretação constitucional.

3. Todo esse movimento trouxe a tona um novo modelo de Estado (Estado Constitucional) que não é considerado como um fim em si mesmo, mas como um instrumento de garantias de direitos. Tanto que o conceito contemporâneo de Constituição reconhece o povo enquanto efetivo detentor do poder político, além de estabelecer os procedimentos de legitimidade do exercício deste poder (representantes eleitos; e titulares - povo); condicionar o exercício do poder político à realização dos direitos fundamentais; e ainda garantir a normatividade.

4. O Brasil, ao colocar os direitos do homem dentro do status de direitos constitucionais, acabou por condicionar não apenas o exercício do poder político, mas a própria realização desses direitos. Exercício que pode ser visto no disposto do artigo $5^{\circ}$ parágrafo $1^{\circ}$ da Constituição Federal de 1988, ao estabelecer que as normas definidoras dos direitos e garantias fundamentais têm aplicabilidade imediata.

Tal disposição encontra-se relacionada à ideia contemporânea de direitos humanos, enquanto universais, intransferíveis, imprescritíveis, indivisíveis, inalienáveis, irrenunciáveis, interdependentes entre si, tendo como objetivo a garantia da dignidade humana. Eles podem ser individuais, coletivos e difusos.

5. A garantia e efetivação dos direitos é condição necessária ao conceito de Estado Democrático de Direito. Por sua vez, o direito fundamental à educação é 
precursor dos demais direitos, uma vez que leva o individuo a desenvolver, com autonomia, as suas potencialidades como ser humano, além de ser um dos meios mais eficazes para se alcançar a dignidade da pessoa humana. De modo sintético, pode-se dizer que a Democracia e educação sempre andam juntas. O direito à educação também pode ser compreendido enquanto direito social, dimensão dos direitos fundamentais do homem, consistentes em prestações positivas proporcionadas pelo Estado.

6. O direito à educação comporta os vocábulos educação e ensino, porém apesar destes serem utilizados como equivalentes, possuem significados distintos, sendo a educação mais ampla que ensino. Educação envolve processos culturais, sociais, éticos, familiares, religiosos, ideológicos e políticos presentes ao longo da formação do indivíduo; ao passo que o ensino é mais pontual, se relacionando a um processo de aprendizado, direcionado e direto (formação elementar do indivíduo nas ciências, práticas e saberes constituídos pela humanidade).

Em que pese a Constituição Federal de 1988, a LDB (Lei 9.394, de 20 de dezembro de 1996) ou mesmo o ECA (Lei $\mathrm{n}^{\circ}$ 8.069, de 13 de julho de 1990), empregarem os vocábulos muitas vezes enquanto sinônimos, concluímos que o ensino é "um capítulo da educação de uma pessoa", mais ampla e por isso relacionada aos diferentes processos socioculturais que formam o indivíduo.

7. A educação fortalece os liames éticos, dignifica o cidadão, amplia seus horizontes e suas opções intelectuais, morais, sociais, cívicas e laborais. Ela alavanca o cidadão para o desenvolvimento; motivos por si só suficientes para a criação de medidas efetivas que permitam a todos o acesso e a manutenção à/da educação. No concernente ao ensino público, este deve ser acessível a todos, de qualidade, e investir nos professores, em programas suplementares (alimentação, material escolar e transporte). Sendo a igualdade de oportunidades e a garantia de vagas para todos, condições de realização do ensino público no Brasil.

8. A garantia de implementação e acesso à educação, mais do que um direito fundamental, é uma obrigação estatal e questão de política pública, principalmente quando tratamos da oferta educacional para aqueles que estão em fase de desenvolvimento como as crianças e os adolescentes. Ela abrange tanto o atendimento a crianças em idade escolar (2-18 anos) em creches, pré-escolas e ensino fundamental, quanto àqueles que não tiveram acesso à educação na idade própria.

9. Dentre as fontes do Direito Educacional temos a Constituição da República Federativa do Brasil (artigos $6^{\circ}$ e 205 e seguintes da Constituição Federal), 
que tem como objetivos o pleno desenvolvimento da pessoa; seu preparo para o exercício da cidadania; e sua qualificação para o trabalho; a lei n. 9.394, de 20.12.96, Lei de Diretrizes e Bases da Educação Nacional, que regulamenta as linhas traçadas pela Constituição Federal, disciplina a educação escolar, define incumbências como jurisdição e forma de relacionamento dos Sistemas de Ensino; o Plano Nacional de Educação, que deve ser fruto de debate dos representantes dos diversos partidos políticos, entidades e órgãos educacionais; bem como Conselho Nacional de Educação e outros órgãos relacionados ao tema.

Por sua vez, no âmbito internacional, inúmeros tratados e declarações tratam do direito à educação, sua promoção e garantia; sendo as principais a Declaração Universal dos Direitos Humanos, o Pacto Internacional dos Direitos Econômicos, Sociais e Culturais (PIDESC), a Declaração de Hamburgo, a Declaração Mundial sobre Educação para todos.

10. A garantia e efetivação de direitos sociais, ditos prestacionais, necessita de programas de ação, planejamento e investimento, consolidados através de políticas públicas, no presente estudo, políticas públicas educacionais. Política pública enquanto programa de ação, quadro de ação governamental, que permite a adoção de medidas articuladas no sentido de concretizar um direito. Tais medidas perpassam por todas as funções do Estado: Legislativa, Executiva e Judiciária; uma vez que todas estão ligadas aos fins do Estado (art. $3^{\circ}$ da CF).

Destarte, a atuação do Poder Judiciário na efetivação de direitos fundamentais, a partir do seu juízo de constitucionalidade de políticas públicas, é cabível e em alguns casos necessária. Tanto que a jurisprudência ampla e na maioria das vezes progressista, quando se trata do direito à educação; elevando-o ao patamar de direito fundamental e entendendo ser de aplicabilidade imediata, principalmente por envolver a garantia de um direito primordial, prestado especialmente às crianças e adolescentes.

11. O direito da criança e do adolescente é recente, visto que a infância apenas passou a ser identificada no tecido social brasileiro no final do século XVII e início do século XVIII, tendo seu período de maior destaque no século XX com o avanço do positivismo e da doutrina menorista.

Durante este período crianças e adolescentes pobres e desvalidos ou autores de infração (binômio criança carente/delinquente) recebiam o mesmo tratamento do Estado, passando a ser objeto da atenção de médicos, psicólogos e juristas, 
institucionalizados em casas públicas de custódia, nas quais o modelo compaixãorepressão era aplicado.

12. Esta realidade somente foi superada com a proteção especial trazida pela Constituição Federal de 1988 e legislação infraconstitucional que alicerçaram os direitos da criança e do adolescente, configurando o Sistema Constitucional Especial de Proteção. Sistema que deriva do disposto nos artigos 226, 227, 228 e 229 da Constituição Federal, tendo nos princípios da prioridade absoluta, da tutela diferenciada e da igualdade seu alicerce principiológico.

Conforme vimos ao longo do trabalho, a proteção especial e o tratamento diferenciado se dão a partir do pressuposto de que crianças e adolescentes são seres vulneráveis e em formação, necessitando de tratamento especial por parte do legislador. A Constituição não distingue, assim, os direitos fundamentais da criança e adolescente em classes, estando todos no rol de direitos do seu artigo 227, devendo o Estado adotar uma postura ativa em relação a esses direitos.

13. O tratamento diferenciado dispensado às crianças e adolescentes engloba, assim, a Doutrina do Respeito à Peculiar Condição de Pessoa em Desenvolvimento (uma vez que eles se encontram em processo formação física, psíquica, moral, etc., demandando proteção jurídica especial e o reconhecimento de direitos especiais, permitindo-lhes construir suas potencialidades e desenvolver sua personalidade para a vida adulta); a Doutrina da Prioridade Absoluta (na qual Estado, sociedade e família devem assegurar o direito à vida, à saúde, à alimentação, à educação, ao lazer, à profissionalização, à cultura, à dignidade, ao respeito, à liberdade e à convivência familiar e comunitária das crianças e adolescentes, com prioridade absoluta); e a Doutrina da Proteção Integral (devendo os direitos fundamentais das crianças e dos adolescentes receber proteção integral).

14. Concluímos que a Constituição Federal, ao priorizar a efetivação dos direitos fundamentais das crianças e adolescentes, fez mais do que fixar os direitos individuais e sociais, pois para serem efetivados o Estado e os órgãos públicos, privados e entidades da sociedade civil devem ter uma postura ativa e comprometida socialmente. De tal modo que a rede para a manutenção e promoção do sistema especial de proteção aos direitos fundamentais das crianças é imensa, sendo a Política Nacional dos Direitos Humanos de Crianças e Adolescentes e o Plano Decenal dos Direitos Humanos de Crianças e Adolescentes construídos conjuntamente pelo Conselho 
Nacional dos Direitos da Criança e do Adolescente (Conanda), e a Secretaria de Direitos Humanos (SDH), da Presidência da República.

15. Quando tratamos da criança e do adolescente em conflito com a lei, a legislação protetiva permanece, mas a justificação social de tal proteção torna-se conflituosa, sendo muitas vezes proteção e imputabilidade confundidas por impunidade, havendo grande clamor público por medidas punitivas mais duras, e a crença de que o adolescente que comete ato considerado crime não responde por seus atos.

Tal discurso distorce o disposto no Sistema Constitucional especial de proteção aos direitos fundamentais da criança e do adolescente, confundindo imputabilidade penal com impunidade. Afinal, o adolescente que comete ato considerado crime responde por ele, sendo previstas diversas medidas socioeducativas (artigos 103, 104 e 212 do Estatuto da Criança e do Adolescente.), havendo até a previsão de internação em estabelecimentos prisionais (privação da liberdade).

16. Enfatizamos que adolescente em conflito com a lei é punido através das diversas medidas socioeducativas previstas no ECA, sendo a de internação em estabelecimentos prisionais uma das mais duras. Aos adolescentes sob custódia do Estado são garantidos os direitos abrigados no ECA e no SINASE, além de toda a legislação protetiva prevista nacional e internacionalmente.

Quando analisamos o perfil do adolescente em conflito com a lei, este possui idade média de 16,7 anos, cumprindo medida de internação por atos infracionais correspondentes a crimes contra o patrimônio (roubo, furto, entre outros), possuem elevada taxa de reincidência e baixa escolaridade.

Analisando dados do relatório apresentado pelo CNJ, em 2012, sobre a internação na Fundação CASA de São Paulo, chegamos a um perfil de jovens cujas famílias desestruturadas, a defasagem escolar e/ou a utilização de substâncias psicoativas, somadas a uma latente exclusão social, cultural e econômica potencializam a delinquência, sendo na maioria das vezes apontadas como causadoras do ato infracional e/ou envolvimento criminal.

17. Concluímos pela responsabilidade estrutural da sociedade, que exclui social, cultural e economicamente estes adolescentes em situação de conflito. $\mathrm{O}$ grande número de crimes contra o patrimônio nos leva a inferir o desejo de inclusão em uma sociedade capitalista, que exclui pelo consumo.

18. As medidas socioeducativas tem seu significado material relacionado à sua essência, o "ser" de seu objeto, elementos informadores a unilateralidade e a 
obrigatoriedade. Este, caráter sancionatório das MSEs faz com que elas sejam aplicadas excepcionalmente (excepcionalidade), dentro da lei e da normativa do sistema de proteção da criança e do adolescente (legalidade), bem como em curtos espaços de tempo (brevidade).

A importância do potencial instrumentalizador de mudanças da MSE está na sua finalidade pedagógica. Tanto executor quanto o aplicador estão vinculados aos seus critérios, princípios e garantias e finalidades, devendo a autoridade judiciária levar em conta obrigatoriamente as necessidades pedagógicas.

19. A busca de uma pedagogia especificamente destinada ao adolescente autor de ato infracional constitui-se em desafio permanente dos operadores do sistema de atendimento e operadores responsáveis pela execução das medidas. O projeto político-pedagógico da MSEs deve visar fazê-los experimentar respostas e construir novas alternativas, devendo estimular a flexibilidade, valorizar o vivencial, respeitar o diferente.

Estudos nos mostram que muitas vezes o ato infracional deriva da busca por inclusão e reconhecimento, já que estes jovens não vivenciam situações que promovam seu desenvolvimento enquanto ser humano.

20. O sistema de cumprimento de medida socioeducativa de internação foi recentemente regulamentado pela lei $\mathrm{n}^{\mathrm{o}}$. 12.594, de 18 de janeiro de 2012, que busca concretizar a comunidade socioeducativa através da gestão participativa, realização de diagnóstico situacional dinâmico e permanente do programa de atendimento, realização de assembleias, criação de comissões temáticas ou grupos de trabalho, de rede externa, de um projeto pedagógico e de uma rotina da unidade e/ou programa de atendimento.

A ação socioeducativa deve respeitar as fases de desenvolvimento do adolescente através do Plano Individual de Atendimento (PIA) que é elaborado a partir da acolhida do adolescente com a realização de um diagnóstico polidimensional nas áreas jurídica, de saúde, psicológica, social e pedagógica, o qual irá embasar as metas e compromissos do plano individual.

21. O plano socioedutavivo contará com a educação formal, escolarização que se dá através de diversos projetos conforme o tipo de MSE de privação de liberdade que o jovem cumpre; sendo multiseriada (ou disseriada) e com currículo diferenciado, visto o caráter transitório de permanência de alguns alunos na unidade de internação. Ainda assim, são adotadas as Propostas Curriculares dos Cursos de Ensino Fundamental e Médio regulares da Rede de Ensino Estadual. 
Contará igualmente com a educação socioeducativa que consiste em práticas educativas orientadas para a cidadania, direitos humanos, valores, participação política e protagonismo, que instrumentalize o indivíduo para mudar as estruturas sociais que o vulnerabiliza. Para isto a educação deve ser vinculada à família, à comunidade, à cultura, ou seja, a seu contexto social entendido de maneira ampla.

A educação deve ser, assim, global, social e se dar até o resto da vida, capacitando o indivíduo a viver em sociedade e comunicar-se, necessitando para isso, uma relação de abertura, reciprocidade e compromisso.

22. A educação dentro de estabelecimentos de privação de liberdade deve se dar de maneira ampla e irrestrita, buscando resignificar o adolescente em conflito com a lei. Em que pese a legislação infraconstitucional de proteção a criança e ao adolescente ter mais de 22 anos, e a Lei de Diretrizes e Bases da Educação Nacional ter 16 anos, o SINASE, que regulamenta a o atendimento socioeducativo tem pouco mais de 1 ano.

Assim, a dado o fato das políticas governamentais serem judiciáveis, a partir do juízo de constitucionalidade, a pesquisa jurisprudencial realizada buscou verificar demandas educacionais referentes ao espaço de privação de liberdade. Para isso foram consultados os sítios eletrônicos do STF - no qual não foram selecionados registros jurisprudenciais, e do STJ, onde os registros encontrados não se referiam direitamente a garantia do direito à educação em estabelecimentos de privação de liberdade.

Dentre as decisões encontradas pudemos perceber o quanto os tribunais de primeira instância ainda não aplicam adequadamente os preceitos do ECA e da legislação protetiva da criança e do adolescente, negando ordens de habeas corpus, dificultando a inserção do adolescente em medida socioeducativa de liberdade assistida associada a acompanhamento (ambulatorial psiquiátrico, psicopedagógico e familiar), distanciam o jovem da família, além de não se utilizarem do laudo técnico e aplicarem medidas muito mais penosas do que as regulamentadas no direito penal.

23. Tendo a Constituição como conjunto sistêmico de conteúdo integrado, e acreditando que todas as funções/poderes do Estado encontram-se vinculados aos objetivos fundamentais do Estado Brasileiro, constantes no artigo $3^{\circ}$, sendo o Judiciário legitimado constitucionalmente na conformação ou aplicação de políticas públicas educacionais. Como a pesquisa jurisprudencial realizada não obteve êxito em encontrar decisões referentes ao tema, sendo poucas as decisões que tratavam da execução da MSE, fomos levados a questionar se a demanda educacional nos ambientes de privação de liberdade não aparece na jurisprudência nacional por não haver demanda, pelo fato 
do fornecimento educacional estar se dando conforme os parâmetros legais; pela falta de acesso desta população ao Judiciário ou porque as formas de controle judicial inicial acabam impedindo que tais demandas cheguem aos Tribunais Superiores, questionamentos estes, não abordados no presente trabalho, necessitando de pesquisas posteriores que elucidem essas questões.

24. Diante dessas constatações, é forçoso concluir que, ante as finalidades da MSE de resignificar o jovem em conflito com a lei e romper com a lógica de violência e deslocamento social que este vivenciou e vivencia extramuros, e a realizada dos jovens internados, ainda existe um grande abismo.

Mais do que escolarização, a educação dentro destes espaços deve ser emancipadora, resignificadora e inclusiva, procurando fornecer a este jovem excluído socialmente, instrumentos de luta, como capacidade de autodeterminação e de argumentação, e senso crítico, que o permitam novamente realizar um deslocamento do infracional, da violência, para o diálogo e a inclusão social. A educação deve também, ser organizada de modo a atender às peculiaridades de tempo, espaço e rotatividade deste grupo de indivíduos, buscando contemplar o atendimento em todos os turnos, propiciando espaços físicos adequados às atividades educacionais, esportivas, culturais, de formação profissional e de lazer.

25. A medida socioeducativa de internação só demonstrará esta eficácia, quando deixar de se limitar ao seu caráter eminentemente punitivo, que busca responsabilizar o adolescente pelas consequências lesivas do ato infracional (de perceptível a semelhança com a pena criminal), e passar a ser verdadeiramente educativa, visando processos internos e externos de aprendizagem e de resignificação, mais do que resocialização.

Em conclusão, a lógica da educação não se coaduna à lógica da punição dos estabelecimentos de privação de liberdade, de modo que se deve buscar fomentar a discussão sobre o direito à educação e seu fornecimento nos espaços de privação de liberdade, não apenas no meio acadêmico, mas principalmente entre aqueles que aplicam a lei e acompanham a execução da medida socioeducativa.

26. A discussão sobre o fornecimento educacional dos estabelecimentos prisionais ainda é muito incipiente, havendo inúmeros outros aspectos ainda a serem abordados tais quais: como articular educação com ausência de liberdade; quais os pontos de intersecção entre a educação formal e a não-formal, dentre as garantias processuais asseguradas ao adolescente privado de liberdade, como implantá-las e 
garanti-las efetivamente; quais os caminhos e práticas adequados para que a MSE de internação se constitua exclusivamente como medida punitiva; qual o perfil e a formação dos trabalhadores da área, qual o perfil do juiz executor de MSE na vara da infância e juventude.

Espera-se que este estudo estimule futuras investigações no campo do direito e demais áreas relacionadas ao tema. 


\section{REFERÊNCIAS BIBLIOGRÁFICAS}

Código Mello Matos, Decreto $\mathrm{n}^{\circ}$ 17.943-A, de 12 de outubro de 1927.

BRASIL. Constituição da República Federativa do Brasil. Brasília: Senado Federal, Centro Gráfico. 1988.

Declaração Universal dos Direitos Humanos. Adotada e proclamada pela resolução A (III) da Assembleia Geral das Nações Unidas em 10 de dezembro de 1948. Estatuto da Criança e do Adolescente. Lei nº. 8.069, de 13 de julho de 1990. . Lei de Diretrizes e Bases da Educação Nacional n. 9.394, de 20 de dez. 1996. . Parâmetros Curriculares Nacionais. Brasília: MEC, 1998. . CONSTITUIÇÃO DA REPÚBLICA FEDERATIVA DO BRASIL (1988). . Decreto n ${ }^{\circ} 17.943-A$ de 12 de outubro de 1927.

ALEXY, Robert. Teoria dos Direitos Fundamentais, trad. De Virgílio Afonso da Silva. São Paulo: Malheiros Editores, 2011.

ANGIEUSKI, Plínio Neves. Evolução dos Direitos Humanos: Crítica à Classificação em Gerações de Direitos. Boletim Jurídico. Edição no 138. Código da publicação: 745 ANIYAR DE CASTRO, Lola. La educación como forma de control social. Capítulo Criminológico: Revista de las Disciplinas del Control Social, Maracaibo, 11/12, p.35$51,1983 / 1984$.

APPOLINÁRIO, Fábio. Metodologia da Ciência: filosofia e prática da pesquisa. São Paulo: Pioneira Thomson Learning, 2006.

AMARO, Sarita. Crianças vítimas da violência: das sombras do sofrimento à genealogia da resistência. Uma nova teoria científica. Porto Alegre: AGE/EDIPURS, 2003.

BASTOS, Celso Ribeiro; MARTINS, Ives Gandra da Silva. Comentários à Constituição do Brasil. 2. ed. São Paulo: Saraiva, 1988. V.1.

BITTAR, Eduardo Carlos Bianca. Educação e metodologia para os direitos humanos. São Paulo: Quartier Latin, 2008.

Eduardo Carlos Bianca; GOIFMAN, Kiko. Educação, cultura e direitos humanos. São Paulo: ANDHEP, 2008. 2 v.

BOAVENTURA. M Edivaldo. A Educação na Constituição de 1988. Revista de Informação Legislativa. Brasília. Ano. 29, N. 116. Outubro a dezembro de 1992. 
Aspectos Juspedagógicos da Educação. Revista de Direito Constitucional e

Internacional. Cadernos de Direito Constitucional e Ciência Política. IBDC. Editora Revista dos Tribunais. Ano 13. Abril-Junho. N. 51. 2005.

. Um ensaio de sistematização do direito educacional. Revista de Informação

Legislativa. Brasília. Ano. 33, N. 131. Julho a setembro de 1996.

BOBBIO, Norberto. Liberalismo e Democracia. Tradução brasileira de Marco Aurélio Nogueira. $2^{\text {a }}$ edição. Rio de Janeiro: Paz e Terra, 1988.

Teoria geral do direito. $3^{\text {a }}$ edição. São Paulo: Martins Fontes, 2010. (Justiça e direito).

BUCCI, Maria Paula Dallari (org.) Políticas Públicas: Reflexões sobre o conceito Jurídico. São Paulo: Saraiva, 2006.

BUFFA. Ester. Educação e cidadania. Quem educa o cidadão? Coleção Questões da nossa época. $6^{\text {a }}$ edição. São Paulo: Cortez Editora, 1996.

BULHÕES, Antônio Nabor Areias. "Depoimento na audiência pública sobre redução da maioridade penal de 18 para 16 anos, realizada em 10/11/1999”. In: A razão da idade: mitos e verdades. $1^{a}$ Edição. Coleção Garantias de Direitos. Série Subsídios Tomo VII. Brasília: MJ/SEDH/DCA, 2001.

CALDEIRA, Teresa P. do Rio. Cidade de Muros: Crime, Segregação e Cidadania em São Paulo. São Paulo: Editora 34/Edusp, 2000.

CANELA, Oswaldo Jr. O controle Judicial de Políticas Públicas. 1ª Edição. São Paulo: Saraiva, 2011.

CANELA, Oswaldo. Jr. A efetivação dos direitos fundamentais através do processo coletivo: um novo modelo de jurisdição (tese de doutorado apresentada na USP sob orientação de Kazuo Watanabe).

CARNELUTTI, Francesco. A arte do direito. Campinas: Edicamp, 2003.

CARRAZZA, Roque Antonio. Curso de direito constitucional tributário. $3^{\text {a }}$ edição. São Paulo: RT, 1991.

CASTRO, Jorge Abrahão de; AQUINO, Luseni Maria C. de; e ANDRADE, Carla Coelho de (Org). Juventude e políticas sociais no Brasil. Brasília: Ipea, 2009.

CERQUEIRA, Thales tácito Pontes Luz de Pádua. Manual do estatuto da criança e do adolescente (teoria e prática). $2^{\mathrm{a}}$ Ed. Niterói, RJ: Impetus, 2010.

COMPARATO, Fábio Konder. A afirmação histórica dos Direitos Humanos. $7^{\mathrm{a}}$. Edição. São Paulo: Saraiva, 2010. 
. Ensaio sobre o juízo de constitucionalidade de políticas públicas, in Revista dos Tribunais, Ano 86, V. 35, 1997.

CONSELHO NACIONAL DE JUVENTUDE, Panorama Nacional. A Execução das

Medidas Socioeducativas de Internação Programa Justiça ao Jovem. CNJ, 2012.

COSTA, José Haroldo Teixeira da. "Reduzir a idade penal não é a solução". In: A razão da idade: mitos e verdades. $1^{\mathrm{a}}$ Edição. Coleção Garantias de Direitos. Série Subsídios Tomo VII. Brasília: MJ/ SEDH/DCA, 2001.

CUNHA JUNIOR, Dirley da. Controle Judicial das Omissões do Poder Público: Em busca de uma dogmática constitucional transformadora à luz do direito fundamental à efetivação da Constituição. São Paulo: Saraiva, 2004.

CUNHA, Luiz Antonio. Reflexões sobre as condições sociais de produção da sociologia da educação: primeiras aproximações. Tempo Social: Revista de sociologia da USP, São Paulo, v. 4, 1-2, p.169-182, 1992.

CUPIS, Adriano de. Os direitos da personalidade, Lisboa, Morais, 1961.

CURY, Carlos Roberto Jamil. A Constituição de Weimar: um capítulo para a educação. Educação e Sociedade, v.19, n. 63, ago, 1998.

CURY, Munir (Coord.), Estatuto da Criança e do Adolescente Comentado Comentários Jurídicos e Sociais, São Paulo: Malheiros, 2008.

DALLARI, Dalmo de Abreu. “A razão para manter a maioridade penal aos 18 anos". In: A razão da idade: mitos e verdades. $1^{\text {a }}$ Edição. Coleção Garantias de Direitos. Série Subsídios Tomo VII. Brasília: MJ/SEDH/DCA, 2001.

. Elementos de teoria geral do Estado, 26.ed., São Paulo: Saraiva, 2007.

. O futuro do Estado, São Paulo: Saraiva, 2002.

DÁVILA BALSERA, Paulí. El problema vasco en educación: conflicto y control de la enseñanza en el País Vasco. Poder y control: revista hispano-latinoamericana de disciplinas sobre el control social, Barcelona, n. 1, p.43-52, 1988.

DEBARBIEUX, Éric. Les enquêtes de victimation en milieu scolaire: leçons critiques et innovations méthodologiques. Déviance et Société, Louvain-la-Neuve, v. 28, n. 3, p.317-332, set. 2004.

ESPINOZA, Olga. A mulher encarcerada em face do poder punitivo. São Paulo: IBCCrim, 2004.

ESTERLE-HEDIBEL, Maryse. Absentéisme, déscolarisation, décrochage scolaire, les apports des recherches récentes. Déviance et Société, Louvain-la-Neuve, v. 30, n. 1, p.41-64, mar. 2006. 
FACHIN, Zulmar (Coord.). Direitos fundamentais e cidadania. São Paulo: Método, 2008.

FÁVERO, Osmar (org.). A educação nas constituintes brasileiras - 1823-1988. Campinas: Autores Associados, 1996.

FERRAJOLI, Luigi. Direito e Razão: teoria do Garantismo Penal. São Paulo: Revista dos Tribunais, 2002.

FERREIRA FILHO, Manoel Gonçalves. Comentários à Constituição Brasileira de 1988. V.1. São Paulo: Saraiva, 1990.

FERREIRA, Dâmares (Coord.) Direito Educacional em Debate - Vol. 1. São Paulo: Cobra Editora, 2004.

FOUCAULT, Michel. Vigiar e punir: nascimento da prisão. História da violência nas prisões. 35 a edição, tradução de Raquel Ramalhete. Petrópolis, RJ: Vozes, 2008.

FREGOSO, Heleno Cláudio. In: Lições de direito penal - a nova parte especial. Rio de Janeiro, Forense, $11^{\text {a }}$ Ed. p. 1-2, 1987 apud MACHADO, Martha de Toledo. A proteção constitucional de crianças e adolescentes e os direitos humanos. São Paulo: Manole, 2003.

FREIRE, Paulo. Pedagogia do oprimido, 17ª ed. Rio de Janeiro, Paz e Terra, 1987. Política e educação: ensaios / Paulo Freire. - 5. ed - São Paulo, Cortez, 2001 (Coleção Questões de Nossa Época; v.23)

FREITAS, Marcos Cezar de (org.). História social da Infância no Brasil. 5a .ed. - São Paulo: Cortez, 2003.

GARCIA, Emerson. O direito à educação e suas perspectivas de efetividade. Revista da EMERJ, Rio de Janeiro, v. 8, n. 32, p.223-271, 2005.

GARCIA. Maria. Mas, quais são os direitos fundamentais? Revista de Direito Constitucional e Internacional. IBDC. Editora Revista dos Tribunais, ano 10, abril/jun., n. 39, 2002.

GONÇALVES, Petronilha Beatriz e Silva, Silvério, Roberto, Valter. (Organizadores) Educação e ações afirmativas: entre a injustiça simbólica e a injustiça econômica. Brasília: Instituto Nacional de Estudos e Pesquisas Educacionais Anísio Teixeira, 2003. GONZÁLEZ ZORRILLA, Carlos. Para qué sirve la criminologia? nuevas aportaciones al debate sobre sus funciones. Revista Brasileira de Ciências Criminais, São Paulo, v. 2, n. 6, p.7-25, abr./jun. 1994. 
GRACIANI, Maria Stela Santos. "Os desafios da implantação das medidas socioeducativas no Brasil”. In: A razão da idade: mitos e verdades. $1^{\text {a }}$ Edição. Coleção Garantias de Direitos. Série Subsídios Tomo VII. Brasília: MJ/SEDH/DCA, 2001. GRINOVER, Ada Pellegrini. O controle de políticas públicas pelo Poder Judiciário. $O$ processo: estudos e pareceres. $2^{\text {a }}$ edição revisada e ampliada. São Paulo: DPJ Editora, 2009.

GRINOVER, Ada Pellegrini; WATANABE, Kazuo. $O$ controle jurisdicional das políticas públicas. São Paulo: Forense, 2011.

GUARÁ, Isa M. F. da Rosa (2000). O crime não compensa, mas não admite falhas: padrões morais de jovens autores de infração. Doutorado em Serviço Social. São Paulo: PUC-SP.

HADDAD, Sérgio, GRACIANO, Mariângela. (Organizadores) A educação entre os direitos humanos. Campinas, SP: Autores Associados; São Paulo: Ação Educativa, 2006.

HOLlANDA, Aurélio Buarque. Novo Dicionário. 1. ed. (5.reimpressão). Rio de janeiro, Nova Fronteira, s/d.

http://www.cidh.oas.org/annualrep/2002port/brasil12328.htm - Acesso em 10.10.2012.

http://www.seade.gov.br/produtos/ivj - Acesso em 04.02.2012.

IHERING, R. Von. A luta pelo Direito. Rio de Janeiro, Editora Rio, 1980.

JACOB, Cesar Augusto Alckmin. A "Reserva do Possível”: obrigação de previsão orçamentária e de aplicação da verba.

JAGUARIBE, H. Brasil, sociedade democrática. Rio de Janeiro. José Olímpio, 1985.

JULIÃO, Elionaldo Fernandes; SANTA RITA, Rosangela Peixoto. Rede latinoamericana de educação em espaços de privação de liberdade: uma estratégia de intercâmbio e consolidação de políticas públicas para a execução penal. Revista do Conselho Nacional de Política Criminal e Penitenciária, Brasília, v. 1, n. 21, p.29-48, 2008 .

KONZEN, Afonso Armando. Pertinência Socioeducativa. Reflexões sobre a natureza jurídica das medidas. Porto Alegre: Livraria do Advogado Ed., 2005.

LAFER, Celso. A internacionalização dos Direitos Humanos. São Paulo: Manole, 2005. A reconstrução dos direitos humanos: um diálogo com o pensamento de Hannah Arendt. São Paulo: Companhia das Letras, 1988.

LASKI, Harold J. O liberalismo europeu. São Paulo: Mestre Jou, 1973. 
LASLETT, Peter. A teoria social e política dos dois tratados sobre o governo. In: QUIRINO, Célia Galvão \& SOUZA, Maria Tereza Sadak R. de (Orgs.). O pensamento político clássico.

LASSALE, Ferdinand. Que é uma Constituição? São Paulo: Edições e Publicações Brasil, 1933.

LIBERATI, Wilson Donizeti (org.). Direito à educação: Uma questão de justiça. São Paulo: Malheiros, 2004.

Comentários ao estatuto da Criança e do Adolescente. 11ª ed. São Paulo: Melheiros Editores, 2010.

LIMA, Maria Cristina de Brito. A educação como direito fundamental. Revista da EMERJ, Rio de Janeiro, v. 4, n. 13, p.212-233, 2001.

LOCKE, John. O segundo tratado sobre o governo. São Paulo: Ibrasa, 1963.

MACHADO, Martha de Toledo. "Direito da Infância e Juventude". In: NUNES Jr., Vidal Serrano (Coord). Manual de Direitos Difusos. São Paulo: Editora Verbatim, 2009. A proteção constitucional de crianças e adolescentes e os direitos humanos. São Paulo: Manole, 2003.

MAGNOLI, Demétrio (org.). História da paz: os tratados que desenharam o planeta. São Paulo: Contexto, 2008. Vários Autores.

MALUF, Sahid. Teoria geral do Estado. 23ª .edição, revisada e atualizada. São Paulo: Saraiva, 1995.

MONTORO, André Franco Jr. Estudos de filosofia do direito. 3. a ed., São Paulo: Saraiva, 1999.

Introdução à ciência do Direito. $25^{\mathrm{a}}$ edição. São Paulo: Editora Revista dos Tribunais, 2000.

MORAES, Alexandre de. Curso de direito constitucional. 23 ${ }^{\mathrm{a}}$ ed. São Paulo:Atlas, 2008. p. 194.

NETO, Gercino Gerson Gomes. "A inimputabilidade penal como cláusula pétrea". In: A razão da idade: mitos e verdades. $1^{\mathrm{a}}$ Edição. Coleção Garantias de Direitos. Série Subsídios Tomo VII. Brasília: MJ/SEDH/DCA, 2001.

NEVES, Edeltrudes Rodrigues Pires. Direito, política e cidadania. Direito e Cidadania, ano III, n. 9, mar./jun., 2000.

NUCCI, Guilherme de Souza. Código Penal Comentado. São Paulo: Editora Revista dos Tribunais, 2008. 
NUNES Jr., Vidal Serrano (Coord.). Manual de Direitos Humanos. São Paulo: Editora Verbatim. 2009.

NUNES, Rizzatto. Manual da Monografia Jurídica. Ed. 5, São Paulo: Saraiva, 2007.

OLIVEIRA, Eva Aparecida de; HERMANN, Dirceu Luiz. Algumas considerações teóricas sobre o estado e a educação: a importância da teoria gramsciana. Revista Jurídica, Jataí, v. 3, n. 3, p.77-94, 2002.

OLIVEIRA, Frederico Abrahão de. Vítimas e Criminosos, Porto Alegre: Livraria do Advogado, 1993.

Panorama Nacional. A Execução das Medidas Socioeducativas de Internação Programa Justiça ao Jovem. CNJ, 2012.

PATTO, Maria Helena Souza. Escolas cheias, cadeias vazias: nota sobre as raízes ideológicas. In: DOSSIÊ Crime organizado. São Paulo: USP, 2007. 328 p. (Estudos avançados). ISBN (ISSN 0103-4014).

PAULA, Paulo Afonso Garrido de. "Educação, Direito e cidadania", Revista Igualdade. Livro 0. Curitiba, s/Ed., outubro-dezembro/1995.

PEDROSO, Regina Célia. Os signos da Opressão. História e Violência nas prisões brasileiras. Coleção Teses e Monografias vol. 05. Arquivo do Estado Imprensa Oficial do Estado - São Paulo, 2003.

PIOVESAN, Flávia. "A inconstitucionalidade da redução da maioridade penal”. In: $A$ razão da idade: mitos e verdades. $1^{\mathrm{a}}$ Edição. Coleção Garantias de Direitos. Série Subsídios Tomo VII. Brasília: MJ/SEDH/DCA, 2001.

. "A inconstitucionalidade da redução da maioridade penal". In: A razão da idade: mitos e verdades. $1^{a}$ Edição. Coleção Garantias de Direitos. Série Subsídios Tomo VII. Brasília: MJ/SEDH/DCA, 2001. p. 73-74.

. Direitos Humanos e Justiça Internacional. 1 ${ }^{a}$. Edição. São Paulo: Editora Saraiva, 2007.

Direitos Humanos e o Direito Constitucional Internacional. 8a. edição, revista, ampliada e atualizada. Editora Saraiva. São Paulo, 2007.

RAMOS, André de Carvalho. Responsabilidade Internacional por Violação de Direitos Humanos. Rio de Janeiro: Renovar, 2004.

Teoria Geral dos Direitos Humanos na Ordem Internacional. São Paulo: Renovar, 2005.

RAMOS, Elival da Silva. Controle de constitucionalidade no Brasil: perspectivas de evolução. São Paulo:Saraiva, 2010. 
RANIERI, Nina Beatriz Stocco (coord.) e RIGHETTI, Sabine (Org.). Direito à Educação. Aspectos Constitucionais. São Paulo: Editora da Universidade de São Paulo, 2009.

. Direito ao Desenvolvimento e Direito à Educação - Relações de Realização e Tutela. In. Revista dos Tribunais. a. 2, n.6, 1994.

Educação Superior, Direito e Estado na Lei de Diretrizes e Bases (Lei n. 9.394/96). São Paulo: EDUSP, 2000.

Educação superior, direito e Estado na lei de diretrizes e bases (Lei n. 9.394/96), São Paulo, EDUSP/FAPESP, 2000.

. O Estado Democrático de Direito e o Sentido da exigência de Preparo da Pessoa para o Exercício da Cidadania, pela via da Educação, Tese (Livre-Docência). Faculdade de Direito da Universidade de São Paulo, São Paulo, 2009.

RAVENTÓS SANTAMARIA, Francesc. Hacia un espacio educativo europeo: la concertación de las políticas de educación y control en la Europa Comunitaria. Poder y control: revista hispano-latinoamericana de disciplinas sobre el control social, Barcelona, n. 1, p.201-205, 1988.

REALE, Miguel. Lições Preliminares de Direito, 16, Ed. São Paulo: Saraiva, 1988. . Teoria Tridimensional do Direito, $5^{\mathrm{a}}$ ed., Editora Saraiva, São Paulo, 2003.

REYNOLDS. Willian L. Judicial Process in a Nutshell. $2^{\text {nd }}$ edition. Maryland: West Group, 1991, pp.143-154.

ROMANO, Roberto. Educação e direitos humanos. In: DIREITOS humanos: visões contemporâneas. São Paulo: Associação Juízes para a Democracia, 2001.

ROUSSEAU. Jean-Jacques, O Contrato Social, Livro III, Capítulos III e IV.

RUTKOSKI, Joslai Silva. A pedagogia de Paulo Freire: uma proposta da educação para os direitos humanos. In: PIOVESAN, Flavia. Direitos humanos: volume I. Curitiba: Juruá, 2006. 735 p. ISBN 85-362-1152-0.

SÁ, Geraldo Ribeiro de. A prisão dos Excluídos. Origens e Reflexões sobre a Pena Privativa de Liberdade. Rio de Janeiro: Diadorim Editora Ltda.,1996.

SABINO. Marco Antonio da Costa. Quando o Judiciário Ultrapassa seus Limites Constitucionais e Institucionais.

SALLA, F. A. Educação como Processo de Reabilitação. In. MAIDA, J. D. (org.). Presídios e educação. São Paulo: FUNAP, 1993. 
SANTOS, Boaventura de Sousa. Globalização: fatalidade ou utopia. Porto: Afrontamento, 2001. 555 p. (A sociedade portuguesa perante os desafios da globalização; v. 1).

- Por uma concepção multicultural de direitos humanos, in Santos, Boaventura de Souza (org.), Reconhecer para libertar os caminhos do cosmopolitismo multicultural, Rio de Janeiro, Civilização Brasileira, 2003.

SANTOS, Marcelo Fausto Figueiredo. Teoria Geral do Estado. 2a edição. São Paulo: Atlas, 2001.

SARLET, Ingo Wolfgang. Dimensões da dignidade: ensaios de filosofia do direito e direito constitucional. Porto Alegre, Livraria do Advogado, 2005.

SEDH/DCA, 2001.

SILVA, José Afonso da Silva. Comentário Textual à Constituição. São Paulo: Malheiros Editores, 2009.

Curso de Direito Constitucional Positivo. $30^{\mathrm{a}}$. edição revista e atualizada. São Paulo: Malheiros Editores, 2008.

SILVA, Roberto da. Os filhos do governo. A formação da identidade criminosa em crianças órfãs e abandonadas. São Paulo: Ática, 1997, p.173.

SILVA, Virgílio Afonso da. O Judiciário e as políticas públicas: entre transformação social e obstáculo à realização dos direitos sociais. In: Cláudio Pereira de Souza Neto \& Daniel Sarmento, Direitos sociais: fundamentação, judicialização e direitos sociais em espécies, Rio de Janeiro: Lumen Juris, 2008: 587-599.

SILVA. Enid Rocha Andrade da. "O perfil da criança e do adolescente nos abrigos pesquisados". In. SILVA. Enid Rocha Andrade da (Coord.). O Direito à Convivência Familiar e Comunitária: os abrigos para crianças e adolescentes no Brasil. Brasília : IPEA/CONANDA, 2004.

SINASE/Sistema Nacional De Atendimento Socioeducativo - Secretaria Especial dos Direitos Humanos - Brasília-DF: CONANDA, 2006.p. 59.

SOUSA Jr., José Geraldo de. “A construção social e teórica da criança no imaginário jurídico". In: A razão da idade: mitos e verdades. 1ª Edição. Coleção Garantias de Direitos. Série Subsídios Tomo VII. Brasília: MJ/SEDH/DCA, 2001.

SOUSA, Eliane Ferreira de. Direito à Educação requisito para o desenvolvimento do país. 1 ${ }^{\mathrm{a}}$. Edição. São Paulo: Editora Saraiva, 2010.

SUNDFELD, Carlos Ari. Fundamentos de direito público. São Paulo: Malheiros, 2002. 
TAVARES, André Ramos. Curso de Direito Constitucional. 5a edição revista e atualizada. Editora Saraiva. São Paulo, 2007.

TELLES Jr., Goffredo da Silva; GRAU, Eros Roberto. "A desnecessária e inconstitucional redução da maioridade penal". In: A razão da idade: mitos e verdades.

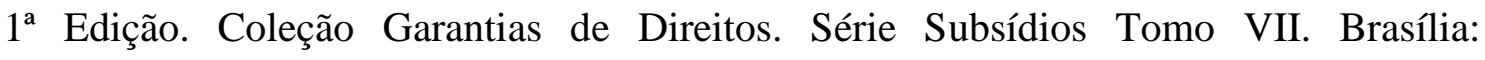
MJ/SEDH/DCA, 2001.

Terceiro Relatório Nacional de Direitos Humanos, 2006 - Núcleo de Estudos da Violência da USP (NEV/USP) e Comissão Teotônio Vilela.

TERRA, Eugênio Couto. “A idade penal mínima como cláusula pétrea”. In: A razão da idade: mitos e verdades. $1^{a}$ Edição. Coleção Garantias de Direitos. Série Subsídios Tomo VII. Brasília: MJ/SEDH/DCA, 2001.

VIALI FILHO, Fernando Alves. A eficácia dos direitos fundamentais à educação como prevenção dos conflitos sociais. Cidadania e Justiça, Rio de Janeiro, v. 7, n. 14, p.99106, jul./dez. 2004.

VICENTIN, Maria Cristina G.onçalves. A vida em Rebelião. Jovens em conflito com a Lei. São Paulo: Hucitec: Fapesp, 2005. p.210.

VIOLANTE, Maria Lúcia Vieira. O dilema do decente malandro. São Paulo, CortezAutores Associados, 1982.

WEFFORT, Francisco C. Os Clássicos da Política. 14 ed. São Paulo: Ática, 2006.

WEIL, Eric. A educação enquanto problema do nosso tempo._In: POMBO, Olga. Quatro textos excêntricos. Lisboa: Relógio D'água, 2000.

YAMAMOTO, Aline (Org.) et al. Educação em prisões. São Paulo: AlfaSol, 2010. 128 p. (Cereja discute; v. 1).

ZAFFARONI, Raul, in CURY, Munir (Org). Estatuto da Criança e do Adolescente comentado. Malheiros Editores, 2008.

ZAYAT, Demián. La igualdad en el acceso a la educación: comentario al fallo González de Delgado, Cristina y otros c. Universidad Nacional de Córdoba s. Amparo. Más Derecho?: Revista de ciencias jurídicas, Buenos Aires, n. 4, p.527-553, set. 2004. 
ANEXOS 


\section{TABELAS SOBRE A INFÂNCIA E ADOLESCÊNCIA NO BRASIL}

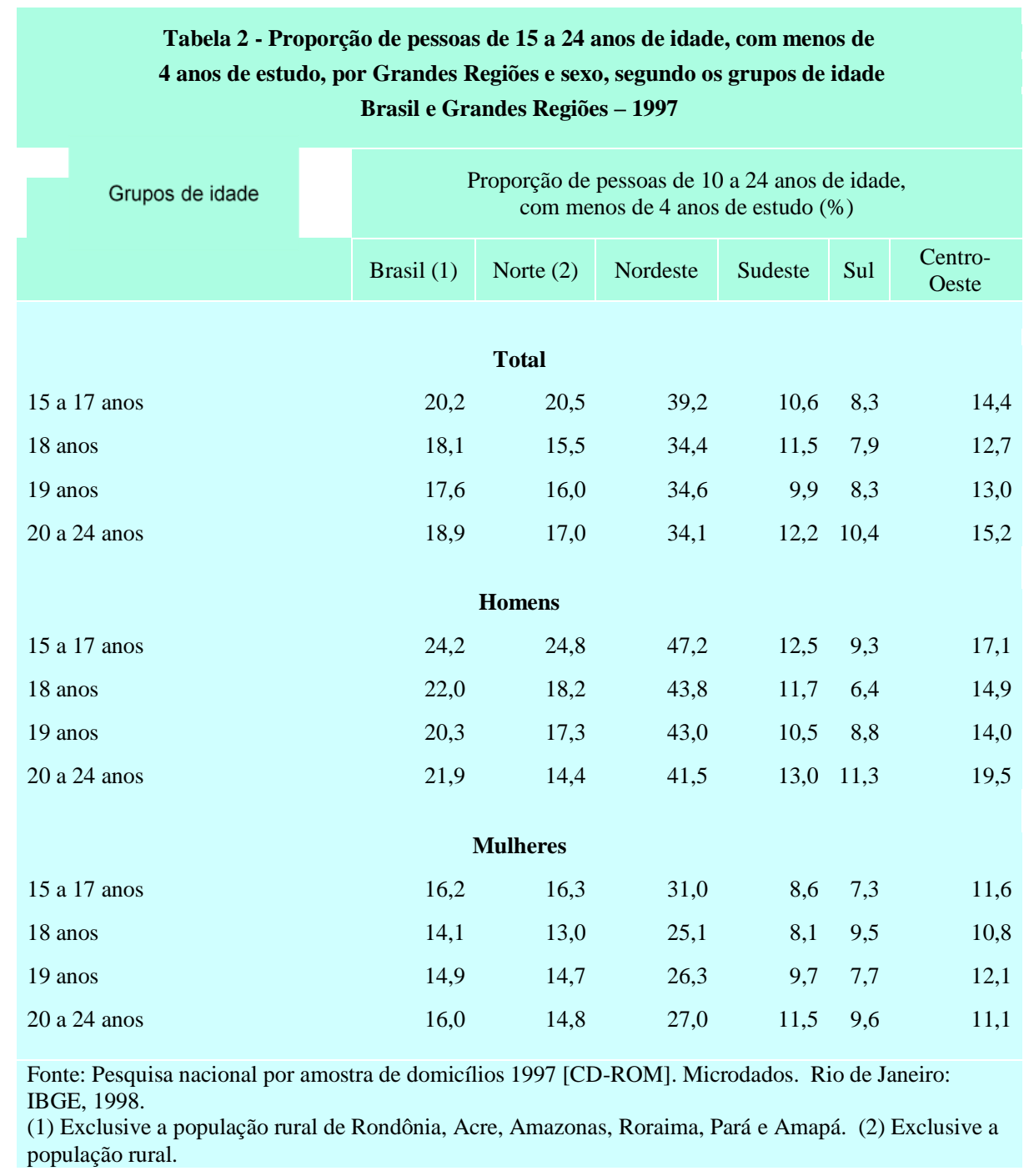




\begin{tabular}{|c|c|c|c|c|c|c|}
\hline \multicolumn{7}{|c|}{$\begin{array}{l}\text { Tabela } 3 \text { - Média de anos de estudo das pessoas de } 10 \text { a } 24 \text { anos de idade, } \\
\text { por Grandes Regiões e situação do domicílio, segundo os grupos de idade } \\
\text { Brasil e Grandes Regiões - } 1997\end{array}$} \\
\hline \multirow{2}{*}{ Grupos de idade } & \multicolumn{6}{|c|}{ Média de anos de estudo das pessoas de 10 a 24 anos de idade } \\
\hline & Brasil (1) & Norte (2) & Nordeste & Sudeste & Sul & $\begin{array}{l}\text { Centro- } \\
\text { Oeste }\end{array}$ \\
\hline \multicolumn{7}{|c|}{ Total } \\
\hline 10 anos & 3,0 & 2,7 & 2,3 & 3,4 & 3,5 & 3,3 \\
\hline 11 anos & 3,6 & 3,3 & 2,8 & 4,2 & 4,3 & 3,9 \\
\hline 12 anos & 4,4 & 4,0 & 3,4 & 4,9 & 5,1 & 4,6 \\
\hline 13 anos & 5,0 & 4,6 & 3,9 & 5,7 & 5,7 & 5,2 \\
\hline 14 anos & 5,6 & 5,0 & 4,4 & 6,4 & 6,6 & 5,9 \\
\hline 15 anos & 6,2 & 5,7 & 4,9 & 7,0 & 7,1 & 6,5 \\
\hline 16 anos & 6,7 & 6,3 & 5,3 & 7,5 & 7,7 & 7,0 \\
\hline 17 anos & 7,1 & 7,0 & 5,7 & 8,0 & 8,0 & 7,2 \\
\hline 18 anos & 7,4 & 7,3 & 5,9 & 8,3 & 8,2 & 7,9 \\
\hline 19 anos & 7,8 & 7,5 & 6,2 & 8,7 & 8,5 & 8,0 \\
\hline 20 a 24 anos & 7,9 & 8,0 & 6,5 & 8,7 & 8,4 & 8,0 \\
\hline \multicolumn{7}{|c|}{ Urbana } \\
\hline 10 anos & 3,2 & 2,7 & 2,6 & 3,4 & 3,6 & 3,4 \\
\hline 11 anos & 3,9 & 3,3 & 3,2 & 4,2 & 4,3 & 4,1 \\
\hline 12 anos & 4,7 & 4,0 & 3,8 & 5,0 & 5,2 & 4,8 \\
\hline 13 anos & 5,3 & 4,6 & 4,4 & 5,8 & 5,8 & 5,4 \\
\hline 14 anos & 6,0 & 5,0 & 5,0 & 6,5 & 6,7 & 6,1 \\
\hline 15 anos & 6,6 & 5,7 & 5,5 & 7,1 & 7,2 & 6,7 \\
\hline 16 anos & 7,1 & 6,3 & 6,0 & 7,7 & 7,9 & 7,2 \\
\hline 17 anos & 7,6 & 7,0 & 6,5 & 8,2 & 8,2 & 7,5 \\
\hline 18 anos & 8,0 & 7,3 & 6,8 & 8,6 & 8,4 & 8,2 \\
\hline 19 anos & 8,3 & 7,5 & 7,0 & 8,9 & 8,9 & 8,2 \\
\hline 20 a 24 anos & 8,5 & 8,0 & 7,4 & 9,0 & 8,8 & 8,4 \\
\hline \multicolumn{7}{|c|}{ Rural } \\
\hline 10 anos & 2,3 & - & 1,8 & 3,0 & 3,5 & 2,7 \\
\hline 11 anos & 2,9 & - & 2,2 & 3,7 & 4,2 & 3,2 \\
\hline 12 anos & 3,4 & - & 2,7 & 4,4 & 4,9 & 3,7 \\
\hline 13 anos & 3,9 & - & 3,0 & 4,9 & 5,5 & 4,4 \\
\hline 14 anos & 4,4 & - & 3,6 & 5,4 & 6,2 & 5,0 \\
\hline 15 anos & 4,9 & - & 3,9 & 5,9 & 6,7 & 5,3 \\
\hline 16 anos & 5,2 & - & 4,2 & 6,3 & 6,9 & 5,8 \\
\hline 17 anos & 5,2 & - & 4,2 & 6,1 & 7,0 & 5,9 \\
\hline 18 anos & 5,4 & - & 4,4 & 6,3 & 7,5 & 6,1 \\
\hline 19 anos & 5,5 & - & 4,5 & 6,7 & 7,1 & 6,3 \\
\hline 20 a 24 anos & 5,3 & - & 4,5 & 6,0 & 6,8 & 5,8 \\
\hline
\end{tabular}

Fonte: Pesquisa nacional por amostra de domicílios 1997 [CD-ROM]. Microdados. Rio de Janeiro: IBGE, 1998.

(1) Exclusive a população rural de Rondônia, Acre, Amazonas, Roraima, Pará e Amapá. (2) Exclusive a população rural 
Tabela 4 - Média de anos de estudo das pessoas de 10 a 24 anos de idade, por grupos de idade e renda mensal familiar per capita, segundo as Grande Regiões Brasil e Grandes Regiões - 1997

\begin{tabular}{|c|c|c|c|c|c|c|c|c|}
\hline \multirow{3}{*}{ Grandes Regiōes } & \multicolumn{8}{|c|}{$\begin{array}{l}\text { Média de anos de estudo das pessoas de } 10 \text { a } 24 \text { anos de idade, } \\
\text { por grupos de idade e renda mensal familiar per capita }\end{array}$} \\
\hline & \multicolumn{2}{|c|}{10 a 11 anos } & \multicolumn{2}{|c|}{12 a 14 anos } & \multicolumn{2}{|c|}{15 a 17 anos } & \multicolumn{2}{|c|}{18 a 24 anos } \\
\hline & $\begin{array}{c}\text { Até } 1 / 4 \\
\text { do } \\
\text { salário } \\
\text { mínimo }\end{array}$ & $\begin{array}{c}\text { Mais } \\
\text { de } 2 \\
\text { salários } \\
\text { mínimos }\end{array}$ & $\begin{array}{l}\text { Até } 1 / 4 \\
\text { do } \\
\text { salário } \\
\text { mínimo }\end{array}$ & $\begin{array}{c}\text { Mais } \\
\text { de } 2 \\
\text { salários } \\
\text { mínimos }\end{array}$ & $\begin{array}{l}\text { Até } 1 / 4 \\
\text { do } \\
\text { salário } \\
\text { mínimo }\end{array}$ & $\begin{array}{c}\text { Mais } \\
\text { de } 2 \\
\text { salários } \\
\text { mínimos }\end{array}$ & $\begin{array}{l}\text { Até } 1 / 4 \\
\text { do } \\
\text { salário } \\
\text { mínimo }\end{array}$ & $\begin{array}{c}\text { Mais } \\
\text { de } 2 \\
\text { salários } \\
\text { mínimos }\end{array}$ \\
\hline Brasil (1) & 2,3 & 4,2 & 3,4 & 6,4 & 4,5 & 8,6 & 4,6 & 10,6 \\
\hline Norte (2) & 2,3 & 4,0 & 3,5 & 5,9 & 5,1 & 8,1 & 5,7 & 10,3 \\
\hline Nordeste & 2,0 & 4,0 & 3,0 & 6,1 & 4,0 & 8,3 & 4,2 & 10,6 \\
\hline Sudeste & 3,0 & 4,2 & 4,5 & 6,5 & 5,5 & 8,6 & 5,6 & 10,6 \\
\hline Sul & 3,1 & 4,5 & 4,7 & 6,7 & 5,5 & 9,0 & 5,5 & 10,7 \\
\hline Centro-Oeste & 2,7 & 4,3 & 4,1 & 6,5 & 5,1 & 8,4 & 5,6 & 10,4 \\
\hline
\end{tabular}

Fonte: Pesquisa nacional por amostra de domicílios 1997 [CD-ROM]. Microdados. Rio de Janeiro: IBGE, 1998.

(1) Exclusive a população rural de Rondônia, Acre, Amazonas, Roraima, Pará e Amapá. (2) Exclusive a popu -lação rural. 


\begin{tabular}{|c|c|c|c|c|c|c|}
\hline \multicolumn{7}{|c|}{$\begin{array}{c}\text { Tabela } 5 \text {-Taxas de escolarização das pessoas de } 4 \text { a } 24 \text { anos de idade, } \\
\text { por grupos de idade e situação do domicílio, segundo as Grandes Regiões } \\
\text { Brasil e Grandes Regiões - } 1997\end{array}$} \\
\hline \multirow[t]{2}{*}{ Grandes Regiões } & \multicolumn{6}{|c|}{$\begin{array}{c}\text { Taxas de escolarização das pessoas de } 4 \text { a } 24 \text { anos de idade, } \\
\text { por grupos de idade e situação do domicílio }\end{array}$} \\
\hline & 4 anos & $\begin{array}{l}5 \text { e } 6 \\
\text { anos }\end{array}$ & $\begin{array}{c}7 \text { a } \\
14 \text { anos }\end{array}$ & $\begin{array}{c}15 \text { a } 17 \\
\text { anos }\end{array}$ & $\begin{array}{l}18 \text { e } 19 \\
\text { anos }\end{array}$ & $\begin{array}{l}20 \text { a } 24 \\
\text { anos }\end{array}$ \\
\hline \multicolumn{7}{|c|}{ Total } \\
\hline Brasil (1) & 36,4 & 66,6 & 93,0 & 73,3 & 45,8 & 21,9 \\
\hline Norte (2) & 36,1 & 71,6 & 91,9 & 75,9 & 51,7 & 27,3 \\
\hline Nordeste & 44,5 & 69,8 & 89,4 & 69,3 & 45,4 & 21,1 \\
\hline Sudeste & 35,5 & 67,3 & 95,5 & 77,4 & 47,1 & 22,5 \\
\hline Sul & 26,9 & 60,2 & 94,9 & 70,4 & 40,0 & 19,6 \\
\hline Centro-Oeste & 25,1 & 59,2 & 93,2 & 71,1 & 46,4 & 22,1 \\
\hline \multicolumn{7}{|c|}{ Urbana } \\
\hline Brasil (1) & 41,0 & 71,6 & 94,5 & 77,1 & 49,5 & 24,2 \\
\hline Norte (2) & 36,1 & 71,6 & 91,9 & 75,9 & 51,7 & 27,3 \\
\hline Nordeste & 55,7 & 77,3 & 91,7 & 75,1 & 52,7 & 25,2 \\
\hline Sudeste & 38,9 & 71,8 & 96,2 & 79,8 & 49,3 & 23,7 \\
\hline Sul & 30,9 & 65,0 & 95,5 & 73,9 & 43,2 & 22,4 \\
\hline Centro-Oeste & 28,9 & 64,1 & 95,2 & 74,4 & 49,5 & 24,7 \\
\hline \multicolumn{7}{|c|}{ Rural } \\
\hline Brasil (1) & 22,2 & 51,6 & $\mathbf{8 8 , 0}$ & 59,1 & 30,6 & 11,6 \\
\hline Norte (2) & 0,0 & 0,0 & 0,0 & 0,0 & 0,0 & 0,0 \\
\hline Nordeste & 28,9 & 59,1 & 85,8 & 59,3 & 32,5 & 12,9 \\
\hline Sudeste & 15,1 & 41,1 & 91,2 & 60,0 & 28,2 & 11,6 \\
\hline Sul & 13,3 & 44,7 & 92,7 & 58,1 & 28,6 & 8,4 \\
\hline Centro-Oeste & 8,0 & 39,9 & 84,5 & 53,4 & 25,8 & 8,3 \\
\hline $\begin{array}{l}\text { Fonte: Pesquisa nacion } \\
\text { IBGE, } 1998 \text {. } \\
\text { (1) Exclusive a popula } \\
\text { população rural. }\end{array}$ & Rondônia & cre, Ama & CD-ROM] & Microdados & $\begin{array}{l}\text { Rio de Jan } \\
\text { apá. (2) E }\end{array}$ & ro: \\
\hline
\end{tabular}




\begin{tabular}{|c|c|c|c|c|c|c|}
\hline \multirow{3}{*}{ Grupos de idade } & $\begin{array}{l}\text { População re } \\
\text { tiva, por Gra }\end{array}$ & $\begin{array}{l}\text { sidente tot: } \\
\text { ndes Regiõ } \\
\text { Brasil - 19 }\end{array}$ & $\begin{array}{l}\text { e de } 0 \text { a } 2 \\
\text { es, segund } \\
97\end{array}$ & $\begin{array}{l}4 \text { anos de ic } \\
\text { os grupos }\end{array}$ & $\begin{array}{l}\text { ade, } \\
\text { le idade }\end{array}$ & \multirow[t]{2}{*}{ (continua) } \\
\hline & \multicolumn{5}{|c|}{ População residente total e de 0 a 24 anos de idade } & \\
\hline & Brasil (1) & Norte (2) & Nordeste & Sudeste & Sul & $\begin{array}{l}\text { Centro- } \\
\text { Oeste }\end{array}$ \\
\hline \multicolumn{7}{|c|}{ Números absolutos } \\
\hline População total & $\begin{array}{r}156128 \\
003\end{array}$ & \#\#\#\#\#\# & \#\#\#\#\#\# & \#\#\#\#\#\# & \#\#\#\#\#\# & \#\#\#\#\#\# \\
\hline 0 a 6 anos & 21231045 & \#\#\#\#\#\# & $\begin{array}{r}6916 \\
618\end{array}$ & \#\#\#\#\#\# & \#\#\#\#\#\# & \#\#\#\#\#\# \\
\hline Menos de 1 ano & 2931013 & 188407 & 929311 & $\begin{array}{r}1123 \\
247\end{array}$ & 466983 & 213206 \\
\hline 1 ano & 2931514 & 169480 & $\begin{array}{r}941453 \\
1007\end{array}$ & $\begin{array}{r}1169 \\
735 \\
1223\end{array}$ & 425941 & 217148 \\
\hline 2 anos & 3092860 & 165833 & 981 & $\begin{array}{r}639 \\
1167\end{array}$ & 466560 & 219860 \\
\hline 3 anos & 2990574 & 179965 & $\begin{array}{r}961863 \\
1039\end{array}$ & $\begin{array}{r}410 \\
1249\end{array}$ & 473130 & 202338 \\
\hline 4 anos & 3172197 & 178686 & $\begin{array}{r}222 \\
1037\end{array}$ & $\begin{array}{r}791 \\
1167\end{array}$ & 478332 & 214867 \\
\hline 5 anos & 3083345 & 173816 & 413 & $\begin{array}{r}372 \\
1173\end{array}$ & 481242 & 217341 \\
\hline 6 anos & 3029542 & 169266 & 999375 & 841 & 468846 & 209790 \\
\hline 7 a 14 anos & 26863331 & $\begin{array}{r}1460 \\
186\end{array}$ & \#\#\#\#\#\# & \#\#\#\#\#\# & \#\#\#\#\#\# & \#\#\#\#\#\# \\
\hline 7 anos & 3190255 & 166217 & $\begin{array}{r}1009 \\
152 \\
1081\end{array}$ & $\begin{array}{r}1284 \\
083 \\
1275\end{array}$ & 485858 & 237281 \\
\hline 8 anos & 3242917 & 177455 & $\begin{array}{r}598 \\
1144\end{array}$ & $\begin{array}{r}013 \\
1325\end{array}$ & 454065 & 244422 \\
\hline 9 anos & 3381862 & 173320 & $\begin{array}{r}756 \\
1148\end{array}$ & $\begin{array}{r}560 \\
1337\end{array}$ & 486304 & 243556 \\
\hline 10 anos & 3380308 & 184950 & $\begin{array}{r}044 \\
1136\end{array}$ & $\begin{array}{r}778 \\
1256\end{array}$ & 463266 & 237894 \\
\hline 11 anos & 3332069 & 190689 & $\begin{array}{r}266 \\
1141\end{array}$ & $\begin{array}{r}545 \\
1380\end{array}$ & 498464 & 244798 \\
\hline 12 anos & 3430693 & 178667 & $\begin{array}{r}363 \\
1111\end{array}$ & $\begin{array}{r}944 \\
1346\end{array}$ & 493026 & 227388 \\
\hline 13 anos & 3352675 & 190993 & $\begin{array}{r}622 \\
1177\end{array}$ & $\begin{array}{r}938 \\
1424\end{array}$ & 462527 & 234254 \\
\hline 14 anos & 3552552 & 197895 & 452 & 303 & 508563 & 237502 \\
\hline 15 a 17 anos & 10399484 & 566329 & \#\#\#\#\#\# & \#\#\#\#\# & $\begin{array}{r}1483 \\
371\end{array}$ & 732209 \\
\hline 15 anos & 3617469 & 203219 & $\begin{array}{r}1151 \\
237 \\
1122\end{array}$ & $\begin{array}{r}1486 \\
564 \\
1412\end{array}$ & 510759 & 259783 \\
\hline 16 anos & 3443485 & 179685 & $\begin{array}{r}358 \\
1044\end{array}$ & $\begin{array}{r}975 \\
1384\end{array}$ & 487117 & 236408 \\
\hline 17 anos & 3338530 & 183425 & $\begin{array}{r}150 \\
1022\end{array}$ & $\begin{array}{r}181 \\
1333\end{array}$ & 485495 & 236018 \\
\hline 18 anos & 3205499 & 181931 & 578 & $\begin{array}{r}719 \\
1303\end{array}$ & 427116 & 235458 \\
\hline 19 anos & 2975400 & 165102 & $\begin{array}{r}878516 \\
3924\end{array}$ & $\begin{array}{r}702 \\
5800\end{array}$ & $\begin{array}{r}407893 \\
1960\end{array}$ & 216353 \\
\hline 20 a 24 anos & 13454058 & 714267 & 961 & 848 & 999 & 1029430 \\
\hline
\end{tabular}




\begin{tabular}{|c|c|c|c|c|c|c|}
\hline \multicolumn{7}{|c|}{$\begin{array}{c}\text { Tabela } 7 \text { - População residente total e de } 0 \text { a } 24 \text { anos de idade, } \\
\text { absoluta e relativa, por Grandes Regiões, segundo os grupos de idade } \\
\text { Brasil e Grandes Regiões - } 1997\end{array}$} \\
\hline \multirow{2}{*}{ Grupos de idade } & \multicolumn{6}{|c|}{ População residente total e de 0 a 24 anos de idade (\%) } \\
\hline & Brasil (1) & Norte (2) & Nordeste & Sudeste & Sul & $\begin{array}{l}\text { Centro- } \\
\text { Oeste }\end{array}$ \\
\hline \multicolumn{7}{|c|}{ Números relativos (\%) } \\
\hline População total & 100,0 & 100,0 & 100,0 & 100,0 & 100,0 & 100,0 \\
\hline 0 a 6 anos & 13,6 & 16,7 & 15,2 & 12,1 & 13,6 & 13,8 \\
\hline Menos de 1 ano & 1,9 & 2,6 & 2,0 & 1,6 & 2,0 & 2,0 \\
\hline 1 ano & 1,9 & 2,3 & 2,1 & 1,7 & 1,8 & 2,0 \\
\hline 2 anos & 2,0 & 2,3 & 2,2 & 1,8 & 1,9 & 2,0 \\
\hline 3 anos & 1,9 & 2,4 & 2,1 & 1,7 & 2,0 & 1,9 \\
\hline 4 anos & 2,0 & 2,4 & 2,3 & 1,8 & 2,0 & 2,0 \\
\hline 5 anos & 2,0 & 2,4 & 2,3 & 1,7 & 2,0 & 2,0 \\
\hline 6 anos & 1,9 & 2,3 & 2,2 & 1,7 & 2,0 & 1,9 \\
\hline 7 a 14 anos & 17,2 & 19,8 & 19,7 & 15,6 & 16,1 & 17,6 \\
\hline 7 anos & 2,0 & 2,3 & 2,2 & 1,9 & 2,0 & 2,2 \\
\hline 8 anos & 2,1 & 2,4 & 2,4 & 1,9 & 1,9 & 2,3 \\
\hline 9 anos & 2,2 & 2,4 & 2,5 & 1,9 & 2,0 & 2,3 \\
\hline 10 anos & 2,2 & 2,5 & 2,5 & 2,0 & 1,9 & 2,2 \\
\hline 11 anos & 2,1 & 2,6 & 2,5 & 1,8 & 2,1 & 2,3 \\
\hline 12 anos & 2,2 & 2,4 & 2,5 & 2,0 & 2,1 & 2,1 \\
\hline 13 anos & 2,1 & 2,6 & 2,4 & 2,0 & 1,9 & 2,2 \\
\hline 14 anos & 2,3 & 2,7 & 2,6 & 2,1 & 2,1 & 2,2 \\
\hline 15 a 17 anos & 6,7 & $\mathbf{7 , 7}$ & 7,3 & 6,3 & 6,2 & 6,8 \\
\hline 15 anos & 2,3 & 2,8 & 2,5 & 2,2 & 2,1 & 2,4 \\
\hline 16 anos & 2,2 & 2,4 & 2,5 & 2,1 & 2,0 & 2,2 \\
\hline 17 anos & 2,1 & 2,5 & 2,3 & 2,0 & 2,0 & 2,2 \\
\hline 18 anos & 2,1 & 2,5 & 2,2 & 2,0 & 1,8 & 2,2 \\
\hline 19 anos & 1,9 & 2,2 & 1,9 & 1,9 & 1,7 & 2,0 \\
\hline 20 a 24 anos & 8,6 & 9,7 & 8,6 & 8,5 & 8,2 & 9,5 \\
\hline
\end{tabular}

Fonte: Pesquisa nacional por amostra de domicílios 1997 [CD-ROM]. Microdados. Rio de Janeiro: IBGE, 1998.

(1) Exclusive a população rural de Rondônia, Acre, Amazonas, Roraima, Pará e Amapá. (2) Exclusive a população rural. 
Tabela 8 - Proporção de pessoas com rendimento de até 1/2 salário mínimo, per capita, por Grandes Regiões, segundo os grupos de idade Brasil e Grandes Regiões - 1997

\section{Grupos de idade}

0 a 6 anos

7 a 14 anos

15 a 17 anos

18 a 24 anos
Proporção de pessoas com rendimento de até $1 / 2$ salário mínimo, per capita (\%)

Brasil Norte Nordeste Sudeste Sul Centro-

(1) (2) Nordeste Sudeste Sul Oeste

$\begin{array}{llllll}25,0 & 30,1 & 47,5 & 13,1 & 16,2 & 19,\end{array}$

$\begin{array}{llllll}37,7 & 41,1 & 61,0 & 23,1 & 27,2 & 29,5\end{array}$

$\begin{array}{llllll}35,4 & 39,3 & 60,0 & 19,6 & 23,6 & 27,2\end{array}$

$27,3 \quad 29,8 \quad 51,0 \quad 14,0 \quad 16,2 \quad 18,0$

$\begin{array}{llllll}21,6 & 24,6 & 43,1 & 10,6 & 12,3 & 14,8\end{array}$

Fonte: Pesquisa nacional por amostra de domicílios 1997 [CD-ROM]. Microdados. Rio de Janeiro: IBGE, 1998.

(1) Exclusive a população rural de Rondônia, Acre, Amazonas, Roraima, Pará e Amapá. (2)

Exclusive a população rural. 


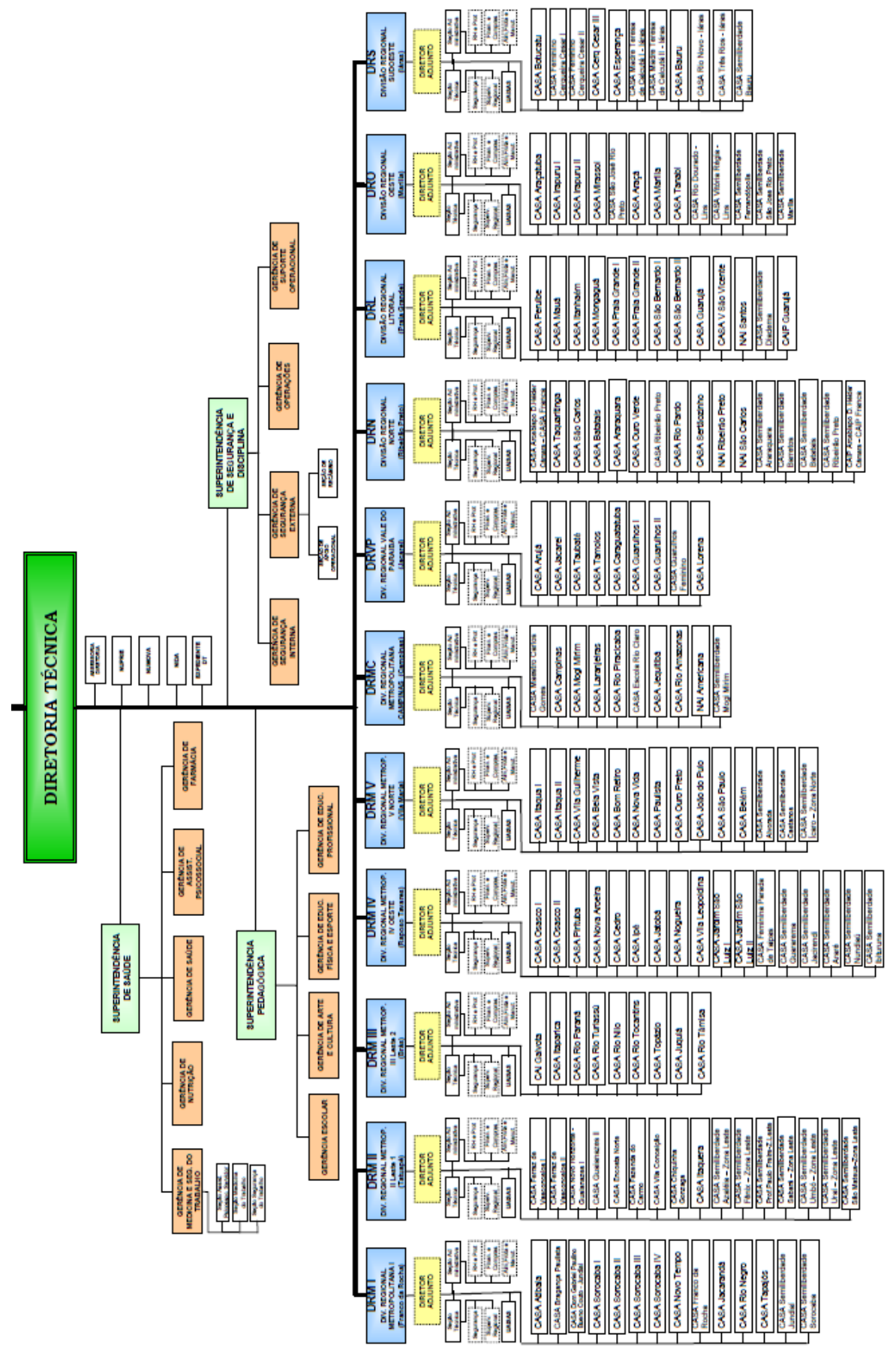


FUNDAÇÃO CASA-SP: NÚMERO DE INTERNOS POR REGIONAL

\begin{tabular}{|c|c|c|c|c|c|c|}
\hline \multicolumn{7}{|c|}{ DRM I - DIV. REGIONAL METROPOLITANA I (Franco da Rocha) } \\
\hline & UNIDADE & Internos & $\begin{array}{c}\text { Atendimento } \\
\text { Inicial }\end{array}$ & $\begin{array}{l}\text { Internação } \\
\text { Provisória }\end{array}$ & Internação & Semiliberdade \\
\hline 1 & CASA Atibaia & $\begin{array}{c}56 \\
\text { adolescentes }\end{array}$ & - & 16 & 40 & - \\
\hline 2 & $\begin{array}{c}\text { CASA Bragança } \\
\text { Paulista }\end{array}$ & $\begin{array}{c}56 \\
\text { adolescentes }\end{array}$ & - & 16 & 40 & - \\
\hline 3 & $\begin{array}{c}\text { CASA Dom } \\
\text { Gabriel Paulino } \\
\text { Bueno Couto - } \\
\text { Jundiaí }\end{array}$ & $\begin{array}{c}56 \\
\text { adolescentes }\end{array}$ & - & 16 & 40 & - \\
\hline 4 & $\begin{array}{c}\text { CASA Sorocaba } \\
\text { I }\end{array}$ & $\begin{array}{c}56 \\
\text { adolescentes }\end{array}$ & - & 16 & 40 & - \\
\hline 5 & $\begin{array}{c}\text { CASA Sorocaba } \\
\text { II }\end{array}$ & $\begin{array}{c}56 \\
\text { adolescentes }\end{array}$ & - & 56 & - & - \\
\hline 6 & $\begin{array}{c}\text { CASA Sorocaba } \\
\text { III }\end{array}$ & $\begin{array}{c}96 \\
\text { adolescentes }\end{array}$ & - & - & 96 & - \\
\hline 7 & $\begin{array}{c}\text { CASA Sorocaba } \\
\text { IV }\end{array}$ & $\begin{array}{c}24 \\
\text { adolescentes }\end{array}$ & 8 & 16 & - & - \\
\hline 8 & $\begin{array}{c}\text { CASA Franco da } \\
\text { Rocha }\end{array}$ & $\begin{array}{c}40 \\
\text { adolescentes }\end{array}$ & - & 40 & - & - \\
\hline 9 & $\begin{array}{c}\text { CASA Novo } \\
\text { Tempo }\end{array}$ & $\begin{array}{c}56 \\
\text { adolescentes }\end{array}$ & - & 56 & - & - \\
\hline 10 & $\begin{array}{c}\text { CASA } \\
\text { Jacarandá, }\end{array}$ & $\begin{array}{c}80 \\
\text { adolescentes }\end{array}$ & - & 80 & - & - \\
\hline 11 & $\begin{array}{c}\text { CASA Rio } \\
\text { Negro }\end{array}$ & $\begin{array}{c}80 \\
\text { adolescentes }\end{array}$ & - & 80 & - & - \\
\hline 12 & CASA Tapajós & $\begin{array}{c}80 \\
\text { adolescentes }\end{array}$ & - & 80 & - & - \\
\hline 13 & $\begin{array}{c}\text { CASA } \\
\text { Semiliberdade }\end{array}$ & $\begin{array}{c}20 \\
\text { adolescentes }\end{array}$ & - & - & - & 20 \\
\hline
\end{tabular}




\begin{tabular}{|c|c|c|c|c|c|c|}
\hline & Jundiaí & & & & & \\
\hline 14 & $\begin{array}{c}\text { CASA } \\
\text { Semiliberdade } \\
\text { Sorocaba. }\end{array}$ & $\begin{array}{c}20 \\
\text { adolescentes }\end{array}$ & - & - & - & 20 \\
\hline
\end{tabular}

\begin{tabular}{|c|c|c|c|c|c|c|}
\hline \multicolumn{7}{|c|}{ DRM II - DIV. REGIONAL METROP. II Leste 1 (Tatuapé) } \\
\hline & UNIDADE & Internos & $\begin{array}{c}\text { Atendimento } \\
\text { Inicial }\end{array}$ & $\begin{array}{l}\text { Internação } \\
\text { Provisória }\end{array}$ & Internação & Semiliberdade \\
\hline 1 & $\begin{array}{l}\text { CASA Ferraz de } \\
\text { Vasconcelos I }\end{array}$ & $\begin{array}{c}56 \\
\text { adolescentes }\end{array}$ & - & 16 & 40 & - \\
\hline 2 & $\begin{array}{l}\text { CASA Ferraz de } \\
\text { Vasconcelos II }\end{array}$ & $\begin{array}{c}56 \\
\text { adolescentes }\end{array}$ & - & 16 & 40 & - \\
\hline 3 & $\begin{array}{c}\text { CASA Novo Horizonte - } \\
\text { Guaianazes I }\end{array}$ & $\begin{array}{c}44 \\
\text { adolescentes }\end{array}$ & - & - & 44 & - \\
\hline 4 & CASA Guaianazes II & $\begin{array}{c}44 \\
\text { adolescentes }\end{array}$ & - & - & 44 & - \\
\hline 5 & CASA Encosta Norte & $\begin{array}{c}40 \\
\text { adolescentes }\end{array}$ & - & - & 40 & - \\
\hline 6 & $\begin{array}{c}\text { CASA Fazenda do } \\
\text { Carmo }\end{array}$ & $\begin{array}{c}60 \\
\text { adolescentes }\end{array}$ & - & - & 60 & - \\
\hline 7 & CASA Vila Conceição & $\begin{array}{c}60 \\
\text { adolescentes }\end{array}$ & - & - & 60 & - \\
\hline 8 & $\begin{array}{l}\text { CASA Chiquinha } \\
\text { Gonzaga }\end{array}$ & $\begin{array}{c}122 \\
\text { adolescentes }\end{array}$ & 10 & 40 & 72 & - \\
\hline 9 & CASA Itaquera & $\begin{array}{c}152 \\
\text { adolescentes }\end{array}$ & - & - & 152 & - \\
\hline 10 & $\begin{array}{l}\text { CASA Semiliberdade } \\
\text { Azaléia - Zona Leste }\end{array}$ & $\begin{array}{c}20 \\
\text { adolescentes }\end{array}$ & - & - & - & 20 \\
\hline 11 & $\begin{array}{l}\text { CASA Semiliberdade } \\
\text { Fênix - Zona Leste }\end{array}$ & $\begin{array}{c}30 \\
\text { adolescentes }\end{array}$ & - & - & - & 30 \\
\hline 12 & $\begin{array}{c}\text { CASA Semiliberdade } \\
\text { Prof.Paulo Freire- }\end{array}$ & $\begin{array}{c}30 \\
\text { adolescentes }\end{array}$ & - & - & - & 30 \\
\hline
\end{tabular}




\begin{tabular}{|c|c|c|c|c|c|c|}
\hline 13 & Z.Leste & & & & \\
\hline & Sabará - Zona Leste & adolescentes & - & - & 20 \\
\hline 14 & CASA Semiliberdade & 20 & - & - & - & 20 \\
\hline 15 & Umbó - Zona Leste & adolescentes & & & - & 20 \\
\hline 16 & CASA Semiliberdade & 20 & & - & - & 20 \\
\hline
\end{tabular}

\begin{tabular}{|c|c|c|c|c|c|c|}
\hline \multicolumn{7}{|c|}{ DRM III - DIV. REGIONAL METROP. III Leste 2} \\
\hline & UNIDADE & Internos & $\begin{array}{l}\text { Atendimento } \\
\text { Inicial }\end{array}$ & $\begin{array}{l}\text { Internação } \\
\text { Provisória }\end{array}$ & Internação & Semiliberdade \\
\hline 1 & CAI Gaivota & $\begin{array}{c}64 \\
\text { adolescentes }\end{array}$ & - & 64 & - & - \\
\hline 2 & CASA Itaparica & $\begin{array}{c}170 \\
\text { adolescentes }\end{array}$ & - & 170 & - & - \\
\hline 3 & $\begin{array}{c}\text { CASA Rio } \\
\text { Paraná }\end{array}$ & $\begin{array}{c}110 \\
\text { adolescentes }\end{array}$ & - & 110 & - & - \\
\hline 4 & $\begin{array}{l}\text { CASA Rio } \\
\text { Turiassú }\end{array}$ & $\begin{array}{c}120 \\
\text { adolescentes }\end{array}$ & - & 120 & - & - \\
\hline 5 & CASA Rio Nilo & $\begin{array}{c}170 \\
\text { adolescentes }\end{array}$ & - & 170 & - & - \\
\hline 6 & $\begin{array}{l}\text { CASA Rio } \\
\text { Tocantins }\end{array}$ & $\begin{array}{c}80 \\
\text { adolescentes }\end{array}$ & - & 80 & - & - \\
\hline 7 & CASA Topázio & $\begin{array}{c}170 \\
\text { adolescentes }\end{array}$ & - & 170 & - & - \\
\hline 8 & CASA Juquiá & $\begin{array}{c}130 \\
\text { adolescentes }\end{array}$ & - & - & 130 & - \\
\hline 9 & $\begin{array}{l}\text { CASA Rio } \\
\text { Tâmisa. }\end{array}$ & $\begin{array}{c}90 \\
\text { adolescentes }\end{array}$ & - & - & 90 & - \\
\hline
\end{tabular}




\begin{tabular}{|c|c|c|c|c|c|c|}
\hline \multicolumn{7}{|c|}{ DRM IV - DIV. REGIONAL METROP. IV OESTE (Raposo Tavares) } \\
\hline & UNIDADE & Internos & $\begin{array}{l}\text { Atendimento } \\
\text { Inicial }\end{array}$ & $\begin{array}{l}\text { Internação } \\
\text { Provisória }\end{array}$ & Internação & Semiliberdade \\
\hline 1 & CASA Osasco I & $\begin{array}{c}56 \\
\text { adolescente }\end{array}$ & - & 16 & 40 & - \\
\hline 2 & CASA Osasco II & $\begin{array}{c}56 \\
\text { adolescentes }\end{array}$ & - & - & 56 & - \\
\hline 3 & CASA Pirituba & $\begin{array}{c}72 \\
\text { adolescentes }\end{array}$ & - & - & 72 & - \\
\hline 4 & CASA Nova Aroeira & $\begin{array}{c}64 \\
\text { adolescentes }\end{array}$ & - & - & 64 & - \\
\hline 5 & CASA Cedro & $\begin{array}{c}72 \\
\text { adolescentes }\end{array}$ & - & - & 72 & - \\
\hline 6 & CASA Ipê & $\begin{array}{c}90 \\
\text { adolescentes }\end{array}$ & - & - & 90 & - \\
\hline 7 & CASA Jatobá & $\begin{array}{c}60 \\
\text { adolescentes }\end{array}$ & - & -- & 60 & - \\
\hline 8 & CASA Nogueira & $\begin{array}{c}66 \\
\text { adolescentes }\end{array}$ & - & - & 66 & - \\
\hline 9 & $\begin{array}{l}\text { CASA Vila } \\
\text { Leopoldina }\end{array}$ & $\begin{array}{c}150 \\
\text { adolescentes }\end{array}$ & - & - & 150 & - \\
\hline 10 & $\begin{array}{c}\text { CASA Jardim São } \\
\text { Luiz I }\end{array}$ & $\begin{array}{c}44 \\
\text { adolescentes }\end{array}$ & - & - & 44 & - \\
\hline 11 & $\begin{array}{l}\text { CASA Jardim São } \\
\text { Luiz II }\end{array}$ & $\begin{array}{c}44 \\
\text { adolescentes }\end{array}$ & - & - & 44 & - \\
\hline 12 & $\begin{array}{l}\text { CASA Feminina } \\
\text { Parada de Taipas }\end{array}$ & $\begin{array}{c}60 \\
\text { adolescentes }\end{array}$ & - & - & 60 & - \\
\hline 13 & $\begin{array}{c}\text { CASA Semiliberdade } \\
\text { Guararema }\end{array}$ & $\begin{array}{c}20 \\
\text { adolescentes }\end{array}$ & - & - & - & 20 \\
\hline 14 & $\begin{array}{c}\text { CASA Semiliberdade } \\
\text { Jacirendi }\end{array}$ & $\begin{array}{c}20 \\
\text { adolescentes }\end{array}$ & - & - & - & 20 \\
\hline 15 & CASA Semiliberdade & 20 & - & - & - & 20 \\
\hline
\end{tabular}




\begin{tabular}{|c|c|c|c|c|c|c|}
\hline & Araré & adolescentes & & & & \\
\hline 16 & CASA Semiliberdade & 20 & - & - & - & 20 \\
& Nundiaú & adolescentes & & - & - & 20 \\
\hline 17 & $\begin{array}{c}\text { CASA Semiliberdade } \\
\text { Ibituruna }\end{array}$ & adolescentes & & - & & \\
\hline
\end{tabular}

\begin{tabular}{|c|c|c|c|c|c|c|}
\hline \multicolumn{7}{|c|}{ DRM V - DIV. REGIONAL METROP. V NORTE (Vila Maria) } \\
\hline & UNIDADE & Internos & $\begin{array}{c}\text { Atendimento } \\
\text { Inicial }\end{array}$ & $\begin{array}{l}\text { Internação } \\
\text { Provisória }\end{array}$ & Internação & Semiliberdade \\
\hline 1 & CASA Itaqua I & $\begin{array}{c}56 \\
\text { adolescentes }\end{array}$ & - & 16 & 40 & - \\
\hline 2 & CASA Itaqua II & $\begin{array}{c}30 \\
\text { adolescentes }\end{array}$ & - & - & 30 & - \\
\hline 3 & CASA Vila Guilherme & $\begin{array}{c}100 \\
\text { adolescentes }\end{array}$ & - & - & 100 & - \\
\hline 4 & CASA Bela Vista & $\begin{array}{c}80 \\
\text { adolescentes }\end{array}$ & - & - & 80 & - \\
\hline 5 & CASA Bom Retiro & $\begin{array}{c}50 \\
\text { adolescentes }\end{array}$ & - & - & 50 & - \\
\hline 6 & CASA Nova Vida & $\begin{array}{c}45 \\
\text { adolescentes }\end{array}$ & - & - & 45 & - \\
\hline 7 & CASA Paulista & $\begin{array}{c}45 \\
\text { adolescentes }\end{array}$ & - & - & 45 & - \\
\hline 8 & CASA Ouro Preto & $\begin{array}{c}45 \\
\text { adolescentes }\end{array}$ & - & - & 45 & - \\
\hline 9 & CASA João do Pulo & $\begin{array}{c}48 \\
\text { adolescentes }\end{array}$ & - & - & 48 & - \\
\hline 10 & CASA São Paulo & $\begin{array}{c}56 \\
\text { adolescentes }\end{array}$ & - & - & 56 & - \\
\hline 11 & CASA Belém & $\begin{array}{c}56 \\
\text { adolescentes }\end{array}$ & - & - & 56 & - \\
\hline
\end{tabular}




\begin{tabular}{|c|c|c|c|c|c|c|}
\hline 12 & $\begin{array}{c}\text { CASA Semiliberdade } \\
\text { Alvorada }\end{array}$ & adolescentes & - & - & - & 20 \\
\hline 13 & $\begin{array}{c}\text { CASA Semiliberdade } \\
\text { Caetanos }\end{array}$ & 20 & - & - & - & 20 \\
\hline 14 & $\begin{array}{c}\text { CASA Semiliberdade } \\
\text { adolescentes }\end{array}$ & 20 & - & - & - & 20 \\
\hline
\end{tabular}

\begin{tabular}{|c|c|c|c|c|c|c|}
\hline \multicolumn{7}{|c|}{ DRMC - DIV. REGIONAL METROPOLITANA CAMPINAS (Campinas) } \\
\hline & UNIDADE & Internos & $\begin{array}{l}\text { Atendimento } \\
\text { Inicial }\end{array}$ & $\begin{array}{l}\text { Internação } \\
\text { Provisória }\end{array}$ & Internação & Semiliberdade \\
\hline 1 & $\begin{array}{l}\text { CASA Maestro } \\
\text { Carlos Gomes }\end{array}$ & $\begin{array}{c}56 \\
\text { adolescentes }\end{array}$ & - & 16 & 40 & - \\
\hline 2 & CASA Campinas & $\begin{array}{c}56 \\
\text { adolescentes }\end{array}$ & - & - & 56 & - \\
\hline 3 & CASA Mogi Mirim & $\begin{array}{c}56 \\
\text { adolescentes }\end{array}$ & - & 16 & 40 & - \\
\hline 4 & CASA Laranjeiras & $\begin{array}{c}56 \\
\text { adolescentes }\end{array}$ & - & - & 56 & - \\
\hline 5 & $\begin{array}{c}\text { CASA Rio } \\
\text { Piracicaba*(erro 4i) }\end{array}$ & $\begin{array}{c}56 \\
\text { adolescentes }\end{array}$ & - & 12 & 40 & - \\
\hline 6 & $\begin{array}{c}\text { CASA Escola Rio } \\
\text { Claro }\end{array}$ & $\begin{array}{c}56 \\
\text { adolescentes }\end{array}$ & - & 16 & 40 & - \\
\hline 7 & CASA Jequitibá & $\begin{array}{c}72 \\
\text { adolescentes }\end{array}$ & - & - & 72 & - \\
\hline 8 & CASA Rio Amazonas & $\begin{array}{c}46 \\
\text { adolescentes }\end{array}$ & 8 & 38 & - & - \\
\hline 9 & NAI Americana & $\begin{array}{c}12 \\
\text { adolescentes }\end{array}$ & 4 & 8 & - & - \\
\hline 10 & $\begin{array}{c}\text { CASA Semiliberdade } \\
\text { Mogi Mirim }\end{array}$ & $\begin{array}{c}20 \\
\text { adolescentes }\end{array}$ & - & - & - & 20 \\
\hline
\end{tabular}




\begin{tabular}{|c|c|c|c|c|c|c|}
\hline \multicolumn{7}{|c|}{ DRVP - DIV. REGIONALV. REGIONAL VALE DO PARAIBA (Jacarei) } \\
\hline & UNIDADE & Internos & $\begin{array}{c}\text { Atendimento } \\
\text { Inicial }\end{array}$ & $\begin{array}{l}\text { Internação } \\
\text { Provisória }\end{array}$ & Internação & Semiliberdade \\
\hline 1 & CASA Arujá & $\begin{array}{c}56 \\
\text { adolescentes }\end{array}$ & - & 16 & 40 & - \\
\hline 2 & CASA Jacare & $\begin{array}{c}56 \\
\text { adolescentes }\end{array}$ & - & 16 & 40 & - \\
\hline 3 & CASA Taubaté & $\begin{array}{c}56 \\
\text { adolescentes }\end{array}$ & - & 16 & 40 & - \\
\hline 4 & CASA Tamoios & $\begin{array}{c}96 \\
\text { adolescentes }\end{array}$ & - & 32 & 64 & - \\
\hline 5 & CASA Caraguatatuba & $\begin{array}{c}56 \\
\text { adolescentes }\end{array}$ & - & 16 & 40 & -- \\
\hline 6 & CASA Guarulhos I & $\begin{array}{c}56 \\
\text { adolescentes }\end{array}$ & - & - & 56 & - \\
\hline 7 & CASA Guarulhos II & $\begin{array}{c}56 \\
\text { adolescentes }\end{array}$ & - & 40 & 16 & - \\
\hline 8 & $\begin{array}{c}\text { CASA Guarulhos } \\
\text { Feminino }\end{array}$ & $\begin{array}{c}56 \\
\text { adolescentes }\end{array}$ & - & 16 & 40 & - \\
\hline 9 & CASA Lorena & $\begin{array}{c}56 \\
\text { adolescentes }\end{array}$ & - & 16 & 40 & - \\
\hline
\end{tabular}

\begin{tabular}{|c|c|c|c|c|c|c|}
\hline \multicolumn{7}{|c|}{ DRN - DIVISÃO REGIONAL NORTE (Ribeirão Preto) } \\
\hline & UNIDADE & Internos & $\begin{array}{c}\text { Atendimento } \\
\text { Inicial }\end{array}$ & $\begin{array}{c}\text { Internação } \\
\text { Provisória }\end{array}$ & Internação & Semiliberdade \\
\hline 1 & $\begin{array}{c}\text { CASA Arcebispo } \\
\text { D.Hélder Câmara } \\
\text { - CASA Franca }\end{array}$ & adolescentes & 10 & 16 & 40 & - \\
\hline 2 & CASA & 56 & - & 16 & 40 & - \\
\hline 3 & Taquaritinga & adolescentes & & & 40 & \\
\hline
\end{tabular}




\begin{tabular}{|c|c|c|c|c|c|c|}
\hline 4 & CASA Batatais & $\begin{array}{c}56 \\
\text { adolescentes }\end{array}$ & - & 16 & 40 & - \\
\hline 5 & CASA Araraquara & $\begin{array}{c}88 \\
\text { adolescentes }\end{array}$ & - & 16 & 72 & - \\
\hline 6 & $\begin{array}{c}\text { CASA Ouro } \\
\text { Verde }\end{array}$ & $\begin{array}{c}83 \\
\text { adolescentes }\end{array}$ & - & 83 & - & - \\
\hline 7 & $\begin{array}{c}\text { CASA Ribeirão } \\
\text { Preto }\end{array}$ & $\begin{array}{c}128 \\
\text { adolescentes }\end{array}$ & - & - & 128 & - \\
\hline 8 & CASA Rio Pardo & $\begin{array}{c}112 \\
\text { adolescentes }\end{array}$ & - & - & $\begin{array}{l}96 \text { em internação e } \\
16 \text { em } \\
\text { internação/sanção }\end{array}$ & - \\
\hline 9 & $\begin{array}{c}\text { CASA } \\
\text { Sertãozinho }\end{array}$ & $\begin{array}{c}88 \\
\text { adolescentes }\end{array}$ & - & - & 88 & - \\
\hline 10 & $\begin{array}{c}\text { NAI Ribeirão } \\
\text { Preto }\end{array}$ & $\begin{array}{c}5 \\
\text { adolescentes }\end{array}$ & 5 & - & - & - \\
\hline 11 & NAI São Carlos & $\begin{array}{c}2 \\
\text { adolescentes }\end{array}$ & 2 & - & - & - \\
\hline 12 & $\begin{array}{c}\text { CASA } \\
\text { Semiliberdade } \\
\text { Araraquara }\end{array}$ & $\begin{array}{c}20 \\
\text { adolescentes }\end{array}$ & & & & 20 \\
\hline 13 & $\begin{array}{c}\text { CASA } \\
\text { Semiliberdade } \\
\text { Barretos }\end{array}$ & $\begin{array}{c}20 \\
\text { adolescentes }\end{array}$ & & & & 20 \\
\hline 14 & $\begin{array}{c}\text { CASA } \\
\text { Semiliberdade } \\
\text { Batatais }\end{array}$ & $\begin{array}{c}56 \\
\text { adolescentes }\end{array}$ & - & 16 & 40 & - \\
\hline 15 & $\begin{array}{c}\text { CASA } \\
\text { Semiliberdade } \\
\text { Ribeirão Preto }\end{array}$ & $\begin{array}{c}20 \\
\text { adolescentes }\end{array}$ & - & - & - & 20 \\
\hline 16 & $\begin{array}{l}\text { CAIP Arcebispo } \\
\text { D. Hélder Câmara } \\
\text { - CAIP Franca }\end{array}$ & $\begin{array}{c}20 \\
\text { adolescentes }\end{array}$ & & & & 20 (república) \\
\hline
\end{tabular}




\begin{tabular}{|c|c|c|c|c|c|c|}
\hline \multicolumn{7}{|c|}{ DRL - DIVISÃO REGIONAL LITORAL (Praia Grande) } \\
\hline & UNIDADE & Internos & $\begin{array}{c}\text { Atendimento } \\
\text { Inicial }\end{array}$ & $\begin{array}{l}\text { Internação } \\
\text { Provisória }\end{array}$ & Internação & Semiliberdade \\
\hline 1 & CASA Peruibe & $\begin{array}{c}56 \\
\text { adolescentes }\end{array}$ & - & 16 & 40 & - \\
\hline 2 & CASA Mauá & $\begin{array}{c}56 \\
\text { adolescentes }\end{array}$ & - & 16 & 40 & - \\
\hline 3 & CASA Itanhaém & $\begin{array}{c}56 \\
\text { adolescentes }\end{array}$ & - & 16 & 40 & - \\
\hline 4 & CASA Mongaguá & $\begin{array}{c}56 \\
\text { adolescentes }\end{array}$ & - & - & 56 & - \\
\hline 5 & CASA Praia Grande I & $\begin{array}{c}56 \\
\text { adolescentes }\end{array}$ & - & 16 & 40 & - \\
\hline 6 & $\begin{array}{c}\text { CASA Praia Grande } \\
\text { II }\end{array}$ & $\begin{array}{c}56 \\
\text { adolescentes }\end{array}$ & - & 16 & 40 & - \\
\hline 7 & $\begin{array}{c}\text { CASA São Bernardo } \\
\text { I }\end{array}$ & $\begin{array}{c}56 \\
\text { adolescentes }\end{array}$ & - & 16 & 40 & - \\
\hline 8 & $\begin{array}{c}\text { CASA São Bernardo } \\
\text { II }\end{array}$ & $\begin{array}{c}56 \\
\text { adolescentes }\end{array}$ & - & - & 56 & - \\
\hline 9 & CASA Guarujá & $\begin{array}{c}72 \\
\text { adolescentes }\end{array}$ & - & 24 & 48 & - \\
\hline 10 & CASA V São Vicente & $\begin{array}{c}96 \\
\text { adolescentes }\end{array}$ & - & 24 & 72 & - \\
\hline 11 & NAI Santos & $\begin{array}{c}12 \\
\text { adolescentes }\end{array}$ & 12 & - & - & - \\
\hline 12 & $\begin{array}{c}\text { CASA Semiliberdade } \\
\text { Diadema }\end{array}$ & $\begin{array}{c}20 \\
\text { adolescentes }\end{array}$ & - & - & - & 20 \\
\hline 13 & CAIP Guarujá. & - & - & - & - & - \\
\hline
\end{tabular}




\begin{tabular}{|c|c|c|c|c|c|c|}
\hline \multicolumn{7}{|c|}{ DRO - DIVISÃO REGIONAL OESTE (Marilia) } \\
\hline & UNIDADE & Internos & $\begin{array}{l}\text { Atendimento } \\
\text { Inicial }\end{array}$ & $\begin{array}{l}\text { Internação } \\
\text { Provisória }\end{array}$ & Internação & Semiliberdade \\
\hline 1 & CASA Araçatuba & $\begin{array}{c}56 \\
\text { adolescentes }\end{array}$ & - & - & 56 & - \\
\hline 2 & CASA Irapuru I & $\begin{array}{c}56 \\
\text { adolescentes }\end{array}$ & - & 40 & 16 & - \\
\hline 3 & CASA Irapuru II & $\begin{array}{c}56 \\
\text { adolescentes }\end{array}$ & - & - & 56 & - \\
\hline 4 & CASA Mirassol & $\begin{array}{c}56 \\
\text { adolescentes }\end{array}$ & - & - & 56 & - \\
\hline 5 & $\begin{array}{l}\text { CASA São José Rio } \\
\text { Preto }\end{array}$ & $\begin{array}{c}88 \\
\text { adolescentes }\end{array}$ & - & 24 & 64 & - \\
\hline 6 & CASA Araçá & $\begin{array}{c}84 \\
\text { adolescentes }\end{array}$ & - & 24 & 60 & - \\
\hline 7 & CASA Marilia & $\begin{array}{c}88 \\
\text { adolescentes }\end{array}$ & - & 24 & 64 & - \\
\hline 8 & CASA Tanabi & $\begin{array}{c}56 \\
\text { adolescentes }\end{array}$ & - & 40 & 16 & - \\
\hline 9 & $\begin{array}{c}\text { CASA Rio Dourado - } \\
\text { Lins }\end{array}$ & $\begin{array}{c}120 \\
\text { adolescentes }\end{array}$ & - & - & 120 & - \\
\hline 10 & $\begin{array}{c}\text { CASA Vitória Régia - } \\
\text { Lins }\end{array}$ & $\begin{array}{c}72 \\
\text { adolescentes }\end{array}$ & - & 24 & 48 & - \\
\hline 11 & $\begin{array}{c}\text { CASA Semiliberdade } \\
\text { Fernandópolis }\end{array}$ & $\begin{array}{c}20 \\
\text { adolescentes }\end{array}$ & - & - & - & 20 \\
\hline 12 & $\begin{array}{l}\text { CASA Semiliberdade } \\
\text { São Jose Rio Preto }\end{array}$ & $\begin{array}{c}20 \\
\text { adolescentes }\end{array}$ & - & - & - & 20 \\
\hline 13 & $\begin{array}{c}\text { CASA Semiliberdade } \\
\text { Marília }\end{array}$ & $\begin{array}{c}20 \\
\text { adolescentes }\end{array}$ & - & - & - & 20 \\
\hline
\end{tabular}




\begin{tabular}{|c|c|c|c|c|c|c|}
\hline \multicolumn{7}{|c|}{ DRS - DIVISÃO REGIONAL SUDOESTE } \\
\hline & UNIDADE & Internos & $\begin{array}{c}\text { Atendimento } \\
\text { Inicial }\end{array}$ & $\begin{array}{l}\text { Internação } \\
\text { Provisória }\end{array}$ & Internação & Semiliberdade \\
\hline 1 & CASA Botucatu & $\begin{array}{c}56 \\
\text { adolescentes }\end{array}$ & - & 16 & 40 & - \\
\hline 2 & $\begin{array}{l}\text { CASA Feminino } \\
\text { Cerqueira Cesar I }\end{array}$ & $\begin{array}{c}56 \\
\text { adolescentes }\end{array}$ & - & 16 & 40 & - \\
\hline 3 & $\begin{array}{l}\text { CASA Feminino } \\
\text { Cerqueira Cesar II }\end{array}$ & $\begin{array}{c}56 \\
\text { adolescentes }\end{array}$ & - & - & 56 & - \\
\hline 4 & CASA Cerq Cesar III & $\begin{array}{c}56 \\
\text { adolescentes }\end{array}$ & - & 16 & 40 & - \\
\hline 5 & CASA Esperança & $\begin{array}{c}56 \\
\text { adolescentes }\end{array}$ & - & 16 & 40 & - \\
\hline 6 & $\begin{array}{c}\text { CASA Madre Teresa de } \\
\text { Calcutá I - Iáras }\end{array}$ & $\begin{array}{c}56 \\
\text { adolescentes }\end{array}$ & - & - & 56 & - \\
\hline 7 & $\begin{array}{c}\text { CASA Madre Teresa de } \\
\text { Calcutá II - Iáras }\end{array}$ & $\begin{array}{c}56 \\
\text { adolescentes }\end{array}$ & - & - & 56 & - \\
\hline 8 & CASA Bauru & $\begin{array}{c}88 \\
\text { adolescentes }\end{array}$ & - & 16 & 72 & - \\
\hline 9 & $\begin{array}{c}\text { CASA Rio Novo - } \\
\text { Iáras }\end{array}$ & $\begin{array}{c}2 \\
\text { adolescentes }\end{array}$ & -- & 24 & 48 & - \\
\hline 10 & $\begin{array}{c}\text { CASA Três Rios - } \\
\text { Iáras }\end{array}$ & $\begin{array}{c}120 \\
\text { adolescentes }\end{array}$ & - & - & 120 & - \\
\hline 11 & $\begin{array}{c}\text { CASA Semiliberdade } \\
\text { Bauru }\end{array}$ & $\begin{array}{c}20 \\
\text { adolescentes }\end{array}$ & - & - & - & 20 \\
\hline
\end{tabular}

\begin{tabular}{|c|c|c|c|c|}
\hline Internos & Atendimento Inicial & Internação Provisória & Internação & Semiliberdade \\
\hline 8.333 adolescentes & 59 & 2.337 & 5.357 & 560 \\
\hline
\end{tabular}

Obs.: Pelos dados do site da Fundação CASA nas regionais DRMC Campinas (unidade CASA Rio Piracicaba) faltam 04 internos e na unidade DRN Ribeirão (CASA Arcebispo D. Hélder Câmara - CASA Franca) faltam 16 internos - apresentados no número geral de internos, mas não indicados quanto a medida que cumprem. (faltando um total de 20 adolescentes).

JURISPRUDÊNCIA DO SUPERIOR TRIBUNAL DE JUSTIÇA 


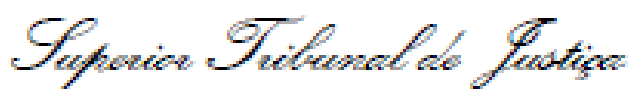

RECURSO ESPECIAL No 1.319.704 - RS (2012/0072660-6)

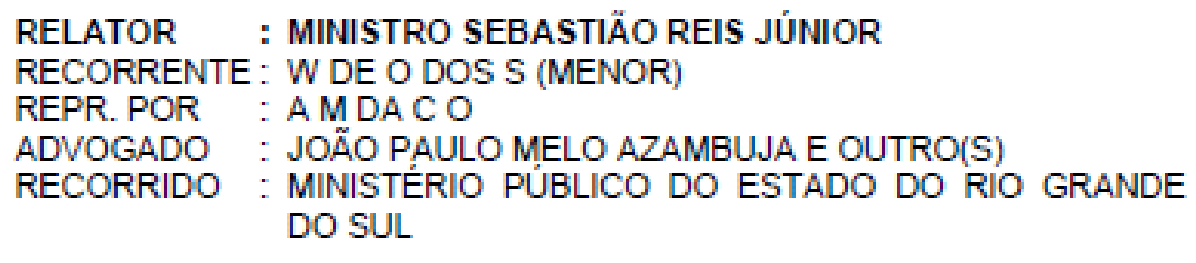

EMENTA

RECURSO ESPECIAL. DIREITO PENAL. LEI N. 8.069/1990. ESSTATUTO DA CRIANÇA E DO ADOLESCENTE. MEDIDA SÓCIOEDUCATIVA DE INTERNAÇÃO. ATO INFRACIONAL EQUIPARADO AO CRIME DE ESTUPRO. VIOLÊNCIA E GRAVE AMEAÇA A PESSOA. DECISÃO JUDICIAL FUNDAMENTADA. ACÓRDÄO A QUO EM CONȘONÂNCIA COM A JURISPRUDÊNCIA DESTE TRIBUNAL. SÚMULA 83/STJ.

Recurso especial improvido.

\section{DECISÃo}

Trata-se de recurso especial interposto por W DE O DOS S com fundamento no art. 105, III, a e c, da Constituição Federal, contra acórdão do Tribunal de origem que determinou a medida sócioeducativa de internação, com base no art. 122 da Lei n. $8.069 / 1990$ ao ora recorrente, sob o seguinte argumento (fl. 688):

\section{[...]}

Embora ○ representado não possua antecedentes, praticou ato infracional grave - estupro de vulnerável (art. 217-A do CP) - contra ofendida, sua prima, que possuía ao tempo das condutas infracionais apenas 7 anos de idade - e ainda restou acometida por doença transmitida nos atos sexuais.

Assim, e tratando-se de prática que se estendeu por quase meio ano, pelo voto da maioria, impóe-se a manutenção da aludida medida de internaçäo, a fim de que $\circ$ adolescente tome consciência da reprovabilidade social de sua conduta.

[...]

A ementa do acórdão estadual assim dispõe (fl. 688):

apelação cível. eca. ato infracional. estupro. autoria e materialidade confirmada. descabível a aplicaçäo de medida sOcioeducativa de internaçäo. cabimento. manutenção da medida. 


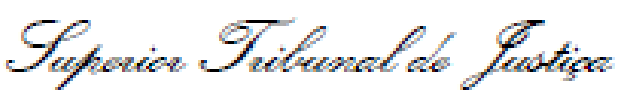

\section{Autoria}

A autoria foi comprovada pela prova oral colhida em juízo.

Materialidade

Boletim de ocorrência policia, pela entrevista psicológica da vítima, pela ficha de atendimento ambulatorial, pelo auto do exame de corpo de delito, pelo laudo psicológico da vítima e prova oral colhida em juízo que provam a respeito da materialidade do fato praticado.

Antecedentes.

Adolescentes sem antecedentes ou qualquer envolvimento em ato infracional anterior.

Análise dos antecedentes que deve atender os termos da Constituiçäo Federal.

Medida Socioeducativa

Embora o representado näo possua antecedentes, praticou ato infracional grave - estupro de vuinerável (art. 217-A do CP) - contra ofendida, sua prima, que possuía ao tempo das condutas infracionais apenas 7 anos de idade - e ainda restou acometida por doença transmitida nos atos sexuais.

Assim, e tratando-se de prática que se estendeu por quase meio ano. pelo voto da maioria, impõe-se a manutençäo da aludida medida de internaçäo, a fim de que $\circ$ adolescente tome consciência da reprovabilidade social de sua conduta.

Negaram PROVIMENTO, por maioria.

No recurso especial, além da ocorrência de dissidio jurisprudencial, a parte alega violação dos arts. $1^{\circ}, 3^{\circ}, 100,112, \S 1^{\circ}, 113,121$ e $122, \S 2^{\circ}$, da Lei n. 8.069/1990.

Aduz o recorrente que a medida socioeducativa de internação somente pode ser aplicada em circunstâncias excepcionais, diante dos efeitos nocivos da privação de liberdade (fi. 756).

Afirma que a medida socioeducativa aplicada ao adolescente é ilegal, porque não foi precedida de estudo psicossocial.

Requer, por fim, a cassação do acórdão local para que outra decisão seja prolatada aplicando outra medida socioeducativa em meio aberto (fil. 782).

Contrarrazões ofertadas, por meio das quais se sustenta a manutenção do acórdão recorrido (fls. 880/887). 


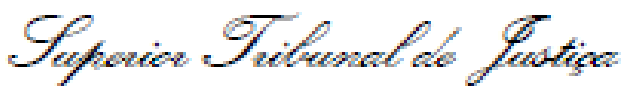

O Ministério Público Federal opinou pelo não provimento do recurso (fls. 907/910).

É o relatório.

Presentes os requisitos de admissibilidade, o recurso merece ser conhecido.

Prima facie, segundo Perseu Gentil Negrão, a finalidade do recurso especial é manter a uniformidade da lei federal, ou seja, velar para que a interpretação da norma federal seja realizada de forma idêntica em qualquer estado da Federação ou por qualquer órgão do Poder Judiciário (in Recurso Especial - Doutrina, Jurisprudência, Prática e Legislação. São Paulo: Saraiva, 1997, p. 5).

Fixada essa premissa, oportuna a transcrição da norma controvertida, art. 122 da Lei n. 8.069/1990 (ECA), que assim dispõe:

art. 122. A medida de internação só poderá ser aplicada quando:

1- tratar-se de ato infracional cometido mediante grave ameaça ou violéncia a pessoa;

III - por reiteraçäo no cometimento de outras infraçöes graves;

III - por descumprimento reiterado e injustificável da medida anteriormente imposta.

§ 10 O prazo de internaçäo na hipótese do inciso III deste artigo nåo poderá ser superior $\mathrm{a}-3$ (três) meses, devendo ser decretada judicialmente após o devido processo legal.

$\S 2^{\circ}$. Em nenhuma hipótese será aplicada a internação, havendo outra medida adequada.

Da exegese da norma supra, o Superior Tribunal de Justiça entende que a presença de violência na conduta do agente - ato infracional equiparado ao estupro de vítima com 7 (sete) anos - justifica a imposição da medida sociceducativa de internaçäo, nos termos do artigo 122 do ECA (AgRg no AREsp 60.919/PA, Rel. Ministro Vasco Della Giustina (Desembargador convocado do TJ/RS), Sexta Turma, DJe 22/2/2012)

De igual modo, julgado da Quinta Turma deste Tribunal: 
[...]

4. Estando a decisão judicial devidamente fundamentada, a aplicação de medida sócio-educativa de internação encontra amparo legal quando - ato infracional é cometido mediante violência e grave ameaça à pessoa, a teor do disposto no art. 122, inciso I, do Estatuto da Criança e do Adolescente.

5. Precedentes do Superior Tribunal de Justiça.

6. Ordem denegada.

(HC 78.341/RS, Rel. Ministra Laurita Vaz, Quinta Turma, DJ $29 / 8 / 2007)$

Logo, depreende-se dos autos que o acórdão recorrido se encontra em consonância com a jurisprudência assente do Superior Tribunal de Justiça, assim sendo, aplica-se ao caso vertente a Súmula 83/STJ.

No caso, a medida socioeducativa de internação é compativel com as circunstâncias concretas do ato infracional imputado ao ora recorrente, que praticou conjunção carnal e atos libidinosos contra sua prima, menor de idade (7 anos). Consta dos autos que a criança perdeu sua virgindade e resultou acometida de doença sexualmente transmitida (fl. 2).

Oportuna a transcrição da motivação disposta no voto condutor do acórdão recorrido, que, por maioria, negou provimento ao apelo da defesa (fls. 691/697):

[...]

Da medida socioeducativa.

Como se sabe, nos termos do art. 122, inciso I do ECA, internação deve ser a medida aplicada nos casos em que há violência ou grave ameaça à pessoa.

Tome-se em conta as circunstâncias do fato e ver-se-á que o roubo foi cometido com violência presumida, tendo em vista que a vítima possui, apenas, oito anos de idade.

Nesse passo, é licito dizer que as provas atestam que realmente ocorreu a conduta do representado. Logo, imperiosa a imposição de medida socioeducativa capaz de fazé-lo repensar seus atos.

Contudo, a internação é uma demasia, "data venia".

Com efeito, estou em que, no peculiar do presente caso a aplicaçäo de medida socioeducativa de internaçäo seja gravosa para além do que seja justo ao adolescente.

Vale a pena, começar por uma análise específica do que consta na certidäo de antecedentes.

Documento: 25141828 - Despacho / Decisalo - Ste certilicado - D.Je: 15/10/2012 Paglina 4 de 7 


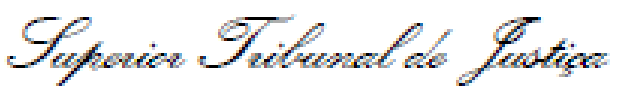

\section{Antecedentes.}

A certidão de antecedentes do adolescente (fl. 30) dá conta da existência de um único registro.

Registro este que se refere ao presente processo. Ou seja, ainda em andamento.

Portanto, numa leitura constitucionalmente adequada é lícito afirmar que o representado é primário e não possui nenhum antecedente.

Vale a pena salientar: aqui, não estamos diante de um adolescente que possui processos pendentes de julgamento por atos infracionais anteriores.

Quero dizer, este é o primeiro ato infracional, de qualquer espécie, em que $O$ adolescente está envolvido.

Ou seja, estamos aqui restringindo o direito fundamental à liberdade de ir e vir sem nenhuma previsảo legal, sem que se possa, sequer, alegar que a adolescente tenha uma conduta assídua de envolvimento em atos infracionais no passado.

Fundamentos para aplicação da prestação de serviços à comunidade cumulada com liberdade assistida.

Sem deixar de aplicar - caso a caso - a internação sem possibilidade de atividade externa, entendo que a medida de prestação de serviços à comunidade cumulada com liberdade assistida exerce - $\infty$ melhor efetividade em casos como presente - a tarefa de tentar a socialização e a educação dos infratores.

Repito, com isso não estou dizendo que näo se vai mais internar os infratores. São muitos os casos em que tenho confirmado decisőes determinando o internamento de infratores.

Estou, apenas, entendendo que a internação deve ser guardada para casos mais contundentes. Por isso que - vencido pela realidade - reservo a internaçäo para os casos em que - infelizmente - vou concordar em punir mais com o objetivo retributivo do que socializador.

Antes de entregar o adolescente para um Poder Executivo entendo que pode o Poder Judiciário guardar alguma forma de vigilância sobre os adolescentes com uso da prestação de serviços à comunidade cumulada com a liberdade assistida.

Veja-se que, aplicada tal medida, pode o juizo condenatório graduar da forma que melhor atender ao interesse de controle dos adolescentes a prestação de contas do sentenciado. Com efeito, o comparecimento ao Judiciário poderá ser até semanal.

E em caso de não cumprimento adequado da medida sempre haverá a possibilidade de regredir a medida. E aí entäo proceder ao internamento.

[...]

Des. Ricardo Moreira Lins Pastl (REVISOR)

Peço vênia para divergir parcialmente do nobre Relator. especificamente no que toca à medida socioeducativa aplicada, que tenho como adequada à espécie.

É que, embora o representado não possua antecedentes (fi. 30 ). praticou ato infracional grave - ectupro de vulnerável (art. 217-A do CP) - contra ofendida, sua prima, que possuía ao 


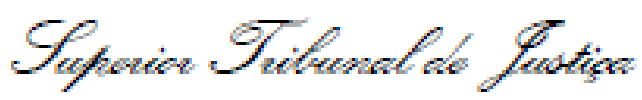

tempo das condutas infracionais apenas 7 anos de idade - e ainda restou acometida por doença transmitida nos atos sexuais.

Assim, e tratando-se de prática que se estendeu por quase meio ano. impõe-se a manutenção da aludida medida de intemação, a fim de que o adolescente tome consciência da reprovabilidade social de sua conduta.

[...]

Destarte, respeitosamente, voto no sentido de negar provimento ao apelo.

[...]

Em relação à procedència da representação, concordo com o colega Relator, pedindo vênia para divergir, täo somente, no que pertine à medida socioeducativa.

Friso que para além do caráter reeducador, existe sim a faceta punitiva das medidas aplicadas aos adolescentes, faceta esta que nảo deve ser esquecida em nome da Proteçäo Integral, uma vez que, a meu ver. Proteção Integral é respeitar o adolescente como sujeito de direitos e deveres, näo olvidando que a admissäo de tal qualidade passa pelo reconhecimento da responsabilizaçăo.

No caso dos autos, houve a prática de ato infracional com uso de violència contra a pessoa e, grave violência, não se perdendo de vista que a vitima é uma criança de apenas 07 (sete) anos de idade que. diante do comportamento do adolescente-infrator, teve lesões físicas e psicológicas sérias. No ponto, atento para o depoimento do médico atestando que vítima contraiu doença sexualmente transmissivel com contágio somente pelo ato sexual - fls. 223-224.

Além disso, as lesões psicológicas causadas à criança que é forçada a praticar ato sexual sem que esteja sequer com a sua capacidade de entendimento formada para tanto, é de gravidade incontestável.

Portanto, partindo da gravidade da conduta, destaco o disposto no artigo 112, $\S 1^{\circ}$, do Estatuto da Criança e do Adolescente, que preconiza que ao adolescente responsável pela prática de ato infracional, deve ser aplicada medida socioeducativa de acordo com as circunstâncias e a gravidade do ato infracional, devendo-se ter presente a necessária resposta do Estado à sociedade.

Assim, os adolescentes devem responder pelos atos infracionais que cometem de forma proporcional. Nesse sentido, ressalto que a medida socioeducativa de internação se presta ao caso em apreço, porquanto o adolescente cometeu ato infracional com uso de grave violência contra a vítima de apenas 07 (sete) anos de idade.

Logo, diante do contexto apresentado, nego provimento ao apelo.

[...]

Diante disso, não merece reforma o acórdão a quo.

O recurso não pode ser provido, outrossim, sob o fundamento da

alínea $c$, porque não realizou a parte o necessário cotejo analítico. Em outros Documento: 25141828 - Despacho / Decisalo - Site certillcado - D.Je: 15/10/2012

Paglna 6 de 7 


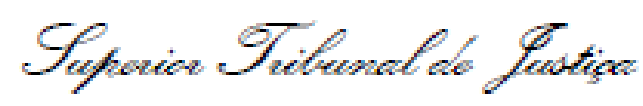

termos, in casu, não se demonstrou suficientemente as circunstâncias identificadoras da divergência com o caso confrontado, conforme dispõem os arts. 541, do Código de Processo Civil; e 255, $\S \S 1^{\circ}$ e $2^{\circ}$, do Regimento Interno do STJ.

Confira-se: REsp 839.147/PR, Rel. Ministra Maria Thereza de Assis Moura, Sexta Turma, DJe 3/8/2009.

Sendo repetidamente decidida a matéria debatida, conforme os precedentes citados, o presente recurso comporta pronta solução, nos moldes do art. 557, caput, $\S 1^{\circ}-\mathrm{A}$, do Código de Processo Civil, c/c 0 art. $3^{\circ}$ do Código de Processo Penal, com o fim de se agilizar a prestação jurisdicional.

Ante o exposto, com fulcro nos arts. 28 da Lei n. 8.038/1990, 34 do Regimento Interno/STJ e 557, caput, $\S 1^{\circ}$-A, do Código de Processo Civil, nego provimento ao recurso especial.

Publique-se.

Brasília, 09 de outubro de 2012.

\section{Ministro Sebastião Reis Júnior}

Relator 


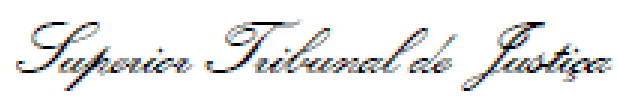

HABEAS CORPUS N ${ }^{\circ} 224.583$ - SP (2011/0269500-4)

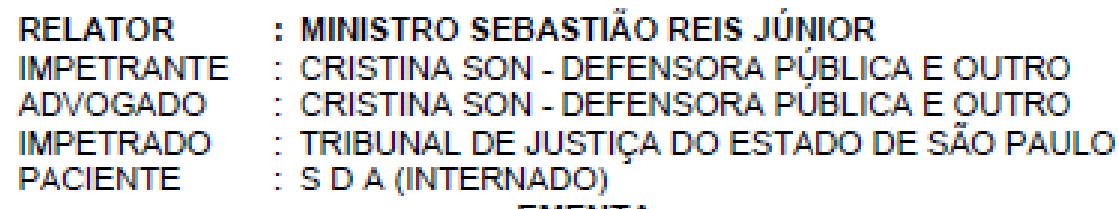

EMENTA

HABEAS CORPUS. ECA. MEDIDA DE INTERNAÇÃO. NECESSIDADE DE TRATAMENTO AMBULATORIAL. MEDIDA DE CARÁTER MERAMENTE RETRIBUTIVO. ILEGALIDADE.

- Ordem concedida para que a paciente seja inserida na medida socioeducativa de liberdade assistida, associada ao acompanhamento ambulatorial psiquiátrico, psicopedagógico e familiar.

\section{DECISÃo}

Trata de habeas corpus impetrado em benefício de S D A, apontando-se como autoridade coatora a Câmara Especial do Tribunal de Justiça de São Paulo, que denegou $\circ$ Habeas Corpus $\mathrm{n}$. 0113179-29.2011.8.26.0000 (fi. 402):

HABEAS CORPUS - Decisão que indeferiu a modificação da medida aplicada à adolescente, mantendo a internaçäo, a despeito do relatório técnico sugerir a progressão da medida - Os laudos não vinculam o magistrado - Inadmissibilidade de habeas corpus para reformar decisão. visto que nảo se presta a substituir o recurso próprio - Decisảo mantida Ordem denegada.

Alega a impetrante que a paciente já está internada há mais de 2 anos "em decorrência de sentença judicial que determinou sua internação, em razão da prática de ato infracional equiparado ao crime de tráfico de drogas". Argumenta que o laudo técnico da Fundação Casa, onde está a menor intemada, concluiu pela possibilidade de progressão da paciente para a medida socioeducativa de liberdade assistida, tendo em vista possuir distúrbio de conduta, com sintomas de auto flagelação, agressividade, alucinações visuais e auditivas, irritabilidade excessiva, dentre outros, sendo que o quadro 


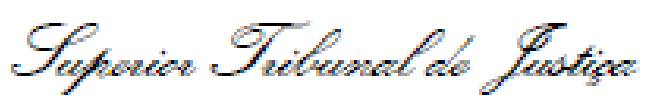

é agravado em razão das condições ambientais, nas quais está inserida, concluindo-se que 0 estado de saúde da paciente justifica as faltas disciplinares constantes em seu prontuário (fl. 2). Pleiteia que a adolescente seja encaminhada "a um atendimento individual e especializado, compativel com sua limitação mental, de acordo com o $\S 3^{\circ}$, do art. 112 do ECA" (fl. 7).

Requereu a concessão de liminar para extinguir a medida de intemação, com a colocação da paciente em liberdade e sua inserção em medida de proteção pertinente, qual seja, o tratamento ambulatorial psiquiátrico, psicopedagógico e familiar.

Deferi a liminar (fls. 412/416).

No mérito, objetiva a confirmação da liminar, substituindo-se a medida de intemação pela liberdade assistida, acompanhada do tratamento ambulatorial.

O Ministério Público Federal emitiu parecer pela concessão da ordem (fls. 427/430).

\section{É o relatório.}

O intuito da medida socioeducativa, em qualquer de suas modalidades, é o de educação e ressocialização do menor infrator. Sua aplicação é realizada de acordo com o caso que se apresenta, sendo consideradas as circunstâncias da prática do ato infracional (objetivas) e as condições pessoais do menor infrator (subjetivas). Reavaliações periódicas são realizadas com a finalidade de verificação da efetividade da medida imposta.

In casu, a menor já está submetida a medida de internação há mais de 2 anos.

Examinando os presentes autos, verifico que os laudos técnicos 


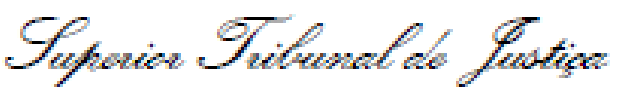

apresentados pela instituição onde está a paciente recolhida, em 16/3/2011 e $22 / 8 / 2011$ (fls. 334/380), foram favoráveis à extinção da medida de internação e aplicação do tratamento ambulatorial. Do último laudo apresentado, extraio as seguintes passagens, que considero relevantes (fls. 375/381):

"A Sra. A., genitora de S. continua participando de forma ativa nas ações propostas pela equipe para reorganização pessoal de sua filha. Nesse sentido, participa das consultas psiquiátricas de $\mathbf{S}$. realizadas na rede de saúde de Tatuí/SP para aumentar sua percepção e responsabilidade sobre as vivências de sua e filha e sobre as perspectivas que visualizam para quando for encerrado o período de privaçäo de liberdade"

[...] O estado de saúde da Sra. C. S., avó de S, ainda é delicado. diante da instabilidade e fragilidade de seu quadro clínico, em decorrência da própria idade avançada, agravado por complicaçöes pulmonares e do sistema circulatório ocasionando lesões em suas pernas. Tal fato, também gera maior sobrecarga emocional em $\mathbf{S}$., já que possui forte vinculação afetiva com a Sra. C. Como atenuante para o núcleo familiar de $\mathbf{S}$. em MaracaíSP é que a avó dispõe de casa própria para moradia, recebe pensão de seu ex-marido para o seu próprio sustento"

[...] a sobrecarga gerada pelo tempo de internação, trazendo paralelo inúmeras variáveis da rotina e dinâmica institucional enquanto agravantes para uma melhor resposta na internação, impedem sua melhor organização e expressäo pessoal.

Do seu contexto familiar é de onde surgem seus maiores temores acentuando seu desgaste psíquico gerado pela privaçäo da liberdade. Nesse sentido, $\mathbf{S}$. manifesta claramente expressiva desorganização em relação ao distanciamento de pessoas afetivas e próximas de sua convivência, como sua avó materna e sua própria genitora. Recentemente, o falecimento do Sr. M., namorado de sua genitora, com - qual S. mantinha grande vinculação afetiva, provocou uma desorganização pessoal prejudicando o sustento dos progressos até então observados, mesmo considerando que esteja vinculada a Etapa III do Projeto Pedagógico vigente na Unidade.

Tendo consciència de toda sua trajetória institucional com claras dificuldades para alcançar e sustentar sua estabilidade emocional, S. carrega consigo uma sensação de falência pessoal, não conseguindo mais visualizar e nem sustentar de fato uma perspectiva dentro da própria internaçäo que lhe traga maior satisfação de vida, a não ser a de permanecer o tempo máximo da Medida Socioeducativa. Esse aspecto tem sido permanentemente trabalhado com $\mathbf{S}$. para que considere $e$ reformule ainda vinculada à internação seus conceitos e práticas de vida dentro dessa renovada trajetória em sua evolução que pode ser redefinida, $O$ desgaste emocional associado à falta de perspectiva dentro da internação säo retratados em alguns momentos, revelando alguma resistência à terapia medicamentosa, demonstrando não mais acreditar 
por vezes nos benefícios de qualquer iniciativa da equipe para essa sua reorganizaçäo pessoal. Sinaliza, no entanto, que muito conseguiu reformular na sua forma de lidar com suas dificuldades de vida, na percepção de si própria, nas suas formas de atuaçäo, no respeito ao outro, mesmo que muitas vezes de forma limitada, $\mathbf{S}$. reconhece o aprendizado, adquirido em todo tempo da internaçäo $e$ tem procurado renovar sua disposição pessoal para novos aprendizados, sendo exemplo disso a própria aceitação nesse momento da psicoterapia. Nesse sentido, o tempo dilatado privada da liberdade pouco tem contribuido para sua melhor expressão pessoal (fl. $377 / 378$ ).

[...]

$S$ é um caso mais de atenção à saúde mental que se sobrepõe ao próprio ato infracional, consequência de sua falência e desorganizaçäo pessoal registrada em período anterior a sua privação da liberdade.

Nesse sentido, a equipe continua direcionando seus investimentos para sua reorganizaçäo pessoal, nas suas bases, afetiva e emocional, por meio da continuidade dos atendimentos psiquiátricos, em seu município de residência e psicológicos no Centro de Saúde de Cerqueira César, além das próprias açóes da equipe multidisciplinar.

Dessa forma, daremos continuidade às metas propostas para esse próximo período de privação da liberdade de $\mathrm{S}$. Acreditamos que tendo neutralizado as variáveis da rotina e dinâmica institucional pela sua desinternaçäo, que acentuam sua sobrecarga emocional, consiga efetivar e sustentar um tratamento a nivel ambulatorial em seu município de residencia, dispondo para isso do apoio de sua genitora que tem se mostrado presente, atuante e com disposição para alcançar melhores resultados em todas as etapas propostas para internaçäo de $\mathbf{S}$.

A decisão do Magistrado de primeiro grau, que indeferiu o pedido de extinção da medida de internação, está fundamentada, apenas, na existência de faltas disciplinares cometidas pela paciente e no entendimento de que a liberdade da paciente iria prestigiar a sua desobediência (fl. 344).

O acórdão impugnado, por sua vez, denegou o writ originário, considerando que o magistrado não está vinculado ao laudo técnico e que a análise dos requisitos necessários para a progressão da medida demandaria dilação probatória, incompativel com via do habeas corpus .

As faltas disciplinares cometidas pela menor, utilizadas na fundamentação do indeferimento do pedido de extinção da medida de intemação pelo juízo de primeiro grau, não são razão suficiente, em minha 


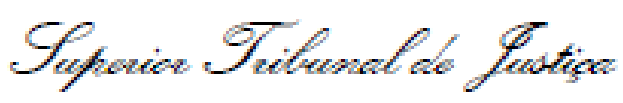

compreensão, a justificar a permanência em medida considerada ineficaz.

Entendo que os fundamentos contidos nas decisões impugnadas não afastam, em nenhum momento, a conclusão do laudo técnico, no sentido de que a medida de internação, que já perdura por mais de 2 anos, não traz, na atual fase, progresso à paciente, que não mais assimila os beneficios da medida aplicada, necessitando, na verdade, do tratamento ambulatorial, bem como o estreitamento dos seus vínculos familiares. A propósito, confira-se o precedente desta Corte:

HABEAS CORPUS. PROCESSO PENAL. ESTATUTO DA CRIANCA E DO ADOLESCENTE. RETARDO MENTAL LEVE. TRATAMENT́O PSIQUIÁTRICO. NECESSIDADE. MEDIDA SOCIOEDUCATIVA DE INTERNAÇÄO. CARÁTER MERAMENTE RETRIBUTIVO. ILEGALIDADE. ORDEM CONCEDIDA.

1. Nos termos do $\S 1^{\circ}$ do art. 112 do ECA, a imposição de medida socioeducativa deverá considerar a capacidade de seu cumprimento pelo adolescente, no caso concreto.

2. O paciente näo possui capacidade mental para assimilar a medida socioeducativa, que, uma vez aplicada, reveste-se de caráter retributivo. o que é incompativel com os objetivos do ECA.

3. Ordem concedida para determinar que o paciente seja inserido na medida socioeducativa de liberdade assistida associada ao acompanhamento ambulatorial psiquiátrico, psicopedagógico e familiar.

(HC 88043/SP, Ministro Og Fernandes, Sexta Turma, DJe 04/05/2009).

Por fim, constatada a a superveniência de distúrbio mental, a medida de internação passa a ter caráter meramente retributivo diante da incapacidade da paciente em assimilar sua finalidade, devendo a paciente, nessa situação, ser submetida a medida compativel com suas necessidades e restrições. No mesmo sentido:

CRIMINAL. HC. ECA. ADOLESCENTE PORTADOR DE TRANSTORNO DE PERSONALIDADE ANTI-SOCIAL. INTERNAÇÃO COM DETERMINAÇÃO DE TRATAMENTO DENTRO DA UNIDADE DA FEBEM. INADEQUAÇÄO. OFENSA AO PRINCÍPIO DA LEGALIDADE. ORDEM CONCEDIDA.

I. Hipótese em que, diagnosticado no adolescente o transtorno de personalidade anti-social (PAS), foi mantida a medida sócio-educativa de internação com a determinaçäo de tratamento psiquiátrico na mesma unidade em que se encontra segregado.

II. O adolescente que apresenta distúrbio psiquiátrico não pode ficar submetido a uma medida sócio-educativa diante de sua Documento: 19147244 - Despacho / Decisalo - Ste certiflcado - DJe: 06/12/2011 Pagina 5 de 6 


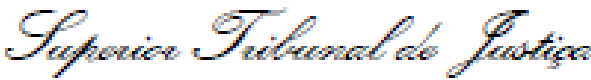

inaptidão para cumpri-la (art. 112, $\S 1^{\circ}$, do ECA).

III. Se o processo sócio-educativo imposto ao paciente - com finalidade ressocializadora - não se mostra apto à resolução de questōes psiquiátricas, faz-se necessária a implementação de uma das medidas protetivas dispostas na lei, com a submissão do adolescente a um tratamento adequado à sua doença ou deficiência mental.

IV. A imposição do regime de internação ao paciente, com a determinação de realização de psicoterapia dentro da Unidade da Febem ofende o Princípio da Legalidade.

$V$. Deve ser determinada a inserção do menor em medida sócio-educativa de liberdade assistida, com a sua submissão imediata a tratamento psiquiátrico devido em local adequado ao transtorno mental apresentado.

Vl. Ordem concedida, nos termos do voto do Relator.

(HC 60.604 - SP, Ministro Gilson Dipp, Quinta Turma, DJe 19/03/2007)

Ante o exposto e na linha do parecer do Ministério Público Federal, concedo a ordem para confirmar a liminar já deferida, inserindo a paciente na medida socioeducativa de liberdade assistida associada ao acompanhamento ambulatorial psiquiátrico, psicopedagógico e familiar, nos termos da fundamentação acima.

Publique-se.

Brasilia (DF), 30 de novembro de 2011

Ministro Sebastião Reis Júnior

Relator 


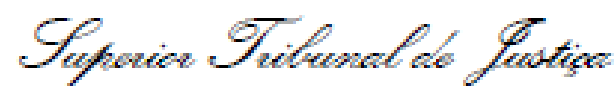

HABEAS CORPUS $\mathrm{N}^{\circ} 114.859$ - DF (2008/0195498-6)

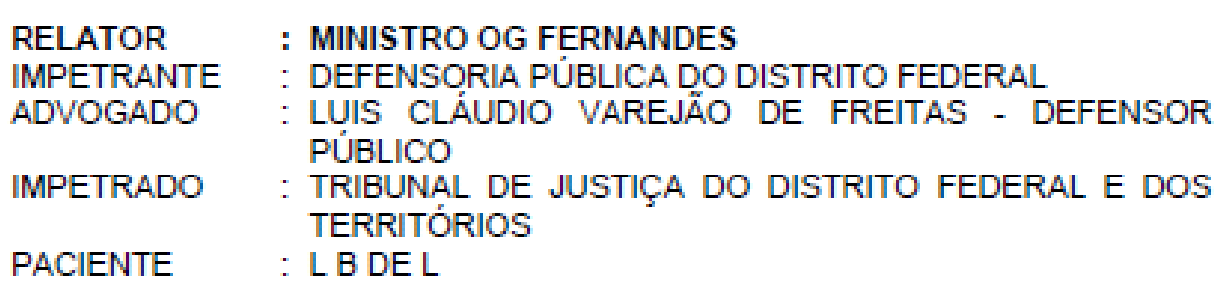

\section{DECISÄO}

Trata-se de habeas corpus impetrado em favor de L. B. de L., apontando como autoridade coatora o Tribunal de Justiça do Distrito Federal e dos Territórios, que dando provimento ao recurso de apelação interposto pelo Ministério Público, determinou a aplicação de medida sócio-educativa de semiliberdade ao paciente, em razão da prática de ato infracional análogo ao crime previsto no art. 14, caput, da Lei $n^{\circ} 10.826 / 03$.

Busca a impetração, ver reconhecida a nulidade do acórdão, por falta de fundamentação suficiente quanto à aplicação da medida sócio-educativa de semiliberdade, acentuando que 0 ato infracional em questão não envolveu violência ou grave ameaça, bem como não haver reiteração no cometimento de outras infraçôes graves, visto que o paciente possui apenas duas passagens pela Vara da Infấncia e da Juventude.

Indeferida a liminar e prestadas as informaçöes, a Subprocuradoria-Geral da República apina pela concessão da ordem.

Com razão o parecer ministerial.

O Juizo de primeiro grau assim se manifestou, no que interessa (fls. 24/25):

"Em relaçäo ao contexto pessoal e social do adolescente, observa-se que L. conta com 17 (dezessete) anos de idade e registra duas outras passagens em sua folha de antecedentes infracionais, pela prática de atos análogos a roubo e danos, sendo que no Processo $n^{\circ}$ 3004-6/07 foi aplicada a medida sócio-educativa de liberdade assistida $\mathrm{c} / \mathrm{c}$ a medida sócio-educativa de serviço à comunidade, sentença em 01/07/2007.

Segundo as informações constantes do relatório técnico avaliativo do CESAMI, fls. 44/45, L. apresentou boa adaptação ao cumprimento da internação provisória, possui participação ativa nas atividades propostas e acata as normas e regras sem dificuldade, demonstrando que pode retornar ao convivio familiar e à sociedade, mediante trabalho significativo que o reconduza ao retorno à educaçäo formal, à preparação para o trabalho, visando à retomada da auto-estima e a ocupaçảo do seu tempo de forma construtiva. A equipe técnica do CESAMI sugere a aplicação das medidas sócio-educativas de liberdade assistida cumulada com a prestaçäo de serviços à comunidade, além da medida protetiva prevista no art. 101, III, do Documento: 4361039 - Despacho / Declis5o - Sthe certitlcado - DJe: 30/10/2008 


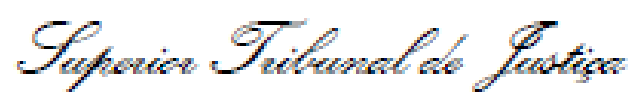

ECA.

Assim, verifica-se que o jovem está a precisar de uma orientaçäo mais adequada, de forma que possa modificar sua conduta, sendo incentivado a buscar a profissionalizaçäo por meio de cursos, bem assim retornar aos estudos.

Observa-se que a medida de semiliberdade proposta pelo representante do Ministério Público mostra desproporcional ao ato infracional praticado, pois recentemente forma determinadas as medidas de liberdade assistida e a de prestação de serviço à comunidade não sendo o tempo suficiente para aferir a sua eficácia.

Da mesma forma, ainda que reprovável o ato infracional, este näo foi praticado mediante violência ou grave ameaça à pessoa. Ademais, o próprio relatório do CESAMI informa ser salutar ao processo de ressocialização o retorno de $L$. ao meio social a que pertence.

Desse modo, visiumbrando-se que a medida sócio-educativa de liberdade assistida é suficiente ao processo de ressocialização do jovem, não se mostrando, porém, necessária à privaçäo de liberdade para o seu processo de reeducação."

O Tribunal de origem fundamentou a necessidade da medida de semiliberdade nos seguintes termos:

"A medida sócio-educativa visa reintegrar o menor na sociedade e no meio familiar, bem como fornecer subsidios para alterar 0 comportamento e buscar conduta social correta, dando-lhe perspectivas de redimencionar seu papel na familia e também na comunidade. Deve guardar proporção com a gravidade do ato infracional, observadas as circunstâncias judiciais e as condiçōes pessoais.

O ato cometido pelo adolescente é grave, apesar de näo ter sido cometido com violência ou grave ameaça. O infrator foi abordado pelo SDPM José Rafael em uma festa no Setor Norte de Brazlândia/DF, por volta da $1 \mathrm{~h}$ da manhã. O policial relatou que o jovem, acompanhado de três individuos, apresentava atitude suspeita. Feita a abordagem, encontrou o revólver, marca Rossi, calibre 22, carregado, na cintura do menor.

No interrogatónio, afirmou que 'comprou a arma para se mostrar'; tem 17 anos; näo está estudando; também näo trabalha; comprou a arma descrita por R\$ 220,00 na feria do rolo; conseguiu o dinheiro com a compra da arma em decorrência de um roubo que havia feito antes.' Como ressalvado pelo Ministério Público sobre o delito de porte ilegal de arma, ' a partir da entrada em vigor do Estatuto do Desarmamento (Lei $n^{\circ}$ 10.826, de 22 de dezembro de 2003), passou a receber tratamento bem mais severo, estando agora o agente infrator sujeito a pena que varia de 02 (dois) a 4 (quatro) anos de reclusäo e multa, sendo ainda tal crime inafiancável (...) embora se cuide de comportamento perpetrado sem violência ou grave ameaça contra a 


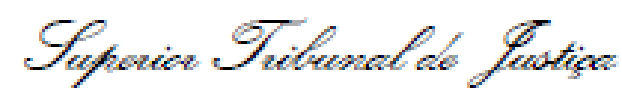

pessoa, isto näo afasta a sua potencialidade perigosa, gerando imensa preocupação social. Afinal, tendo sido amplamente noticiado pela mídia que a proliferação de armas clandestinas nas mãos de pessoas despreparadas e inexperientes, tal como o apelante, vem contribuindo decisivamente para o recrudescimento dos índices de violência (...)' (fl. 93).

Verifico que possui outras passagens pela Vara da Infância e Jiventude, o que demonstra personalidade voltada para a prática de atos infracionais. Além do mais, já foi beneficiado pelo instituto da remissäo como forma de exclusão do processo e por medida mais branda - liberdade assistida. Näo aproveitou as oportunidades e voltou a delinqüir. $O$ apenado necessita recuperar-se. A liberdade assistida näo traria o mesmo efeito ao adolescente que possui outras passagens registradas e envolveu-se em novo ato infracional. Só cria a idéia de impunidade.

Ademais, conforme consta dos relatórios do CESAMI às fls. 46/52, o adolescente evadiu-se da escola há dois anos, quando expulso por uso de entorpecentes. Relata que iniciou as práticas delituosas aos 12 anos de idade. Acrescenta que 'sozinho, não conseguirá exercer outra posição no contexto social pela vulnerabilidade às influências negativas do meio social que reside' e que 'a familia parece não assumir papel de autoridade, impondo os limites necessários ao mesmo."

(...)

Mais correta a aplicaçäo da medida sócio-educativa de semiliberdade, por prazo indeterminado." (fils. 33/35)

Não me parece que os fundamentos apresentados pelo acórdão impugnado sejam suficientes para desconstituir a decisão do primeiro grau.

No caso, o regime de semiliberdade imposto ao paciente viola o princípio da proporcionalidade, porquanto $o$ ato infracional não foi praticado com violência ou grave ameaça, e o Relatório do CESAMI - Centro Socioeducativo Amigoniano, a que se refere o Tribunal de origem, sopesando todas as condiçōes pessoais e sociais do menor, sugeriu a aplicação da medida de liberdade assistida.

De outra parte, nos termos do artigo $120, \S 2^{\circ}$, do ECA, as disposições referentes à medida sócio-educativa de internação aplicam-se, no que couber, à de semiliberdade.

Assim, os antecedentes considerados pela Corte a quo (roubo e danos) não justificam a adoção da referida medida, visto que não preenchido $\circ$ requisito quantitativo reconhecido pela jurisprudência dominante, no sentido de que somente ocorre reiteração de conduta infracional pelo menor, quando, no mínimo, são praticadas três ou mais condutas infracionais.

Vejam-se os precedentes:

"CRIMINAL. HC. ECA. ATO INFRACIONAL EQUIPARADO A TENTATIVA DE ROUBO QUALIFICADO. LIBERDADE ASSISTIDA. PRESTAÇÃOO DE SERVIÇOS ACOMUNIDADE. APELAÇÃO 


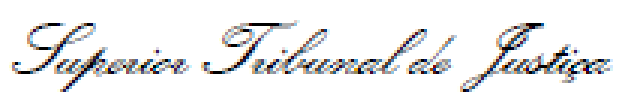

MINISTERIAL. SEMILIBERDADE. GRAVIDADE DO ATO. IMPOSIÇÃO DE MEDIDA ANTERIOR POR ATO INFRACIONAL EQUIVALENTE A FURTO. FUNDAMENTAÇÃ̈O INSUFICIENTE. AFRONTA AOS OBJETIVOS DO SISTEMA. CONSTRANGIMENTO ILEGAL CONFIGURADO. ORDEM CONCEDIDA.

Hipótese em que ao paciente foi imposta medida sócio-educativa de liberdade assistida, cumulada com prestação de serviços à comunidade, pela prática de ato infracional equiparado ao delito de tentativa de roubo qualificado, sendo que, em sede de apelação ministerial, foi fixada a medida de semiliberdade.

Ausência de fatos concretos necessários a justificar imposição da medida mais gravosa, ficando a semiliberdade baseada na gravidade do delito praticado, bem como no fato de já ter sido imposta ao paciente medida anterior.

A simples alusäo à gravidade do ato infracional näo se presta a embasar sequer a medida sócio-educativa de internação, eis que constitui motivação genérica que não se presta para fundamentar a medida mais gravosa, até mesmo por sua excepcionalidade, restando caracterizada a afronta aos objetivos do sistema.

A anterior prática de ato infracional equivalente ao crime de furto não caracteriza reiteração de infraçōes graves, tanto que näo se verifica a presença de violência ou grave ameaça à pessoa, afigurando-se desproporcional a imposição de semiliberdade.

Afronta aos objetivos do sistema caracterizada.

Magistrado singular que ressaltou o fato de que desde a liberação do paciente, ocorrida trés meses antes da decisão final, näo se vislumbrou seu envolvimento em novas práticas infracionais, além de que estaria recebendo assistência familiar.

Deve ser cassado o acórdão recorrido, para restabelecer a medida de liberdade assistida cumulada com prestaçäo de serviços à comunidade imposta pelo Juizo singular.

Ordem concedida, nos termos do voto do Relator." ( HC $n^{\circ} 70499 / \mathrm{SP}$, Relator o Ministro GILSON DIPP, DUU 25/06/2007)

"ESTATUTO DA CRIANÇA E DO ADOLESCENTE ATO INFRACIONAL ANÁLOGO AO TRÁFICO DE ENTORPECENTES. APLICAÇÃO DA MEDIDA SÓCIO-EDUCATIVA DE SEMILIBERDADE. GRAVIDADE GENERICA DO ATO INFRACIONAL. MOTIVAÇÄOO INIDÓNEA. FALTA DE APRECIAÇÃO DAS CONDIÇŌ̇ES PESSOAIS DO MENOR. OBJETIVOS DO ESTATUTO DESATENDIDOS. ORDEM CONCEDIDA.

1. A imposiçäo de medida de semiliberdade sem motivação idônea, porque não consideradas, de forma concreta, as circunstâncias e a gravidade do ato infracional, bem como as condiçöes pessoais do adolescente em conflito com a lei, não atende à finalidade precipua da Lei $8.069 / 90$, que é conferir proteçäo integral à criança e ao 


\title{
Serperiar Sibunal alo fustica
}

\begin{abstract}
adolescente
2. Ordem concedida para anular acórdäo, apenas no que se refere à medida sociceducativa de semiliberdade, a fim de que outra seja aplicada ao paciente, que deverá aguardar em liberdade assistida." (HC $n^{\circ} 62.889 / S P$, Relator o Ministro ARNALDO ESTEVES LIMA, DJU $28 / 05 / 2007)$
\end{abstract}

Impõe-se notar, ainda, que o Juízo monocrático, por estar mais perto dos fatos e ter acesso a todos os documentos, reúne, na maioria das vezes, melhores condições de adequar a medida sócio-educativa à situação do menor.

Dessarte, concedo a ordem de habeas corpus para, anulando o acórdão recorrido, restabelecer a sentença condenatória de primeiro grau.

Publique-se.

Intime-se.

Brasília (DF), 23 de outubro de 2008 .

MINISTRO OG FERNANDES, Relator 


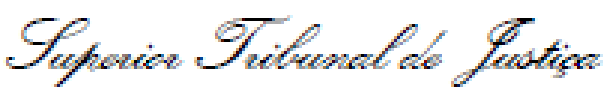

HABEAS CORPUS N॰ 82.606 - MS (2007/0105140-1)

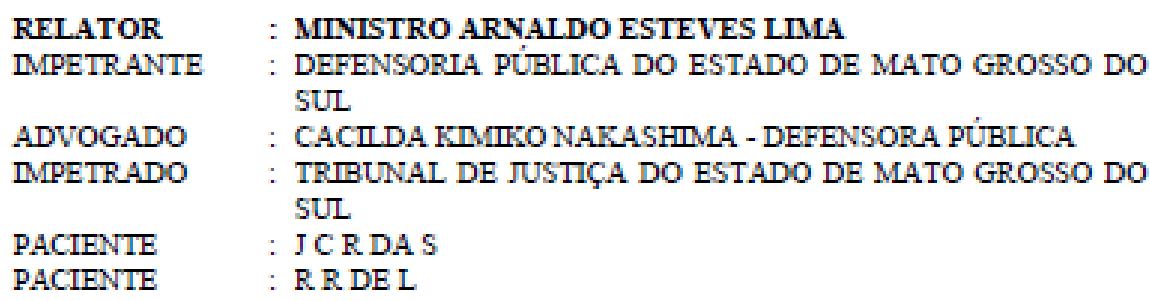

\section{DECISÃo}

Trata-se de habbas corpus, com pedido liminar, impetrado em favor de dois menores infratores - inseridos na medida socioeducativa de internação sem prazo determinado, pela prática de ato infracional equiparado ao delito de furto qualificado.

Insurge-se a impetrante contra acórdão da Segunda Turma Criminal do Tribunal de Justiça do Estado de Mato Grosso do Sul que negou provimento ao apelo defensivo (AC $2006.016847-2 / 00$ ), cujo objetivo era a absolvição ou, alternativamente, o afastamento do decreto de internação por prazo indeterminado.

Sustenta a impetrante que as hipóteses que autorizam a aplicação da medida socioeducativa com privação de liberdade a adolescente infrator são taxativamente listadas no art. 122 do Estatuto da Criança e do Adolescente, não incluindo o delito de furto, o qual não possui a elementar de violência ou de grave ameaça à pessoa no tipo penal.

Aduz, ainda, que não há falar em reiteração delitiva no cometimento de outras infrações graves, nem tampouco foi descumprida medida anterionnente imposta, sem a necessária comprovação do alegado.

Requer a concessão de medida liminar para que, desde logo, seja autorizado que os pacientes aguardem em liberdade o julgamento do mérito do presente urit $e$, no mérito, a concessão da ordem para cassar o acórdão impugnado e a decisấo singular que determinou a medida extrema.

Passo a decidir.

Tenho defendido, em diversas oportumidades, que o pedido formulado em sede de cognição sumária não deve ser deferido por relator quando a pretensão confunde-se com o mérito da impetração, tendo em vista que a liminar, em sede de haboas corpus, de competência originária de tribunal, como qualquer outra medida cautelar, deve restringir-se à garantia da eficácia da decisão final a ser proferida pelo órgão competente para o julgamento, quando, evidentemente, fizerem-se presentes, simnltaneamente, a plausibilidade juridica do pedido e o risco de lesão grave ou de difícil reparação.

No caso, a decisão de primeiro grau de jurisdição impôs medida de internação por prazo indeterminado pelos seguintes fundamentos, os quais foram confirmados pelo Tribunal a quo (fl. 26):

Assim, considerando-se os fatos praticados nestes autos e a vida pregressa dos representados, entendo com suficiente e adequada no presente caso a aplicação de medida sócio-educativa de internação por prazo indeterminado, devendo durar enquanto conveniente is finalidades de medida, e reavaliada a cada trés meses, cuidando-se sempre da educação regular e profissional do representado..."

Diante desses elementos, penso que se encontra presente a plausibilidade juridica do pedido, na medida em que a Quinta Turma deste Tribunal, competente para o julgamento 


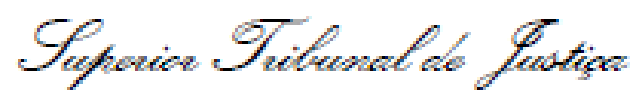

do mérito deste writ, decidiu na sessão realizada no dia 4/11/04, apreciando pedido de habbeas conpus substitutivo de recurso ordinánio (HC $35.658 / R$ ), interposto contra acórdão proferido pela Segunda Câmara Criminal do Tribunal de Justiça do Estado do Rio de Janeiro (HC 2004.059.00804), que, nos termos da legislação de regência, a medida de internação só poderá ser aplicada quando se tratar de ato infracional cometido mediante grave ameaça ou violência à pessoa, por reiteração no cometimento de outras infrações graves ou por descumprimento reiterado e injustificável de medida anteriormente imposta. Portanto, não se aplica aos casos em que a representação é pela prática de ato infracional análogo ao crime de furto qualificado, por ser infração cometida sem violência ou grave ameaça à pessoa, não havendo a demonstração concreta de qualquer das hipóteses elencadas no rol do art. 122 da Lei $8.069 / 90$.

Ademais, havendo o descumprimento injustificável da medida de liberdade assistida, impostas em razão da prática de ato infracional análogo ao delito previsto no art. 159 , § $1^{\circ}$, do Código Penal a regressão deve observar "o prazo máximo de três meses, ínsito no art. $122, \S 1^{\circ}$, do ECA, o qual desrespeitado, enseja constrangimento ilegal" (HC 31.744/SP, Rel. Min. GIL.SON DIPP, Quinta Turma, DI de 2/8/04).

Diante desses elementos, a plausibilidade juridica do pedido dispensa maiores comentários, uma vez que a aplicação da medida sócio-educativa à paciente afronta a legislação de regência, sendo certo afirmar que "(...) Tanto vulnera a lei aquele que inclui no campo de aplicação hipótese não contemplada como o que exclui caso por ela abrangido" (STF - HC 74183/SP, Rel. Min. MARCO AURÉLIO, DJ 21/2/97)

Por outro lado, penso que o risco de lesão grave ou de dificil reparação decorre da da execução da medida socioeducativa de internação, a qual, indiscutivelmente, reveste-se de caráter excepcional e deve reger-se pelo princípio da brevidade, nos termos do art. 121 do Estatuto da Criança e do Adolescente, por prazo superior ao determinado pela lei de regência, motivo pelo qual o tempo necessánio à instrução desta impetração tomaria inócua a decisão a ser proferida quando do julgamento do seu mérito, que se presume seguir na linha dos precedentes deste Superior Tribumal de Justiça (HC 42.754/SP, Rel. Min PAULO MEDINA. SEXTA TURMA, DJ de $1^{\circ} / 8 / 05 ;$ HC 41.384 RJ, Rel. Min. GILSON DIPP, Quinta Turma, DJ de 27/6/05; HC 34.251/SP, Rel. Min. LAURITA VAZ, Quinta Turma, DJ de 8/11/04).

Pelo exposto, defiro o pedido de liminar para que os pacientes sejam colocados em liberdade assistida até o julgamento do mérito da impetração. Intime-se.

Commique-se ao Juizo de Direito da $2^{\mathrm{x}}$ Vara de Cível e Criminal da Comarca de Camapuã/MS, remetendo cópia da presente decisão.

Devidamente instruidos, com cópia do docisum que aplicou a medids socioeducativa impuguada (fls. 23/27) e do acórdão atacado neste urit (fls. 55/58), dispenso as informações.

Encaminhem-5e o5 autos ao Ministério Prúblico Federal para parecer. Brasilia (DF), 10 de maio de 2007.

MINISTRO ARNALDO ESTEVES LIMA

Relator 


\section{QUADRO SISTEMATIZADO DE JURISPRUDÊNCIA}

\section{TRIBUNAL DE JUSTIÇA DE SÃO PAULO}

\begin{tabular}{|c|c|c|c|c|c|c|c|c|c|c|}
\hline & $\begin{array}{c}\text { Número do } \\
\text { processo }\end{array}$ & Natureza & $\begin{array}{c}\text { Data do } \\
\text { julgamento }\end{array}$ & Origem & $\begin{array}{c}\text { Autor/Apelante/ } \\
\text { Recorrente }\end{array}$ & $\begin{array}{l}\text { Réu/Apelados/ } \\
\text { Recorridos }\end{array}$ & $\begin{array}{c}\text { Vara/Câmar } \\
\mathbf{a}\end{array}$ & $\begin{array}{l}\text { Votação/ } \\
\text { Resultado }\end{array}$ & Relator & Ementa \\
\hline 1 & 13988712000 & $\begin{array}{c}\text { Apelação/Reclu } \\
\text { são }\end{array}$ & $23 / 10 / 2003$ & $\begin{array}{c}\text { V.C. (PROC. } \\
\text { H4/98) } \\
\text { Comarca de } \\
\text { Americana }\end{array}$ & $\begin{array}{c}\text { APELANTE } \\
\text { ALESSANDRO } \\
\text { FERREIRA DA } \\
\text { SILVA }\end{array}$ & $\begin{array}{l}\text { APELADO } \\
\text { MINISTÉRIO } \\
\text { PUBLICO }\end{array}$ & $\begin{array}{l}7^{\circ} \text { Câmara/ } \\
\text { Americana }\end{array}$ & $\begin{array}{l}\text { NEGARAM } \\
\text { PROVIMENT } \\
\text { O. V.U. }\end{array}$ & $\begin{array}{l}\text { Volney } \\
\text { Correa } \\
\text { Leite de } \\
\text { Moraes }\end{array}$ & 1 \\
\hline 2 & $\begin{array}{c}0005843- \\
86.2009 .8 .26 .0 \\
597\end{array}$ & $\begin{array}{l}\text { Reexame } \\
\text { Necessário }\end{array}$ & $25 / 07 / 2011$ & $\begin{array}{c}584386200982 \\
60597\end{array}$ & & & $\begin{array}{l}7^{\circ} \text { Câmara/ } \\
\text { Sertãozinho }\end{array}$ & $\begin{array}{l}\text { NEGARAM } \\
\text { PROVIMENT } \\
\text { O. V.U. }\end{array}$ & $\begin{array}{c}\text { Presidente } \\
\text { Da Seção } \\
\text { De Direito } \\
\text { Privado }\end{array}$ & 2 \\
\hline
\end{tabular}

\footnotetext{
${ }^{1}$ Vistos, relatados e discutidos estes autos de apelação - Reclusão número 1398871/2, da Comarca de Americana - 2- V.C. (PROC. H4/98), EM QUE É: APELANTE ALESSANDRO FERREIRA DA SILVA APELADO MINISTÉRIO PUBLICO ACORDAM, EM SÉTIMA CÂMARA DO TRIBUNAL DE ALÇADA CRIMINAL, PROFERIR A SEGUINTE DECISÃO: NEGARAM PROVIMENTO. V.U. NOS TERMOS DO VOTO DO RELATOR, EM ANEXO. PRESIDIU E PARTICIPOU DO JULGAMENTO O SR.JUIZ SOUZA NERY (REVISOR), PARTICIPANDO AINDA, O SR. JUIZ SALVADOR D'ANDRÉA (3. JUIZ).

${ }^{2}$ Ação civil pública. Reexame necessário. Instalação e manutenção de programa de acolhimento institucional destinado a crianças e adolescentes em situação de risco. Medida de proteção que se insere na política de atendimento instituída pelo Estatuto da Criança e do Adolescente e constitui prioridade social, de sorte a dar efetividade ao comando da Constituição Federal (art. 227).
} 
SUPERIOR TRIBUNAL DE JUSTIÇA

\begin{tabular}{|c|c|c|c|c|c|c|c|c|c|}
\hline & $\begin{array}{l}\text { Número } \\
\text { do } \\
\text { processo }\end{array}$ & Natureza & $\begin{array}{c}\text { Data do } \\
\text { julgament } \\
\text { o } \\
\end{array}$ & Origem & $\begin{array}{l}\text { Autor/Apelante/ } \\
\text { Recorrente }\end{array}$ & $\begin{array}{l}\text { Réu/Apelados/ } \\
\text { Recorridos }\end{array}$ & $\begin{array}{l}\text { Votação/ } \\
\text { Resultado }\end{array}$ & Relator & Ementa \\
\hline 1 & $\begin{array}{c}\mathrm{N}^{\mathrm{o}} \\
1.319 .70 \\
4\end{array}$ & $\begin{array}{l}\text { RECURSO } \\
\text { ESPECIAL }\end{array}$ & $\begin{array}{c}09 \text { de } \\
\text { outubro de } \\
2012\end{array}$ & $\begin{array}{c}\mathrm{RS} \\
(2012 / 007266 \\
0-6)\end{array}$ & $\begin{array}{l}\text { W DE O DOS S (MENOR) } \\
\text { REPR: A M DA C O }\end{array}$ & $\begin{array}{c}\text { MINISTÉRIO PÚBLICO } \\
\text { DO ESTADO DO RIO } \\
\text { GRANDE DO SUL }\end{array}$ & $\begin{array}{l}\text { Recurso especial } \\
\text { improvido. }\end{array}$ & $\begin{array}{l}\text { Ministro } \\
\text { SEBASTIÃ } \\
\text { O REIS } \\
\text { JÚNIOR }\end{array}$ & 3 \\
\hline 2 & $\begin{array}{c}\mathrm{N}^{\mathrm{o}} \\
224.583\end{array}$ & $\begin{array}{l}\text { HABEAS } \\
\text { CORPUS }\end{array}$ & $\begin{array}{c}30 \text { de } \\
\text { novembro } \\
\text { de } 2011\end{array}$ & $\begin{array}{c}\text { SP } \\
(2011 / 026950 \\
0-4)\end{array}$ & $\begin{array}{c}\text { CRISTINA SON - } \\
\text { DEFENSORA PÚBLICA E } \\
\text { OUTRO - S. D. A. } \\
\text { (INTERNADO) }\end{array}$ & $\begin{array}{c}\text { TRIBUNAL DE JUSTIÇA } \\
\text { DO ESTADO DE SÃO } \\
\text { PAULO }\end{array}$ & HC concedido & $\begin{array}{c}\text { MINISTRO } \\
\text { SEBASTIÃ } \\
\text { O REIS } \\
\text { JÚNIOR } \\
\end{array}$ & 4 \\
\hline 3 & $\begin{array}{c}\mathrm{N}^{\mathrm{o}} \\
114.859\end{array}$ & $\begin{array}{l}\text { HABEAS } \\
\text { CORPUS }\end{array}$ & $\begin{array}{c}23 \text { de } \\
\text { outubro de } \\
2008\end{array}$ & $\begin{array}{c}\text { DF } \\
(2008 / 019549 \\
8-6)\end{array}$ & $\begin{array}{c}\text { DEFENSORIA PÚBLICA } \\
\text { DO DISTRITO FEDERAL } \\
\text { ADVOGADO: LUIS } \\
\text { CLÁUDIO VAREJÃO DE } \\
\text { FREITAS - DEFENSOR } \\
\text { PÚBLICO } \\
\text { PACIENTE: L B DE L }\end{array}$ & $\begin{array}{c}\text { TRIBUNAL DE JUSTIÇA } \\
\text { DO DISTRITO } \\
\text { FEDERAL E DOS } \\
\text { TERRITÓRIOS }\end{array}$ & HC concedido & $\begin{array}{l}\text { MINISTRO } \\
\text { OG } \\
\text { FERNAND } \\
\text { ES }\end{array}$ & \\
\hline 4 & $\begin{array}{c}\mathrm{N}^{\mathrm{o}} \\
82.606\end{array}$ & $\begin{array}{l}\text { HABEAS } \\
\text { CORPUS }\end{array}$ & $\begin{array}{l}10 \text { de maio } \\
\text { de } 2007\end{array}$ & $\begin{array}{c}\text { MS } \\
(2007 / 010514 \\
0-1)\end{array}$ & $\begin{array}{c}\text { DEFENSORIA PÚBLICA } \\
\text { DO ESTADO DE MATO } \\
\text { GROSSO DO } \\
\text { SUL E ADV: CACILDA } \\
\text { KIMIKO NAKASHIMA - } \\
\text { DEFENSORA PÚBLICA } \\
\text { PACIENTE: J C R DA S } \\
\text { PACIENTE: R R DE L }\end{array}$ & $\begin{array}{c}\text { TRIBUNAL DE JUSTIÇA } \\
\text { DO ESTADO DE MATO } \\
\text { GROSSO DO } \\
\text { SUL }\end{array}$ & HC concedido & $\begin{array}{l}\text { MINISTRO } \\
\text { ARNALDO } \\
\text { ESTEVES } \\
\text { LIMA }\end{array}$ & \\
\hline
\end{tabular}

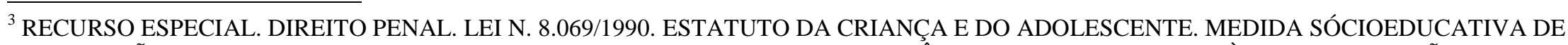
INTERNAÇÃO. ATO INFRACIONAL EQUIPARADO AO CRIME DE ESTUPRO. VIOLÊANCIA E GRAVE AMEAÇA À PESSOA. DECISÃO JUDICIAL FUNDAMENTADA. ACÓRDÃO A QUO EM CONSONÂNCIA COM A JURISPRUDÊNCIA DESTE TRIBUNAL. SÚMULA 83/STJ.

${ }^{4}$ HABEAS CORPUS. ECA. MEDIDA DE INTERNAÇÃO.

NECESSIDADE DE TRATAMENTO AMBULATORIAL. MEDIDA DE CARÁTER MERAMENTE RETRIBUTIVO. ILEGALIDADE. Ordem concedida para que a

paciente seja inserida na medida socioeducativa de liberdade assistida, associada ao acompanhamento ambulatorial psiquiátrico, psicopedagógico e familiar. 